\title{
A pluralidade do \\ conhecimento na saúde, na educação e na tecnologia
}

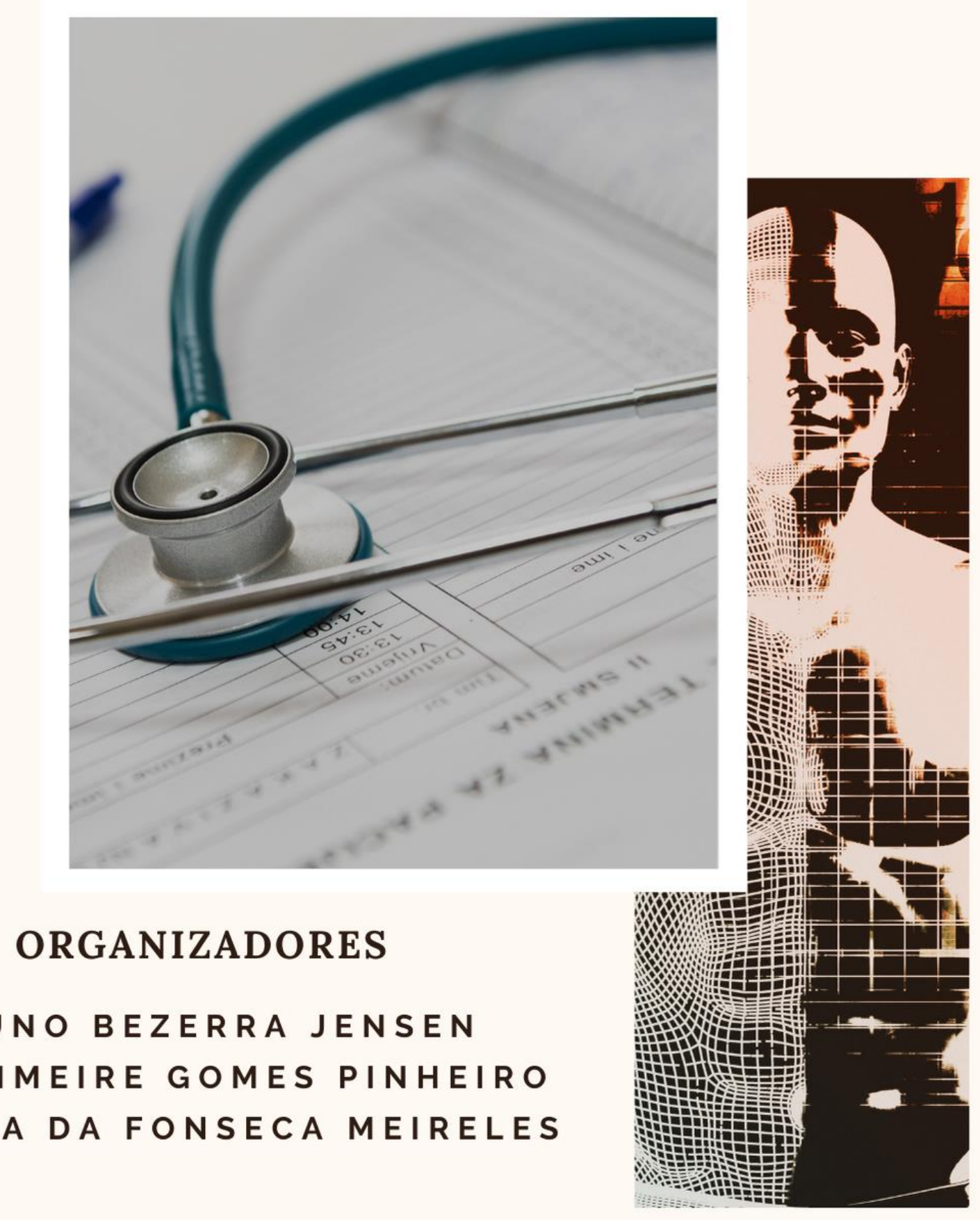

BRUNO BEZERRA JENSEN

FRANCIMEIRE GOMES PINHEIRO SABRINA DA FONSECA MEIRELES 
Bruno Bezerra Jensen

Francimeire Gomes Pinheiro

Sabrina da Fonseca Meireles

(Organizadores)

\section{A pluralidade do conhecimento na saúde, na educação e na tecnologia}

1a Edição

Belo Horizonte

Poisson

2021 
Editor Chefe: Dr. Darly Fernando Andrade

\section{Conselho Editorial}

Dra. Liliane Coelho da Rocha (Universidade do Estado do Amazonas - Escola Superior de Ciências da Saúde).

Profa. Dra. Alexandra Priscilla Tregue (Centro Universitário CEUNI-FAMETRO).

Profa. Dra. Antonia Maria Ramos Franco Pereira (Instituto Nacional de Pesquisas da Amazônia - INPA).

Dra. Claudia D. Comandolli Wyrepkowski (Secretaria de Estado da Saúde de Santa Catarina)

Profa. Dra. Fabiane Veloso Soares (Centro Universitário do Norte - UNINORTE)

Prof. Dr. Pedro Rauel Candido Domingos (Centro Universitário do Norte - UNINORTE)

\section{Comitê Científico}

Profa. Dra. Francimeire Gomes Pinheiro (Centro Universitário CEUNI-FAMETRO)

Prof. Dr. Bruno Bezerra Jensen (Instituto Nacional de Pesquisas da Amazônia - INPA)

Prof. Esp. Marcus Tulio Alves (Marinha do Brasil)

Profa. Me. Erika Silva (Centro Universitário CEUNI-FAMETRO)

Profa. Me. Sabrina da Fonseca Meireles (Instituto Nacional de Pesquisas da Amazônia - INPA)

Me. Thiago de Jesus Bacha (Instituto Nacional de Pesquisas da Amazônia - INPA)

Prof. Dr. Ricardo Wilson Aguiar da Cruz (Instituto de Tecnologia da Amazônia - UTAM/UEA)

Profa. Dra. Paula Figliuolo da Cruz Borges (Instituto Nacional de Pesquisas da Amazônia - INPA)

Dados Internacionais de Catalogação na Publicação (CIP)
$\begin{aligned} & \text { P737 } \\ & \text { A pluralidade do conhecimento na saúde, na educação e } \\ & \text { na tecnologia/ Organização: Bruno Bezerra Jensen, } \\ & \text { Francimeire Gomes Pinheiro, Sabrina da Fonseca } \\ & \text { Meireles - Belo Horizonte - MG: Poisson, } 2021 \\ & \text { Formato: PDF } \\ & \text { ISBN: 978-65-5866-129-0 } \\ & \text { DoI: 10.36229/978-65-5866-129-0 } \\ & \text { Modo de acesso: World Wide Web } \\ & \text { Inclui bibliografia } \\ & \text { 1. Saúde 2. Educação 3. Tecnologia I. JENSEN, } \\ & \text { Bruno Bezerra, II. PINHEIRO, Francimeire Gomes III. } \\ & \text { MEIRELES, Sabrina da Fonseca V. Título } \\ & \text { Sônia Márcia Soares de Moura - CRB 6/1896 }\end{aligned}$
podendo ser utilizado para fins comerciais e nem ser alterada.

O conteúdo dos artigos e seus dados em sua forma, correção e confiabilidade são de responsabilidade exclusiva dos seus respectivos autores 


\section{Comissão organizadora}

\section{Bruno Bezerra Jensen}

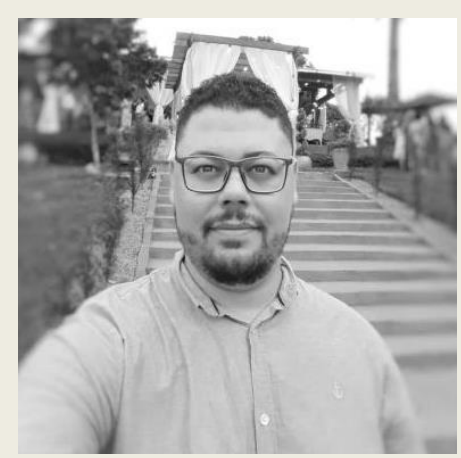

Possui graduação em Farmácia pela Faculdade Estácio do Amazonas, Especialização em Análises Clínicas pela Universidade Paulista (UNIP), Mestrado em Biotecnologia com ênfase em Saúde e Doutorado em Inovação Farmacêutica pela Universidade Federal do Amazonas (UFAM). Atua como Pesquisador visitante no Instituto Nacional de Pesquisas da Amazônia (INPA). Possui experiência no desenvolvimento de Produtos Biotecnológicos e Formulações Farmacêuticas para o tratamento alternativo/complementar de Doenças negligenciadas: com ênfase na Leishmaniose Tegumentar, avaliados por meio de ensaios pré-clínicos: in vitro e in vivo. Também apresenta experiência na área de Ensino Superior, iniciando a carreira Docente em 2018, ministrando disciplinas do ciclo básico ao específico: Citologia, Histologia, Bioquímica, Biotecnologia Farmacêutica, Farmacologia, Análises Toxicológicas, Tecnologia de Medicamentos e Cosméticos. Já atuou como Membro do Núcleo Docente Estruturante (NDE) dos cursos de Farmácia e Fisioterapia, Comissão de autorização e reconhecimento de curso junto ao MEC, Professor de Estágio (área de Saúde Pública, Alimentos e Análises Clínicas) e Coordenador do Curso de Graduação em Farmácia.

\section{Francimeire Gomes Pinheiro}

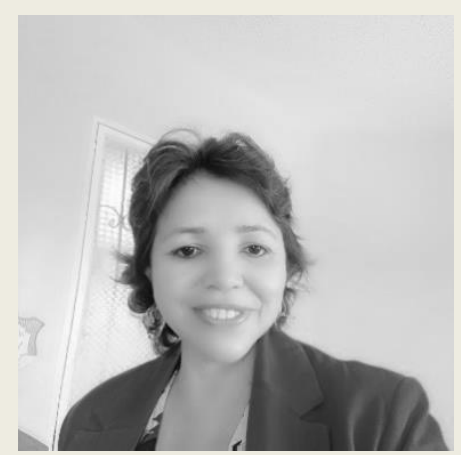

Possui graduação em Ciências Biológicas pela Universidade Federal do Amazonas (1998), Mestrado em Ciências biológicas com ênfase em Entomologia pelo Instituto Nacional de Pesquisas da Amazônia (2004) e Doutorado em Biotecnologia pela Universidade Federal do Amazonas (2013). Funcionaria Publica Federal do Instituto Nacional de Pesquisas da Amazônia (INPA). Realizou pesquisa na Fundação Oswaldo Cruz - Instituto Leônidas e Maria Deane e no Instituto de Ciências Biológicas da USP, Participou e participa de projetos de pesquisa envolvendo estudos com Protozoologia de Parasitos e Entomologia Médica. É Professora do Instituto Metropolitano de Ensino - IME, na qual participa do Núcleo Docente Estruturante (NDE) do curso de Enfermagem, além de ministrar nas disciplinas do curso de Farmácia, Odontologia, Biomedicina, Nutrição e Engenharia Ambiental, nesses cursos atua também na elaboração e execução de projetos científicos. 


\section{Sabrina da Fonseca Meireles}

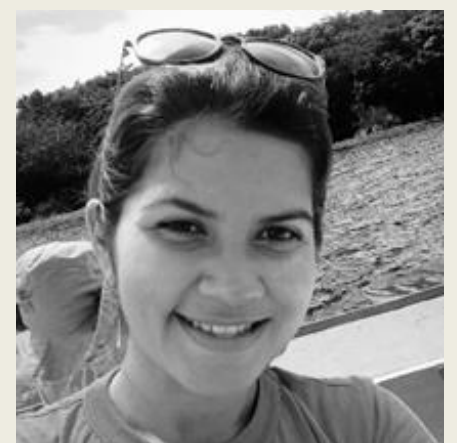

Graduada em Ciências Biológicas pela Universidade do Estado do Amazonas - UEA (2015), Mestre em Biotecnologia com ênfase em recursos agroflorestais pela Universidade Federal do Amazonas (2018) e Doutoranda em Genética, Conservação e Biologia Evolutiva no Instituto Nacional de Pesquisas da Amazônia - INPA. Tem experiência na área de Genética Animal, com Aedes aegypti e Ae. albopictus vetores de arboviroses, envolvendo estudos de expressão gênica, mutagênese e genotoxicidade; pesquisas sobre Anopheles vetores de plasmódios da malária e Mansonia, vetores de filariose linfática, envolvendo análises de citogenética clássica. Atualmente desenvolve pesquisas no Laboratório de Citogenética, Genômica e Evolução de Mosquitos e Microrganismos Etiológicos do INPA, na área de genética microbiana, a qual engloba o isolamento e identificação genômica e bioquímica de bactérias associadas ao Mansonia. Também possui experiência em docência no Ensino Básico (Fundamental e Médio) na Escola do Meio Ambiente e Clube de Ciências da UEA, e no ensino superior, ministrante de disciplinas de bases biológicas para os cursos de Enfermagem, Farmácia, Medicina Veterinária e Educação Física, no Centro Universitário do Norte - UNINORTE. 


\section{Prefácio}

No contexto da Organização Mundial de Saúde (OMS), a saúde não é simplesmente ausência de doença, mas sim, o envolvimento do bem-estar físico, mental e social. E quando tratamos sobre a Saúde, também se faz preciso discutir sobre educação, ambiente e tecnologias. Essa é a interação em que o indivíduo vem vivenciando nos ambientes familiares, educacionais e profissionais.

O engajamento de multiprofissionais envolvidos nas várias vertentes da saúde, da educação e da tecnologia nos direciona para um saber de pluralidades, e não somente excludente e individual. Os profissionais envolvidos em divulgar tais saberes vão das áreas da Farmácia, Ciências biológicas, Matemática, Nutrição, Engenharia, entre outras. Vale ressaltar quando um grupo de profissionais trabalha conjuntamente para a divulgação do conhecimento, possibilitarão diferentes abordagens de questões imprescindíveis à população.

A relação entre ensino e pesquisa proporciona caminhos revolucionários ao longo da trajetória acadêmica de um indivíduo, principalmente quando o transforma em um profissional crítico e reflexivo. Esse dinamismo normalmente pode ser observado quando é alcançada a etapa de elaboração do trabalho de conclusão de curso (TCC), pois, é nesse momento que o indivíduo se depara com a necessidade de escolher um tema intrínseco à sua área de formação e determinar o tipo de estudo que será realizado, como requisito para obtenção do tão sonhado diploma. É nesse contexto que os alunos da área da saúde vêm discutindo com mais frequência sobre a aplicação de recursos tecnológicos e técnicas investigativas para o ensino e pesquisa como instrumentos nas Ciências da Saúde.

Diante disso, é com grande satisfação que apresentamos esta obra, intitulada "A

\section{PLURALIDADE DO CONHECIMENTO NA SAÚDE, NA EDUCAÇÃO E NA TECNOLOGIA",} direcionada ao público acadêmico, com a organização de uma coletânea de capítulos teorizando assuntos com enfoque em Saúde. Os trabalhos estão distribuídos por temas, como, campos de atuação do profissional de saúde e sua inclusão em uma equipe multidisciplinar; educação e recursos alternativos; aplicação de técnicas experimentais e/ou laboratoriais; e sobre propriedade e evolução nutricional.

Bruno Bezerra Jensen

Prof. Dr. do Instituto Nacional de Pesquisas da Amazônia (INPA). Francimeire Gomes Pinheiro

Profa. Dra. do Centro Universitário CEUNI-FAMETRO Sabrina da Fonseca Meireles

Prof. Me. do Instituto Nacional de Pesquisas da Amazônia (INPA). 


\section{SUMÁRIO}

Capítulo 1: A matemática no cotidiano do profissional de sáude 10

Marcus Tulio Alves, Francimeire Gomes Pinheiro

DOI: 10.36229/978-65-5866-129-0.CAP.01

Capítulo 2: Metodologias alternativas para o ensino de genética molecular no ensino básico

Cosmo Araújo de Oliveira, Juliana Maria de Morais, Francimeire Gomes Pinheiro

DOI: 10.36229/978-65-5866-129-0.CAP.02

Capítulo 3: Educação em saúde para o controle de Aedes aegypti. 30

Paula Figliuolo da Cruz Borges, Thaís Nunes dos Santos, Renata Figliuolo da Cruz Tupinambá

DOI: 10.36229/978-65-5866-129-0.CAP.03

Capítulo 4: A formação do educador e os aspectos voltados para o exercício da docência no Ensino Superior. 40

Karine Garcez Mc Comb, Francimeire Gomes Pinheiro

DoI: 10.36229/978-65-5866-129-0.CAP.04

Capítulo 5: A importância da equipe multidisciplinar para administração de nutrientes por via parenteral em Unidade de Terapia Intensiva - UTI.

Deivany de Souza Lima, Francimeire Gomes Pinheiro, Bruno Bezerra Jensen

DOI: 10.36229/978-65-5866-129-0.CAP.05

Capítulo 6: Assistência de enfermagem humanizada na Unidade de Terapia Intensiva: Um estudo bibliográfico.

Karine Garcez Mc Comb, Francimeire Gomes Pinheiro

DOI: 10.36229/978-65-5866-129-0.CAP.06

Capítulo 7: Atuação multidisciplinar no aconselhamento genético em predisposição hereditária ao câncer .

Thiago de Jesus Bacha, Sabrina da Fonseca Meireles, Fernanda Teresa de Lima

DOI: 10.36229/978-65-5866-129-0.CAP.07

Capítulo 8: Qual é a importância do enfermeiro auditor para a melhoria da qualidade de assistência à saúde? 88

Karine Garcez Mc Comb, Sabrina da Fonseca Meireles, Francimeire Gomes Pinheiro

DoI: 10.36229/978-65-5866-129-0.CAP.08 


\section{SUMÁRIO}

Capítulo 9: 0 estudo das plantas alimentícias não convencionais no Brasil: Uma revisão sistemática.

Jamile da Silva Brito, Francimeire Gomes Pinheiro, Sabrina da Fonseca Meireles, Bruno Bezerra Jensen DOI: 10.36229/978-65-5866-129-0.CAP.09

Capítulo 10: Aspectos nutricionais e desempenho escolar de crianças e adolescentes com malária na Região Amazônica - Uma revisão sistemática

Sabrina da Fonseca Meireles, Grazielle Tayná Barbosa da Silva, Rubia Kezia Barroso da Cruz, Francimeire Gomes Pinheiro

DOI: $10.36229 / 978-65-5866-129-0 . C A P .10$

Capítulo 11: Avaliação do estado nutricional de uma frequentadora de acadêmica de atividade funcional: Relato de caso. 116

Marli Mendonça Pereira, Francimeire Gomes Pinheiro

DOI: $10.36229 / 978-65-5866-129-0 . C A P .11$

Capítulo 12: A relação entre gravidez e anemia no Brasil: uma revisão de literatura.. 126 Jéssica Lorena dos Santos Rocha, Sabrina da Fonseca Meireles, Francimeire Gomes Pinheiro DOI: $10.36229 / 978-65-5866-129-0 . C A P .12$

Capítulo 13: Alterações das papilas gustativas e o estado nutricional dos idosos 136 Monique Moldes da Silva, Francimeire Gomes Pinheiro DOI: $10.36229 / 978-65-5866-129-0 . C A P .13$

Capítulo 14: 0 processamento da polpa de açaí em uma feira-livre na cidade de ManausAM: Estudo de caso 150

Samuel Moreira Lima, Francimeire Gomes Pinheiro, Sabrina da Fonseca Meireles

DOI: $10.36229 / 978-65-5866-129-0 . C A P .14$

Capítulo 15: Modelo estimativo da oferta de curto prazo de óleo comestível usado para produção de biodiesel.

Ricardo Wilson Aguiar da Cruz, Paula Figliuolo da Cruz Borges

DOI: 10.36229/978-65-5866-129-0.CAP.15 


\section{SUMÁRIO}

Capítulo 16: Perfil microbiológico de placas de manipulação de alimentos, oriundas de uma Instituição de Ensino Superior de Manaus, Amazonas 169

Gabay Manuel Marques Reis Silva, Sabrina da Fonseca Meireles, Francimeire Gomes Pinheiro

DOI: $10.36229 / 978-65-5866-129-0 . C A P .16$

Capítulo 17: Análise bacteriológica de balaústres de ônibus utilizados no transporte público de Manaus.

Heraldo de Oliveira Alves, Liliane Coelho da Rocha, Sabrina da Fonseca Meireles, Francimeire Gomes Pinheiro

DOI: $10.36229 / 978-65-5866-129-0 . C A P .17$

Capítulo 18: Bactérias associadas ao intestino do mosquito Aedes aegypti (Diptera: Culicidae): Uma revisão sobre a diversidade e função

Sabrina da Fonseca Meireles, Ricardo de Melo Katak, Míriam Silva Rafael

DOI: $10.36229 / 978-65-5866-129-0 . C A P .18$

Capítulo 19: Deteç̧ão de criadouros de Aedes aegypti e Aedes Albopictus (Diptera: Culicidae) em cemitério de Manaus, Amazonas

Fabiane Monteiro da Silva, Luiz Henrique Fonseca dos Santos, Gabay Manuel Marques Reis da Silva, Sabrina da Fonseca Meireles, Francimeire Gomes Pinheiro

DOI: $10.36229 / 978-65-5866-129-0 . C A P .19$

Capítulo 20: Construção de um banco de cDNA de Aedes albopictus (Diptera: Culicidae) contaminado com semissintéticos do dilapiol 217

Sabrina da Fonseca Meireles, Ana Cristina da Silva Pinto, Míriam Silva Rafael

DOI: $10.36229 / 978-65-5866-129-0 . C A P .20$

Capítulo 21: Avaliação de dois métodos de extração de rna total de Aedes aegypti Linnaeus, 1762 (Diptera: Dulicidae).

Joaquim Ferreira do Nascimento Neto, Sabrina da Fonseca Meireles, Thamiles das Chagas Gonçalves, Míriam Silva Rafael, Rosemary Aparecida Roque, Wanderli Pedro Tadei

DOI: $10.36229 / 978-65-5866-129-0 . C A P .21$ 


\section{Capítulo 1}

\section{A matemática no cotidiano do profissional de sáude}

\section{Marcus Tulio Alves \\ Francimeire Gomes Pinheiro}

Resumo: 0 ensino da matemática apresenta-se estruturado na escola da seguinte forma: ciência autônoma e abstrata, visando ensinamentos sem um propósito de aplicação imediata na realidade. A outra seria como prática ou exatamente como instrumento de desenvolvimento de uma ação para resolução de problemas. Ao direcionarmos a matemática para a área da saúde, observa-se que essa disciplina é de extrema importância para esses profissionais, porque é através do domínio de cálculos matemáticos básicos que o profissional resolve problemas que envolvem a administração de medicamentos, contagem de calorias, relação do Índice de Massa Corpórea (IMC) com absorção de alimentos. Diante do exposto o objetivo desse trabalho bibliográfico é descrever como a matemática é utilizada pelos profissionais da saúde e quais são esses profissionais e os cálculos matemáticos que realizam no decorrer de suas atividades. A metodologia empregada foi uma revisão da literatura objetivando descrever uma síntese de estudos pesquisados em conclusões gerais sobre a utilização de conceitos matemáticos nesta área de atuação. Nesta revisão foram utilizadas publicações a abordam a matemática na saúde, modelagem matemática na saúde, cálculos matemáticos na saúde. Dentre as áreas da saúde (Nutrição, Medicina, Medicina Veterinária, Farmácia e Educação Física), a Enfermagem é a que apresenta mais trabalhos envolvendo a matemática, pois para esses profissionais se faz presente na preparação de medicamentos, na infusão, no monitoramento do equilíbrio de fluidos, sinais vitais do paciente e interpretação de dados laboratoriais. No estudo, verificou-se que as habilidades matemáticas na área da saúde é fato importantíssimo, pois qualquer cálculo errado pode levar a erros que colocam em risco a saúde dos pacientes.

Palavras-chave: Modelagem matemática, Saberes da matemática, Habilidade na matemática 


\section{INTRODUÇÃO}

O progresso humano está entrelaçado com a descoberta da matemática, pois em certas obras literárias afirmam que está disciplina está intimamente enlaçada com a história da civilização (SAITO, 2012; LOPES e FERREIRA, 2012). De acordo com Lopes e Ferreira (2012), os saberes da matemática e a civilização humana não evoluíram isolados, a relação do desenvolvimento social e econômico e a matemática é um elo para obter a compreensão dos conhecimentos matemáticos atuais.

Em relação a história da matemática no Brasil, poucos são os relatos dessa disciplina em solo brasileiro, primeiramente por ser uma Colônia, não existia nenhum interesse por parte dos colonizadores no ensino da matemática, muito menos estrutura, bem sabe que a matemática ao longo da historia brasileira ficou dividida assim, matemática jesuíta; militar; positivista e a matemática institucionalizada (MENEZES e CAVALCANTI, 2006; BRITO, 2007).

0 ensino da matemática apresenta-se estruturado na escola da seguinte forma: ciência autônoma e abstrata, visando ensinamentos sem um propósito de aplicação imediata na realidade. A outra seria como prática ou exatamente como instrumento de desenvolvimento de uma ação para resolução de problemas (KLUG e RAMOS, 2013).

0 que se vivência em aulas de matemática são discentes abnegativos, desatentos não visualizam a aplicabilidade na matemática em seu dia-a-dia, pois afirmam que aprender determinados conceitos matemáticos não irão lhe ajudar em seu cotidiano (LARA, 2011).

De acordo com D’AMBRÓSIO (1986, p115) em sua obra literária, no qual afirmou "a matemática deve servir à melhoria da qualidade de vida humana". É necessário mostrar aos alunos que eles também podem ser matemáticos, e que, ao enfrentar seus desafios, podem também criar sua própria matemática.

0 conhecimento da matemática é de extrema importância em nosso cotidiano, seja em estudos de pesquisas, no comércio, em análises de dados estatísticos, na construção da declaração do imposto de renda ou até mesmo no orçamento de uma família.

Mas se levarmos a matemática para a área da saúde, notaremos que essa disciplina é de extrema importância para esses profissionais, porque é através do domínio de cálculos matemáticos básicos que o futuro profissional resolverá problemas que envolvem a administração de medicamentos, contagem de calorias, relação do Índice de Massa Corpórea (IMC) com absorção de alimentos, esses profissionais têm, muitas vezes, a vida dos pacientes em suas mãos e devem desempenhar seu trabalho com responsabilidade e competência.

Portanto, o professor enquanto pesquisador tem, como responsabilidade, favorecer $o$ estabelecimento de relações entre a matemática acadêmica e o conhecimento prévio dos alunos, para que os mesmos possam perceber a presença da matemática nas atividades que eles realizam diariamente.

Diante do exposto, o objetivo do trabalho foi demonstrar como a matemática é utilizada pelos profissionais da saúde, além de apresentar quais são esses profissionais e os cálculos matemáticos que fazem uso. 


\section{REFERENCIAL TEORICO}

\subsection{A HISTÓRIA DA MATEMÁTICA}

O progresso humano está entrelaçado com a descoberta da matemática, pois em certas obras literárias afirmam que está disciplina está intimamente enlaçada com a história da civilização (SAITO, 2012; LOPES e FERREIRA, 2012). Relata-se que a matemática surgiu muito antes da escrita, e isto se deu na Mesopotâmia (3000 a.C.), na qual foram encontradas cerca de meio milhão de tabulas que dão citação principalmente sobre: resolução de problemas práticos com destaque a cálculos aritméticos com emprego em primeiro lugar na agricultura (MONRUE, 1983; JUNIOR, 2010). De acordo com Junior (2010), os grandes achados matemáticos foram produzidos na Babilônia, sendo assim a matemática babilônica é considerada única, não sendo alcançada por nenhuma outra civilização.

De acordo com Lopes e Ferreira (2012), os saberes da matemática e a civilização humana não evoluíram isolados, a relação do desenvolvimento social e econômico e a matemática é um elo para obter a compreensão dos conhecimentos matemáticos atuais.

Em relação a história da matemática no Brasil, poucos são os relatos dessa disciplina em solo brasileiro, primeiramente por ser uma Colônia, não existia nenhum interesse por parte dos colonizadores no ensino da matemática, muito menos estrutura, bem sabe que a matemática ao longo da história brasileira ficou dividida assim, matemática jesuíta; militar; positivista e a matemática institucionalizada (MENEZES e CAVALCANTI, 2006; BRITO, 2007).

\subsection{A MATEMÁTICA NAS ESCOLAS}

O ensino da matemática apresenta-se estruturado na escola da seguinte forma: ciência autônoma e abstrata, visando ensinamentos sem um propósito de aplicação imediata na realidade. A outra seria como prática ou exatamente como instrumento de desenvolvimento de uma ação para resolução de problemas (KLUG e RAMOS, 2013).

O que se vivência em aulas de matemática são discentes abnegativos, desatentos, não visualizam a aplicabilidade na matemática em seu dia-a-dia, pois afirmam que aprender determinados conceitos matemáticos não irão lhe ajudar em seu cotidiano (LARA, 2011).

De acordo com D’Ambrosio (1986, 115p.) em sua obra literária, no qual afirmou "a matemática deve servir à melhoria da qualidade de vida humana". É necessário mostrar aos alunos que eles também podem ser matemáticos, e que, ao enfrentar seus desafios, podem também criar sua própria matemática.

0 professor que ministra matemática para cursos da área da saúde vem exercendo grande responsabilidade, pois esse profissional da saúde usará os cálculos matemáticos para administrar medicamentos, formular dietas e até aplicar exercícios físicos, entre outras atividades (ANDRADE e SAMPAIO, 2002). Portanto, o professor enquanto pesquisador tem, como responsabilidade, favorecer o estabelecimento de relações entre a matemática acadêmica e o conhecimento prévio dos alunos, para que os mesmos possam perceber a presença da matemática nas atividades que eles realizam diariamente (KNIJNIK, 1993). 


\section{MATÉRIAS E MÉTODOS}

Tratou-se de um estudo de revisão bibliográfica de caráter descritivo, exploratório, com desenho qualitativo, essa modalidade de pesquisa inclui material impresso, como livros, revistas, jornais, teses, dissertações e anais de eventos científicos. A metodologia empregada foi revisão da literatura, a qual permitiu a síntese de múltiplos estudos publicados em conclusões gerais a respeito de particular área de estudo. Possibilita a inclusão simultânea de pesquisa experimental e quase experimental proporcionando uma compreensão mais completa do tema de interesse (GIL, 2010).

Nesta revisão foram utilizados publicações encontradas nas bases de dados, LILACS (Literatura Latino Americana e de Caribe em Ciência da Saúde), SciELO (Scientific Electronic Library Online), REBEn (Revista Brasileira de Enfermagem) e a BVS (Biblioteca Virtual em Saúde), do qual foram utilizados os seguintes descritores: A matemática na saúde, modelagem matemática na saúde, cálculos matemáticos na saúde. O período de coleta dos dados foi de três meses (março, abril e maio) do ano de 2018.

\section{RESULTADOS E DISCUSSÃO}

O professor que ministra matemática para cursos da área da saúde vem exercendo grande responsabilidade, pois esse profissional da saúde usará os cálculos matemáticos para administrar medicamentos, formular dietas e até aplicar exercícios físicos, entre outras atividades (ANDRADE e SAMPAIO, 2002).

Estudos com intuito de demonstrar o uso da matemática pelos profissionais da saúde advieram por Perlstein et al. (1979), quando avaliaram os erros na administração de medicamentos em neonatais em um hospital pediátrico nos Estados Unidos, e na mesma linha de pesquisa Koren; Barzilay; Modan, (1983) em Israel. Na Europa, o emprego da matemática no desempenho da administração de medicamentos por enfermeiros foram destacados por Pirie, 1987; Hutton, 1998; Hilton, 1999; Wilson, 2003. Nesse continente o trabalho que merece destaque também foi de Grandell-Niemi et al. (2006), no qual investigaram as reais habilidades matemáticas dos enfermeiros e estudantes de enfermagem na Finlândia. Na região da Turquia foi de Çinar; Akunduran; Dogan, (2006).

No Brasil, trabalho pioneiro com essa temática foi de Andrade e Sampaio (2002), no qual apresentaram as contribuições para o estudo de diluição de medicamentos dentro de uma abordagem contextualizada da matemática.

No ano de (2013), Kluy e Ramos avaliaram os saberes de matemática que são utilizados pelos técnicos da enfermagem; e Xavier (2013), investigou o processo formativo do enfermeiro docente, em especial os currículos e as práticas pedagógicas no que se refere ao ensino e a aprendizagem da Matemática no contexto da Enfermagem.

Em outros cursos da saúde encontramos a Matemática, como os de Zorzella, Willers, Müller, (2013) na área da Medicina Veterinária; Siqueira et al., (2016) na Farmácia; Pereira, Melo, Bisognin, (2014) e Almeida et al., (2016) na nutrição e na área da Medicina com o trabalho recente de Sacilotto (2018), conforme demonstrado na tabela 1. 
Tabela 1 - Distribuição das literaturas produzidas no Brasil sobre Matemática na Saúde

\begin{tabular}{|c|c|c|c|}
\hline $\begin{array}{c}\text { Autor (res)/ } \\
\text { Ano }\end{array}$ & Título do artigo & Objetivo & $\begin{array}{c}\text { Área da } \\
\text { saúde }\end{array}$ \\
\hline $\begin{array}{l}\text { Andrade; } \\
\text { Sampaio, } \\
2002\end{array}$ & $\begin{array}{l}\text { Fundamentos matemáticos } \\
\text { para o Curso Técnico em } \\
\text { Enfermagem. }\end{array}$ & $\begin{array}{l}\text { Apresentar contribuições para o estudo } \\
\text { de diluição de medicamentos dentro de } \\
\text { uma abordagem contextualizada da } \\
\text { matemática. }\end{array}$ & Enfermagem \\
\hline $\begin{array}{l}\text { Kluy e } \\
\text { Ramos, } 2013\end{array}$ & $\begin{array}{l}\text { Saberes de } \text { Matemática } \\
\text { utilizados por técnicos de } \\
\text { enfermagem em sua prática } \\
\text { profissional. }\end{array}$ & $\begin{array}{l}\text { Conhecer os saberes de matemática que } \\
\text { são utilizados pelos técnicos da } \\
\text { enfermagem }\end{array}$ & Enfermagem \\
\hline Xavier, 2013 & $\begin{array}{l}\text { A educação matemática e o } \\
\text { currículo do enfermeiro } \\
\text { docente: dilemas e desafios. }\end{array}$ & $\begin{array}{l}\text { Investigar o processo formativo do } \\
\text { enfermeiro docente, em especial os } \\
\text { currículos e as práticas pedagógicas no } \\
\text { que se refere ao ensino e a aprendizagem } \\
\text { da Matemática no contexto da } \\
\text { Enfermagem. }\end{array}$ & Enfermagem \\
\hline $\begin{array}{l}\text { Silva et al., } \\
2009\end{array}$ & $\begin{array}{l}\text { Multidisciplinaridade na } \\
\text { prática: a relação entre } \\
\text { educação física e matemática } \\
\text { e suas colaborações mútuas } \\
\text { no desenvolvimento } \\
\text { cognitivo de escolares da } \\
\text { educação infantil. }\end{array}$ & $\begin{array}{l}\text { Verificar quais atividades motoras estão } \\
\text { mais ligadas a aspectos cognitivos com o } \\
\text { aprendizado da matemática. }\end{array}$ & $\begin{array}{l}\text { Educação } \\
\text { Física }\end{array}$ \\
\hline $\begin{array}{l}\text { Pereira; } \\
\text { Melo; } \\
\text { Bisognin, } \\
2014\end{array}$ & $\begin{array}{l}\text { Explorando o índice de massa } \\
\text { corporal por meio da } \\
\text { modelagem matemática }\end{array}$ & $\begin{array}{l}\text { Explorar modelos matemáticos a partir } \\
\text { de uma notícia do jornal local, que } \\
\text { informa sobre o número de brasileiros } \\
\text { que estão acima do peso ideal. }\end{array}$ & Nutrição \\
\hline $\begin{array}{ll}\text { Almeida } & \text { et } \\
\text { al., } 2016\end{array}$ & $\begin{array}{l}\text { Linha de fronteira e chance } \\
\text { matemática na determinação } \\
\text { do estado nutricional de } \\
\text { pitaia }\end{array}$ & $\begin{array}{l}\text { Avaliar através dos métodos linha de } \\
\text { fronteira e chance matemática, o estado } \\
\text { nutricional de pitaias submetidas a } \\
\text { combinações de doses crescentes de } \\
\text { nitrogênio-potássio (N-K) e fósforo-zinco } \\
\text { (P-Zn). }\end{array}$ & Nutrição \\
\hline $\begin{array}{ll}\text { Siqueira } & \text { et } \\
\text { al., } 2016 & \end{array}$ & $\begin{array}{l}\text { Importância do ensino de } \\
\text { matemática para estudantes } \\
\text { do curso de graduação em } \\
\text { farmácia. }\end{array}$ & $\begin{array}{l}\text { Promover a discussão sobre a } \\
\text { importância do ensino de matemática } \\
\text { para os estudantes de farmácia }\end{array}$ & Farmácia \\
\hline $\begin{array}{l}\text { Zorzella; } \\
\text { Willers; } \\
\text { Müller, } 2013 \\
\end{array}$ & $\begin{array}{l}\text { A relevância da modelagem } \\
\text { matemática e sua aplicação } \\
\text { na medicina veterinária }\end{array}$ & $\begin{array}{l}\text { Relacionar à área de Modelagem } \\
\text { Matemática e suas aplicações na } \\
\text { Medicina Veterinária. }\end{array}$ & $\begin{array}{l}\text { Medicina } \\
\text { Veterinária }\end{array}$ \\
\hline $\begin{array}{l}\text { Sacilotto, } \\
2018\end{array}$ & $\begin{array}{l}\text { Análise prognóstica do câncer } \\
\text { de rim através da teoria de } \\
\text { conjuntos Fuzzy }\end{array}$ & $\begin{array}{l}\text { Apresentar a construção de dois modelos } \\
\text { matemáticos desenvolvidos para } \\
\text { predizer os riscos de metástase e de } \\
\text { morte em pacientes portadores de } \\
\text { câncer nos rins }\end{array}$ & Medicina \\
\hline
\end{tabular}

Dentre as áreas da saúde (Nutrição, Medicina, Medicina Veterinária, Farmácia e Educação Física), a Enfermagem é a que apresenta mais trabalhos envolvendo a matemática, pois segundo Hoyles; Noss; Pozzi (2001), a matemática é onipresente na prática de enfermagem na preparação de medicamentos, na infusão, no monitoramento do equilíbrio de fluidos, sinais vitais do paciente e interpretação de dados laboratoriais. De acordo com Andrade e Sampaio (2002), os cálculos matemáticos precisos são uma habilidade crítica que os enfermeiros devem demonstrar para administrar medicamentos com segurança. 
No entanto, problemas ocorrem com esses profissionais em relação à Matemática, como a deficiência no desempenho de habilidades matemáticas, como por exemplo, domínio nas operações básicas da matemática, o qual foi observado por Xavier (2013), que concluiu em seu trabalho, que tais habilidades devem ser um dos requisitos de admissão para esses profissionais. Espera-se que os programas de enfermagem preparem esses futuros profissionais, para que possam ter a capacidade de realizar com segurança e precisão cálculos de medicação e dosagem (WRIGHT, 2008).

Em relação a nutrição e a matemática podemos observá-las na hora de montar o plano alimentar de cada um. Ou seja, cada pessoa necessita de uma quantidade de calorias e nutrientes como: carboidratos, proteínas, lipídios, vitaminas e sais minerais. Nenhuma dieta pode ser igual à outra. 0 valor calórico total é exato para aquela pessoa que esta sendo avaliada, seja para ganho ou perda de peso como também para qualquer outra patologia relacionada à alimentação (PEREIRA; MELO; BISOGNIN, 2014 e ALMEIDA et al., 2016).

Para Almeida; Tereza; Hatanaka (2017), a matemática além de ser uma importante ferramenta no calculo de dietas e necessidades nutricionais, a mesma tem sido uma aliada nas outras áreas de atuação do profissional nutricionista, a saber: participação no cálculo de dietas orais, enterais e principalmente parenterais. Também é utilizada na avaliação nutricional, calculando o IMC, nas pregas cutâneas, circunferências e estimativas de necessidades nutricionais e calcular calorias também só é possível com o uso da matemática.

Na Medicina Veterinária, a matemática vem auxiliando em pesquisas genéticas (melhoramento de espécies), contribuindo com a otimização da produção pecuária, no cálculo da frequência cardíaca ou respiratória de um animal, permitindo que se tenha um diagnóstico preciso sobre o estado em que este se encontra, aumentando as possibilidades de se obter êxito no tratamento de algum distúrbio fisiológico (ZORZELLA; WILLERS; MULLER, 2013).

Na Farmácia a matemática é uma ciência essencial para a resolução de problemas presentes em diversas situações de trabalho do farmacêutico (diluições de substrato, polarímetros, cromatógrafos, titulação, resistência de comprimidos, análise calorimétrica exploratória diferencial, concentrações em soluções e pH, concentração em sólidos, interpretação de gráficos, relação entre excipientes e ativos, entre outras) e também na vida acadêmica dos alunos (SIQUEIRA et al., 2016).

Os cálculos matemáticos utilizados pelos profissionais da saúde vão além das operações básicas, como no caso da Estatística, que é uma parte da Matemática Aplicada que fornece métodos para a coleta, organização, descrição, análise e interpretação de dados, permitindo a utilização dos mesmos na tomada de decisões, muito utilizada pelos epidemiologistas para evidenciar o surto de uma doença (BARATA, 2010).

Os profissionais da saúde fazem uso da matemática na diluição e fracionamento de doses: unidades principais de massa e capacidade (grama, miligrama, micrograma, litro, mililitro e microlitro). Além da notação Científica: Potência em base 10, entre outros cálculos. É de certo que o estudo da matemática no trabalho fornece um cenário particularmente frutífero para iluminar questões fundamentais sobre a construção de significados matemáticos em geral 


\section{CONCLUSÃO}

Em virtude dos fatos mencionados, a Matemática que tem raízes nas obrigações de contar e medir, na atualidade assume dimensões mais complexas como explanar a natureza, os fenômenos técnicos, sociais e econômicos. Na atualidade a característica mais pertinente da atividade profissional do professor é a mediação entre o aluno e o seu direcionamento social na sociedade, ensinar matemática tem sido, frequentemente, tarefa difícil. Às dificuldades próprias, somam-se as decorrentes de uma visão distorcida da matéria, estabelecida, muitas vezes, desde os primeiros contatos.

À área de saúde caracteriza-se como amplo campo de noção para a contextualização da matemática. É grande a responsabilidade do professor de matemática para os cursos nesta área, pois é através do domínio de cálculos matemáticos básicos que o futuro profissional resolverá problemas que envolvem a dinâmica fisiológica do ser humano. Estes profissionais têm, muitas vezes, a vida em suas mãos e devem desempenhar seu trabalho com responsabilidade e competência.

No estudo, verificou-se que as habilidades matemáticas na área da saúde é fato importantíssimo, pois qualquer cálculo incorreto pode ocasionar erros que podem por em risco a vida dos pacientes. Observa-se que os cálculos matemáticos são empregados em várias áreas da saúde à saber: nutrição, medicina veterinária, educação física, farmácia, medicina, mas em particular na enfermagem. Estudos demonstraram que se torna pertinente as habilidades matemática para os técnicos de enfermagem e enfermeiros e pondo em cheque-mate esses profissionais em relação aos saberes da matemática.

Com tudo, o desafio é elaborar propostas que possibilitem ao estudante aprender matemática de um modo melhor em uma perspectiva mais critica, entendendo distintas maneiras de matematizar e abarcando as etapas percorridas na criação de determinado conceito ou modelo matemático. Essa percepção servirá como suporte para a geração do seu próprio conhecimento.

Consoante a tudo o que foi mencionado pode-se inferir que a matemática tem se tornado fundamental nos diversos campos de atuação do profissional da saúde seja ele da área de clinica, produção, educação, vigilância ou atenção básica. 


\section{REFERÊNCIA}

ALMEIDA, C.A.; TEREZA, B.C.; HATANAKA, J.F.H. Quantificando as calorias dos alimentos: uma atividade Interdisciplinar entre ciências e matemática. In: VI SEMATED - Semana da Matemática e Educação Tendências em Educação Matemática. Araraquara, 2017.

ALMEIDA, E.I.B. et al. Linha de fronteira e chance matemática na determinação do estado nutricional de pitaia. Revista Ciência Agronômica, v. 47, n. 4, p. 744-754, 2016.

ANDRADE, R. S. SAMPAIO, M. E. C. S. Fundamentos matemáticos para o Curso Técnico em Enfermagem. In: XXV Congresso de matemática aplicada e computacional. Curitiba, Anais. Curitiba, $2002 . \quad$ DBMAC, Disponível <http://www.sbmac.org.br/eventos/cnmac/cd_xxv_cnmac/cnmac/20.pdf>. Acesso em: 25 de abril de 2018.

BARATA, Rita Barradas. Epidemiologia vs. Estatística: a velha contenda entre racionalismo e empirismo. Caderno de Saúde Pública, v. 26, n. 4, p. 667, 2010 . .

ÇINAR, N.; AKUNDURAN, F.; DOGAN, A. Mathematical skills of the nursing and midwifery students of Sakarya University school of healht sciences. Revista Eletrônica de Enfermagem.; v.8(2), p.174-84. 2006

DA SILVA, C.M. M. et al. Multidisciplinaridade na prática: a relação entre educação física e matemática e suas colaborações mútuas no desenvolvimento cognitivo de escolares da educação infantil. Pensar a Prática, v.12, n.2. 2009. Acesso em: 07 maio 2018.

D’AMBRÓSIO, U.. Da realidade à ação — reflexões sobre educação e matemática. São Paulo, SUMMUS/UNICAMP, 115p, 1986.

GIL, A.C. Como elaborar projetos de pesquisa; ed. 5. Atlas. São Paulo, 2010.

GRANDELL-NIEMI, H.; HUPLI, M.; PUUKKA, P.; LEINO-KILPI, H. Finnish nurses' and nursing students' mathematical skills. Nurse Education Today, v.26, p.151-161. 2006.

HILTON, D.E. Considering academic qualification in mathematics as an entry requirement for a diploma in nursing programme. Nurse Education Today, v19, p. 543547. 1999.

HOYLES, C.; NOSS, R.; POZZI, S. Proportional Reasoning in Nursing Practice. Journal for Research in Mathematics Education, v. 32, n 1, p. 4-27. 2001.

HUTTON, B.M. Do school qualifications predict competence in nursing calculations?. Nurse Education Today, v. 18 p. 25-31. 1998.

KLUG, D.; RAMOS, M. G. Saberes de Matemática utilizados por técnicos de enfermagem em sua prática profissional. Revemat. Florianopolis (SC), v. 08, n. 1, p. 119-137, 2013.

KOREN, G.; BARZILAY, Z.; MODAN, M. Errors in computing drug doses. Canadian Medical Association Journal. V. 109. 1983.

LARA, I. C. M. Jogando com a Matemática do $6^{\circ}$ ao $9^{\circ}$ ano. 4. ed. São Paulo: Rêspel, 2011. 
MENEZES, J. E.; CAVALCANTI, Z. S. L. O Movimento da Educação Matemática no Brasil nos Últimos Dois Séculos: influências e diretrizes. In Anais do SIPEMAT. Recife, Programa de Pós-Graduação em Educação - Centro de Educação - Universidade Federal de Pernambuco, 11p, 2006.

PERLSTEIN, P. et al. Errors in drug computations during newborn intensive care. American Journal of Diseases of Children 133:375-379. 1979.

PEREIRA, C.C.; MELO, C.B.S.; BISOGNIN, E. Explorando o índice de massa corporal por meio da modelagem matemática. In: XX EREMAT - Encontro Regional de Estudantes de Matemática da Região Sul Fundação Universidade Federal do Pampa (UNIPAMPA), Bagé. 13-16. 2014.

PIRIE, S. Nurses and Mathematics. Deficiencies in Basic Mathematical Skills among Nurses. Development and Evaluation of Methods of Detection and Treatment. Royal College of Nursing, London. 1987.

SACILOTTO, C. Análise prognóstica do câncer de rim através da teoria de conjuntos Fuzzy. Proceeding Series of the Brazilian Society of Applied and Computational Mathematics, v. 6, n. 1, 2018.

SAITO, F. Possíveis Fontes para a história da Matemática: explorando os tratados que versam sobre construção e uso de instrumentos "matemáticos" do século XVI. Disponível em:<http://www.sbhc.org.br/resources/anais/10/1345009925_ARQUIVO_SaitoFumika zu.pdf >. Acesso em: 10 de abril de 2018.

SIQUEIRA, A.C. et al. Importância do ensino de matemática para estudantes do curso de graduação em Farmácia. In: XII Encontro Nacional de Educação Matemática. São Paulo. 2016

WILSON, A. Nurses' maths: researching a practical approach. Nursing Standard, v. 17 p 33-36. 2003.

WRIGHT, K. Drug calculations part 1: A critique of the formula used by nurses. Nursing Standard, 22, 40-42. 2008.

XAVIER, C.M.S. A Educação matemática e o currículo do enfermeiro docente: dilemas e desafios. In: Anais do XI Encontro Nacional de Educação Matemática. Paraná. 2013.

ZORZELLA, M. D.; WILLERS, S.C.A.W.; MULLER, D.C.M. A relevância da modelagem matemática e sua aplicação na medicina veterinária. Relatório técnico-científico. In: XIV Jornada de Extensão. 2013. 


\section{Capítulo 2}

Metodologias alternativas para o ensino de genética molecular no ensino básico

\section{Cosmo Araújo de Oliveira}

Juliana Maria de Morais

Francimeire Gomes Pinheiro

Resumo: Docentes do ensino superior constataram que a maioria dos discentes vem do ensino básico com muita deficiência no conhecimento de genética. A proposta desse estudo foi identificar metodologias alternativas para ensino de genética molecular na primeira série do ensino médio. Ainda é notório que diversos docentes, mesmo sabendo a eficácia das metodologias alternativas já testadas, ainda utilizam métodos tradicionais para ensinar seus alunos. Para que o aluno possa criar um interesse pelo assunto ministrado, é necessário ter mecanismos para manter nesse aluno o máximo de atenção e despertar nele o desejo de ter conhecimento dentro do assunto abordado, uma vez que hoje se disponibiliza de vários recursos entre eles atividades lúdicas, júri simulado e outros. No presente trabalho foram utilizadas duas metodologias distintas para dois tópicos voltados para o conteúdo relacionado à genética molecular em duas turmas distintas da primeira série do ensino médio da Escola Estadual Engenheiro Artur Soares Amorim. Dos alunos que participaram da pesquisa, 33 (Turma A) foram avaliados pela metodologia 1 , onde $24,24 \%$ dos alunos obtiveram notas abaixo da média e $75,76 \%$ obtiveram nota acima de média. Já metodologia 2 (Turma B), 44,44\% dos alunos tiveram notas abaixo da média e 55,56\% tiveram acima da média. De acordo com as metodologias testadas, concluiu-se que, se o docente aplicar a metodologia alternativa diferente do método tradicional, ainda que o tema proposto seja de difícil compreensão, o discente terá mais facilidade de assimilar o conteúdo exposto.

Palavras-Chave: Teorias da aprendizagem, Ensino-aprendizagem, Cognitivismo 


\section{INTRODUCCÃO}

A dificuldade de compreensão dos conteúdos de Biologia tem instigado cada vez mais os docentes a buscarem por novas estratégias didáticas que atraiam a atenção dos discentes. Pois a aprendizagem dos alunos depende de diversos fatores, tais como: formação acadêmica do professor, as metodologias utilizadas e os recursos disponíveis. É evidente que mesmo sabendo da importância do uso de metodologias alternativas diferenciadas para melhor aprendizagem do aluno, muitos docentes ainda utilizam as aulas expositivas e o livro didático como suas principais metodologias (MORONI et al. 2009).

De acordo com Gardner (1895), a teoria das múltiplas inteligências propõe que cada estudante aprende de forma diferente, e cabe a cada professor descobrir alternativas de ensino e aprendizagem, que contribuam para o desenvolvimento das competências do aluno. Esse fator, associado a dificuldade em ministrar alguns conteúdos de biologia, indica a necessidade de atividades que possibilitem a aprendizagem efetiva para os discentes (MORATORI, 2003).

As atividades pedagógicas ou didáticas, são realizadas com o objetivo de facilitar a aprendizagem diferenciando-se do material pedagógico tradicional, por conter $o$ aspecto lúdico. Para tanto, é importante que o estudante seja envolvido no processo de ensino e aprendizagem de maneira ativa para que ocorra uma aprendizagem significativa. Porém, compreende-se que não há um caminho único que conduza com segurança à aprendizagem, pois são inúmeras as variáveis que se interpõem nesse processo (CUNHA, 1998).

Dessa forma, recorrer a um pluralismo de estratégias e recursos, conduzido por objetivos claros e coerentes, pode garantir maiores oportunidades para a construção do conhecimento, além de fornecer subsídios para que mais alunos encontrem as atividades que melhor ajudem a compreender o tema estudado (KRASILCHIK, 2011). Quando o ensino sai do tradicional e entra no campo da criatividade, o cenário muda e as metodologias alternativas, bem como outras fontes são de grande contribuição para o docente em sala de aula. Para Krasilchik (2004), o uso de jogos didáticos é um exemplo de metodologia simples de simulação, cuja função é ajudar a memorizar fatos e conceitos expostos pelo professor, ajudando assim no processo de ensino e aprendizagem.

Kishimoto, (1996) indicou que a atividade lúdica não é o fim, mas o eixo que conduz a um conteúdo didático específico, resultando em um empréstimo de uma ação eficaz para a aquisição de informações. 0 fato de a atividade ser lúdica, divertida e prazerosa, a torna uma das formas mais eficazes de ensino, sendo uma estratégia para melhorar o desempenho dos alunos em conteúdo de difícil aprendizagem. Portanto, o jogo é uma importante ferramenta educacional, com possibilidade de auxiliar os processos de ensino-aprendizagem em sala de aula, nos diferentes níveis de ensino e nas diversas áreas do conhecimento. Portanto o presente trabalho tem como objetivo aplicar metodologias alternativas para o ensino de genética, uma vez que os professores de ensino superior identificaram que os alunos de ensino médio quando chegam na faculdade apresentam muitas dificuldades para assimilar o conteúdo de genética (MIRANDA, 2001). 


\section{REFERENCIAL TEÓRICO}

\subsection{TEORIAS DA APRENDIZAGEM}

A prática educacional contém abordagens teóricas clássicas para o processo de ensino-aprendizagem. Em todas as teorias, a aprendizagem tem como pressuposto que todo conhecimento é resultado das experiências vividas pelo indivíduo (GIUSTA, 1985).

Nesse sentido, as características individuais são determinadas por fatores externos ao indivíduo. Igualmente, desenvolvimento e aprendizagem ocorrem simultaneamente, considerando, portanto, fatores internos também.

\subsection{COMPORTAMENTALISMO}

Considerando a relação entre o indivíduo e fatores externos gerando o conhecimento, influenciou amplamente teorias psicológicas e pedagógicas que se traduziram em concepções de ensino e aprendizagem empiristas (NEVES \& DAMIANI, 2006).

A concepção de ensino-aprendizagem baseada no empirismo mais imponente é o behaviorismo. Este conceito, ganha sentido a definição de aprendizagem como mudança de comportamento resultante do treino ou da experiência dando origem a teorias de aprendizagem envolvidas principalmente com eventos objetivos, como estímulos, respostas e recompensas (GIUSTA, 1985; LEFRANÇOIS, 2017).

Como consequência da corrente empirista, o processo ensino-aprendizagem se concentra no professor, que organiza as informações do meio externo que deverão ser internalizadas pelos alunos, sendo esses apenas receptores de informações e do seu armazenamento na memória. Todo o conhecimento está fora do sujeito, portanto, no professor e nos livros. 0 aluno é um recipiente vazio onde é necessário "despejar" o conhecimento (NEVES \& DAMIANI, 2006). As teorias behavioristas incluem as de Pavlov, Guthrie, Watson, Skinner, Hull e Thorndike.

\subsection{COGNITIVISMO}

Esta concepção engloba teorias que enfatizam os processos mentais dificilmente observáveis, evidenciando a possibilidade de o aluno adquirir e organizar informações. O conhecimento seria o produto da interação do homem com mundo (HASSARD, 1992). Por isso, o conceito baseado no cognitivismo também é denominado como interacionista ou construtivista. Como influências cognitivistas preponderantes devem ser mencionados Jerome Bruner, Jean Piaget, Lev Vygotsky e Bandura (LEFRANÇOIS, 2017).

Os estudos psicopedagógicos relacionados ao cognitivismo atuais estão interessados na atividade mental humana, e especificamente no processamento de informações, na representação e autoconscientização (GARNHAM, 2009). Segundo Becker (1993), na pedagogia derivada dessa epistemologia interacionista o professor acredita que o aluno só aprenderá alguma coisa, isto é, construirá algum conhecimento novo, se ele agir e problematizar a sua ação e esse processo far-se-á por reflexão. Aprendizagem é, por excelência, construção: ação e tomada de consciência da coordenação das ações. Assim, não se pode exagerar a importância da bagagem hereditária nem a importância do meio social (NEVES \& DAMIANI, 2006). 


\subsection{TEORIAS DA APRENDIZAGEM E O ENSINO DE BIOLOGIA}

As teorias de aprendizagem, tendo surgido, possivelmente, porque conforme salienta Bigge (1977), o homem não só quis aprender como também sua curiosidade o impeliu a tentar aprender como se aprende, são diversas e acompanharam de perto a evolução observada na Psicologia e na Educação em Ciências (VASCONCELOS et al., 2003).

A Aprendizagem por Transmissão pode associar-se às perspectivas behavioristas ou comportamentais da aprendizagem. 0 ensino por transmissão se sustenta nas exposições orais do professor, que transmite as ideias (estímulos) aos alunos, isto é, “...o professor 'dá a lição' e pede, em troca, que os alunos usem a sua atividade mental para acumular, armazenar e reproduzir informações" (SANTOS \& PRAIA, 1992). Nessa lógica instrucional de organizar o ensino, o aluno tem um papel cognitivo passivo, sendo encarado como um mero receptáculo de informações que, mais tarde, serão úteis para a vida (VASCONCELOS et al., 2003).

A teoria behavorista da aprendizagem escolar tem como objetivo principal alcançar comportamentos apropriados por parte dos alunos, basicamente entendidos como apropriação e modificação de respostas. Assim, se a resposta emitida for desejada haverá reforço, cuja natureza dependerá, necessariamente, do nível etário e do esforço dos alunos, por exemplo. Acredita- se que a ineficácia do ensino tradicional foi o fato dos professores não usarem contingências de reforço que acelerassem a aprendizagem (SKINNER apud BIGGE, 1997).

Algumas dificuldades são apontadas a esta teoria. Numa concepção behaviorista de aprendizagem, o aluno é passivo, acrítico e mero reprodutor de informação e tarefas. 0 aluno não desenvolve a sua criatividade e, embora se possam respeitar os ritmos individuais, não se dá suficiente relevo à sua curiosidade e motivação intrínsecas. 0 aluno pode, inclusive, correr o risco de se tornar apático, por ser excessivamente dependente do professor (VASCONCELOS et al., 2003).

Estes fatores acarretam o distanciamento dos alunos ao conhecimento da área de biologia, gerando respostas aversivas ou desagradáveis às aulas. Já que a área biológica é cercada por termos muitas vezes incompreensíveis aos discentes, com regras de nomenclatura, por exemplo.

Embora atualmente sejam as perspectivas cognitivo-construtivista as que mais influenciam as concepções de ensino-aprendizagem nas ciências, ainda surgem algumas formas "mascaradas" dessa pedagogia transmissiva (PRAIA \& MARQUES, 1997). Porém, rejeitando a passividade do aluno face a essa pedagogia de base memorística, de ritmo uniforme e muito assente numa motivação extrínseca do aluno (SANTOS \& PRAIA, 1992), surgem, no ensino das ciências, pressupostos de uma pedagogia ativa que reconhece e valoriza uma maior intervenção do aluno na sua aprendizagem (VASCONCELOS et al., 2003).

Assim, opondo-se a um modelo pedagógico dominantemente marcado, ao nível psicológico, pela corrente behaviorista, surge o modelo da Aprendizagem por Descoberta, Construtivismo ou Cognitivismo. Este modelo propõe, progressivamente, "desinstalar" os referenciais teóricos de uma pedagogia transmissiva dominante nas práticas dos professores. De acordo com essa teoria, defende-se uma aprendizagem ativa, requerendo explorações e descobertas efetivas para o alcance de uma verdadeira compreensão (VASCONCELOS et al., 2003). 
Entre os representantes do cognitivismo, os teóricos mais relevantes para o ensino de ciências que devem ser mencionados o psicólogo norte-americano Jerome Bruner (1963) e o biólogo que formou escola na Suíça, Jean Piaget, devido ao interesse de ambos para que os alunos lidassem com objetos e realizassem experiências para obterem melhorias na aprendizagem (KRASILCHIK, 2011).

A abordagem da aprendizagem de Bruner impulsionou reformas no ensino das ciências. Contudo, embora implicando o aluno no processo de aprendizagem, a aprendizagem por descoberta pode exagerar ao pretender assumir a convicção de que o aluno aprende por conta própria qualquer conteúdo científico. Se por um lado, o papel central da aprendizagem é, agora, do aluno e não do professor, por outro lado, dá-se relevo à análise da estrutura do assunto científico a aprender e pouco significado é atribuída ao contexto da aprendizagem. Essa perspectiva de ensino é especialmente apropriada para a aprendizagem do método científico (como o novo conhecimento é descoberto). Assume-se que ao exercitar as capacidades processuais e procedimentais, relativamente ao método científico, o aluno desenvolve o pensamento e a aprendizagem (CACHAPUZ et al., 2000; VASCONCELOS et al., 2003).

Neste contexto, Bruner foi um dos teóricos que valorizaram o desenvolvimento de habilidades intelectuais, colocando o estudante face às chamadas "situações discrepantes", que provocariam a necessidade de solução. Sua teoria enfatiza o papel da curiosidade e a possibilidade de aceitar várias formas de resolver as questões propostas. Ao analisar essas soluções, o professor deve dar informações aos estudantes sobre sua apreciação das mesmas como fonte de motivação (KRASILCHIK, 2011).

Jean Piaget considera o aprendizado um processo ativo em que estruturas cognitivas resultam da interação dinâmica entre o organismo e o ambiente por processos denominados assimilação, equilibração e autorregulação. Admite ainda que os fatores que influenciam no desenvolvimento de estruturas mentais e na maturação do ser humano são as relações com o ambiente e com o meio social (KRASILCHIK, 2011).

Contudo, o processo do ensino, em geral, e de ciências e biologia, em particular, devem ser adaptados à maneira como o raciocínio se desenvolve, enfatizando o aprendizado ativo por meio do envolvimento dos estudantes em atividades de descoberta. 0 professor não é apenas um transmissor de informações, mas um orientador de experiências, em quem os alunos buscam conhecimento pela ação e não somente pela linguagem escrita ou falada. Estas, embora expressem pensamentos, não substituem a experiência ativa e pessoal (KRASILCHIK, 2011).

\subsection{ENSINO DE GENÉTICA}

Atualmente, assuntos relacionados a genética são comumente citados pela mídia, em âmbitos familiares e escolares. No entanto, estes tópicos tiveram pouca penetração nos programas de ensino e um dos principais motivos para tal evidencia, é o fato dos professores não possuírem formação teórico-prática atualizada (LORETO E SEPEL, 2006).

No Brasil, apesar das inovações científicas e tecnológicas fazerem parte dos currículos escolares, especialmente das escolas públicas, grande parte dos discentes não contextualiza o ensino de biologia, com destaque aos conteúdos de genética, que se tem na escola com a sua realidade (MOURA et al., 2013).

Segundo Oca (2005), os conteúdos de genética na educação básica pública, muitas 
vezes, são considerados difíceis e desinteressantes, não permitindo ao aluno fazer a correlação de que tópicos como ciclo celular, constituição e funcionamento da molécula de DNA, entre outros, abordados em sala de aula são a base para a criação de tecnologias que darão origem, por exemplo, aos transgênicos ou terapias gênicas utilizadas em prol da sociedade.

Para instigar o interesse e a atenção dos discentes pelos assuntos relacionados a genética, faz-se necessário o desenvolvimento de habilidades e competências para a compreensão, sistematização e reelaboração de fatos (KRASILCHIK, 2000; SILVA E CICILLINI, 2008). Para a realização desta tarefa é necessário que o educador planeje procedimentos didáticos que instiguem o aluno a refletir e aplicar os conteúdos dados em sala de aula na resolução de situações problemas cotidianos (CARABETTA, 2010).

Para corroborar com as afirmações acima, Temp et al. (2011) complementa dizendo que:

\begin{abstract}
"Há formas diferenciais de se oportunizar uma educação diferencial sem precisar usar laboratórios, bastando um pouco de criatividade e a responsabilidade do professor em saber que seu papel é o de inserir os estudantes no mundo científico onde vivem para que possam, pelo menos, tomar decisões e dialogar sobre diferentes temas usando o conhecimento científico ao invés de um conhecimento popular aprendido, muitas vezes, nos telejornais"
\end{abstract}

Para tanto, é importante que o estudante seja envolvido no processo de ensinoaprendizagem de maneira ativa para que ocorra uma aprendizagem significativa. Porém, compreende-se que não há um caminho único que conduza com segurança à aprendizagem, pois são inúmeras as variáveis que se interpõem nesse processo. Dessa forma, recorrer a um pluralismo de estratégias e recursos, conduzido por objetivos claros e coerentes, pode garantir maiores oportunidades para a construção do conhecimento, além de fornecer subsídios para que mais alunos encontrem as atividades que melhor ajudem a compreender o tema estudado (KRASILCHIK, 2011). Quando o ensino sai do tradicional e entra no campo da criatividade, o cenário muda e as metodologias alternativas, bem como outras fontes são de grande contribuição para o professor em sala de aula.

E 2002, os Parâmetros Curriculares Nacionais para o Ensino Médio já almejava que a área de ciências da natureza propiciasse um aprendizado útil a vida e ao trabalho, e desenvolvesse no aluno da escola pública competências, habilidades e valores que lhes permitissem uma crítica sobre a natureza das ciências e do conhecimento científico (MOURA et al., 2013).

Metodologias alternativas voltadas para o ensino-aprendizagem são meios que possibilitam o desenvolvimento cognitivo e o senso crítico dos alunos. Segundo Conde et al. (2013), no processo de reconstrução da aprendizagem, os alunos percebem quão importantes é tornar a educação dinâmica e demonstram-se profundamente comprometidos com a qualidade do ensino. 


\section{MATERIAL E MÉTODOS}

\subsection{LOCAL DE COLETA}

A pesquisa foi realizada na Escola Estadual Engenheiro Arthur Soares Amorim, localizada no núcleo 15 do Bairro Cidade Nova. Houve a participação de 69 discentes (33 alunos da turma "A" e 36 alunos da turma "B") que foram analisados através da aplicação das três metodologias propostas (áudio visual, lúdica e tradicional) aplicadas aos alunos para avaliar o desenvolvimento cognitivo.

O conteúdo sobre genética molecular a ser abordado em sala de aula foi subdividida em dois tópicos com utilização de duas metodologias distintas: (1) Exposição Audiovisual com atividade lúdica; (2) Aula tradicional, usando o livro "Ser Protagonista" adotado pela escola. E para definir a metodologia mais adequada, foi realizada uma avaliação diagnóstica (tradicional) para definir a melhor fixação dos tópicos expostos de acordo com as metodologias aplicadas.

\subsection{PRIMEIRO MÉTODO UTILIZADO}

Exposição do conteúdo: "Introdução à genética molecular" e a "estrutura dos ácidos nucléicos" com auxílio de recurso áudio visual (Datashow) com projeções de slides e vídeos relacionados ao assunto abordado.

Posteriormente foi realizada uma atividade lúdica denominada "jogo em busca do material genético" criada pelo corpo docente do projeto. Onde o conteúdo foi abordado no decorrer da atividade.

\subsection{SEGUNDO MÉTODO UTILIZADO}

Os alunos realizaram atividades tradicionais tendo como material de apoio o livro didático "Ser Protagonista". Os alunos fizeram leitura do conteúdo proposto "estrutura dos ácidos nucléicos" e o professor explicou o conteúdo com auxílio do quadro branco e pincel.

\subsection{AVALIAÇÃO}

A avaliação consistiu em uma avaliação escrita contendo seis questões sendo três de múltipla escolha e três questões dissertativas.

\section{RESULTADOS E DISCUSSÕES}

$\mathrm{Na}$ turma "A" as aulas foram expostas com auxílio de projetor (Datashow) e computador (notebook). Foram projetados vídeos e slides, onde os alunos puderam visualizar a estrutura do material genético para melhor compreensão do assunto ministrado. Em seguida foi realizada uma atividade lúdica "jogo em busca do material genético" criado pelo projeto.

Na turma "B" foi aplicada uma metodologia que os alunos estão habituados, com o auxílio do livro didático "Ser Protagonista", houve leituras com participação dos discentes e exposição do conteúdo com auxílio do quadro branco.

Após a exposição do conteúdo, em ambas as turmas foi realizada o mesmo 
recurso avaliativo para aferir o nível de aprendizagem obtido com as diferentes metodologias.

Na turma "A", dos 33 alunos avaliados, oito apresentaram coeficiente abaixo da média exigida pela escola. Enquanto que 25 alunos alcançaram coeficiente acima da média exigida. Na turma "B", dos 36 alunos avaliados, 16 obtiveram coeficiente abaixo da média e 20 alunos apresentaram coeficiente acima da média (Tabela 1).

Tabela 1: Resultado da avaliação das metodologias aplicadas

\begin{tabular}{|c|c|c|c|c|c|c|}
\hline \multirow{2}{*}{ Turma } & \multirow{2}{*}{$\begin{array}{l}\text { Total de } \\
\text { alunos }\end{array}$} & \multirow{2}{*}{ Método } & \multicolumn{4}{|c|}{$\begin{array}{l}\text { Valor do questionário ( } 0 \text { a } 10) \text { e média (\%) dos } \\
\text { testes aplicados }\end{array}$} \\
\hline & & & $<6$ & $\%$ & $>6$ & $\%$ \\
\hline A & 33 & $\begin{array}{l}\text { Áudio visual } \\
\text { Lúdico }\end{array}$ & 8 & $24,24 \%$ & 25 & $75,76 \%$ \\
\hline $\mathrm{B}$ & 36 & Tradicional & 16 & $44,44 \%$ & 20 & $55,56 \%$ \\
\hline
\end{tabular}

Os dados apresentados na tabela representam o índice de aprovação dos alunos da turma "A" e turma "B" que participaram da pesquisa. Verificou-se que os alunos da turma "A" apresentaram melhores resultados de acordo com suas respectivas notas $(>6)$ predominando 25 alunos (75,76\%) de aprovação.

Métodos são criados e aplicados para que docentes e discentes possam ter uma melhor interatividade e motivação durante as aulas ministradas em sala de aula. De acordo com Moraes e Varela (2007), a motivação para os alunos é essencial para que o ensino/aprendizagem seja de fato um fator que influencia na formação do aluno e no meio em que está inserido.

No processo de avaliação que dinamiza e regula a aprendizagem dos discentes deve ser parte de fluxo continuo. 0 arranjo curricular de uma instituição de ensino deve ser organizado de forma flexível para que se possa diversificar o atendimento as necessidades de seus alunos, com a finalidade de construir uma nova metodologia de ensino, quebrando as barreiras do método tradicional e alinhando-se às novas metodologias alternativas (MORAES E VARELA, 2007).

Metodologias alternativas voltadas para o ensino/aprendizagem são meios que possibilitam o desenvolvimento cognitivo dos alunos. Segundo Conde, Lima e Bay (2013), no processo de reconstrução da aprendizagem, os alunos percebem quão importantes é tornar a educação dinâmica, e, demonstram-se profundamente comprometidos com a qualidade do ensino.

De acordo com resultados encontrados no estudo, percebemos que metodologias alternativas que fogem do tradicionalismo do ensino, são evidenciadas por outros autores como uma maneira de ensino mais eficaz. Nesta pesquisa, as potencialidades foram mais relevantes do que as fragilidades dos alunos. Isso foi demonstrado na tabela 1 através dos resultados obtidos. 


\section{CONCLUSÃO}

A presente pesquisa demonstrou que metodologias alternativas podem ser mais eficazes do que a metodologia tradicional. Certamente não podemos descartar alguns métodos de ensino que percorre durante muito tempo, no entanto, novas tecnologias que surgiram ao longo de décadas vieram para subsidiar os profissionais da docência na busca de novas alternativas procurando uma melhor compreensão dos temas abordados em sala de aula. Dentro do tema proposto nessa pesquisa, a biologia molecular apresenta conceitos de entendimento complexo, entretanto, o método utilizado com os alunos fez com que o entendimento sobre a disciplina se tornasse mais claro, levando-os a um percentil de aprovação superior ao método tradicional. Deste ponto de vista, concluímos que a metodologia alternativa pode ser usada nas escolas com alunos de várias faixa etárias e de diferentes disciplinas.

\section{REFERÊNCIAS}

BECKER, F. Modelos Pedagógicos e Modelos Epistemológicos. Porto Alegre. Paixão de Aprender, n.5:18-23, 1993.

BIGGE, M. L. Teorias da aprendizagem para professores. São Paulo: Editora Pedagógica e Universitária, 1977.

BZUNECK, J. A. As crenças de auto-eficácia dos professores. In: F.F. Sisto, G. de Oliveira, \& L. D. T. Fini (Orgs.). Leituras de psicologia para formação de professores. Petrópolis, Rio de Janeiro: Vozes, 2000.

CACHAPUZ, A. F., PRAIA, J. F., \& JORGE, M. P. Perspectivas de Ensino das Ciências. Em A. Cachapuz (Org.), Formação de Professores/Ciências. Porto: CEEC. 2000.

CARABETTA, V. J. Uma investigação microgenética sobre a internalização de conceitos de biologia por alunos do ensino médio. Revista Contemporânea de Educação, Rio de Janeiro, v. 5, n. 10, p. 1-10, 2010.

CONDE, T. T.; LIMA, M. M. E BAY, M. Utilização de metodologias alternativas na formação dos professores de biologia no IFRO - Campus Ariquemes. Revista Labirinto, Ano XIII. no 18.2013.

CUNHA, N. Brinquedo, desafio e descoberta. Rio de Janeiro: FAE.1998.

GARDNER, H. Frames of mind. New york, Basic Books Inc. 1985.

GARNHAM, A. Cognitivism. In J. Symons \& P. Calvo. The routledge companion to philosophy of psychology. Nova York: Routledge/ Taylor \& Francis, 2009.

GIUSTA, A. S. Concepções de Aprendizagem e Práticas Pedagógicas. Educ. Rev.,v.1: 24-31. 1985.

HASSARD, J. Minds on Science. USA, Harper Collins, 1992.

KISHIMOTO, T. M. Jogo, brinquedo, brincadeira e a educação. Cortez, São Paulo, 1996. 
KRASILCHIK, M. Prática de Ensino de Biologia. 4⿳亠丷厂 Ed., Editora da Universidade de São Paulo, 2011. 200p.

$197 p, 2004$.

Prática de Ensino de Biologia. $4^{\mathrm{a}}$ ed., Editora da Universidade de São Paulo,

Reforma e realidade: o caso do ensino de ciências. São Paulo em Perspectiva. São Paulo, v. 14, n. 1, p. 85-93, 2000.

LEFRANÇOIS, G. R. Teorias da Aprendizagem: o que o professor disse. São Paulo: Cengage Learning, 2017.

LORETO, E. L. S.; SPEL, L. M. N. Formação Continuada de Professores de Biologia do Ensino Médio: Atualização em Genética e Biologia Molecular. Programa de Incentivo à Formação Continuada de Professores do Ensino Médio. Santa Maria, 2006.

MIRANDA, S. No fascínio do jogo, a alegria de aprender. Ciência Hoje, v. 28, n. 168, p.6466. 2001.

MORAES, C. R.; VARELA, A. Motivação do Aluno Durante o Processo de EnsinoAprendizagem. Revista Eletrônica de Educação. Ano I. No. 01. 2007.

MORATORI, P.B. Por que utilizar jogos educativos no processo de ensino aprendizagem? Rio de Janeiro UFRJ, 2003.

MORONI, F.T.; MORONI, R.B.; JUSTINIANO, S.C.B.; SANTOS, J.M.M. Pescando nucleotídeos: um novo jogo educativo para o ensino do processo de síntese proteica para estudantes do ensino médio. Revista de Ensino de Bioquímica, v. 7, n. 1, p. 36-40, 2009.

MOURA, J.; DEUS, M. S. M.; GONÇALVES, N. M. N.; PERON, A. P. Biologia/Genética: 0 ensino de biologia, com enfoque a genética, das escolas públicas no Brasil - breve relato e reflexão. Semina: Ciências Biológicas e da Saúde, Londrina: 2013.

NEVES, R. A.; DAMIANI, M. F. Vygotsky e as teorias da aprendizagem. UNIrevista, v. 01, n. 2. 2006.

OCA, I. C. M. Que aportes oferece La investigación reciente sobre aprendizagem para fundamentar nuevas estrategias didácticas? Revista Educación, México, v. 19, n. 1, p. 7 16, 2005.

PRAIA, J. F., MARQUES, L. Das práticas dos professores de Ciências (Geologia/Biologia) à mudança em torno das suas concepções de ensino. Em A. Estrela, R. Fernandes, F. A. Costa, I. Narciso \& O. Valério (Orgs.),Contributos da Investigação Científica para a qualidade do ensino (pp. 145-154). 1997.

SANTOS, M. E., PRAIA, J. F. Percurso de mudança na Didáctica das Ciências: Sua fundamentação epistemológica. Em F. Cachapuz (Org.), Ensino das Ciências e Formação de Professores: Projecto MUTARE 1 (pp. 7- 34). Aveiro: Universidade de Aveiro. 1992.

SILVA, M. O.; CICILLINI, G. A. O potencial das discussões polêmicas nas aulas de Biologia. Universidade, necessárias utopias e distopias; semana do servidor; semana acadêmica. 
Uberlândia: Universidade Federal de Uberlândia, 2008. p. 1-7.

TEMP, D.S.; CARPILOVSKY, C.K.; GUERRA, L. Cromossomos, gene e DNA: utilização de modelo didático. São Paulo. Anais, Congresso Brasileiro de Genética. 2011.

VASCONCELOS, C.; PRAIA, J. F.; ALMEIDA, L. S. Teorias de aprendizagem e o ensino/aprendizagem das ciências: da instrução à aprendizagem. Psicol. esc. educ., Campinas, v. 7, n. 1, p. 11-19, jun. 2003. 


\section{Capítulo 3}

\section{Educação em saúde para o controle de Aedes aegypti}

\section{Paula Figliuolo da Cruz, Borges}

\section{Thaís Nunes dos Santos}

\section{Renata Figliuolo da Cruz Tupinambá}

Resumo: Aedes aegypti é o principal vetor de diferentes arbovírus ao homem, sendo a dengue com maior índice de morbidade e mortalidade no Brasil e no mundo. Considerando a inexistência de tratamentos específicos e vacinas disponíveis, exceto para a dengue, o controle desses vírus acontece mais comumente pelo combate ao mosquito vetor. Para tanto, a educação em saúde é a maneira mais eficiente de modificar o comportamento humano em relação à disponibilização de depósitos que se tornam criadouros favoráveis ao desenvolvimento de Ae. aegypti. Diante disso, foi realizado uma revisão bibliográfica com base em artigos científicos publicados no Brasil, acerca dos diferentes métodos aplicados para o ensino da temática da dengue e a promoção da saúde.

Palavras-chave: vigilância entomológica; mosquito vetor; práticas pedagógicas; 10 minutos contra a dengue. 


\section{INTRODUÇÃO}

A educação em saúde no contexto do controle das arboviroses é a maneira mais eficiente e adequada para a mudança do comportamento humano, frente à grande disponibilidade de criadouros do Aedes aegypti (CHIARAVALLOTI-NETO, 1997; TAUIL, 2001).

Ae. aegypti é um importante inseto vetor de diferentes arbovírus (DENV, CHIKV, ZIKV, FAU), os quais causam elevadas taxas de notificações no Brasil (BRASIL-MS, 2019) e no mundo (BHATT et al., 2013). Para o controle desse mosquito, o PNCD (Programa Nacional de Controle da Dengue) preconiza o controle integrado, envolvendo diferentes metodologias, sendo o controle mecânico considerado a melhor opção em longo prazo. Para tanto, o controle dos criadouros requer a participação da população (BRAGA e VALLE, 2007), uma vez que o mosquito é um inseto doméstico e altamente adaptado ao convívio humano.

A responsabilização social e sensibilização sobre o ciclo de vida dos vetores se faz importante para que cada cidadão se sinta responsável pela qualidade do meio ambiente em que vive, adaptando ao seu cotidiano o uso de medidas que minimizem a propagação do mosquito. Diante disso, este estudo apresenta uma revisão de literatura acerca da bibliografia disponível sobre as ferramentas pedagógicas aplicadas para a educação em saúde no Brasil, na perspectiva do controle de Ae. aegypti.

\section{REFERENCIAL TEÓRICO}

\subsection{CONSIDERAÇÕES SOBRE O AEDES AEGYPTI}

Ae. aegypti (Figura 1A), é um mosquito pertencente à Ordem Diptera e Família Culicidae, considerado uma das espécies mais adaptadas e dependentes do ambiente urbano, principalmente por ser altamente antropofílico (CONSOLI E LOURENÇO-DEOLIVEIRA, 1994; FORATTINI, 2002). Considerado um importante inseto invasor, Ae. aegypti teve sua distribuição pelos continentes tropicais e subtropicais do planeta influenciado pelas atividades humanas (POWELL; TABACHNICK, 2013).

Os culicídeos têm desenvolvimento holometábolo, ou seja, apresentam metamorfose completa com o ciclo de vida iniciada no ovo, passando por quatro fases larvais, pupa e adulto. As fêmeas de Aedes sp. depositam seus ovos em superfícies úmidas dos reservatórios e criadouros, com preferência por substratos escuros, rugosos e com águas não poluídas (FORATTINI, 2002). Os ovos de Aedes sp. são resistentes à dessecação e ficam aderidos ao substrato até a eclosão. Quando secos, os ovos podem permanecer viáveis por muitos meses, em estado de quiescência embrionária, eclodindo após serem inundados novamente (CONSOLI E LOURENÇO-DE-OLIVEIRA, 1994; FORATTINI, 2002). Essas condições biológicas favorecem a disseminação das espécies de mosquitos Aedes através da dispersão passiva, além de contribuir com a complexidade do controle efetivo do mosquito.

Ae. aegypti é o principal vetor dos quatro sorotipos do dengue (DENV-1 - DENV4), do chikungunya (CHIKV), do Zika (ZIKV) e da febre amarela urbana (FAU), no continente americano (KRAEMER et al., 2015; SOUZA-NETO et al., 2019). Entre as endemias tropicais, a dengue tem destaque por ser a arbovirose com maior prevalência e impacto epidemiológico no mundo. Mesmo com um grande número de casos subnotificados, a estimativa é de que 390 milhões de pessoas sejam infectadas pelo dengue, por ano (BHATT et al., 2013). 


\subsection{VIGILÂNCIA E CONTROLE VETORIAL}

A vigilância entomológica constitui um fator indispensável para o controle das doenças causadas pelos patógenos transmitidos por mosquitos vetores. As ações de controle ao Ae. aegypti no Brasil remontam ao início do século $\mathrm{XX}$, devido às grandes epidemias de febre amarela urbana que aconteciam naquele momento. Entre as décadas de 1930 e 1940, várias campanhas de erradicação de Ae. aegypti nas Américas foram realizadas. Ae aegypti foi considerado erradicado no Brasil por duas vezes, em 1955 e 1973. Contudo, com a descontinuidade das ações de vigilância e controle entomológico, foi confirmada a reintrodução do mosquito no país (BRAGA; VALLE, 2007).

Desde então, grandes campanhas de saúde pública buscam minimizar as enfermidades relacionadas a esse vetor. Após várias tentativas sem grandes sucessos no controle da infestação de Ae. aegypti e nos casos de dengue, o Ministério da Saúde (MS) implementou em 2002, o Programa Nacional de Controle da Dengue (PNCD), ainda vigente. 0 objetivo principal do PNCD foi centralizado em três componentes fundamentais: 1) redução da infestação de Ae. aegypti; 2) redução da incidência da dengue e 3) redução da letalidade por dengue hemorrágica (BRASIL-MS, 2002).

O PNCD manteve o foco nos municípios prioritários $(\geq 50$ mil habitantes e considerados receptivos à introdução de novos sorotipos de dengue), visando a melhoria de alguns aspectos na estrutura do controle vetorial brasileiro, como e.g.: a elaboração de campanhas de divulgação de conteúdo e mobilização da população; o fortalecimento da vigilância epidemiológica e entomológica para melhorar a detecção precoce de surtos da doença; e, integração de ações de controle da dengue na atenção básica (BRASIL-MS, 2002).

Para monitorar a densidade de Ae. aegypti, o PNCD recomenda a visita domiciliar "casa a casa" para a pesquisa larvária, que consiste na inspeção de depósitos, os quais são potenciais criadouros de reprodução do vetor. Os depósitos positivos para formas imaturas de Ae. aegypti recebem o tratamento indicado conforme sua classificação, podendo ser por controle físico, biológico ou químico (BRASIL-MS, 2002; 2009).

O controle físico, também chamado de controle mecânico, é baseado em intervenções diretas de acordo com a classificação dos depósitos positivos ou que podem ainda tornar-se positivos para larvas de Aedes. 0 controle biológico baseia-se na utilização de predadores naturais ou patógenos diretamente nas formas imaturas do mosquito. $\mathrm{O}$ controle químico acontece por meio de inseticidas, de origem orgânica e inorgânica, os quais podem ser utilizados tanto nas formas imaturas quanto nos mosquitos adultos ( BRAGA; VALLE, 2007; BRASIL-MS, 2009; ZARA et al., 2016).

\subsection{EDUCAÇÃO PARA O VETORIAL}

O PNCD preconiza o controle integrado, uma estratégia combinada de metodologias, com o intuito de melhorar a eficácia, o custo-benefício e a integridade ecológica no processo de controle dos vetores. A abordagem deve ser utilizada de forma racional e prática visando, principalmente, a utilização de medidas de educação sanitária e manejo ambiental, incluindo a mobilização dos moradores (BRASIL-MS, 2009; DONALÍSIO; GLASSER, 2002).

Sabe-se que o comprometimento e participação da comunidade na implementação de intervenções de controle vetorial são fundamentais, uma vez que a população é coautora e responsável pela manutenção das baixas densidades do vetor. 
A educação é a maneira mais eficiente de modificar o comportamento humano em relação à disponibilização de habitats larvares favoráveis ao Ae. aegypti (CHIARAVALLOTI-NETO, 1997; CLARO; TOMASSINI; ROSA, 2004). O enfoque da responsabilidade social e sensibilização sobre a problemática do tema dos vetores, é baseada na perspectiva de que cada cidadão é responsável pela qualidade do meio ambiente em que vive, adaptando ao seu cotidiano o uso de medidas que impeçam ou minimizem a propagação do vetor.

\section{MATERIAL E MÉTODOS}

Este estudo trata-se de uma revisão de literatura, na qual foi realizado um levantamento de bibliografias baseado em artigos científicos publicados entre os anos de 2010 e 2021. Os artigos foram buscados nas bases de dados contidas no National Center for Biotechnology Information (NCBI) - PubMed, Scientific Eletronic Library Online (SCIELO) e Google Scholar.

Os descritores (português e inglês) usados para as pesquisas foram: "educação e controle de Aedes aegypti", "educação em saúde no Brasil", "controle integrado", "vigilância e educação em saúde", "educação e controle da dengue", "participação social e controle da dengue".

Inicialmente, foram pré-selecionados 36 artigos baseados na relevância do título. 0 critério de inclusão para triagem dos artigos foi embasado na compatibilidade dos métodos com o tema deste estudo. Para análise e discussão, foram selecionados 19 artigos, os quais todos foram escolhidos fundamentados no emprego de ferramentas pedagógicas aplicadas em populações brasileiras, sem distinção de região, grupos populacionais e/ou faixas etárias.

\section{RESULTADOS E DISCUSSÃO}

Educação em saúde (ES) é processo persistente, continuado, crítico e reflexivo, que visa a construção de conhecimentos nas mais variadas diretrizes da saúde. Temas em saúde contribuem com o desenvolvimento da autonomia das pessoas em suas práticas de autocuidado e de sua coletividade (GOHN, 2004; MEDEIROS, 2018). A ES apresenta-se como uma estratégia para que o exercício da cidadania seja pauta das ações educativas, perpassando por vários setores da sociedade (CÂMARA et al., 2012).

No contexto das arboviroses, é imprescindível que ES baseie-se em abordagens que transcendem a tradicional temática da "areia no vasinho". Valle (2016) aborda o quão é fundamental o envolvimento de todo contexto dos determinantes biológicos num enfoque higienista, trazendo o cidadão como coautor do processo vigilância e controle de Aedes aegypti.

As intervenções de rotina preconizadas pelo PNCD são fundamentais para favorecer o envolvimento da comunidade nas atividades de procura e remoção de criadouros (TAUIL, 2001).

Nessa perspectiva, Caprara et al. (2015) mostraram a eficácia do programa ecosaúde, em Fortaleza (CE), com impacto significativo nas densidades de Ae. aegypti por meio de intervenções direcionadas nos tipos de recipientes mais produtivos. 0 estudo foi baseado em um manejo ambiental e engajamento social, os quais tiveram sucesso com o empoderamento das comunidades, preestabelecendo autonomia quantos aos 
cuidados com possíveis focos do vetor, favorecendo a disposição e participação de ações preventivas e o aumento de conhecimento da população acerca da dengue.

A ES deve ser voltado a qualquer faixa etária, uma vez que os diferentes temas transversais de saúde e meio ambiente abordados têm por finalidade a promoção da saúde. No entanto, o meio escolar é considerado um ambiente ideal para a introdução de temas de ES, pois é uma fase com capacidade mais favorável ao desenvolvimento de competências e habilidades que podem modificar o futuro de uma população em prol da saúde pública (CÂMARA et al., 2012; SANTOS-GOUW; BIZZO, 2009).

As práticas educacionais em saúde são uma ferramenta que auxiliam e complementam o processo de ensino, principalmente com a incorporação do lúdico (MACHADO, 2019). São uma excelente maneira de promover aprendizagem significativa, mudanças nos hábitos dos estudantes e de seus familiares, os quais se tornam disseminadores do conhecimento (SILVA et al., 2017).

A confecção de armadilhas em garrafa pet para o mosquito da dengue mostrou-se uma prática pedagógica muito favorável ao entendimento sobre o ciclo de vida do mosquito, entre crianças com idade entre 11 e 14 anos, da cidade de Chapadão do Sul, Mato Grosso do Sul (Figura 1A). A montagem desse modelo didático foi importante para que os alunos compreendam que a maneira mais adequada da prevenção da dengue é com a eliminação dos vetores e de seus criadouros (SILVA et al., 2017). A estratégia de produzir armadilhas em garrafa pet também foi aplicada em alunos do Ensino Fundamental de Campinas, São Paulo (ROBERTO, 2016) e do Paraná (ESTEVEZ, 2016).

Práticas educativas para fortalecer o aprendizado de estudantes, com a aplicação de questionários, distribuição de panfletos, cartilhas educativas e aplicação de palestras e circuitos sobre o ciclo de vida do mosquito, são comumente aplicadas nas escolas brasileiras (FONSECA; LISBOA; MARTEIS; MAKWSKI; SANTOS, 2011; MARISCO, 2020; PAULA et al., 2020; SILVA; DAROSCI; ALMEIDA, 2012; VIEIRA; SANTOS; OLIVEIRA, 2015).

Modificar a realidade do ensino, com a aplicação de uma linguagem prática e direta é uma ferramenta fundamental e mediadora do processo de aprendizagem. Roberto (2016) realizou uma sequência didática de práticas educativas com alunos de Ensino Fundamental de uma escola de Campinas (SP) e percebeu a importância da interação das crianças na comunicação, na troca de ideias, na cooperação uns com os outros. Estes aspectos são relevantes e ajudaram na aprendizagem dos conceitos científicos das crianças participantes do estudo, as quais tiveram a experiência de compreender a vida do Ae aegypti em diferentes perspectivas. Além da produção de armadilhas e panfletos, os alunos elaboraram painéis, ilustrações, cruzadinhas e fizeram busca ativa das formas imaturas do vetor no interior da escola e em suas casas (Figura 1B).

Estudo com diferentes práticas educativas também foi realizado por Cantarelli e Ferraz (2012), em uma escola do Ensino Fundamental do município de Cascavel, Paraná em que tiveram como proposta atingir os diversos estilos de aprendizagem com estratégias variadas. Os autores evidenciaram a seriedade e o compromisso social que nortearam as atividades executadas pelas crianças, as quais apresentaram avanços na apreensão dos conhecimentos e maturidade quanto as informações acerca da situação da dengue no município e no bairro residente. 
0 trabalho educativo com professores também é fundamental. Brassolatti Andrade (2002) realizaram cursos de treinamento sobre a temática dengue, com a proposta de treinar, instrumentalizar e estimular esses profissionais, uma vez que são educadores e multiplicadores junto aos colegas de profissão, com outros profissionais da escola, aos alunos e, por extensão, à comunidade como um todo. A proposta do estudo possibilitou a redução dos focos do mosquito, com a eliminação dos criadouros observados.

A educação ambiental, uma vertente da ES, foi proposto por Cruz-Borges (2018), a qual realizou diversas atividades de manejo ambiental, junto a oficinas com a mostra de mosquitos adultos e imaturos de Aedes sp. e aplicação dos "10 minutos contra a dengue", para moradores e turistas da Ilha de Paquetá, Rio de Janeiro (Figura 1C). Educação ambiental também foi aplicada por Caregnato et al. (2008), em Porto Alegre, Rio Grande do Sul. Esta proposta estabelece uma relação positiva entre ganho de conhecimento e mudança de hábito entre os participantes das ações educativas.

Os "10 minutos contra a dengue" é uma proposta do Instituto Oswaldo Cruz (IOC/Fiocruz), cuja estratégia é interromper o ciclo de vida do Ae. aegypti, utilizando apenas 10 minutos semanais para limpeza dos principais criadouros do mosquito (IOC, 2011). Considerando que o ciclo de vida do Ae. aegypti é curto, de 7 a 10 dias, esse momento dedicado à vigilância dos depósitos é determinante na manutenção reduzida, ou quiçá quase nula, das populações do mosquito.

Figura 1. Práticas pedagógicas para a promoção do conhecimento sobre o Aedes aegypti. (A) Armadilha para o Aedes sp.; (B) Cruzadinha e ilustração; (C) demonstração sobre o ciclo de vida do Aedes sp.
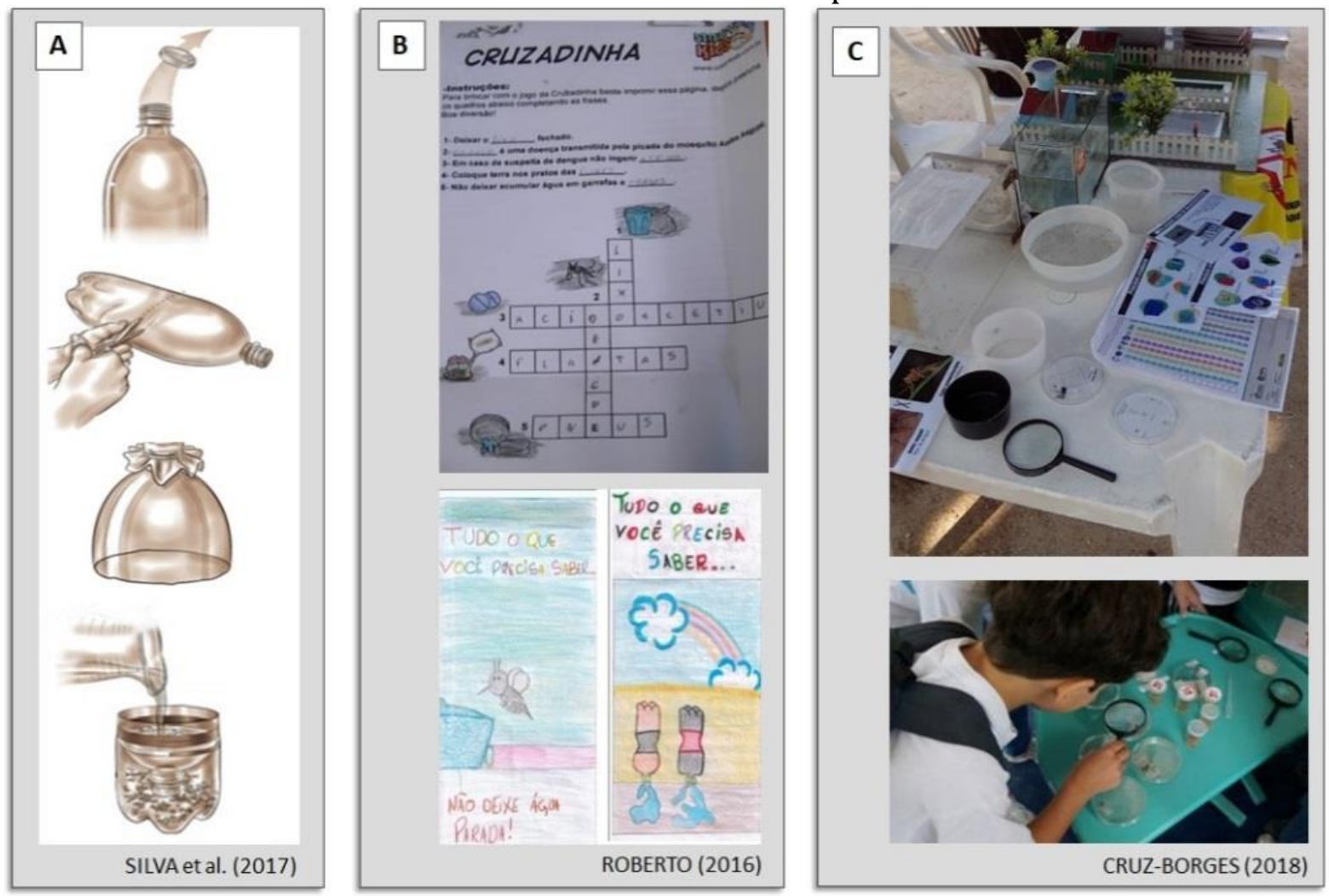
Ações de mobilização social são fundamentais para a propagação do conhecimento e mudanças no comportamento e hábitos da população, principalmente quando o enfoque é o combate aos criadouros potenciais de larvas de Aedes, intimamente relacionados ao homem, como por exemplo o descarte de resíduos humanos e reservatórios de água (LIMA; VILASBÔAS, 2011; TAUIL, 2001).

Um dos grandes problemas que envolvem o controle dos arbovírus transmitidos pelo Ae. aegypti, é que as ações educativas de combate ao vetor ocorrem, em maior densidade, de forma sazonal, as quais se concentram em temporadas próximas ao verão ou em dias programados, como a prática de campanha do "Dia D da Dengue" (SILVA et al., 2011), a qual objetiva atender aos prováveis surtos epidemiológicos.

A dengue tem padrão sazonal no Brasil, seguindo as elevadas incidências durante o período chuvoso (CODEÇO et al., 2015). Todavia, a dengue é uma endemia no Brasil, com elevados casos notificados durante todo ano, além das outras arboviroses que ocorrem em concomitância (BRASIL-MS, 2019). Portanto, o caráter sazonal das campanhas educativas contra o Ae aegypti deve ser substituído por uma educação permanente, que colabore com o conhecimento popular e que promova intervenções considerando a realidade social e cultural das pessoas (RANGEL, 2008; SILVA; MALMANN; VASCONCELOS, 2015).

Nesse contexto, diante da revisão de literatura, pode-se perceber que o controle de endemias é uma missão que requer o Estado e o cidadão como protagonistas. A utilização de estratégias educativas baseadas na educação em saúde, junto aos diferentes atores sociais envolvidos no processo, é fundamental para a implementação de ações de vigilância e controle do Ae. aegypti.

\section{CONCLUSÃO}

A educação em saúde direcionada ao controle do Ae. aegypti deve ser um processo contínuo, considerando que o ciclo desse mosquito acontece em um curto período e seus ovos resistem a dessecação. Educar as crianças e os jovens para as práticas de manejo ambiental, de forma lúdica, é uma ferramenta que pode tornar-se sustentável e eficiente em seu meio familiar. Do mesmo modo, a educação é promissora para todas as faixas etárias, pois colabora com a redução das populações do mosquito e, consequentemente, com a redução da circulação dos arbovírus. 


\section{REFERÊNCIAS}

BHATT, S. et al. The global distribution and burden of dengue. Nature, 496 (7446): 504507, 2013.

BRAGA, I.; VALLE, D. Aedes aegypti: histórico do controle no Brasil. Epidemiologia e Serviços de Saúde, 16 (2): 113-118, 2007.

BRASIL, Ministério da Saúde. Diretrizes Nacionais para a Prevenção e Controle de Epidemias de Dengue. Secretaria de Vigilância em Saúde, p. 1 - 162, 2009.

BRASIL, Ministério da Saúde. Programa Nacional de Controle da Dengue. Vigilância Epidemiológica, p. 1-34, 2002.

BRASIL, Ministério da Saúde. Vigilância em Saúde no Brasil 2003|2019. Secretaria de Vigilancia em Saúde, p. 1 - 154, 2019.

BRASSOLATTI, R. C.; ANDRADE, C. F.S. Avaliação de uma intervenção educativa na prevenção da dengue. Ciência \& Saúde Coletiva, 7(2):243-251, 2002.

CÂMARA, A. M. C. S. et al. Percepção do Processo Saúde-doença: Significados e Valores da Educação em Saúde. Rev. Bras. Educ. Médica. 40 (36): 40-50; 2012.

CANTARELLI, N.; FERRAZ, D. F. Uma possibilidade didática ao ensino da dengue no Ensino Fundamental. Programa de Desenvolvimento Educacional. Universidade Estadual do Oeste do Paraná, 2012.

CAPRARA, A. et al. Entomological impact and social participation in dengue control: a cluster randomized trial in Fortaleza, Brazil. Trans. R. Soc. Trop. Med. Hyg. 109: 99-105, 2015.

CAREGNATO, F. F. et al. Educação Ambiental como estratégia de prevenção à dengue no bairro do Arquipélago, Porto Alegre, RS, Brasil. Revista Brasileira de Biociências, Porto Alegre, 6 (2): 131-136, 2008.

CHIARAVALLOTI-NETO, F. Conhecimentos da população sobre dengue, seus vetores e medidas de controle em São José do Rio Preto, São Paulo. Cad. Saúde Pública, v. 13, n. 3, p. $447-453,1997$

CLARO, L. B. L.; TOMASSINI, H. C. B.; ROSA, M. L. G. Prevenção e controle do dengue: uma revisão de estudos sobre conhecimentos, crenças e práticas da população Cad. Saúde Pública, Rio de Janeiro, 20(6):1447-1457, 2004.

CODEÇO, C. T. et al. Surveillance of Aedes aegypti: Comparison of House Index with Four Alternative Traps. PLoS Neglected Tropical Diseases, 9 (2): e0003475, 2015.

CONSOLI, R. A. G. B.; LOURENÇO-DE-OLIVEIRA, R. Principais Mosquitos de Importância Sanitária no Brasil. Rio de Janeiro - Fiocruz. 228p. 1994.

CRUZ-BORGES, P. F. Monitoramento e controle de mosquitos vetores: uma proposta para avançar no conhecimento e no controle de Aedes aegypti e Aedes albopictus. Tese de Doutorado, Instituto Oswaldo Cruz, Fiocruz, Rio de Janeiro, 2018. 
DONALÍSIO, M. R.; GLASSER, C. M. Vigilância Entomológica e Controle de Vetores do Dengue. Rev Bras Epidemiol, 5 (3): 259-272, 2002.

ESTEVEZ, C. L. Elaboração de recursos didático-pedagógicos no estudo de insetos vetores de doenças. Programa de Desenvolvimento Educacional, Universidade do Maringá, 2016.

FONSECA, I. R.; LISBOA, D. K. M.; MARISCO, G. Estratégias didáticas alternativas sobre educação em saúde destinadas a estudantes da educação básica. Braz. J. of Develop., 6 (6):39360-39370, 2020.

FORATTINI, O. P. Culicidologia médica: identificação, biologia e epidemiologia. São Paulo: 2002, 2002.

GOHN, M. G. Empoderamento e participação da comunidade em políticas sociais. Saúde e Sociedade, 13 (2): 20-31, 2004.

INSTITUTO OSWALDO CRUZ. 10 Minutos Contra a Dengue. Disponível em: <http://www.fiocruz.br/ioc/cgi/cgilua.exe/sys/start.htm?from\%5Finfo\%5Findex=41\&i nfoid=1127\&sid=32> . Acesso em: 29 de abril de 2021.

KRAEMER, M. U. et al. The global distribution of the arbovirus vectors Aedes aegypti and Aedes albopictus. eLife. 4: e08347. 2015.

LIMA, E. C.; VILASBÔAS, A. L. Q. Implantação das ações intersetoriais de mobilização social para o controle da dengue na Bahia, Brasil. Cad. Saúde Pública, Rio de Janeiro, 27(8):1507-1519, 2011.

MACHADO, L. F. Emprego de atividades lúdicas na educação em saúde voltadas ao controle de Aedes (Stegomyia) aegypti (Linnaeus, 1762), e prevenção da Dengue, Zika e Chikungunya: uma revisão integrativa. Dissertação - Instituto Oswaldo Cruz, Fiocruz, Rio de Janeiro. 80 p. 2019.

MARTEIS, L. S.; MAKOWSKI, L. S.; SANTOS, R. L. C. Santos. Abordagem sobre Dengue na educação básica em Sergipe: análise de cartilhas educativas Scientia Plena 7, 2011.

MEDEIROS, R. H. A. 0 ensino de promoção e educação em saúde para sanitaristas. Com. Saúde e Educação. 22(65):609-19, 2018.

PAULA, C. R. et al. "Arte em defesa da vida": estratégia educativa de vigilância em saúde "Art in defense of life": health surveillance educational strategy. Em Extensão, Uberlândia, 19 (1): 72-183, 2020.

POWELL, J. R.; TABACHNICK, W. J. History of domestication and spread of Aedes aegypti A Review. Memorias do Instituto Oswaldo Cruz, 108: 11-17, 2013.

RANGEL, M. L. Dengue: educação, comunicação e mobilização na perspectiva do controle - propostas inovadoras, 12 (25): 433-41, 2008.

ROBERTO, S. Sequência didática sobre dengue: uma proposta pedagógica desenvolvida no $5^{0}$ ano do Ensino Fundamental. Dissertação, Universidade Estadual de Campinas, 2016. 
SANTOS-GOUW, A. M.; BIZZO, N. A dengue na escola: contribuições para a educação em saúde da implementação de um projeto de ensino de ciências. Encontro nacional de pesquisa em educação em ciências. Anais do VII Enpec. 2009.

SILVA, E. L. et al. Prevenção da Dengue: Experiências Escolares. PECIBES, 2: 66-73, 2017.

SILVA, I. B.; MALLMANN, D. G.; VASCONCELOS, E. M. R. Estratégias de combate à dengue através da educação em saúde: uma revisão integrativa. Saúde, Santa Maria, 41 (2): 27 $34,2015$.

SILVA, L. B. et al. Comunicação sazonal sobre a dengue em grupos socioeducativos na atenção primária à saúde. Rev. Saúde Pública. 45 (6):1160-1167, 2011.

[35] SILVA, L. F.; DAROSCI, A. A. B.; ALMEIDA, J. A. A Educação Ambiental como ação educativa no combate à dengue no município de Araguaína-TO. VII Connepi, 2012.

TAUIL, P. L. Urbanização e ecologia do dengue. Cad. Saúde Pública, Rio de Janeiro, 17:99102,2001

SOUZA-NETO, J. A.; POWELL, J. R.; BONIZZONI, M. Aedes aegypti vector competence studies: A review. Infect Genet Evol. 67: 191-209. 2019.

VALLE, D. Sem bala mágica: cidadania e participação social no controle de Aedes aegypti. Epidemiol. Serv. Saúde, Brasília, 25(3):629-632, 2016.

VIEIRA, B. R.; SANTOS, B. V. N.; OLIVEIRA, W. M. Mobilização social na escola: ações de prevenção e combate à dengue. Uberaba, Minas Gerais. 2015.

ZARA, A. et al. Estratégias de controle do Aedes aegypti: uma revisão. Epidemio, 25 (2): 391-404, 2016. 


\section{Capítulo 4}

\section{A formação do educador e os aspectos voltados para o exercício da docência no Ensino Superior}

\section{Karine Garcez Mc Comb \\ Francimeire Gomes Pinheiro}

Resumo: A formação de docentes universitários tem sido objeto de pesquisas e estudos, indicando a necessidade de análises que se afastem da concepção meramente técnica. Diante da problemática, o objetivo do artigo foi verificar como a formação o docente prepara o professor para a prática educacional, iniciando analisando as motivações que levam à escolha da docência; investigando quais características da graduação são essenciais para o exercício da docência e, por fim, apresentando as competências, habilidades e capacidades do ensino superior. A atividade de ensinar diária exige decisões imediatas, passando pela relação professor-aluno, voltada ao saber, raciocínio logico e a formação de pessoas. Autores alertam que durante a formação dos professores, deve-se considerar a importância dos saberes das áreas desconhecimento, pedagógicos, didáticos e dos saberes da experiência do sujeito professor. 0 docente de graduação não é meramente um professor, sua preparação é para ser também pesquisador. Os programas de pós-graduação, voltados para a metodologia do ensino superior, tendem a focar suas prioridades para se conduzir pesquisas. Formar docentes universitários implica na compreensão da importância do papel da docência, fornecendo aprofundamento científico-pedagógico, capacitando estes a enfrentar questões fundamentais da universidade como instituição social, uma prática social que implica as ideias de formação, reflexão, crítica.

Palavras-chave: Educação superior, Atividades pedagógicas, Desenvolvimento profissional 


\section{INTRODUCĈ̃O}

0 exercício da docência no ensino superior é uma atividade complexa que exige diversos saberes, indo muito além dos conhecimentos específicos da área escolhida para atuação do mesmo (SLOMSKI et al., 2020). Na década de 80 intensificou-se o movimento em prol da profissionalização do ensino e, com isso, o apelo para a constituição de um repertório de conhecimentos docentes. Os estudos desenvolvidos (ZEICHNER, 2000, 2009) contribuíram para o surgimento de novas perspectivas sobre a temática da formação docente e para a compreensão da docência como profissão. Para Calderhead (1988, p. 22), os professores são agentes ativos na construção de sua própria prática, pois, pelo fato de estarem em "interação com os demais e imersos na cultura institucional, adquirem e utilizam um corpo de conhecimentos em suas atividades docentes".

As demandas internas e externas da instituição exigem cada vez mais dos docentes se apropriarem de novos saberes, adquirindo novas competências para poderem lidar e agir diante de inúmeras situações iminentes do seu cotidiano (SANTOS e FIGHERA, 2012). Isso motiva e impulsiona os docentes a revisarem continuamente suas propostas e suas estratégias de atuação. Mas, para tornar a classe de professores mais organizada, é necessário pensar não apenas nos aspectos organizacionais, mas também na formação de tal profissional.

Portanto, nesse contexto, a formação docente pode ser concebida em duas etapas, como inicial e continuada, ou seja, um início de muitos saberes que virão, uma vez que, de acordo com Pacheco e Flores (1999), uma complementa a outra e estão vinculadas ao desenvolvimento profissional.

Os processos auxiliares da formação de professores vêm sendo foco de estudos por investigadores que buscam melhor compreender o desenvolvimento profissional docente e a apontam como uma nova vertente de preocupação (MARTINS e THEOPHILO, 2009). Porém, além da aquisição e do desenvolvimento de competências na situação de trabalho, a formação continuada também tem o objetivo de promover inovações educacionais. Mas, para que esse processo se concretize, os próprios docentes precisam de determinada organização do contexto escolar, que compreende questões pessoais, profissionais e organizacionais (LAFFIN, 2015).

Surgindo assim a problemática do estudo: Como a formação do educador de ensino superior o prepara para sua atuação profissional?

Diante da problemática, o objetivo do artigo foi verificar como a formação o docente prepara o professor para a prática educacional, iniciando analisando as motivações que levam à escolha da docência; investigando quais características da graduação são essenciais para o exercício da docência e, por fim, apresentando as competências, habilidades e capacidades do ensino superior.

\section{REFERENCIAL TEÓRICO}

\subsection{CONTEXTUALIZANDO A DOCÊNCIA}

Atualmente existe uma deficiência na formação do docente, sendo a prática o espaço para aquisição de conhecimento pedagógica e didática. A formação docente para o ensino superior surge perante a uma série de professores já atuantes ou que buscam nele ingressar e que, perante o mercado emergente gerado pelas políticas de expansão 
do mesmo, se ressentem de uma formação pedagógica mais consistente para o exercício da prática docente. A mudança ocorrida nos sistemas educacionais com o uso das tecnologias mediáticas vem reforçar a importância do professor planejar o trabalho pedagógico, aspectos que também serão tratados no âmbito do curso.

Ramalho, (2006) descreve que a relação entre o educador e o educando e os diversos fatores que permeiam essa relação complexa, aparenta ainda estar obscura ou mesmo pouco revelada, já que nota-se pouco investimento na discussão da temática e na formação didático-pedagógica dos professores iniciantes ou veteranos.

Ressalta-se a importância da abordagem, visto que é de suma importância trabalhar no desenvolvimento docente mostrando este as instituições que aplicam o ensino. Cada vez é maior o número de profissionais sem licenciatura atuando na carreira do magistério. Estatísticos lecionando Matemática, Farmacêuticos lecionando Química, Fisioterapeutas atuando como professores de Biologia e assim por diante (BEJARANO e CARVALHO, 2003; MAGALHÃES JUNIOR e PIETROCOLA, 2011).

\subsection{FORMAÇÃO DO DOCENTE}

A formação de docentes universitários, quanto ao sentido de qualificação científica e pedagógica, é um dos fatores básicos da qualidade da universidade e este tem sido um dos fatores explicativos do aumento progressivo de Programas de Formação Continuada nesta área. Algumas pesquisas publicadas de autores como Cunha (2006), Tardif (2002) e Pimenta e Anastasiou (2002), ressaltam que diversos professores possuem durante a sua formação pedagógica e ao atuar como docente, falhas em adotar e utilizar metodologias novas, estratégias diferentes, bem como outros materiais para apoio em suas aulas. Os professores, quando chegam à docência na Universidade, trazem consigo inúmeras e variadas experiências do que é ser professor.

Portanto, o contexto profissional está interligado ao progresso da carreira, à satisfação profissional, ao sentimento de pertencer ao grupo profissional e à valorização de seu currículo. No que tange à questão pessoal, corresponde ao autodesenvolvimento e adquirir status perante a sociedade.

A questão organizacional busca a adequação das mudanças sociais, econômicas e tecnológicas do mundo que o professor deverá entender para ensinar.

\footnotetext{
Pode ser congruente com a ideia de formação continuada, se considerarmos a ação de capacitar no sentido de tornar capaz, habilitar, uma vez que, para exercer sua função de educadora, a pessoa necessita adquirir as condições de desempenho próprias à profissão, ou seja, se tornar capaz. No entanto, a adoção da concepção de capacitação como convencimento e persuasão se mostra inadequada para ações de formação continuada, uma vez que os profissionais da Educação não podem e não devem ser persuadidos ou convencidos sobre ideias, mas sim conhecê-las, analisá-las, criticá-las ou até mesmo aceitá-las (ALTENFELDER, 2005).
}

Por fim, torna-se extremamente necessário que o profissional de ênfase ao processo de formação por meio da educação continua proporcionando à esse docente novos conhecimentos, pautando-se em uma atualização permanente. 


\section{MATERIAL E MÉTODOS}

A metodologia utilizada para o desenvolvimento do estuo foi a pesquisa bibliográfica, explicativa, qualitativa, por meio de material já publicado em livros, artigos, periódicos e meios eletrônicos, quanto à natureza é básica, uma vez que objetiva gerar novos conhecimentos, úteis para o avanço da ciência, sem aplicação prática prevista. Passa a ser qualitativa quanto ao método de abordagem, pois não requer o uso de métodos e técnicas estatísticas e exploratória quanto à realização dos objetivos, uma vez que pouco conhecimento tinha sobre o assunto pesquisado (GIL, 2016).

Buscou-se reunir informações acerca da formação do docente para o ensino superior, apontando a sua importância, caracterizada pelas competências, habilidades e capacidades que levam a escolha da docência como profissão. Para tanto utilizou-se como embasamento teórico os estudos de vários autores como: Fernandes (2004), Moran (2000), Cunha (2006) entre outros.

\section{RESULTADOS E DISCUSSÃO}

\subsection{ESCOLHA DA DOCÊNCIA - MOTIVAÇÃO}

Executar a docência é uma tarefa onde o princípio principal é a formação sólida, esta não somente de conteúdos científicos referentes a disciplina em estudo, mas também no que corresponde a sua didática como um todo e a variantes mudanças características da docência, tais como a atualização constante e preparação (ROSSI e HUNGER, 2012).

De outro modo, destaca-se o ensino. Necessita-se obter um reconhecimento quanto o ponto de vista do docente, perante as atividades de ensino, no qual está permeia habilidades, conhecimento, disponibilidade, atitudes mentais, basicamente diferentes das necessárias ao pesquisador. Ensinar exige saber, reporta-se a uma atividade formal e intencional, assim como os objetivos que deverão ser alcançados. Exercer a docência significa ter uma formação sólida, além da base cientifica por meio de conteúdos próprios disciplinares, requer aspectos didáticos, como um todo (LEMKE, IENKE, 2014).

A escolha da carreira docente é cheia de emoção, uma vez que pode ser inspirada no trabalho de pessoas queridas, encantamento com professores da infância, sentimento de vocação desde pequenos ou mesmo para aqueles que chegaram por caminhos tortuosos, a permanência na profissão vem acompanhada de paixão.

Em sua bagagem histórica a arte de ensinar se constitui como um desafio para a profissão docente, não pelo fato de se configurar como uma atividade que requer um planejamento anterior ou uma preparação específica em relação a conteúdos e visão curricular fixado no ensino para desenvolver habilidades e competências, isso numa perspectiva de construção da identidade docente dentro de uma discussão mais elaborada e de superação do estigma do professor como um técnico que ensina conteúdo. 0 papel do docente é maior e essa conscientização se constitui dentro de um projeto também maior, que envolve os saberes (KLEIMAN, 2001).

Ser professor para muitos é uma oportunidade de estar sempre aprendendo, pois o contato com os alunos propicia uma constante renovação, porque eles estão abertos a conhecer o mundo. 0 professor pode fazer do seu trabalho em sala um espaço de transformação enquanto sujeito que não reproduz apenas, mas que produz seu 
conhecimento através de uma reflexão crítica.

De acordo com Galbraith (1992), a opção de escolha por carreiras atípicas para seu gênero, como a docência, pode servir de base para intervenções e aumento do alcance das opções profissionais a ser consideradas pelos jovens, e assim reduzira segregação a certas profissões.

A inspiração de um professor de infância também leva educadores a optar pela carreira pelo resto da vida. Segundo Rabelo (2010, p. 165):

As motivações da escolha profissional dos professores são influenciadas por fatores extrínsecos a profissão (relacionados com o contexto dessa atividade, como a empregabilidade; rentabilidade; necessidade de emprego e a falta de oportunidades; falta de opção; a melhor escolha possível; entre outras) e por fatores intrínsecos a profissão, como o gosto pela profissão e pela transmissão de conhecimento; o gosto por crianças; a busca quase utópica da transformação da sociedade; a escolha motivada pelo exemplo da família, de um amigo ou de um professor; a escolha profissional causada por desejo de liberdade e autoridade.

Para se manter na área por tanto tempo, mesmo recebendo propostas de empresas, até mesmo mais atrativas financeiramente, as pessoas podem se modificar com um processo de educação de qualidade.

Mas, ressalte-se que a escolha profissional não é uma decisão exclusivamente individual, mas vinculada a diversos fatores; por isso, os professores podem ressaltar o gosto pela profissão como principal motivador para a opção pelo magistério, mas não deixam de destacar outros aspectos como influência da família, questões econômicas, gosto por crianças e um desejo de transformar (FERNANDES, 2004).

Para Jesus (2002, p.61-62), dentre os fatores de escolha profissional bem como de motivação, existem os fatores extrínsecos e intrínsecos, e explica que os:

Fatores extrínsecos São aqueles relativos ao contexto dessa atividade; são as motivações ativas ou negativas, como a falta de opção, a melhor escolha possível, entre outras, e os fatores intrínsecos, aqueles que dizem respeito ao conteúdo das tarefas que o professor realiza na sua atividade profissional; são as motivações ativas e positivas de escolha profissional. Na sua análise, são sobretudo os fatores intrínsecos à atividade docente que mais influenciam a escolha desta profissão, nomeadamente o gostar de ensinar e de contribuir para o desenvolvimento dos alunos.

Gonçalves (2000), cita que há uma relação de intercâmbio entre as fontes intrínsecas e extrínsecas da motivação, que leva o indivíduo a não escolher uma atividade ou profissão intrinsecamente motivante, desde que sujeito a fortes razões como de natureza econômica, social e cultural, consideradas extrínsecas não favoreçam tal escolha.

Sendo assim, para o professor que fizer sua escolha profissional por motivos intrínsecos, provavelmente, ou ele não teve consciência dos fatores extrínsecos associados a ela, ou então estes não foram considerados desfavoráveis. Ou ainda a motivação intrínseca era tão forte que se sobrepôs aos seus fatores negativos.

No entanto, embora a escolha pela docência tenha sido feita por motivações intrínsecas ou extrínsecas existem características distintas e essenciais da graduação para o exercício da profissão. 


\subsection{CARACTERÍSTICAS ESSENCIAIS DA GRADUAÇÃO PARA O EXERCÍCIO DA DOCÊNCIA}

Nos últimos anos a formação e o desenvolvimento profissional de professores tem sido um dos temas mais presentes na investigação educacional. Esses estudos se multiplicaram e isso, em boa parte, se deve à implementação, em vários países do mundo, das reformas educativas realizadas para fazer frente a exigências postas pelas transformações econômicas, sociais e políticas no mundo globalizado.

A docência para o ensino superior, área pouco investigada no campo da didática, passou a merecer mais atenção de estudiosos, dado que as mudanças no sistema de formação e qualificação profissional para o mercado de trabalho estariam exigindo melhorias no ensino superior e no desempenho acadêmico das instituições e, em decorrência, no desempenho dos docentes universitários.

Existe uma preocupação, segundo Moran (2000), em torno da necessidade de enfrentar mudanças significativas que vêm ocorrendo na organização políticoadministrativa, social, educacional e cultural dos países, decorrentes dos avanços científicos e tecnológicos e do processo de mundialização leva-nos a ponderar sobre uma educação ao mesmo tempo planetária, globalizante e garantidora dos espaços locais.

Este autor afirma ainda que o "campo da educação está muito pressionado por mudanças, assim como acontece com as demais organizações. Percebe-se que a educação tem sido colocada como um dos caminhos viáveis para transformar a sociedade" (MORAN, 2000, p. 11).

Segundo Cunha (2006), a importância que a qualificação profissional dos professores adquiriu nos últimos anos, com vistas à melhoria da qualidade do ensino, tem levado a discussões, debates e pesquisas sobre uma nova educação escolar e a construção de um novo perfil profissional do professor. Amplos questionamentos têm sido feitos sobre os cursos de licenciatura, desde a década de 70 e continuaram nas décadas de 80 e 90, com os encontros e publicações com discussões sobre formação profissional, ressaltando o tema dos saberes e competências ou saberes dos professores.

$\mathrm{Na}$ realidade, esses professores desenvolvem diversas funções, estes que ultrapassam o exercício da docência. Ter conhecimento sobre a área atuante, bem como saber abordá-la vêm se tornando mais holísticas ao passar dos anos e com o surgimento de novas condições de trabalho.

Expõe-se às escolas e aos professores a articulação de uma educação que atenda às demandas e necessidades sociais, além dos processos de desenvolvimento em sentido transformador, de modo que o aquisição do conhecimento geral e específico, sejam agregados ao desenvolvimento de aptidões e habilidades que tornem os alunos competentes para enfrentar diferentes situações e assim possam desenvolver-se como pessoas, como cidadãos críticos e participativos cuja atuação se traduza em competência, dignidade e responsabilidade na sociedade em que vivem.

\subsection{DOCÊNCIAS DO ENSINO SUPERIOR - COMPETÊNCIAS, HABILIDADES E CAPACIDADES}

O ensino como matriz de referência para a construção do conhecimento e, por sua vez, como um ponto de grande relevância a formação profissional, se apresenta como 
uma questão de estudo, especificamente quando se questiona os aspectos: qualidade de ensino, formação para a autonomia ou mercado formação profissional, formação técnica, além de temáticas que referenciam a qualidade do profissional (PIMENTA, 2006).

A preocupação com a formação do professor para o ensino superior, em muitos casos, se dá com relação à questão da docência, com grande foco nas licenciaturas nos cursos que formam professores, pela necessidade de que sejam implementadas mais pesquisas de forma a investigar, precipuamente as problemáticas voltadas para a construção da identidade e profissionalidade docente dos futuros professores.

Diversos estudos de autores como Pimenta (2002), referem-se à formação e preparação do docente para o exercício no ensino superior sustentam e afirmam que pouca atenção é dada a este segmento de ensino. E Morosini, (2001) corrobora com essa ideia quando analisa que a legislação de educação superior apresenta limites quanto à formação didática do professor, constituindo-se, este, num campo de silêncio.

Mediante essas razões relacionadas a formação do docente bacharel que executa o exercício profissional na docência universitária, passou a ser destaque em diversas pesquisas, esclarecendo que estes demonstram maiores dificuldades profissionais, com resultados negativos quanto a qualidade de ensino e de trabalho.

Tais professores são formados em cursos que não contemplam em sua matriz curricular os conteúdos e metodologias voltados às atividades de ensinar e aprender. Ou seja, são bacharéis professores, mas não contam com a formação mínima para a docência, além disso, não se interessam pela formação continuada para sua categoria. Esse quadro é o resultado de formação deficitária para a profissão docente, e consequentemente muito pouco contribui para a formação profissional dos alunos.

Nesse cenário, importa conhecer e dominar os conteúdos e metodologias de desenvolvê-lo nas atividades de docência. Saber fazer, ou saber utilizar as metodologias adequadas para a compreensão dos conhecimentos necessários às aprendizagens deve ser a palavra de ordem para os bacharéis, mas que na maioria das vezes se detêm na supremacia do conhecimento dos conteúdos das disciplinas. Isso está bem explícito nas afirmações de que

\footnotetext{
A história registra que o professor, em especial nas áreas técnicas e humanas, por um largo período, era um profissional que, diferentemente dos professores do ensino fundamental e médio, não cuidava da sua formação pedagógica. 0 pressuposto para a tarefa de ensinar era o domínio de conhecimento, aqui entendido como saber específico sobre determinada área, condição suficiente para o exercício do magistério superior. (BARUFFI, 2000, p. 181)
}

A docência no ensino superior tem sofrido no quesito qualidade, e principalmente, de acordo com Tavares (2001), no que concerne a atuação em áreas específicas do conhecimento e que requer um mínimo de qualidade ou compromisso com a aprendizagem e a qualidade dessa aprendizagem as quais são referências em um determinado curso.

Tavares (2001), aponta que alguns fenômenos no ensino superior precisam ser estudados, enfatizando que estas áreas são de extrema necessidade para o desenvolvimento social e em especial da docência no ensino superior. Certamente a qualidade no ensino vai ser o reflexo da qualidade do profissional que nasce desse 
ensino e será parte da sociedade que é cheia de lacunas econômicas, sociais e também educacionais.

Nesse contexto, Torres (2002), enfatiza a necessidade de se equilibrar o conhecimento sobre a disciplina e a metodologia, bem como a forma de abordagem nas situações de ensino-aprendizagem quando afirma que:

\begin{abstract}
Para uma Educação Superior com qualidade profissional prescinde do conteúdo/forma técnica, na medida em que ela é entendida como instrumento pedagógico reflexivo, organizativo e contextualizado do trabalho pedagógico e como veiculadora e produtora de significados e sentidos sociopolíticos e culturais. (VALENTE, 1996, p. 32).
\end{abstract}

Ensinar para graduandos é um exercício complexo, devido sua constituição pedagógica, com variantes iniciando com o processo de esforço formado das necessidades de formação, até o esforço para adequação quanto as metodologias ideias para ensino, deixando historicamente resultados positivos quanto aos docentes de ensino superior e sua formação.

A docência do ensino superior se transforma num processo ambíguo, por que esta autonomia passa a ter limites diante dos investimentos internacionais. Cunha (2006), corrobora com esse pensamento quando afirma que a formação do professor universitário surge de um processo de relações internacionais política e econômica que incide numa qualidade específica, fruto de um sistema que escraviza essa relação, sendo outorgada pelo sistema de educação.

Cabe ao professor estabelecer um processo permanente de construção, elaboração, reflexão, análise crítica do contexto, reelaboração de concepções e produção de conhecimentos dos docentes. Para tanto, é necessário criar espaços e tempos para que o docente tenha condições de formação continuada. Ou seja, na ótica colaborativa, intercâmbio de conhecimentos, aprofundamento teórico, do investimento em estudos de pesquisa, além das vivências nas práticas institucionais.

Sendo assim, a aprendizagem do ser professor vai se desenvolvendo de um modo paulatino e inacabado. Mas, ressalte-se que essa conquista não pode acontecer somente de forma individual, há uma necessidade de fortalecimento das suas relações interpessoais.

Por fim, o que se constata atualmente são professores a procura de diversos mediadores e dispositivos de formação para a produção da docência. Os caminhos formativos por eles trilhados implicam ao atendimento das necessidades emergentes da sua atividade docente. Nessa busca de qualificação para a docência no ensino superior, os professores rememoram suas trajetórias pessoais e profissionais, procuram nas leituras, nos cursos de formação, na pesquisa, na interação com outros elementos que sejam substratos propulsores da constituição de novas aprendizagens docentes.

\title{
5. CONCLUSÃO
}

Conclui-se que muitas informações, conhecimentos, habilidades e conceitos se fazem necessário para que o aluno possa chegar ao resultado final e isso certamente não pode ser desprezado e muitas vezes têm um maior valor significativo. A ideia de que 
para ser professor basta dominar muito bem um determinado conteúdo é coisa do passado, a realidade agora é outra e como docentes devemos ter em mente que a formação pedagógica também é de fundamental importância, pois as mudanças socioculturais vividas atualmente forçam uma revisão dos paradigmas que, até este momento vigoravam como forma correta de conhecimento, estabelecendo uma revisão de tudo quanto já se disse epistemologicamente. Importa, pois, pensar hoje a formação do professor no contexto destas fases de tantos questionamentos.

Formar docentes universitários implica na compreensão da importância do papel da docência, fornecendo aprofundamento científico-pedagógico, capacitando estes a enfrentar questões fundamentais da universidade como instituição social, uma prática social que implica as ideias de formação, reflexão, crítica.

Observa-se que para ser docente, o profissional precisa gostar de lecionar, estar motivado para o dia a dia de trabalho, buscar inspirações diárias pra o desenvolvimento das atividades, sejam estas as motivações intrínsecas ou extrínsecas.

Ocorreram algumas mudanças no sistema e formação e qualificação para se realizar o exercício da docência nos últimos anos, principalmente voltada a graduação destes, melhorando a qualidade de ensino, focada a uma nova educação escolar, atendendo a demanda, pra que estes exerçam a função positivamente e com competência.

Assim, verificou-se que a formação correta do docente prepara este na atuação como professor para a prática educacional. É de extrema importância a formação como docente em ensino superior para que seus resultados sejam positivos quanto ao ensino do educando, confirmando assim a hipótese proposta. 0 conhecimento quanto à área de atuação, o aprimoramento teórico, os investimentos em estudos por meio da educação continuada e a prática são vitais para a docência no Ensino Superior, formando profissionais qualificados.

\section{REFERENCIAS}

ALTENFELDER, Anna Helena. Desafios e tendências em formação continuada. Constr. psicopedag. v. 13, n. 10, 2005.

BARUFFI, Alaide Maria Zabloski. O Professor do ensino superior: realidade e desafios. Revista Jurídica UNIGRAN. Dourados, MS | v. 2 | n. 4 | jul./dez. 2000. P.181 - 188.

BEJARANO, N. R. R.; CARVALHO, A. M. P. Professor de ciências novato, suas crenças e conflitos. Investigações em Ensino de Ciências. v.8, n.3.p.1-15, 2003. Acesso em 03.01.2021, http://www.if.ufrgs.br/ienci/artigos/Artigo_ID107/ v8_n3_a2003.pdf.

CUNHA, M. I. (org) Reflexões e Práticas em Pedagogia Universitária. Campinas, SP: Papiros, 2006.

FERNANDES, Maria Cristina da Silveira Galan. Escolha profissional e pratica docente: o discurso de professores do ensino superior privado. Associação Nacional de Pósgraduação e Pesquisa em Educação, 2004. 
GALBRAITH, Michael. Escolhas de carreiracompreensão dos homensno ensino fundamental. Journal of Educational Research, U.K., v. 85, n. 4, p. 246-253, mar./abr. 1992.

GONCALVES, Jose Alberto. Ser professora do 1ํㅜ ciclo: uma carreira em analise. 2000.Tese (Doutorado em Ciências da Educação) - Programa de Pós-graduaçãoem Ciências da Educação, Faculdade de Psicologia e de Ciências da Educação, Universidade de Lisboa, Lisboa, 2000.

GIL, A.; C. Como elaborar projetos de pesquisa. 6. ed. São Paulo: Atlas, 184p. 2016.

JESUS, Saul Neves de. Motivação e formação de professores. Coimbra: Quarteto Editora,2002.

KLEIMAN, Ângela. A formação do professor. Campinas, SP: Mercado de Letras,2001, p.115-156.

LAFFIN, M. Graduação em Ciências Contábeis - a ênfase nas competências: Contribuições ao debate. Education Policy Analysis Archives/Archivos Analíticos de Políticas Educativas, 23, 1-27. https://doi.org/10.14507/epaa.v23.1844.2015.

LEMKE, Cibele Krause e IENKE, Ana Camila Gaspar. 0 processo de formação docente a partir da análise de relatórios de estágio supervisionado em língua espanhola. Revista Escrita. Vol. 5, pg. 251-265. 2014.

MAGALHÃES JUNIOR, C.A.O.; PIETROCOLA, M. Atuação de Professores Formados em Licenciatura Plena em Ciências. ALEXANDRIA Revista de Educação em Ciência e Tecnologia, v.4, n.1, p.175-198, 2011.

MARTINS, G. A.; THEOPHILO, C. R. Metodologia da investigação científica para Ciências Sociais Aplicadas. São Paulo: Atlas.2009.

MORAN, José Manuel. Novas tecnologias e mediação pedagógica. 6. ed. Campinas: Papirus, 2000.

MOROSINI, Marília Costa (org.) Professor do ensino superior: identidade, docência eformação. 2ª ed. Brasília: Plano Ed, 2001. p. 45-51

PACHECO, J.,\&FLORES, M. Formação e avaliação de professores. Porto: Porto Editora. 1999.

PIMENTA, Selma Garrido; ANASTASIOU, Léa das Graças Camargos. Docência no Ensino Superior. São Paulo: Cortez, 2002. (coleção Docência em Formação v. 1).

RABELO, Amanda Oliveira. "Eu gosto de ser professor e gosto de crianças" - A escolha profissional dos homens pela docência na escola primária. Revista Lusófona de Educação, 2010,15, 163-173.

RAMALHO, B.L. Reflexões sobre o ensino e o exercício da docência no ensino superior. ForGRAD em revista. Vitória, no․ 1, p.26-32, 2006. 
ROSSI, Fernanda; HUNGER, Dagmar. As etapas da carreira docente e o processo de formação continuada de professores de Educação Física. Rev. bras. educ. fís. esporte, São Paulo, v. 26, n. 2, p. 323-338, 2012.

SANTOS, E.A.; FIGHERA, A.C.M. A formação docente no ensino superior: processos formativos e aprendizagem da docência. IX ANPED SUL. Seminário em pesquisa em educação da região sul.2012.

SLOMSKI, V. G., ANASTÁCIO, J. B., ARAUJO, A. M. P. DE, SLOMSKI, V., \& CARVALHO, R. F. Casos da prática educativa na aprendizagem da docência universitária. Arquivos Analíticos de Políticas Educativas, 28(33). https://doi.org/10.14507/epaa.28.5041. 2020.

TAVARES, José. Construção do Conhecimento Profissional no Ensino Superior. Fortaleza: Demócrito Rocha, 2001.p. 17 -52.

TARDIF, M. Saberes docentes e formação profissional. Petrópolis, R.J.: Editora Vozes, 2002.

VALENTE, José Armando (Org.). O Professor no ambiente Logo - Formação e atuação. São Paulo - Campinas: NIED-CAMPINAS. 1996.

ZEICHNER, K. M. Uma agenda de pesquisa para a formação docente. Revista Brasileira de Pesquisa sobre Formação Docente, 1(1), 1-28.2009. 


\section{Capítulo 5}

A importância da equipe multidisciplinar para administração de nutrientes por via parenteral em Unidade de Terapia Intensiva - UTI

\section{Deivany de Souza Lima}

Francimeire Gomes Pinheiro

Bruno Bezerra Jensen

Resumo: 0 presente estudo trata-se de uma abordagem sobre a administração da terapia de nutrição parenteral em pacientes que estão internados em Unidade de Terapia Intensiva (UTI), enfatizando a importância da equipe multidisciplinar, incluindo médico, farmacêutico, nutricionista e enfermeiro como instrumento indispensável na recuperação dos enfermos. 0 mesmo tem como objetivo identificar os erros que ocorrem frequentemente em pacientes com situações de risco e a importância da equipe multidisciplinar sobre o cuidado dessa terapia. 0 estudo tem caráter de revisão de literatura utilizando as bases de dados eletrônicos Scielo, Periódico Capes, PubMed e Science Direct entre os anos de 2006 a 2016. Foram encontrados dezenove artigos relacionados aos erros de administração desta terapia nutricional em pacientes internados na UTI. No entanto, foi possível enumerar diferentes erros de dose, de vias de administração, de prescrições e o descuido da equipe multidisciplinar quanto a administração dessa terapia, já que os pacientes em UTI têm maior risco nutricional por seu estado de debilidade, necessitando mais atenção, principalmente por ser uma terapia que a via de administração é mais rápida e dificilmente reversível depois de administrada. Portanto, a equipe multidisciplinar é de extrema importância nesses casos, pois uma equipe bem treinada e preparada possibilitará a redução de erros e contribuirão com a reabilitação dos pacientes.

Palavras-chave: Nutrição alternativa; Interação medicamentosa; Segurança do paciente; Equipe multiprofissional. 


\section{INTRODUCĈ̃O}

A Unidade de Terapia Intensiva (UTI) constitui-se em um ambiente destinado ao tratamento de doentes em situação grave e crítica, que necessitam de cuidados complexos e monitoramento contínuo (SCHWONKE et al., 2011). Os principais motivos de internação dos pacientes na UTI são por insuficiência respiratória, seguido da instabilidade hemodinâmica, com uma taxa de mortalidade elevada entre aqueles com disfunção hemodinâmica, da mesma forma, um maior número de pacientes apresenta comorbidades associadas ao diagnóstico primário, dentre elas, a Hipertensão arterial, uma das mais expressivas, seguida pela Diabetes mellitus (VIEIRA, 2011).

Este ambiente, cada vez mais repleto de aparatos tecnológicos, vem permitindo aos profissionais de saúde maior controle das situações de risco, rapidez nas tomadas de decisões e agilidade no desempenho de ações mais efetivas em situações críticas (SCHWONKE et al., 2014).

Os pacientes submetidos à UTI, frequentemente, apresentam depleção nutricional já que a resposta metabólica ao estresse, conhecida como resposta de fase aguda, promove intenso catabolismo e mobilização de proteínas para reparo de tecidos lesados e fornecimento de energia (TEIXEIRA, CARUSO e SORIANO, 2006). Outro fator que se deve levar em consideração é que as doenças intercorrentes como infecções e procedimentos cirúrgicos podem levar à anorexia (FERNANDES e BEZERRA, 2006).

A dieta hospitalar está diretamente relacionada com o estado nutricional e recuperação do paciente, diminuindo assim, o tempo de internação (CASADO e BARBOSA, 2015). Por conseguinte, o fornecimento de calorias precisa ser de acordo com a condição clínica, pois é fundamental para o controle metabólico adequado do paciente crítico e está evidente que este é um instrumento fundamental na diminuição da morbimortalidade de pacientes críticos e na diminuição da taxa de permanência hospitalar. Além disso, há uma queda na taxa de infecção e uma melhora nos processos de cicatrização (FERREIRA, 2007; JÚNIOR et al., 2012).

Pacientes em terapia nutricional são extremamente vulneráveis e o cuidado nutricional deve ser prestado ao paciente em sua plenitude, tanto para prevenir quanto para reverter quadros de desnutrição e outros agravos relacionados à nutrição (SETA, 2010). Essa Terapia pode ser fornecida ao paciente na forma de Nutrição Enteral ou Parenteral (MATSUDA e MARIN, 2014). Contudo, diante de prejuízos importantes da absorção de nutrientes pelo trato digestório, recomenda-se a terapia nutricional por via parenteral, por meio da qual serão repostos os nutrientes necessários à sobrevivência (NOGUEIRA et al., 2013).

A nutrição parenteral (NP) é utilizada em pacientes impossibilitados de receber nutrição oral ou enteral, como em pacientes com casos de fístulas enterocutâneas, câncer, quando a patologia causa toxicidade gastrointestinal, pancreatite aguda, sepse abdominal e meningite (MENDES, MEDEIROS e PAULO, 2008; DUTRA e SAGRILLO, 2013). A mesma, segundo a portaria № 272, é uma solução ou emulsão, composta basicamente de carboidratos, aminoácidos, lipídios, vitaminas e minerais, estéril e apirogênica acondicionada em recipiente de vidro ou plástico, destinada à administração intravenosa em pacientes desnutridos ou não, em regime hospitalar, ambulatorial ou domiciliar, visando à síntese ou manutenção dos tecidos, órgãos ou sistemas (BRASIL, 1988).

A NP não é um método isento de riscos, pois a mesma apresenta, como 
complicação predominante, a hiperglicemia, e como qualquer terapia nutricional má administrada, a NP pode gerar grandes complicações e interferir negativamente na recuperação do paciente, podendo aumentar a morbidade, a permanência em UTI e até causar óbito (GARÓFOLO et al., 2007; CASTRÃO, FREITAS e ZABAN, 2009). Essa terapia deve abranger, obrigatoriamente, as seguintes etapas: indicação e prescrição médica, preparação (avaliação farmacêutica, manipulação, controle de qualidade, conservação e transporte), administração, controle clínico e laboratorial e, por fim, a avaliação final (BRASIL, 2009).

Além da ingestão diminuída, restrição de oferta hídrica, instabilidade hemodinâmica, diminuição da absorção e interação fármaco nutriente que podem ser situações de risco nutricional, a pouca atenção dos profissionais de saúde ao cuidado na dieta, pode levar à indicação inadequada, à falta de avaliação nutricional e à monitoração pouco frequente, contribuindo com o quadro de desnutrição (MAICÁ e SCHWEIGERT, 2008).

Conforme a RDC no 63, (2000), da Agência Nacional de Vigilância Sanitária (ANVISA), a Terapia de Nutricional Parenteral exige uma Equipe Multiprofissional de Terapia Nutricional (EMTN) como grupo formal e obrigatoriamente constituído de, pelo menos, um profissional médico, farmacêutico, enfermeiro e nutricionista, habilitados e com treinamento específico para a prática da TN. Sendo assim, torna-se essencial, em ambiente hospitalar, a instalação de meios de prevenção e minimização das complicações, por meio da constituição de equipes multidisciplinares e de estabelecimento de protocolos de conduta para essas terapias (CASTRÃO, FREITAS e ZABAN, 2009).

Dessa forma, esta revisão bibliográfica tem como objetivo de identificar os erros que ocorrem frequentemente em relação à administração de nutrientes por via parenteral em enfermos com situações críticas na Unidade de Terapia Intensiva e estudar a importância da equipe multidisciplinar sobre o cuidado desse recurso terapêutico garantindo a segurança do paciente.

\section{REFERENCIAL TEÓRICO}

\subsection{PAPEL DA EQUIPE MULTIDISCIPLINAR DE SAÚDE}

A constituição da equipe multidisciplinar em saúde vai além de diversas categorias profissionais, a qual ocorre uma interatividade de disciplinas e saberes, com o objetivo de integrar o conhecimento a partir da discussão entre os membros (MATUMOTO et al., 2005). Deve ser levado em consideração, que o alvo nessas reuniões é exatamente a busca pela reabilitação ou melhoria nas condições de vida do doente. Já que o trabalho em equipe se torna uma estratégia para a promoção de propostas inovadoras, no sentindo de equacionar processos em que cada integrante possa pontuar suas ações, associando com as opiniões dos demais participantes e priorizando esta comunicação para uma avaliação contínua e resolutiva (PINHO, 2006).

A equipe multiprofissional deve ser composta por médicos, enfermeiros, farmacêuticos, nutricionistas, fisioterapeutas, dentistas, entre outros. No entanto, para alcançar êxito nas devidas reuniões, é de suma importância que esses profissionais adotem uma postura reflexiva na prática do cuidar, visando a dignidade e segurança do paciente (ANCP, 2009). Logo, a capacidade de trabalho entre esses integrantes se torna 
um dos requisitos exigidos, para uma conduta cooperativista, responsável e participativa (RICCARDI et al. 2009).

\subsection{A SEGURANÇA DO PACIENTE}

A expressão "segurança do paciente" está associada na tomada de decisões planejadas para evitar, prevenir ou até mesmo otimizar resultados adversos e/ou erros acometidos pelos profissionais no âmbito assistencial que possam expor os pacientes aos riscos de diferentes graus, inclusive ao óbito. Logo, se faz necessário assegurar uma assistência de qualidade a estes indivíduos que estarão recebendo o atendimento hospitalar ou domiciliar (CAPUCHO; CASSIANI, 2013; RIGOBELLO et al., 2014; SILVA et al., 2016). Vale salientar que o número de erros no ambiente hospitalar é muito expressivo, já que o risco de infecção associado aos cuidados de saúde em alguns países em desenvolvimento é de aproximadamente 20 vezes maior do que em países desenvolvidos (BARROS, 2013).

A discussão sobre essa temática só recebeu atenção no final da década de 90, por meio de divulgação de sucessivas obras e uma delas foi "To err is human: Building a safer health system", elaborado pelo Comitê para a Qualidade do Cuidado à Saúde na América do Institute of Medicine of the National Academies (BARROS, 2013). Somente em 2004, que por meio do Programa da Aliança Mundial para Segurança do Paciente, foram estabelecidos diretrizes e estratégias para incentivar procedimentos que pudessem garantir a integridade do paciente. Inclusive, as condutas a serem tomadas deveriam ser prioritariamente a partir de pesquisas baseadas em evidências científicas que possibilitassem melhores resultados (BRASIL, 2009; SILVA et al., 2016).

Com o avançar histórico, vários programas foram implementados, principalmente os associados à novas tecnologias, que contribuem até hoje para a observação de eventos indesejados, falha na qualidade e segurança dos procedimentos no meio assistencial. Dessa forma, vem agregando para um tratamento mais seguro e eficaz. A partir dos recursos tecnológicos aplicados, as terapias apesar de serem complexas, são consideradas eficientes. Mas, mesmo assim apresentam riscos, o que requer domínio dos profissionais de saúde, principalmente os que atuam com pacientes de maior vulnerabilidade, como, os da Unidade de Terapia Intensiva (VICENT, 2010; TAVARES, 2003).

\subsection{INTERAÇÕES FÁRMACO-NUTRIENTES}

Na prática clínica não deve ser levado em consideração somente as interações entre os medicamentos, mas também as interações fármaco-alimento. Apesar de apresentarem um caráter teórico, pode ser desencadeado reações resultantes em efeitos relevantes na rotina hospitalar. Esses tipos de interações são muito comuns na evolução de pacientes hospitalizados, principalmente no setor da unidade de terapia intensiva, onde são indicados aos pacientes múltiplos medicamentos conforme as prescrições médicas (GAUTHIER e MALONE, 1998; HAMES et al., 2002; MOURA e REYES, 2002).

As interações entre medicamentos e nutrientes são bastantes complexas e podem determinar prejuízo na ação do medicamento e/ou alimento, como por exemplo, a presença de inadequado efeito farmacológico do medicamento ou comprometimento do estado nutricional do indivíduo, ocasionando aumento no custo e no período de internação hospitalar (HELDT e LOSS, 2013). A terapia nutricional pode ser 
administrada pela via enteral através de um tubo de alimentação ou pela via parenteral. Contudo, quando o enfermo se encontra muito debilitado, a recomendação é que os nutrientes sejam administrados pela via parenteral, que apesar de serem invasivas, são muito eficientes quanto ao tempo de ação, mas podem induzir reações indesejáveis quando não realizadas de forma adequada ou associada à alguns medicamentos que favorecem incompatibilidade (WILLIAMS, 2008; MASCARENHAS et al., 2015). Desse modo, esse recurso ainda precisa ser mais explorado com objetivo de usá-lo de forma correta e garantindo a segurança do paciente.

\section{MATERIAIS E MÉTODOS}

0 modelo de estudo trata-se de uma revisão de literatura e foi realizada utilizando as bases de dados eletrônicos Scielo (Scientific Eletronic Librery Online), PubMed, Science Direct e Periódico Capes, utilizando-se de artigos científicos, com as palavras-chave (Nutrição Parenteral, erros de administração por via parenteral, equipe multidisciplinar). Tendo como fator de inclusão, estudos relacionados com erros de administração de nutrientes por via parenteral em pacientes de unidade de terapia intensiva e a importância da equipe multidisciplinar para minimização dos erros na aplicação no período de 2006 a 2016. Foi considerado como critério de exclusão, o intervalo de tempo estudado, trabalhos com pacientes de outras unidades hospitalares, administração de nutrientes por via enteral e dissertações, teses e livros que abordem o tema proposto. A estratégia de busca pode ser visualizada no fluxograma (Figura 1).

Figura 1. Fluxograma da seleção de estudos para a revisão de literatura.

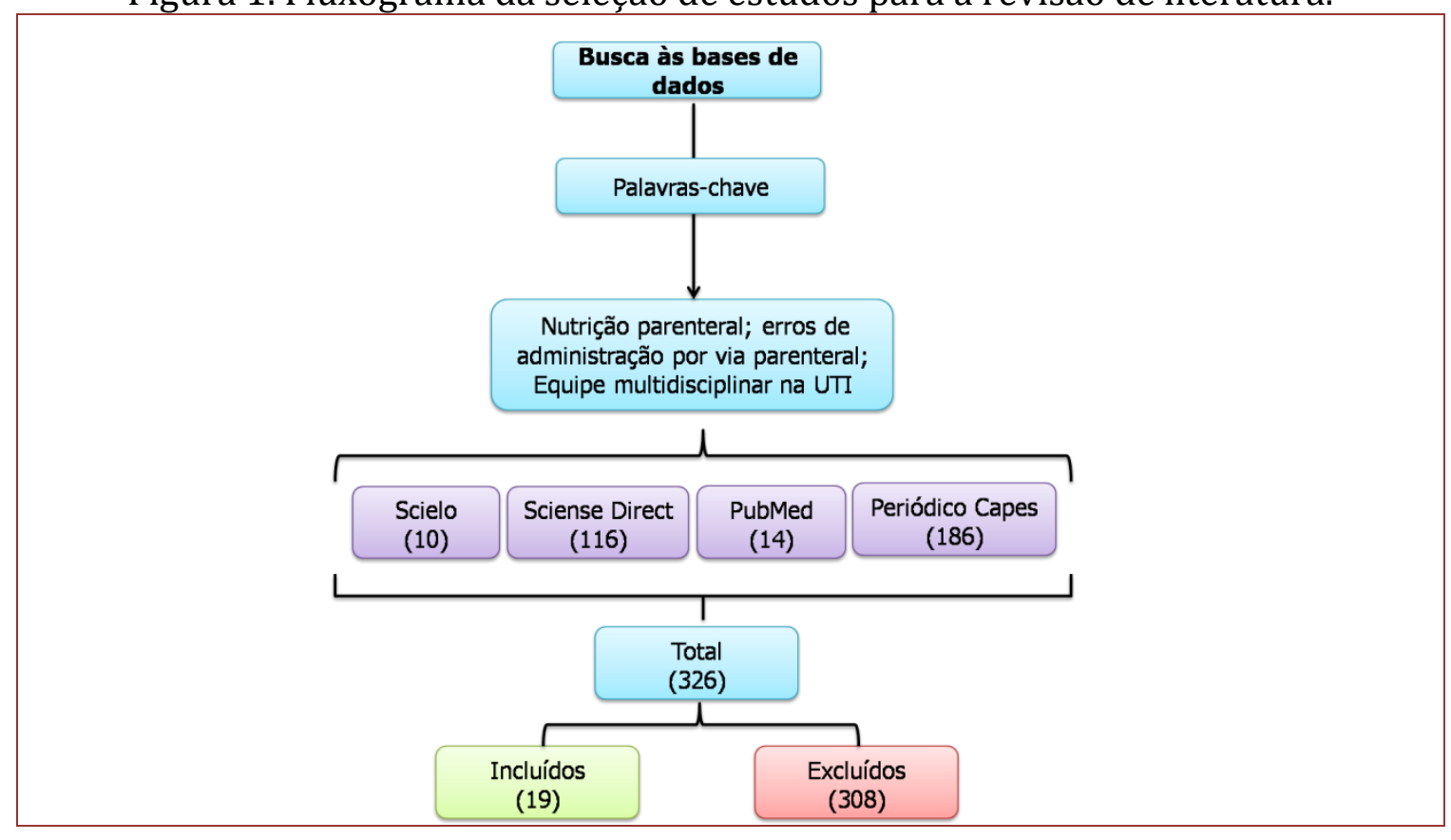

\section{RESULTADOS E DISCUSSÕES}

Foram encontradas 325 publicações, das quais 308 foram excluídas pelo fato de não corresponderem às plataformas de busca estabelecidas. Das pesquisas exclusas 80 eram publicações antes desse período e 245 não foram encontrados dados relacionados ao objetivo do estudo. 
De acordo com o levantamento nas bases de dados, foi possível identificar a escassez de artigos publicados quanto aos tipos de soluções nutritivas padrões mais indicados na administração por via parenteral, no entanto, o trabalho de Marchini et al., (1998), destaca os aminoácidos, glicose, emulsão lipídica, cloreto de sódio, cloreto de potássio, gluconato de cálcio, sulfato de magnésio, fosfato monobásico de potássio e oligoelementos.

O uso desses nutrientes por via parenteral deve ser estimado a partir do cálculo calórico dos pacientes, para que seja favorável para a sua reabilitação, por exemplo, o aporte proteico ajustado para $>1.2 \mathrm{~g} \cdot \mathrm{Kg}^{-1} \cdot \mathrm{d}^{-1}$ contribuiu com as reduções da morbidade e mortalidade (CUNHA et al., 2013). 0 estudo de Alberda et al. (2009), vem corroborar, a associação entre a oferta proteica e a calórica em um estudo multicêntrico com 2.772 pacientes, em 167 UTIs e em 37 países, onde observaram que a maior ingestão de energia e proteína estava diretamente relacionada com os melhores resultados clínicos de pacientes críticos.

0 tempo de início da terapia nutricional é um fator fundamental para os pacientes de UTI. 0 início precoce dessa terapia nutricional reduziu o tempo de internação de pacientes com sepse nessa unidade (SACON et al., 2011). 0 suporte nutricional do paciente grave é um dos maiores desafios clínicos e seus benefícios têm sido observados em pacientes pelo menos 50 a $65 \%$ das necessidades calóricas estimadas durante a primeira semana de internação (NUNES, 2011).

Kurihayashi et al. (2009), realizaram um estudo retrospectivo com o levantamento de pacientes admitidos na UTI do Hospital Universitário da Universidade de São Paulo, onde foi observado que, em pacientes cirúrgicos, iniciou-se a terapia nutricional parenteral em média de 109 horas, que possivelmente colaborou com o agravamento dos pacientes, mais uma vez colaborando o início da terapia de imediato.

Vale salientar que os pacientes em terapia nutricional devem ser monitorizados diariamente, para que seja avaliado o desempenho terapêutico, inclusive o acompanhamento de exames bioquímicos e discutidos pelos profissionais de saúde, gerando uma avaliação dos níveis fisiológicos (WAITZBERG et al., 2011). Backes et al. (2012) e Machado et al. (2006), realizaram um estudo com pacientes internados na UTI do hospital universitário da Universidade Federal de Santa Catarina, onde identificaram que a glicemia capilar, gasometria arterial e potássio sérico, foram os mais solicitados diariamente.

Embora não tenha descrito na literatura tantos trabalhos com abordagem dos tipos de erros que podem ocorrer em uma administração parenteral em pacientes de UTI, foram encontrados de acordo com o levantamento erros, sendo classificados por leves, moderados e graves (Tabela 1).

Uma das preocupações que, apesar de ter classificação moderada, é a questão da interação medicamentosa, pois, de acordo com Mascarenhas et al. (2015), pode favorecer interações fármaco nutriente, que são de certa forma comuns em pacientes que fazem uso de NP, mesmo em pacientes que usam vias distintas de acesso para fármaco e para medicamento.

A flebite, que é uma inflamação na veia, tem classificação grave devido a mesma, embora não comprometer o resultado terapêutico do medicamento, ter repercussões prejudiciais para o paciente, exigindo intervenções e até prolongamento do tempo de internação (SILVA e CAMERINE, 2012). o que pode retardar o seu processo de 
reabilitação e manter o paciente por mais tempo em Unidade de Terapia Intensiva.

Da mesma forma, foram encontrados artigos que abordam erros acometidos por profissionais que estão diretamente ligados com a administração da Nutrição Parenteral, feito uma tabela com os erros e o profissional que poderia evitar que tal problema acontecesse (Tabela 2). Tais erros, dependendo da gravidade do problema causado a partir da administração da nutrição parenteral, podem ser relevantes para o quadro clínico do paciente, que, geralmente, são àqueles que se encontram em situação de doença mais avançada, doenças essas, que levam os pacientes a estado de extrema debilitação, e o não-cuidado com a administração das nutrições, sejam elas orais, enterais ou parenterais, podem ajudar a agravar o quadro clínico dos mesmos levandoos a óbito.

Tabela 1. Erros mais frequentes na administração de nutrientes por via parenteral em pacientes de UTI.

\begin{tabular}{|c|c|c|c|c|}
\hline Tipo de erro & $\begin{array}{l}\text { Classificaç } \\
\text { ão }\end{array}$ & Nível & Autor (es) & Ano \\
\hline $\begin{array}{l}\text { Rótulos preenchidos de forma } \\
\text { incorreta }\end{array}$ & M & $\begin{array}{c}\text { Leve/ } \\
\text { Moderado }\end{array}$ & Mascarenhas et al. & 2015 \\
\hline Captopril x cloreto de potássio & IAM & Moderado & Guimarães et al. & 2012 \\
\hline $\begin{array}{llll}\text { Pancurônio } & \mathrm{x} & \text { sulfato } & \mathrm{de} \\
\text { magnésio } & & & \end{array}$ & IAM & Moderado & Guimarães et al. & 2012 \\
\hline $\begin{array}{l}\text { Hidroclorotiazida } \mathrm{x} \text { gluconato } \\
\text { de cálcio }\end{array}$ & IAM & Moderado & Guimarães et al. & 2012 \\
\hline Aciclovir & IAM & Moderado & Miranda e Ferraresi & 2016 \\
\hline Anfotericina B lipossomal & IAM & Moderado & Miranda e Ferraresi & 2016 \\
\hline Ceftriaxona & IAM & Moderado & Miranda e Ferraresi & 2016 \\
\hline Ganciclovir & IAM & Moderado & Miranda e Ferraresi & 2016 \\
\hline Flebite & M & Grave & Abdul-Hak e Barros & 2014 \\
\hline
\end{tabular}

IAM: Interação Alimento x Medicamento; M: Mecânico

O enfermeiro é o profissional responsável pela administração da NP, sendo assim, é imprescindível que o mesmo conheça seu papel em cada esfera de sua atuação, tenha conhecimento técnico - científico sobre as atividades ali realizadas (SANTOS et al., 2013) e que cumpra as suas obrigações de forma eficaz e eficiente, visando minimizar os riscos de infecção a nível hospitalar, e consequentemente, dentro da Unidade de terapia intensiva (MELO et al., 2016).

Pôde-se notar que as maiores quantidades de erros encontrados foram em relação à administração da NP por parte dos enfermeiros. Principalmente em relação à dosagem e o tipo de medicamento que está sendo administrado aos pacientes por parte dos mesmos (Silva et al., 2007; Filho, Praxedes e Pinheiro, 2011). Essa situação deve ser destacada porque, mesmo que não tenha um vasto número de artigos relatando os erros que são acometidos no momento da administração da NP, tal procedimento, sendo executado de modo errado, tanto na quantidade quanto na forma com que é administrado, principalmente em pacientes de UTI que já estão em situação crítica, pode trazer prejuízos irreversíveis ao seu estado.

É importante ressaltar que a equipe multidisciplinar possui o objetivo de proporcionar a reabilitação do paciente, mas se faz necessário, o desenvolvimento de um 
trabalho em conjunto, com a possibilidade de discutir a melhor forma para beneficiá-lo (BOLETA e JERICÓ, 2006).

Tabela 2. Erros de administração por via parenteral e profissionais que podem evitar o problema

\begin{tabular}{|l|l|l|l|l|}
\multicolumn{2}{|c|}{ Autor } & \multicolumn{1}{|c|}{ Ano } & \multicolumn{1}{c|}{$\begin{array}{c}\text { Problemas enfrentados na administração } \\
\text { poderia evitar o } \\
\text { problema }\end{array}$} \\
\hline Santos et al. & 2013 & $\begin{array}{l}\text { Falta de conhecimento sobre a via de acesso na } \\
\text { administração da nutrição parenteral. }\end{array}$ & ENFERMEIRO \\
\hline $\begin{array}{l}\text { Silva, Novaes e } \\
\text { Magalhães }\end{array}$ & 2014 & $\begin{array}{l}\text { Instabilidade de fármacos na nutrição } \\
\text { parenteral }\end{array}$ & FARMACÊUTICO \\
\hline Mascarenhas et al. & 2015 & $\begin{array}{l}\text { Via de acesso não exclusiva para a } \\
\text { administração da nutrição parenteral, sendo } \\
\text { utilizado o mesmo acesso para infusão de } \\
\text { medicamentos. }\end{array}$ & ENFERMEIRO \\
\hline Mascarenhas et al. & 2015 & $\begin{array}{l}\text { A administração da bolsa de NP não foi } \\
\text { realizada pelo enfermeiro. }\end{array}$ & ENFERMEIRO \\
\hline Mascarenhas et al. & 2015 & $\begin{array}{l}\text { Dados do rótulo e prescrição médica não } \\
\text { conferidos antes da administração. }\end{array}$ & ENFERMEIRO \\
\hline Mascarenhas et al. & 2015 & $\begin{array}{l}\text { A bolsa de NP deixada em temperatura } \\
\text { ambiente antes de ser infundida. }\end{array}$ & FARMACÊUTICO \\
\hline Garcia & 2006 & $\begin{array}{l}\text { Prescrição de dieta sem o conhecimento da } \\
\text { composição da mesma. }\end{array}$ & MÉDICO \\
\hline Seta et al. & 2010 & $\begin{array}{l}\text { Não realização da avaliação nutricional na } \\
\text { admissão dos pacientes, nem no decorrer da } \\
\text { internação. }\end{array}$ & NUTRICIONISTA \\
\hline
\end{tabular}

De acordo com Queiroz e Araújo, (2009), as diversas estratégias adotadas pelas equipes para efetivar seu trabalho, salientam-se as reuniões de equipe para discussão de caso, nas quais se formaliza a comunicação a equipe em complemento às interações informais ou por meio de outras modalidades. Assim, nessa ótica, considera-se que o trabalho em equipe multidisciplinar oferece uma ferramenta ímpar para o alcance de bons resultados terapêuticos (SILVA e SANTOS, 2006). Vale lembrar que todos os profissionais são importantes para melhoria do paciente, já que a filosofia de cuidado se objetiva em eliminar ou reduzir os problemas associados à enfermidade, valorizando a multidimensionalidade do ser humano (Silva et al., 2013).

\section{CONCLUSÃO}

A partir do estudo realizado, foi possível identificar a escassez de artigos relacionados aos erros acometidos pela equipe multidisciplinar na administração da nutrição parenteral, mesmo sendo um tema de grande importância, pois a nutrição parenteral é um tipo de terapia nutricional de rápida absorção e dificilmente reversível depois de aplicada, o que pode ocasionar problemas maiores ao paciente, podendo leválo ao agravamento até a óbito, dependendo do tipo e dose administrada.

Portanto, é importante ressaltar que a formação de uma equipe multidisciplinar altamente capacitada, colabora com a minimização dos erros ocorridos na terapia dos pacientes, pois pode evitar a quantidade de óbitos em relação aos erros da equipe e também, prolongar a vida do paciente. 


\section{REFERÊNCIAS}

ALBERDA, C.; GRAMLIC, H.L.; JONES, N.; JEEJEEBHOY, K.; DAY, A.G.; DHALIWAL, R.; HEYLAND, D.K. The relationship between nutritional intake and clinical outcomes in critically ill patients: results of an international multicenter observational study. Intensive Care Med. 35:1728-1737, 2009.

ANCP - Academia Nacional de Cuidados Paliativos. Manual de cuidados paliativos. 1a ed. Rio de Janeiro: Diagraphic; 2009.

BACKES, M.T.S.; ERDMANN, A.L.; BÜSCHER, A.; BACKES, D.S. O cuidado intensivo oferecido ao paciente no ambiente de Unidade de Terapia Intensiva. 2012.

BARROS, C.G. Segurança do paciente como prioridade nas organizações hospitalares. Albert Einstein, São Paulo, 2013.

BRASIL. Ministério da Saúde. Regulamento técnico para a Terapia de Nutrição Parenteral. Brasília, 1998.

BRASIL. Ministério da Saúde. Regulamento técnico para Terapia Nutricional Enteral. Brasília, 2000.

BRASIL. Ministério da Saúde. Segundo desafio global para a segurança do paciente: orientações para cirurgia segura da OMS. Rio de Janeiro: Ministério da Saúde, 2009.

CAPUCHO, H. C.; CASSIANI, S. H. B. Necessidade de implantar programa nacional de segurança do paciente no Brasil. Rev. Saúde Pública. 47 (4): 791-798, 2013.

CASADO, A.V.D.M.; BARBOSA, L.S. Aceitação de dieta hipossódica e estado nutricional de pacientes internados em hospital público de Goiânia. O Mundo da Saúde: São Paulo. 39(2):188-194, 2015.

CASTRÃO, D.L.L.; FREITAS, M.M.; ZABAN, A.L.R.S. Terapia nutricional enteral e parenteral: complicações em pacientes críticos - uma revisão de literatura. Com. Ciências Saúde. 20 (1): 65-74, 2009.

CUNHA, H.F.R.; ROCHA, E.E.M.; HISSA, M. Necessidades proteicas, morbidade e mortalidade no paciente grave: fundamentos e atualidades. Rev Bras Ter Intensiva. 25(1):49-55, 2013.

DUTRA, I.K.A.; SAGRILO, M.R. Terapia Nutricional de Pacientes Oncológicos com Caquexia. Ciência da Saúde, Santa Maria. 1(15): 155-169, 2014.

FERNANDES, A.C.; BEZERRA, O.M.P.A. Terapia nutricional na doença pulmonar obstrutiva crônica e suas complicações nutricionais. Journal Brazilian Peumonology. 32(5):461-71, 2006.

FERREIRA, I.K.C. Terapia Nutricional em Unidade de Terapia Intensiva. Rev. Bras. Ter. Intensiva. 1(19): 90-7, 2007.

GARÓFOLO, A.; BOIN, S.G.; MODESTO. P.C.; PETRILLI, A.S. Avaliação da eficiência da nutrição parenteral quanto à oferta de energia em pacientes oncológicos pediátricos. Rev. Nutr., Campinas, 20(2):181-190, 2007. 
GAUTHIER, I.; MALONE, M. Drug-food interactions in hospitalised patients. Methods of prevention. Drug Safety. 18(6):383-393, 1998.

HAMMES, J.A.; PFUETZENREITER, F.; SILVEIRA, F.; KOENIG, A.; WESTPHAL, G.A. Prevalência de potenciais interações medicamentosas droga-droga em unidades de terapia intensiva. Rev Bras Ter Intensiva. 20(4):349-354, 2008.

HELDT, T.; LOSS, S.H. Interação fármaco-nutriente em unidade de terapia intensiva: revisão da literatura e recomendação atuais. Ver. Bras. Ter. Intensiva. 25 (2): 162-167, 2013.

JÚNIOR, S.J.A.M.; SANTOS, O.F.; GOMES, M.R.L.; ANJOS, L.; CABRAL, F.; FERREIRA, P.L. Protocolos de Terapia Nutricional Enteral e Parenteral. Teresina, 2012.

KURIHAYASHI, A.Y.; CARUSO, L.; SORIANO, F.G. Terapia nutricional parenteral em UTI: aplicação dos indicadores de qualidade. O Mundo da Saúde, São Paulo. 33(4):480-487, 2009.

LEANDRO-MERHI, V.A.; SREBERNICH, S.M.; GONÇALVES, G.M.S.; AQUINO, J.L.B. Perda de peso hospitalar, dieta prescrita e aceitação de alimentos. Arq. Bras. Cir. Dig. 28(1):8-12, 2015.

MACHADO, F.O.; SILVA, F.S.P.; ARGENTE, J.S.; MORITZ, R.D. Avaliação da Necessidade da Solicitação de Exames Complementares para Pacientes Internados em Unidade de Terapia Intensiva de Hospital Universitário. Revista Brasileira de Terapia Intensiva. 18 (4), 2006.

MAICÁ, A.O.; SCHWEIGERT, I.D. Avaliação nutricional em pacientes graves. Rev Bras Ter Intensiva. 20(3):286-295, 2008.

MARCHINI, J.S.; OKANO, N.; CUPO, P.; PASSOS, N.M.R.R.S.; SAKAMOTO, L.M.; FILHO, A.B. Nutrição Parenteral - Princípios gerais, formulários de prescrição e monitorização. Ribeirão preto, 1998.

MASCARENHAS, M.B.J; BARROS, R.S.; MARTINS, B.C.C.; LOUREIRO, C.V.; ARAÚJO, T.D.V.; PONCIANO, A.M.S.; FONTELES, M.M.F. Soluções de nutrição parenteral neonatal em hospital de ensino Brasileiro: da indicação à administração. Ver. Bras. De Farmácia Hospitalar e Serviços de Saúde. 6(2): 18-23, 2015.

MASCARENHAS, M.P.; NETO, M.T.R.; SILVA, W.A.C.A. formação dos administradores para a sustentabilidade: A percepção do corpo discente das IES da RMBH. Revista Interdisciplinar Científica Aplicada, Blumenau. 9 (3): 57-75, 2015.

MATSUDA, I.L.A.; MARIN, M.L.M. Administração de medicamentos via sonda de Nutrição Enteral na prática clínica. São Camilo, 2014.

MATUMOTO, S.; FORTUNA, C.M.; MISHIMA, S.M.; PEREIRA, M.J.B.; DOMINGOS, N.A.M. Supervisão de equipes no Programa de Saúde da Família: reflexões acerca do desafio da produção de cuidados. Dossiê. Interface: Comunicação, Saúde, Educação. 9 (16): 9-24, 2005.

MENDES, A.S.; MEDEIROS P.A.D.; PAULO P.T.C. Perfil de pacientes submetidos à terapia de nutrição parenteral em um hospital público. Rev. Bras. Farm., v. 89, n. 4, p. 373- 375, 
2008.

MORAIS, G.; CHIARI, M.B.; GONÇALVES, M.I.R. Perfil de pacientes em uso de via alternativa de alimentação internados em um hospital geral. Rev. CEFAC. São Paulo. 15 (1), 2013 Epub Sep 18, 2012.

MOURA, M.R.; REYES, F.G. Interação fármaco-nutriente: uma revisão. Rev Nutr.15(2):223-238, 2002.

NOGUEIRA, S.C.J.; CARVALHO, A.P.C.; MELO, C.B.; SETAL, E.P.M.H.; O'DWYERL, G.; HENRIQUES, P.; SALES, G.L.P. Cuidado nutricional em hospitais públicos de quatro estados brasileiros: contribuições da avaliação em saúde à vigilância sanitária de serviços de saúde coletiva vol.15 supl. Rio de Janeiro. 2010.

NUNES, A.L.B.; KOTERBA, E.; ALVES, V.G.F.; ABRAHÃO, V.; CORREIA, M.I.T.D. Terapia Nutricional no Paciente Grave. Associação Brasileira de Nutrologia, 2011.

PINHO, M.C.G. Trabalho em equipe de saúde: limites e possibilidades de atuação eficaz. Ciência \& Cognição, Rio de Janeiro. 8: 68-87, 200.

RICCARDI, A.L.K.; LOPEZ, S.E.; ZANK, C.; BECHAR, P.A. 0 trabalho em equipe por meio de editor de texto coletivo. Novas Tecnologias na Educação. 7 (3): 1-11, 2009.

RIGOBELLO, M.C.G.; CARVALHO, R.E.F.L.; CASSIANI, S.H.B.; GALON, T.; CAPUCHO, H.C.; DE DEUS, N.N. Clima de segurança do paciente: percepção dos profissionais de enfermagem. Acta Paul Enferm. 25 (5): 2012.

SACON, M.F; CARDOSO, L.T.Q; CARRILHO, C.M.D.M.; KAUSS, I.A.M.; CARVALHO, L.M.; QUEIROZ, L.F.T.; GRION, C.M.C.; BONAMETTI, A.M. 0 início precoce do suporte nutricional como fator prognóstico para pacientes com sepse grave e choque séptico. Semina: Ciências Biológicas e da Saúde, Londrina. 32 (2): 135-142, 2011.

SCHWONKE, C.R.G.; LUNARDI, W.D.F.; SILVA, J.R.S. Ambiente de Ventilação Mecânica: uma reflexão possível. Revista Eletrônica trimestral de enfermagem. 35: 263-271, 2011.

SCHWONKE, C.R.G.B.; FILHO, W.D.L.; LUNARDI, V.L.; SANTOS, S.S.C.; BARLEM, E.L.D. Perspectivas filosóficas do uso da tecnologia no cuidado de enfermagem em terapia intensiva. Fundação Universidade do Rio Grande. Programa de Pós-graduação em Enfermagem. Rio Grande, 2011.

SCHWONKE, C.R.G.B; FILHO, W.D.L.; LUNARDI, V.L.; SANTOS, S.S.C.; BARLEM, E.L.D. Perspectivas filosóficas do uso da tecnologia no cuidado de enfermagem em terapia intensiva. Fundação Universidade do Rio Grande. Programa de Pós-graduação em Enfermagem. Rio Grande, 2011.

SILVA, A.C.A.; SILVA, J.F.; SANTOS, L.R.O.; AVELINO, V.S.D.; SANTOS, A.M.R.; PEREIRA, A.F.M. A segurança do paciente em âmbito hospitalar: Revisão integrativa da literatura. Revista Cogitare Enfermagem. 21: 1-9, 2016.

SILVA, L.D.; CAMERINI, F.G. Análise da administração de medicamentos intravenosos em hospital da rede sentinela. Florianópolis, 2012. 
TAVARES, V. H. Segurança do Paciente em Terapia Intensiva: Análise do Uso da Restrição Física. 2013. 129 p. Dissertação (Mestrado) - Departamento de Enfermagem, Faculdade de Ciências da Saúde, Universidade de Brasília, Brasília, 2013.

TEIXEIRA, A.C.C.T.; CARUSO, L.; SORIANO, F.G. Terapia Nutricional Enteral em Unidade de Terapia Intensiva: Infusão versus Necessidades. Revista Brasileira de Terapia Intensiva. 2006.

VIEIRA, M.S. Perfil geográfico e clínico de pacientes admitidos na UTI através da Central de Regulação de Internações Hospitalares. Comun. Ciênc. Saúde; 22(3): 201-210, 2012.

VINCENT, C. Segurança do paciente: orientações para evitar eventos adversos. 1 ed. São Caetano do Sul, SP: Yendis, 2010.

WAITZBERG, D.L.; ENCK, C.R.; MIYAHIRA, N.S.; MOURÃO, J.R.P.; FAIM, M.M.R.; OLISESKI, M.; BORGES, A. Terapia nutricional: indicadores de qualidade. Projeto diretrizes, $11 \mathrm{p}$. 2011.

WILLIAMS, N.T. Medication administration through enteral feeding tubes. Am J Health Syst Pharm.65(24):2347-2357, 2008. 


\section{Capítulo 6}

\section{Assistência de enfermagem humanizada na Unidade de Terapia Intensiva: Um estudo bibliográfico}

\section{Karine Garcez Mc Comb}

Francimeire Gomes Pinheiro

Resumo: A política da humanização tornou-se, nos últimos anos, temática recorrente em investigações e reflexões na área da saúde, interessando aos diferentes ramos do conhecimento científico. Diante do exposto, o objetivo da pesquisa foi de discorrer sobre Assistência de Enfermagem Humanizada ao paciente na Unidade de Terapia Intensiva. Tratou-se de uma pesquisa do tipo qualitativo, descritivo, bibliográfica tipo documental indireta, realizando uma busca em bibliografias atualizadas e recentes. Com isso, seguese relatando a descrição dos diversos conceitos sobre humanização, relatando a funcionalidade da Unidade de Terapia Intensiva, identificando as causas que comprometem a humanização na assistência de enfermagem neste setor. Concluindo a pesquisa verificando a função do enfermeiro e da equipe de enfermagem na UTI, esclarecendo o atendimento humanizado de enfermagem. A Unidade de Terapia Intensiva é uma área destinada a pacientes que necessitam de atendimento médico e de enfermagem contínuo, devido a complexibilidade de eventos e situações que possam vir a ocorrer e, o tratamento utilizado muitas vezes é considerado agressivo e invasivo, necessitando não somente de equipamentos e tecnologia, mas também de uma equipe de enfermagem qualificada para esse atendimento humanizado. Os meios utilizados pela equipe de enfermagem para se alcançar um bom resultado, como o papel do enfermeiro diante de uma Unidade de Terapia Intensiva e de sua equipe é de grande relevância, visando à diminuição do estresse existente dentro da UTI por parte dos pacientes e de seus familiares, contribuindo para o andamento melhor dos cuidados ao paciente.

Palavras-Chave: Assistência hospitalar, Política de humanização, Equipe de enfermagem. 


\section{INTRODUÇÃO}

O interesse pelo tema abordado surgiu após a observação do grande despreparo de muitos profissionais em como atender os pacientes internados e seus familiares na Unidade de Terapia Intensiva. O Ministério da Saúde, (2000) relata que o grande número de iniciativas de humanização em andamento nos hospitais, das mais simples às mais criativas e complexas, demonstra que há necessidade de mudança na forma de gerir a relação entre usuário e profissional de saúde, a qual vem sendo amplamente reconhecida. Comenta também que no campo das relações humanas que caracterizam qualquer atendimento à saúde, é fundamental agregar à eficiência técnica e científica uma ética que considere e respeite a singularidade das necessidades do usuário e do profissional (RODRIGUES e CALEGARI, 2016).

A política da humanização tornou-se, nos últimos anos, temática recorrente em investigações e reflexões na área da saúde, interessando aos diferentes ramos do conhecimento científico. Vários estudos têm sinalizado a urgente necessidade de gestores e profissionais da saúde se adaptarem e desenvolverem, em seus locais de trabalho, uma assistência de acordo com a preconizada pela PNH (COSTA, BURG, SCHAURICH, 2009).

Para Chernicharo, Silva, Ferreira (2014), a humanização da saúde como subsídio para a melhoria do cuidado deve ser um investimento aplicado na formação críticoreflexiva dos estudantes, com a proposta de desenvolver comportamentos, atitudes humanísticas e habilidades para a atuação diferenciada dos futuros profissionais, os quais poderão concretizar os princípios do SUS ao estabelecerem vínculo e compromisso com o usuário, transformando-o em cogestor no processo de cuidar, resultando na assistência de enfermagem humanizada e resolutiva.

0 estudo justifica-se pelo fato da necessidade da comunidade acadêmica, profissionais da enfermagem e população em geral ter um esclarecimento sobre quais os cuidados devem ser abordados frente ao paciente e sua família, já fragilizados pelo tempo de permanência na UTI. É de suma importância para a pratica aos cuidados de enfermagem voltado para esses pacientes que necessitam de cuidado pleno para sua recuperação.

Diante do exposto, o objetivo da pesquisa foi de discorrer sobre Assistência de Enfermagem Humanizada ao paciente na Unidade de Terapia Intensiva

\section{REFERENCIAL TEÓRICO}

\subsection{CONCEITO E TEORIAS DE HUMANIZAÇÃO}

Humanizar é tornar humano. 0 que é humano é estudado por humanistas e humanismo é a palavra que podemos aplicar a quase todas as ideologias modernas e contemporâneas. O humanismo antigo grego e romano exaltava no homem, sobretudo valores de beleza, forca, harmonia, heroísmo (RODRIGUES e CALEGARI, 2016).

Segundo o Ministério da Saúde, (2004); Salicio e Gaiva, (2006) humanizar é passar do cuidado técnico-científico para o acolhimento, transformar a prática de saúde em mais bela, visando à assistência de qualidade vinculada aos avanços tecnológicos.

O humanismo cristão realça o valor do homem como pessoa, isto é como princípio 
autônomo e individual da consciência e responsabilidade, aberto a plenitude do ser e orientado para Deus Não deixa de ser interessante e necessário refletirmos que, apesar de tantas discussões e posições teóricas sobre humanismo, ainda hoje é impressionante a quase universal, constante e flagrante violação dos direitos do homem (CARVALHO, 2000; COSTA, BURG, SCHAURICH, 2009).

\subsection{HUMANIZAÇÃO}

Conforme Knobel (2006) e Lino (2004), humanizar é cuidar do paciente como um todo, englobando o contexto familiar e social, incorporando e respeitando os seus valores, esperanças, aspectos culturais e as preocupações com cada um. Humanizar é também, garantir a qualidade da comunicação entre paciente, família e equipe. Significa ter uma escuta ativa para com o outro, compreende-lo na sua singularidade e nas suas necessidades para que ele se sinta reconhecido e considerado. Não é uma técnica ou artifício, é um processo vivencial que permeia toda a atividade das pessoas que assistem o paciente, procurando realizar e oferecer o tratamento que ele merece como pessoa humana, dentro das circunstâncias peculiares que se encontra em todos os momentos no hospital

Para Silva et al., (2008) a humanização representa um conjunto de iniciativas que visa à produção de cuidados em saúde, capaz de conciliar a melhor tecnologia disponível com promoção de acolhimento, respeito ético e cultural ao paciente, espaços de trabalho favoráveis ao bom exercício técnico e a satisfação dos profissionais de saúde e usuários.

Para Baraúna (2000) humanizar é acolher esta necessidade de resgate e articulação de aspectos indissociáveis: o sentimento e o conhecimento. Mais do que isso, humanizar é adotar uma prática na qual o enfermeiro, o profissional que cuida da saúde do próximo, encontre a possibilidade de assumir uma posição ética de respeito ao outro, de acolhimento do desconhecido, do imprevisível, do incontrolável, do diferente e singular, reconhecendo os seus limites. A possuir uma pré-disposição para a abertura e o respeito ao próximo como um ser independente e digno.

\section{MATERIAL E MÉTODOS}

Foi realizado um levantamento bibliográfico na literatura, com coleta em artigos científicos, monografias, dissertações, revistas científicas, anais de congressos nacionais e internacionais, além de sites de órgãos oficiais como o Ministério da Saúde Para as buscas foram realizadas pesquisas nas bases de dados PubMed (Public Medline), SciELO (Scientific Electronic Library Online) e LILACS (Literatura Latino-americana em Ciências e Saúde) com ênfase nos últimos dez anos de publicação e os descritores utilizados para a coleta dos dados foram: humanização hospitalar, equipe hospitalar, Unidade de Terapia Intensiva.

\section{RESULTADOS e DISCUSSÕES}

\subsection{FUNÇÃO DA EQUIPE DE ENFERMAGEM NA UNIDADE DE TERAPIA INTENSIVA}

0 objetivo final do trabalho da enfermagem é o cuidado e esta deve ter consciência de que a máquina jamais substituirá a essência humana. Quando o profissional se envolve apenas com a técnica, se perde em relação às características 
humanas baseadas na afetividade, no conhecimento de valores, habilidades e atitudes que potencializam a melhora do paciente contribuindo para uma condição humana no processo de viver e morrer. 0 enfermeiro deve reconhecer que sua presença para o paciente é tão importante quanto as técnicas necessárias para sua recuperação (CAETANO et al., 2007).

0 enfermeiro na unidade de terapia intensiva coordena, orienta e supervisiona o pessoal de enfermagem, outros funcionários e o ambiente. 0 enfermeiro é o detentor do saber e controlador do processo de trabalho de sua área de responsabilidade e os outros membros são os executores de tarefas, realizando assim procedimentos de maior complexidade, assumindo e cuidando daqueles neonatos em estado clínico mais grave. No entanto, em alguns momentos, também ocupa-se de atividades consideradas menos complexas como o banho e o controle dos sinais vitais (CAMELO, 2012; MASSAROLI, MARTINI, MASSAROLI, 2015).

Cabe também ao enfermeiro fazer a mediação e comunicação com outros trabalhos e setores do hospital, transmitir e zelar pelo cumprimento das normas da instituição. Os técnicos de enfermagem executam atividades mais manuais; no entanto, em virtude do número pequeno de enfermeiros, os técnicos foram treinados para ajudar em atividades que são privativas do enfermeiro, como é o caso da aspiração do tubo orotraqueal e sondagens (PIRES, 2008).

0 autor descreve ainda que maioria das vezes, o enfermeiro assume de forma integral os cuidados do paciente mais grave. A modalidade de cuidados prestados pela enfermagem na unidade é o cuidado integral e inclui o cumprimento da prescrição médica e de enfermagem. Os chamados "cuidados integrais" são uma modalidade de cuidados em que os trabalhadores da enfermagem ficam responsáveis pelo atendimento integral ao paciente em seu turno de trabalho. Esse tipo de assistência de uma certa maneira rompe com a divisão por tarefas, pois possibilita uma visão mais global das necessidades de cada paciente, além de tornar o trabalho mais criativo.

Para organizar e definir as ações da enfermagem na UTI está implantada uma metodologia assistencial compartilhada pela categoria, ou seja, os enfermeiros utilizam o processo de enfermagem para sistematizar a assistência aos pacientes. 0 processo de enfermagem é constituído de cinco fases que podem variar de acordo com o referencial teórico adotado, são elas: o levantamento de dados, a identificação de problemas, o planejamento, a implementação e a avaliação (NASCIMENTO; TRENTINE, 2004).

\subsection{FUNCIONALIDADE DA UNIDADE DE TERAPIA INTENSIVA}

O cuidar humanizado está inteiramente ligado com o profissional que o executa: seu estado psicológico, físico e mental; com suas experiências anteriores, o cansaço físico pode ser um fator desfavorável à prática do cuidado humanizado. 0 número de profissionais deve ser equivalente ao número preconizado pelo Conselho Regional de Enfermagem para que o cuidado seja adequado, de forma que o profissional tenha condições de ouvir o cliente/paciente, dando atenção às suas reivindicações em relação às coisas simples do seu dia-a-dia (COREN-SP, 2002).

Na UTI adulto todas as vivências são bem parecidas, porém os profissionais de enfermagem, por vários fatores, trabalham com mecanismos nos quais alguns valores e direitos dos pacientes/clientes são negligenciados, direitos estes que na maioria das 
vezes os pacientes/clientes desconhecem; ocorrendo assim a desumanização na assistência de enfermagem, estando muitas vezes ligada a falta de estímulo dos profissionais (HAYASHI; GISI; 2000).

\subsection{ASSISTÊNCIA DE ENFERMAGEM NA UNIDADE DE TERAPIA INTENSIVA}

Segundo a Teoria de Horta (1979), a enfermagem é uma ciência e arte de assistir o ser humano no atendimento de suas necessidades básicas, tornando-o independente desta assistência quando possível (através do ensino do auto cuidado), recuperando, mantendo e promovendo a saúde em colaboração com outros profissionais.

Em algumas UTI os enfermeiros só executam prescrições médicas, não opinam na forma de assistência, predominando a visão cartesiana; a visão holística quase não tem valor e os trabalhadores veem-se como meros executores. Neste contexto, sempre o outro tem a responsabilidade, o médico, como se este tivesse total conhecimento científico de todas as formas de assistência. 0 enfermeiro é aquele que passa mais tempo ao lado destes pacientes/clientes, sendo ele o mais qualificado para tomar as decisões acerca de quais os cuidados são mais adequados a estes pacientes/clientes, sendo também necessário a integração entre os auxiliares e técnicos e o enfermeiro, pois trabalham em prol da qualidade da assistência humanizada (MARTINS; FARIA, 2000).

0 cuidado de enfermagem prestado nas unidades de terapia intensiva, de certa forma, é paradoxal. Em algumas situações, é preciso provocar dor, para que se possa recuperar e manter a vida. Em outras, não se pode falar, apenas cuidar de uma pessoa que não dá sinais de estar sendo percebida como pessoa. 0 cuidado, num caso desses, parece não implicar uma relação de troca, devido à imobilidade ou falta de diálogo e interação com o outro. Sendo assim, é possível pensar que exista, na profissão de enfermagem, uma robotização/mecanização das ações e práticas de cuidado (SOUZA, 2000).

Relembra Souza (2004) a responsabilidade que envolve toda a equipe de saúde, pois está também precisa estar em boas condições emocionais para trabalhar com os pacientes, seus familiares e comunidades. A conquista de um "ser saudável", deve ser buscada não só aos clientes, mas a todos os profissionais que atuam em UTI.

0 profissional de UTI precisa estar atento as necessidades fisiológicas básicas, que, às vezes pode achar ter cumprido o seu dever com o paciente quando ou não o tem lesado ou não o tem desrespeitado conscientemente. Resgatar a humanidade neste setor talvez seja voltar a refletir, cada vez mais conscientemente, sobre o que e ser humano. A UTI precisa e deve utilizar-se dos recursos tecnológicos cada vez mais avançados, porém, os profissionais que ali trabalham não deve esquecer que jamais a máquina substituirá a essência humana (SOUZA, 2004; GRANDE et al., 2012).

\subsection{ATENDIMENTO HUMANIZADO DE ENFERMAGEM NA UNIDADE DE TERAPIA INTENSIVA}

Knobel (2006) conceitua que humanizar a UTI significa cuidar do paciente como um todo, englobando o contexto familiar e social, devendo esta prática incorporar os valores, as esperanças, os aspectos culturais e as preocupações de cada um. Cada indivíduo é único e tem necessidades, valores e crenças próprias. 
O mesmo autor descreve que a hospitalização em UTI pode acarretar alterações psicológicas e sociais não só ao paciente, mas também a sua família, assim as Unidades de Terapia Intensiva passaram a focar não a penas a recuperação do paciente, mas também seu bem-estar e suas características e necessidades individuais. Os profissionais devem ser preparados para atuar junto ao paciente e à família no sentido de minimizar os efeitos e transtornos decorrentes da hospitalização na UTI.

A humanização na Unidade de Terapia Intensiva, onde se presta cuidados a pacientes críticos, os profissionais de saúde especialmente os enfermeiros, necessitam utilizar a tecnologia aliada a empatia, a experiência e a compreensão do cuidado prestado fundamentado no relacionamento interpessoal terapêutico, a fim de promover um cuidado seguro, responsável e ético em uma realidade vulnerável e frágil. Cuidar em Unidades Criticas é ato de amor, o qual está vinculado: a motivação, comprometimento, postura ética e moral, características pessoais, familiares e sociais (SILVA, 2000).

A relação profissional-paciente/familiares é muito importante no momento diagnóstico e ao longo do tratamento. Esta relação deve ser caracterizada pelo estabelecimento de vínculo, o qual é definido por Ferreira (1986) como: tudo que ata, liga, ligação moral; relação, nexo; prender, unir. No âmbito da saúde, criar vínculos requer o estabelecimento de relações próximas e claras, de forma que o sofrimento do outro seja sensibilizador. Visa estabelecer processo que busca a autonomia do paciente, bem como o compartilhamento da responsabilidade por sua vida ou morte (RIZZOTTO, 2002).

Souza (2000) salienta que é importante que a equipe esteja atenta ao trabalho interativo, colaborando para o saber interdisciplinar e facilitando o processo de comunicação. Devemos ter em mente que trabalhar numa UTI e tentar mantê-la mais humanizada, é aceitar que o estresse existe que o ambiente é propício à ansiedade e emersão de conflitos, onde o enfermeiro deve reconhecer que sua presença é tão importante quanto os procedimentos técnicos. Humanizar é tornar humano, o que é humano, é estudado por humanistas e humanismo é uma palavra que podemos aplicar a quase todas as ideologias e não deixa de ser interessante e necessário refletirmos, que apesar de tantas discussões e posições teóricas sobre humanismo, ainda hoje é impressionante a quase universal, constante e flagrante violação dos direitos do homem e de sua dignidade em nossos dias

\subsection{HUMANIZAÇÃO COM O PACIENTE E COM A FAMÍLIA}

Quando o enfermeiro opta pelo cuidado e não pela cura, ou seja, quando ele não se torna escravo da tecnologia, mas aprende a usar a tecnologia a favor da harmonização do paciente do seu bem estar físico, fica mais claro sobre alguns aspectos. Ele passa a valorizar a técnica por ela ser uma aliada na tentativa de preservar a vida e o bem estar e o conforto do paciente. Não coloca em segundo plano esses detalhes de humanização, justamente o contrário acontece, porque o respeito ao ser humano e tão grande, desempenhar bem a técnica se torna fundamental. Mas também não ignora que o benefício para o paciente pode ser tido através de dados biológicos e através de dados mais subjetivos como ele referir estar melhor, mais forte, mais tranquilo (MORAES, 2004).

A dor, o fato de não conseguir dormir, ter tubos no nariz ou na boca, não ter controle de si mesmo, são estressores frequentemente apontados pelos pacientes de UTI 
relacionados diretamente com o conforto físico e a sensação de bem estar, e que, portanto, requerem identificação e intervenções pela equipe de enfermagem. 0 controle da dor, reconhecidamente, o principal fator estressor apontado pela maioria dos pacientes, deve ser instituído de maneira eficiente (KNOBEL, 2006).

O paciente na UTI apresenta suas necessidades básicas alteradas, é despojado de sua privacidade e vivencia situações não planejadas as quais não podem controlar. Essa situação gera desconforto, que pode configurar-se em uma situação de estresse. A humanização e o cuidado ao paciente de terapia intensiva implica reconhecer e atuar na minimização desses fatores estressores. É preciso identificar os estressores percebidos pelo paciente, que sejam possíveis de intervenção pela equipe, proporcionando melhor condição de internação (KNOBEL, 2006).

O desconforto do paciente com o uso de tubos e sondas no nariz ou boca, pode ser minimizado por meio de informação previa ao paciente quando possível. No momento e que a possibilidade de cura já não se configura no tratamento do paciente, a humanização é muito importante. Do Latim paliare, cuidados paliativos significa aliviar e implica uma assistência ativa e integral aos pacientes cujas doenças não respondem mais ao tratamento curativo. Seu principal objetivo é a garantia de melhor qualidade de vida tanto para o paciente como para os seus familiares, garantindo a assistência física, emocional e espiritual (KNOBEL, 2006).

Knobel (2006) relata que inicialmente, a assistência de enfermagem na UTI era focada exclusivamente ao paciente, em sua evolução, observação e monitoração de complicações, e pouca ênfase era dada para os problemas sociais e familiares. Nos últimos dez anos, alguns estudos começaram a examinar os fatores nos pacientes graves, deixando ainda os assuntos relacionados a família em segundo plano. A assistência humanizada a família implica compreender o processo vivenciado quando um dos seus membros é internado no CTI, para que assim a e1quipe interdisciplinar tenha condições de reconhecer a condição destes familiares e suas necessidades.

Orlando (2002) e Silva (2004) concordam que durante esta última década, tem-se falado sobre a humanização das Unidades de Terapia Intensiva, principalmente por esta ser considerada ambiente de elevada tensão, com incertezas no tocante à sobrevivência, o que produz ansiedade, facilmente traduzida em estresse para o paciente e seus familiares.

0 enfermeiro tem o compromisso e a obrigação de incluir as famílias nos cuidados de saúde. 0 significado que a família dá para o bem-estar e a saúde de seus membros, bem como à influência sobre a doença, obriga este profissional a considerar a assist6encia centrada na família como parte integrante da família de enfermagem (DAMAS et al, 2004).

Knobel (2006) esclarece que desta forma, o cuidado holístico deve incluir também o cuidado com a família, resgatando o conceito de bem-estar biossociopsicoespiritual, o que aumentam o campo de atuação do enfermeiro intensivista. Os familiares hoje participam do cuidado, opinam, ajudam a decidir, e isso exige preparo. Surge assim uma nova atribuição para o enfermeiro intensivista, uma vez que a psicologia hospitalar ainda não atinge todas as instituições.

0 relacionamento entre o profissional de enfermagem e a família deve ser um encontro de subjetividade do qual emergem novas compreensões e interpretações, contribuindo para o sucesso do tratamento e a superação da crise ocorrida durante a 
hospitalização. Nesse sentido é importante estar atento ao fato de que as propostas de humanização em saúde também envolvem o processo de formação do profissional, ainda centrado no aprendizado técnico e individualizado, com tentativas muitas vezes isoladas de exercício da crítica, criatividade e sensibilidade levando a cristalização dos sentimentos do profissional na construção de uma relação de ajuda eficiente aos usuários dos serviços de saúde bem como seus familiares (FERNANDES; ANDRAUS; MUNARI; 2006).

\subsection{TERAPIA HUMANIZADAS}

A musicoterapia e o uso terapêutico de determinados tipos de músicas que podem afetar o fisiológico, o emocional e o comportamento de quem a escuta. Já existem pesquisas demonstrando seu uso para diminuição do estresse em pacientes na unidade de terapia intensiva, assim como diminuição do ritmo cardíaco e aumento da temperatura corporal (CINTRA, 2003).

Cintra (2003) ainda destaca que sabemos que não e sempre que podemos dar o melhor atendimento possível. Uma boa estruturação de UTI envolve pessoal em número suficiente e especialmente treinado para fornecer assistência especifica e observação continuada.

\section{CONCLUSÃO}

Com a finalização da pesquisa e o término do trabalho concluiu-se que é necessário um preparo mais científico dos profissionais da área de saúde, mais especificamente da equipe de enfermagem, voltadas não só para o aspecto teórico e técnico, como também numa perspectiva mais humanitária. Cabe a essa classe uma atitude individual para resgatar essa humanização em relação a um sistema tecnológico dominante, que vise o bem-estar do paciente em estado mais grave, que permanece internado na Unidade de Terapia Intensiva, seja por curto ou longo prazo.

A humanização se faz necessária para um cuidado efetivo, considerando observar e orientar a família durante todo o período de hospitalização. A interação entre enfermagem/paciente/família deve ser estabelecida através do diálogo e da busca dos significados que as experiências de doença geram em cada pessoa. A convivência da família próxima ao paciente é fundamental para a sua recuperação e mais eficaz do que qualquer outra relação e o enfermeiro atuante neste setor deve sempre ter essa base em seu conhecimento.

\section{REFERÊNCIAS}

BRASIL. Ministério da Saúde, Secretaria-Executiva. Núcleo Técnico da Política Nacional de Humanização. Humaniza SUS Política nacional de Humanização (versão preliminar). Brasília, 2000.

CAETANO, Joselany Áfio; SOARES, Enedina; ANDRADE, Luciene Miranda; PONTE, Roberta Maria da. Cuidado humanizado em terapia intensiva: um estudo reflexivo. Escola Anna Nery Revista de Enfermagem; 2007.

CAMELO, Silvia Helena Henriques. Competência profissional do enfermeiro para atuar 
em Unidades de Terapia Intensiva: uma revisão integrativa. Rev. Latino-Am. Enfermagem, Ribeirão Preto, v. 20, n. 1, p. 192-200, Feb. 2012.

CARVALHO, M. C. B.(org). A família contemporânea em debate. São Paulo: Educ/Cortez, 2000. 122p.

CHERNICHARO IM, SILVA FD, FERREIRA MA. Caracterização do termo humanização na assistência por profissionais de enfermagem. Esc Anna Nery Rev Enferm. 2014[acesso em 01.02.2021];18(1):156-62.

COSTA, Silvio Cruz; FIGUEIREDO, Maria Renita Burg; SCHAURICH, Diego. Humanização em Unidade de Terapia Intensiva Adulto (UTI): compreensões da equipe de enfermagem. Interface (Botucatu), Botucatu, v. 13, supl. 1, p. 571580, 2009. Available from <http://www.scielo.br/scielo.php?script=sci_arttext\&pid=S1414$32832009000500009 \& \operatorname{lng}=e n \& n r m=i s o>$. Acesso em 13 Mar. 2021.

COREN/SP. A arte como ferramenta na humanização hospitalar. Rev. Coren-SP, n. 42, p.7-11, set. 2002

DAMAS, K.C.A., MJUNARI, D.B., SIQUEIRA, K.M., Cuidando do cuidador: reflexões sobre o aprendizado dessa habilidade. Disponível em: <http://www.fen.ufg.br>. Acesso em: 18 de agosto de 2010.

FERNANDES, C. N. S.; ANDRAUS, L. M. S.; MUNARI, D. B. 0 aprendizado do cuidar da família da criança hospitalizada por meio de atividades grupais. Revista Eletrônica de Enfermagem. [serial on line], 2006 [cited 2006, jan. 11], 8 (01), p. 108-118. Availablem from:http://www.fen.ufg.br/revista/revista8 1/original 14.htm.

GRANDE CENEDÉSI, MICHELI; BERNARDINO, ELIZABETH; RIBEIRO LACERDA, MARIA; DALLAIRE, CLÉMENCE; LIMA, KAOANA. Funções desempenhadas pelo enfermeiro em unidade de terapia intensiva. Revista da Rede de Enfermagem do Nordeste, vol. 13, núm. 1, pp. 92-102. 2012.

HAYASHI, A.A.M; GISI, M.L. O cuidado de enfermagem no CTI: da ação-refleção à conscientização.Texto Contexto Enfermagem. Florianópolis, v.9, n.9,p.824-837, mai./ago, 2000.

KNOBEL, Elias. Terapia Intensiva: enfermagem. São Paulo: Ed. Atheneu, 2006

LINO, M.M. Qualidade de vida e satisfação de enfermeiras de unidade de terapia intensiva. São Paulo, 2004.

MARTINS, J. de. J; FARIA, E. M. A reorganização do trabalho da enfermagem em UTI. Rev. Texto e Contexto Enfermagem, Florianópolis, v. 9, n. 2, p. 388-401, 2000.

MASSAROLI, Rodrigo et al . Trabalho de enfermagem em unidade de terapia intensiva e sua interface com a sistematização da assistência. Esc. Anna Nery, Rio de Janeiro , v. 19 , n. 2, p. 252-258, 2015 .

Ministério da Saúde (BR). Núcleo Técnico da Política Nacional de Humanização. Política 
Nacional de Humanização: a humanização como eixo norteador das práticas de atenção e gestão em todas as instâncias do SUS. Brasília: Ministério da Saúde; 2004.

NASCIMENTO, E.R.P., TRENTINI, M. O cuidado de enfermagem na UTI: Teoria Humanística de Paterson e Zderad - ver. Latino Americana de Enfermagem, 2004.

PIRES, D. Reestruturação produtiva e trabalho em saúde no Brasil. São Paulo (SP): Annablume; 2008.

RIZZOTTO, M. L. F. As Políticas de Saúde e a Humanização da Assistência. Revista Brasileira de Enfermagem, v. 55, n. 2, p. 196-199, Mar-Abr. 2002.

RODRIGUES, A. C.; CALEGARI, T. Humanização da assistência na unidade de terapia intensiva pediátrica: perspectiva da equipe de enfermagem. REME - Rev Min Enferm. 20:933.2016.

SALICIO DMB, GAIVA MAM. O significado de humanização da assistência para enfermeiros que atuam em UTI. Rev Eletrônica Enferm. 2006[acesso em 20.02.2021];8(3):370-6. Disponível em: http://www.fen.ufg.br/revista/revista8_3/ v8n3a08.htm

SOUZA, LNA. A interface da comunicação entre enfermagem e as(os) clientes em uma unidade de terapia intensiva [dissertação]. Florianópolis: Departamento de Enfermagem, Universidade Federal de Santa Catarina; 2000.

SILVA, V. E. F. O desgaste do trabalhador de enfermagem: relação trabalho de enfermagem e saúde de trabalhador [tese]. São Paulo: USP/ Escola de Enfermagem, 2000.

SILVA, Roberto Carlos Lyra da; PORTO, Isaura Setenta; FIGUEIREDO, Nébia Maria Almeida de. Reflexões acerca da assistência de enfermagem e o discurso de humanização em terapia intensiva. Escola Anna Nery Revista de Enfermagem; 2008. 


\section{Capítulo 7}

\section{Atuação multidisciplinar no aconselhamento genético em predisposição hereditária ao câncer}

\section{Thiago de Jesus Bacha}

Sabrina da Fonseca Meireles

Fernanda Teresa de Lima

Resumo: A avaliação e aconselhamento sobre o risco de câncer é um serviço consultivo que inclui análise clínica, diagnóstico, identificação de riscos, teste genético quando apropriado e recomendações de gerenciamento de risco apresentadas no contexto de uma ou mais sessões de aconselhamento genético. 0 aconselhamento genético pré-teste é uma parte importante do processo de avaliação de risco e ajuda os pacientes a entenderem suas opções de testes genéticos e resultados potenciais. 0 aconselhamento genético pós-teste ajuda os pacientes a entender os resultados dos exames, incluindo as implicações médicas para eles e seus familiares. Desta forma, o processo de aconselhamento genético pode incluir a participação multiprofissional (psicólogos, enfermeiros, médicos, dentre outros). Nesse sentido, o presente trabalho discorre sobre a atuação multiprofissional no aconselhamento genético ao câncer. Para atingir ao objetivo proposto, realizou-se uma revisão de literatura nas principais bases de dados, com publicações dos anos de 2009 a 2019. Verificou-se que o aconselhamento sobre avaliação de risco de câncer emergiu como uma prática especializada que requer conhecimento de genética, oncologia e habilidades de aconselhamento individual e familiar que podem ser fornecidas por profissionais de saúde com esse treinamento interdisciplinar.

Palavras-chave: Biologia molecular, Diagnóstico, Doenças hereditárias, Genética clínica, Oncogenética. 


\section{INTRODUCĈ̃O}

A genética médica ou genética clínica é a especialidade que lida com o diagnóstico, tratamento e controle dos distúrbios genéticos e hereditários. Esse ramo da medicina era considerado altamente especializado, de pouca importância para o público em geral (MOREIRA e MELO, 2012). No entanto, esses conceitos mudaram, em grande parte, com o reconhecimento de que muitos distúrbios comuns podem ter componentes genéticos, graças ao desenvolvimento de testes diagnósticos baseados em biologia molecular, tornando necessário o conhecimento básico de genética para qualquer profissional de saúde (MOREIRA e MELO, 2012).

No Brasil, as estimativas de novos casos de câncer no biênio 2018-2019 foram 600 mil para cada ano. Com exceção do câncer de pele não melanoma, com cerca de 170 mil casos novos (INCA, 2018). Projetou-se ainda, a ocorrência de 640 mil casos novos de câncer, segundo o cálculo global corrigido para o sub-registro (conjunto de informações não registradas no próprio ano). Esses índices reproduzem o quadro de um país que possui os cânceres de pulmão, próstata, cólon, mama feminina e reto entre os mais incidentes, no entanto, ainda revela altas taxas para os cânceres estômago, do colo do útero e esôfago (INCA, 2018).

A maioria dos cânceres resulta de interações complexas entre a composição genética do indivíduo e o meio ambiente, uma pequena porcentagem de cânceres está relacionada principalmente a alterações hereditárias que conferem uma alta predisposição à doença (FETT-CONTE et al., 2013). Indivíduos com formas hereditárias de câncer desenvolvem um ou mais tumores em idade precoce, e podem transmitir essa predisposição para seus descendentes (SILVA et al., 2013). Hoje, estima-se que pelo menos $5-10 \%$ de todos os tumores estão associados a componentes hereditários, e mais de 50 síndromes distintas foram descritas como conferindo predisposição ao câncer (SILVA et al., 2013).

Desde a suspeita clínica de predisposição hereditária ao câncer, até a identificação de um gene alterado, existem muitas maneiras disponíveis para um melhor atendimento destas famílias, entre eles, diagnósticos moleculares e testes preditivos estão disponíveis, os quais são importantes na assistência de famílias em risco. Esses testes também são considerados na elaboração de protocolos para rastreamento, diagnóstico precoce e prevenção do câncer nesses casos (MOREIRA-NUNES et al., 2014). Atualmente tem aumentado a procura por consultas médicas e internações por doenças genéticas, especialmente em grandes centros e hospitais de referência no Brasil (FLÓRIA - SANTOS et al., 2013).

O diagnóstico e aconselhamento genético para indivíduos e famílias com doenças hereditárias envolve, na maioria dos casos, exames laboratoriais nas áreas de citogenética e genética molecular (FLÓRIA -SANTOS et al., 2013). Os serviços de saúde públicos e privados especializados em genética nem sempre dispõem de tecnologia, equipes treinadas e testes genéticos necessários para o diagnóstico (LAJUS et al., 2015). Essas tecnologias de diagnóstico molecular só foram adicionadas à lista de procedimentos do Sistema Único de Saúde (SUS) em 2014, contemplando apenas doenças raras (ABACAN et al., 2018), e a triagem molecular para câncer hereditário, só foi incluída como um procedimento de cobertura compulsória da Agência Nacional de Saúde (ANS) em 2012.

Estimar os custos dessas novas tecnologias ajudaria no desenvolvimento de melhores estratégias para permitir maior acesso e equidade de atendimento (LAJUS et 
al., 2015). Considerando a limitação de exames genéticos para a população como um todo e as lacunas no conhecimento sobre o tipo de paciente e famílias que buscam aconselhamento genético de câncer no Brasil ou se os serviços existentes estão de fato atingindo indivíduos com alto risco de síndromes de predisposição ao câncer, propôs-se a realização deste estudo, com objetivo de descrever a atuação multidisciplinar no aconselhamento genético ao câncer, a partir de dados acurados na literatura científica.

\section{REFERENCIAL TEÓRICO}

\subsection{ASPECTOS PRINCIPAIS DA GENÉTICA E HEREDITARIEDADE}

0 termo "genético" não significa necessariamente "hereditário". 0 primeiro termo implica simplesmente que o material genético, em um nível cromossômico ou gênico, contém uma ou mais mutações que são a causa do distúrbio (BRASIL, 2015). Uma vez que uma mutação esteja presente nas células germinativas de um paciente pode, é claro, ser transmitida e, assim, tornar-se um distúrbio hereditário (BRASIL, 2015), que podem ser de quatro tipos, segundo Horovitz et al. (2013), a saber:

1- Distúrbios cromossômicos: afetam cerca de 1/200 nascidos vivos (e cerca de $1 / 500$ adultos). Anomalias no número de cromossomos raramente são herdadas, embora indivíduos afetados que se reproduzam possam transmitir o cromossomo extra para seus filhos. Anormalidades estruturais, como translocações nas quais dois cromossomos trocam segmentos, podem causar pouco ou nenhum efeito nos portadores, mas predispõem a problemas reprodutivos como aborto e infertilidade (HOROVITZ et al., 2013);

2- Herança Monogênica (Mendeliana): é o resultado de mutações em genes individuais, em loci específicos de genes. Esse tipo de herança é causado por alterações ou mutações que ocorrem na sequência de DNA de um único gene. Existem mais de 6.000 desordens conhecidas de um único gene, que ocorrem em cerca de 1 em cada 200 nascimentos. Alguns exemplos são fibrose cística, anemia falciforme, síndrome de Marfan, doença de Huntington e hemocromatose. Os distúrbios de um único gene são herdados em padrões reconhecíveis: autossômica dominante, autossômica recessiva e ligada ao cromossomo X (KLAUTAU-GUIMARÃES et al., 2014);

3- Poligênica ou multifatorial: embora essa causa não seja "tão genética" quanto os distúrbios monogênicos e cromossômicos, a maioria das malformações e dos distúrbios familiares comuns tem esse tipo de causa. Esse tipo de herança é causado por uma combinação de fatores ambientais e mutações em múltiplos genes. Algumas doenças crônicas comuns são distúrbios multifatoriais. Exemplos incluem doenças cardíacas, pressão alta, doença de Alzheimer, artrite, diabetes, câncer e obesidade (HOROVITZ et al., 2013). A herança multifatorial também está associada a traços hereditários, como padrões de impressões digitais, altura, cor dos olhos e cor da pele (HOROVITZ et al., 2013; BRASIL, 2015); 
4- Distúrbios mitocondriais: resulta de mutações no genoma mitocondrial. Cada célula contém centenas de mitocôndrias, cada uma contendo um ou vários cromossomos circulares. Esses cromossomos podem ser deletados ou sofrer outros tipos de mutações que interferem em uma série de funções celulares; os sintomas dependem dos tecidos envolvidos e da proporção de mitocôndrias mutantes, mas envolvem primeiro o sistema nervoso central e o músculo, devido às suas grandes demandas energéticas (BRASIL, 2015). A incidência de mutações mitocondriais em doenças humanas ainda é desconhecida. Em muitos casos, a mutação é nova em um indivíduo afetado, mas a transmissão hereditária é puramente materna, uma vez que as mitocôndrias de um óvulo fertilizado se originam apenas da célula germinativa materna (HOROVITZ et al., 2013).

\subsection{CARACTERÍSTICAS DO ACONSELHAMENTO GENÉTICO}

Sheldon Clark Reed cunhou o termo aconselhamento genético em 1947 e publicou o livro "Counseling in Medical Genetics" em 1955. A maioria das clínicas de aconselhamento genético inicialmente, era dirigida por cientistas não médicos ou por aqueles que não eram clínicos experientes. Com o aumento do conhecimento de desordens genéticas e o surgimento da genética médica como uma especialidade distinta na década de 1960, o aconselhamento genético tornou-se progressivamente medicalizado, representando um dos principais componentes da genética clínica (KLAUTAU-GUIMARÃES et al., 2014).

0 aconselhamento genético pode ser descrito como o processo pelo qual os indivíduos afetados ou com suspeita de alterações genéticas, são avaliados, e caso comprove alguma alteração, são informados sobre a natureza de seu problema, das consequências do distúrbio, da probabilidade de herança ou transmissão a seus filhos e dos potenciais meios de tratar ou de evitar complicações do distúrbio em questão (ASHTON-PROLLA e SEUANEZ, 2016). Com o reconhecimento de que uma gama cada vez maior de doenças pode ser advinda de alterações genéticas, o aconselhamento tornou-se crescente em centros especializados (GUEDES e DINIZ, 2009).

Diante da necessidade de aumentar a atenção em Genética Médica, instituiu-se em janeiro de 2009, pelo Ministério da Saúde do Brasil, no âmbito do Sistema Único de Saúde (SUS), a Política Nacional de Atenção Integral em Genética Clínica (PNAIGC), cujo objetivo principal é organizar uma linha de cuidados integrais que compreenda promoção, prevenção, tratamento e reabilitação de pacientes com doenças genéticas, perpassando todos os níveis de atenção à saúde e com atuação profissional interdisciplinar (BRASIL, 2009). Além disto, a PNAIGC também objetiva a identificação dos determinantes e condicionantes dos principais problemas de saúde relacionados às doenças genéticas, de forma a fornecer subsídios para a elaboração de ações e políticas públicas no setor, qualificar a assistência e promover educação permanente dos profissionais de saúde em conformidade com os princípios da integralidade e da Política Nacional de Humanização do SUS (BRASIL, 2009).

\section{MATERIAL E MÉTODOS}

A pesquisa delineou-se em uma revisão de literatura em artigos e revistas que apresentam fatores de impacto significativo, periódicos especializados nacionais e 
internacionais nas bases de dados online Scientific Electronic Library Online (SCIELO), Public Medline or Publisher Medline (PUBMED) e Literatura Latino- Americana em Ciências da Saúde (LILACS), com pesquisa realizada nos meses de janeiro a março de 2019.

Como critérios para inclusão foram utilizados os descritores "Aconselhamento genético", "Oncologia", "Multiprofissionais" bem como publicações do período de 2009 a 2019, sem restrição a idiomas. Como critérios de exclusão foram definidos: Publicações não decorrentes de pesquisa científica como editoriais, comentários, relato de experiências, artigos não relacionados com a temática.

\section{RESULTADOS E DISCUSSÃO}

Na primeira pesquisa encontrou-se um total de 89 artigos e após a utilização dos critérios de exclusão permaneceram apenas 28 artigos que subsidiaram o presente trabalho. Os artigos foram selecionados primeiramente por título, leitura de seus resumos e, posteriormente, por leitura na íntegra.

\subsection{DA ATUAÇÃO MULTIDISCIPLINAR NO ACONSELHAMENTO GENÉTICO AO DIAGNÓSTICO}

Médicos de diversas especialidades, como médicos de família, pediatras e obstetras, quando estão diante de uma suspeita de doença hereditária, orientam seus pacientes a procurarem um geneticista; no entanto, são poucos os serviços genéticos ofertados em regiões mais afastadas dos centros urbanos (GUEDES e DINIZ, 2009).

Quatro aspectos estão envolvidos no aconselhamento genético, explicitados abaixo:

1- Chegar a um diagnóstico específico: muitas vezes é a parte mais difícil, trabalhosa e demorada do processo, tanto para médicos quanto para a família (que estão compreensivelmente mais preocupados com o cuidado de seu parente afetado do que com o nome específico do seu distúrbio). No entanto, sem um diagnóstico correto, o aconselhamento é, na melhor das hipóteses, incompleto e impreciso (MENDES, 2012);

2- Estimativa de riscos: identificação da possibilidade de desenvolvimento do distúrbio e / ou transmissão aos filhos (MENDES, 2012; HERR et al., 2013);

3- Ajuda prática: isso inclui, por exemplo, recomendar exames especializados ou profissionais de saúde para terapia de fala ou educacional. Muitas vezes implica também a coordenação do pré-natal e outros testes de diagnóstico (HERR et al., 2013);

4- Papel de suporte: este aspecto é tão importante quanto a questão diagnóstica, pois a grande maioria dos distúrbios genéticos não pode ser curada ou mesmo tratada satisfatoriamente (HERR et al., 2013). Embora o conselheiro genético não possa fornecer apoio diário para a família, ele deve ser capaz de orientá-lo 
para os profissionais de saúde que possam melhor atendê-los nessa função (MENDES, 2012). Aceitar e aprender a conviver com um diagnóstico genético é particularmente difícil quando há opções reprodutivas envolvidas, e sentimentos de "culpa" podem afetar várias gerações e causar desentendimentos na família justamente quando a solidariedade é mais necessária (MENDES, 2012).

A disponibilidade de exames diagnósticos (painéis genéticos, testes genéticos de pré-natal, dentre outros) para doenças genéticas segue um padrão de distribuição semelhante ao dos serviços públicos de genética médica no Brasil, com maior concentração nas regiões Sul-Sudeste (BRASIL, 2015). Na Figura 1 estão descritos os dados acerca dos testes para diagnósticos de doenças genéticas atualmente preconizados.

Figura 1: Tipos de testes diagnósticos de doenças genéticas no Brasil.

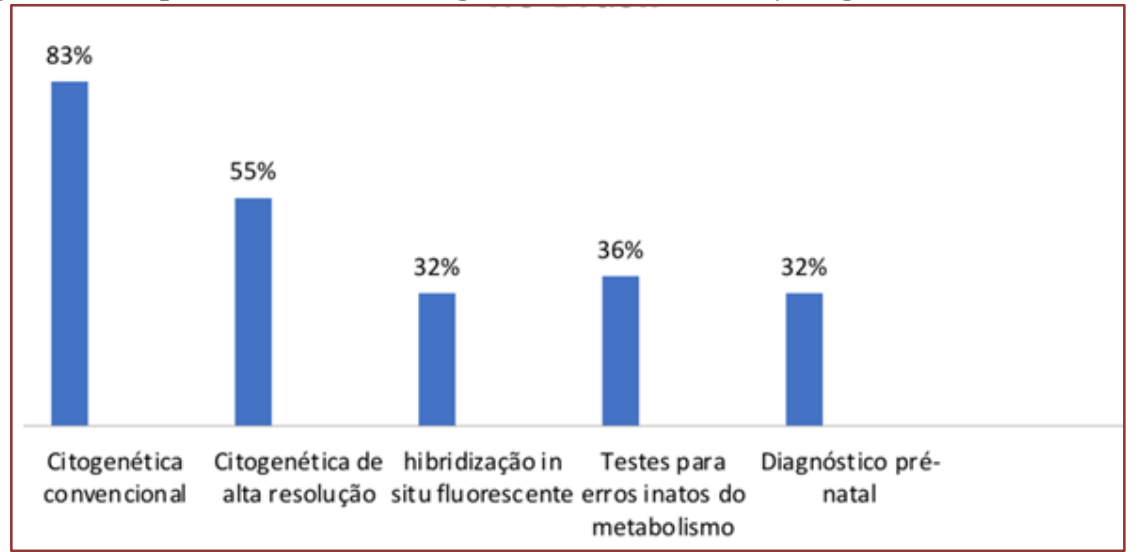

Fonte: Horovitz et al. (2013).

0 uso de técnicas de biologia molecular tem crescido e alguns grupos de pesquisa implementaram o uso de tecnologia de Sequenciamento de Nova Geração (Next Generation Sequencing - NGS), porém a maioria deles os introduziram por meio de financiamentos de projetos de pesquisa. A permanência dessa técnica e seu uso para diagnóstico, no entanto, tem sido dificultada em muitas instituições por falta de financiamento, uma vez que são técnicas onerosas (HOROVITZ et al., 2013). Esse quadro deveria ter mudado após a implementação da política de doenças raras, pois os serviços especializados foram incentivados a prestar atendimento integral, incluindo diagnóstico laboratorial, com a disponibilização de financiamento federal específico (KLAUTAUGUIMARÃES et al., 2014).

No âmbito privado, os testes genéticos têm maior disponibilidade, o que permite celeridade na investigação e acesso a exames complementares, sendo a principal diferença entre atendimento privado e consultas em hospitais públicos. Grande parte de procedimentos de teste estão disponíveis no setor privado, incluindo não apenas o diagnóstico de doenças genéticas de indivíduos afetados, mas também diagnóstico genético pré-implantação, diagnóstico pré-natal, diagnóstico pré-natal não invasivo, triagem neonatal expandida, testes preditivos e farmacogenética (BRASIL, 2015).

O setor privado geralmente faz uso de técnicas mais avançadas, incluindo a recente disponibilidade de exoma - conjunto de éxons que codificam os aminoácidos de cada gene e sequenciamento de genoma, que se tornou disponível em alguns laboratórios privados em algumas das capitais do Brasil. No entanto, apesar da 
disponibilidade desses testes, algumas vezes as amostras são enviadas ao exterior para processamento e as empresas de planos de saúde nem sempre cobrem os custos (BRASIL, 2015).

\subsection{MODELOS DE ACONSELHAMENTO GENÉTICO}

0 modelo tradicional para serviços genéticos de câncer foi estabelecido pela Sociedade Nacional de Conselheiros Genéticos dos Estados Unidos da América. Os elementos essenciais de uma consulta inicial sobre genética do câncer incluem: histórico médico pessoal e familiar, avaliação psicossocial e avaliação de risco. 0 processo tradicional de várias etapas, também conhecido como modelo de três visitas, inclui a avaliação inicial do risco de câncer, a predisposição e a coleta de sangue e a divulgação dos resultados.

Há evidências, no entanto, de que o modelo tradicional de aconselhamento genético do câncer está evoluindo. Mudanças na prática ocorreram para melhor se adaptar às necessidades médicas do paciente. Por exemplo, Wham et al. (2010) pesquisaram práticas de aconselhamento genético de câncer através do Grupo de Interesse Especial de Aconselhamento de Risco Familiar dos Estados Unidos e relataram resultados sobre parâmetros incluindo o número de sessões, o modo de entrega, documentação e divulgação de resultados, conforme demonstra a Figura 2.

Figura 2: Quantificação do número de visitas aos pacientes.

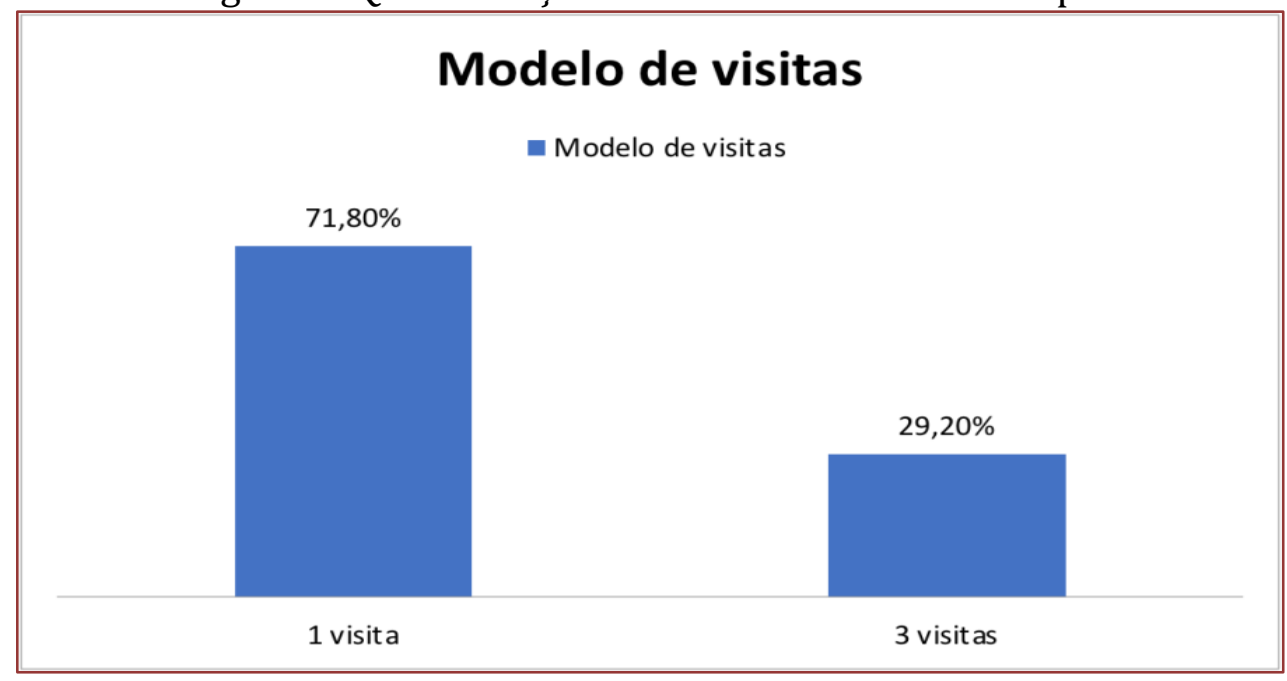

Fonte: Wham et al. (2010).

Os resultados dos estudos de Wham et al. (2010) vão de encontro às diretrizes profissionais de aconselhamento genético, que propõem um modelo de 3 visitas e, constata-se, por meio do gráfico 2, que um índice bem pequeno faz uso de tal modelo, uma vez que os entrevistados verificam a conduta em apenas uma visita, eliminando a segunda visita e realizando a divulgação do resultado por telefone, o que acaba por substituir a terceira visita. Este estudo revelou ainda que 90 (56\%) dos conselheiros genéticos achavam que 30 a 60 minutos eram suficientes para informar o paciente adequadamente, contrapondo aos 90 minutos tradicionais previstos para a sessão inicial (WHAM et al., 2010).

Outro dado importante é que os pacientes chegam à consulta de aconselhamento genético oncológico com um nível de conhecimento mais elevado e maior desejo de 
buscar informações genéticas. Portanto, os conselheiros genéticos podem precisar gastar menos tempo na educação com informações factuais do paciente, o que pode permitir que eles vejam um volume maior de pacientes (COSTA et al., 2013). Portanto, há uma necessidade imediata de aumentar a visibilidade e o acesso a provedores genéticos (os governos ou organizações da sociedade civil) para garantir testes apropriados e conter custos no sistema de saúde atual (COSTA et al., 2013; BRASIL, 2019).

Modelos alternativos de prestação de serviços têm o potencial de aumentar o acesso ao aconselhamento genético oncológico, que é de importância crescente à medida que a informação genômica hereditária é cada vez mais incorporada ao cuidado de indivíduos com câncer e seus familiares em risco (BRASIL, 2013). Aconselhamento por telefone, aconselhamento em grupo e telegenética (fornecido remotamente por videoconferência ao vivo, com acesso visual e por áudio) têm sido bem aceitos pelos pacientes e podem facilitar a comunicação centrada no paciente e a avaliação psicossocial que são a marca do aconselhamento genético do câncer (ABRAMS e GEIER, 2006; BRASIL, 2013). Diante dessas evidências, o aconselhamento genético em predisposição hereditária ao câncer começou a se adaptar às necessidades atuais dos pacientes (MACKAY e TAYLOR, 2006; ZON et al., 2009).

\subsection{EVOLUÇÃO DO ACONSELHAMENTO GENÉTICO NO BRASIL}

A disponibilidade tecnológica fez com que o processo de aconselhamento genético mudasse drasticamente nos últimos 25 anos. Em vez de se basear em achados puramente clínicos, a identidade de muitos distúrbios pode ser comprovada porque sua base gênica ou cromossômica é conhecida. A disponibilidade de um número cada vez maior de exames laboratoriais permite diagnósticos mais precisos e, muitas vezes, permite diagnóstico pré-sintomático ou pré-natal a membros da família (EL RHAZI et al., 2014; HOROVITZ et al., 2013). No entanto, não se deve esquecer que a disponibilidade de tais testes também levanta questões psicológicas e éticas difíceis de resolver (MELO e SEQUEIROS, 2012; MARQUES et al., 2013).

0 treinamento de pessoas competentes para realizar aconselhamento genético foi formalizado em vários países europeus, nos Estados Unidos e no Canadá há alguns anos através de seus respectivos Conselhos de Genética Médica (WHAM et al., 2010). Médicos com formação em genética médica dependem de citogeneticistas e geneticistas moleculares para realizarem os exames necessários para diagnóstico, bem como, de "aconselhadores" genéticos (multiprofissionais da saúde) para ajudar tanto com a investigação inicial quanto com o acompanhamento das famílias (WHAM et al., 2010; COSTA et al., 2013). A maior parte dos treinamentos são realizados nos departamentos de genética médica das universidades (WHAM et al., 2010; BURTON et al., 2010).

0 aconselhamento genético é geralmente oferecido por médicos geneticistas e profissionais de saúde de diferentes origens. Estes prestadores de serviços genéticos geralmente estão associados à alguma sociedade de genética e ao conselho de sua profissão. Recentemente no Brasil, o Conselho Federal de Biologia editou a Resolução № 516/2019, que regulamenta a atuação de Biólogos na área de Aconselhamento Genético, reiterando que: 
[...] o Biólogo é um profissional legal e tecnicamente habilitado a atuar em atividades de Aconselhamento Genético, podendo exercer: levantamento da história familiar, elaboração e análise de heredogramas; estimativa de riscos de ocorrência e recorrência de doenças genéticas; identificação de pessoas ou famílias com risco genético potencial e encaminhamento a especialistas conforme fluxos estabelecidos em serviços de Saúde; assessoria técnica e consultoria, emissão de laudos e pareceres técnicos, realização de auditoria, fiscalização e gestão; entre outras atividades. A norma esclarece, no entanto, que não cabe ao Biólogo realizar diagnósticos e prognósticos clínicos, nem prescrição de tratamento de doenças genéticas, o que é fundamental para orientar todo o processo de aconselhamento genético (BRASIL, 2019).

Em 2014, foram instituídas duas portarias: A Portaria no 199 de 30 de janeiro:

Institui a Política Nacional de Atenção Integral às Pessoas com Doenças Raras, aprova as Diretrizes para Atenção Integral às Pessoas com Doenças Raras no âmbito do Sistema Único de Saúde (SUS) e institui incentivos financeiros de custeio.

Em 21 de maio, criou-se a Portaria no 981:

[...] que altera, acresce e revoga dispositivos da Portaria no 199/GM/MS, de 30 de janeiro de 2014, que institui a Política Nacional de Atenção Integral às Pessoas com Doenças Raras, aprova as Diretrizes para Atenção Integral às Pessoas com Doenças Raras no âmbito do Sistema Único de Saúde (SUS) e institui incentivos financeiros de custeio.

A referida portaria ainda estabelece que:

Art. 38-A. O procedimento de Aconselhamento Genético (código: 03.01.01.0226) descrito nesta Portaria e nos seus anexos poderá ser executado por equipe de saúde multiprofissional habilitada para a sua realização, conforme legislação específica sobre as profissões de saúde e regulamentação de seus respectivos conselhos profissionais, respeitados os critérios de habilitação.

Com as recentes diretrizes estabelecidas para atenção integral às doenças raras, após reivindicações feitas por muitas categorias profissionais e sociedades científicas, a resolução nacional de política de doenças raras incluiu formalmente geneticistas nãomédicos treinados em Aconselhamento Genético em saúde pública em equipes para fornecer aconselhamento genético, desde que coordenados por médicos capacitados no diagnóstico destas doenças. Nesse sentido, cursos de Aconselhamento Genético para profissionais de saúde estão sendo formulados e em breve serão implementados, em virtude de haver, hoje, poucos formalizados (GUEDES e DINIZ, 2009). Esses programas permitirão a formação de um maior número de profissionais, os quais, juntamente com os médicos geneticistas, garantirão melhor acesso aos serviços genéticos oferecidos em todo o país (GUEDES e DINIZ, 2009; ASHTON-PROLLA e SEUANEZ, 2016).

O Conselho Federal de Farmácia, por meio da Resolução № 570/2013, também regulamenta a atuação dos farmacêuticos na área de aconselhamento genético, salientando que: 
[...] são atribuições, na área de Genética Humana, nos segmentos de Aconselhamento Genético - diferenciar os diversos padrões de herança, analisar genealogia e padrão de herança, calcular o risco de recorrência para doenças gênicas, avaliar o melhor método de correção utilizado para calcular o risco de recorrência, anamnese do paciente, enumerar os principais métodos de diagnóstico clínico e laboratorial das anomalias genéticas, elucidação de casos clínicos, genética da infertilidade humana, detectar o aparecimento ou predisposição de doenças associadas a fatores hereditários ou genéticos em uma família, orientar sobre as possíveis formas de tratamento, prevenção, diagnóstico e probabilidade da doença ser transmitida a outros membros da família (BRASIL, 2013).

O Ministério da Saúde do Brasil publicou um decreto, em 2009, propondo a criação de uma Política Nacional de Atenção Integral à Genética Clínica no SUS (BRASIL, 2009). 0 Grupo de Trabalho (GT) teve como tarefa designada a elaboração da Política Nacional de Atenção Integral à Genética Clínica no SUS, levando em consideração a falta de regulação, padronização e as iniquidades regionais na atenção à saúde em genética clínica no país (FETT-CONTE et al., 2013). A coordenação do GT foi realizada pelo Departamento de Ciência e Tecnologia e pelo Departamento de Saúde (SAS) do Ministério da Saúde. Foi formado por representantes de diversos órgãos e entidades do Ministério da Saúde, da Sociedade Brasileira de Genética Médica (SBGM), da Sociedade Brasileira de Genética (SBG) e de serviços de referência em Genética Clínica (MOREIRA, 2012). Funcionou durante o período 2004 a 2006, com o objetivo de avaliar a situação do cuidado em genética clínica e promover um debate sobre as diversas instâncias do SUS, envolvendo gestores locais de saúde e prestadores de serviços, bem como obter subsídios para o desenvolvimento da política, foram realizadas diversas reuniões e oficinas regionais (Sul / Sudeste e Norte / Nordeste / Centro-Oeste). Representantes do Ministério da Saúde também participaram de inserções durante conferências genéticas clínicas (MOREIRA, 2012; FETT-CONTE et al., 2013; SILVA et al., 2013).

Esse processo resultou em uma proposta que acabou por levar à portaria $\mathrm{n}^{\mathrm{0}} 81$ do Ministério da Saúde, em 20 de janeiro de 2009, que instituiu a Política Nacional de Atenção Integral à Genética Clínica no SUS, e designou as estratégias para ações que devem ser levadas em consideração em sua regulamentação (BRASIL, 2010). Este foi um marco muito atrasado para os profissionais de genética médica no Brasil, redes de atendimento seriam estabelecidas com base nas ações das Secretarias de Saúde em conjunto com as múltiplas Secretarias Municipais de Saúde (BRASIL, 2009). 0 acordo entre os gestores estaduais e municipais de cada região determinaria a organização e forneceria as condições necessárias para a operação das redes. Tal organização teria que seguir diretrizes específicas propostas pelo Ministério da Saúde; o ministério também apoiaria a organização da rede financiando parcialmente o sistema (BRASIL, 2009).

De acordo com o proposto, a implementação dessa política seria progressiva, levando em conta as capacidades locais de organização da rede. 0 principal eixo estruturante para a atenção em saúde na genética clínica seria o aconselhamento genético, que deveria ser garantido a qualquer indivíduo ou família que necessitasse dele. Diretrizes de cuidados deveriam ser estabelecidas para investigar as condições mais frequentes, como deficiência intelectual, anomalias congênitas e erros inatos do metabolismo (ASHTON-PROLLA e SEUANEZ, 2016). Uma avaliação minuciosa do impacto financeiro da inclusão de testes genéticos específicos e de aconselhamento genético nos custos/financiamento da saúde seria realizada (KLATAU-GUIMARÃES et al., 
2014). Além disso, manuais e diretrizes deveriam ser desenvolvidos para orientar profissionais da Atenção Primária e Especializada. Todas essas iniciativas e outras medidas necessárias para a estruturação integral, o monitoramento e a melhoria da política seriam conferidos à Secretaria de Atenção à Saúde (SAS), que executaria essas ações por meio da constituição de um conselho técnico consultivo (SILVA et al., 2013).

\subsection{SERVIÇOS DE ACONSELHAMENTO GENÉTICO ONCOLÓGICO NO BRASIL}

No Departamento de Oncogenética do Hospital do Câncer de Barretos (HCB) é ofertado uma abordagem multidisciplinar (equipe composta por geneticistas clínicos e moleculares, oncologistas, patologistas, enfermeiros e psicólogos) e está integrada a todas as especialidades. As consultas são direcionadas a pacientes / familiares encaminhados por médicos de outras especialidades do Hospital (não é aberto a pacientes externos) (CARNESECA et al., 2013).

Neste hospital, o processo de aconselhamento genético consiste (principalmente) em duas visitas. Na primeira consulta, o enfermeiro oncogenético coleta informações sobre os hábitos e a saúde dos pacientes, além de informações sobre suas famílias para delinear o perfil do paciente. Após isso, o geneticista valida os dados da família, pesquisa as hipóteses diagnósticas e calcula o risco cumulativo de câncer (recorrendo aos modelos de cálculo de risco, tais como Ibis, Gail e Claus etc.), assim como a possibilidade prévia de ser portador de uma mutação deletéria (para famílias suspeitas de síndromes de predisposição de Mama Hereditária e Câncer de Ovário). Ademais, informações sobre o risco de câncer, sobre genética do câncer, prevenção e alternativas de redução do risco de câncer são esclarecidas ao paciente (CARNESECA et al., 2013).

Neste momento, o teste genético é oferecido a pacientes com critérios clínicos pré-estabelecidos e que demonstrem disposição para serem testados. 0 exame de sangue (para testes genéticos) pode ser realizado nessa consulta ou na próxima consulta, sempre sob explicação do consentimento informado. 0 fluxo de trabalho é dinâmico e pode variar de acordo com as necessidades de cada paciente (PALMERO et al., 2016). Enquanto na segunda visita ou terceir), o geneticista abordará os resultados dos testes genéticos (aconselhamento genético pós-teste), bem como as orientações para monitoramento e prevenção (cirurgias profiláticas e testes de acompanhamento) para pacientes e suas famílias. $\mathrm{O}$ acompanhamento posterior de cada indivíduo pode variar mensalmente, semestralmente e anualmente ou, eventualmente, não serão agendadas mais visitas. É importante ressaltar que o apoio psicológico é destinado a reconhecer e organizar possíveis incertezas advindas da situação de conflito instalada e avaliar como o paciente está vivenciando essa situação. O Departamento recebe assistência profissional do Departamento de Psicologia (PALMERO et al., 2016).

O serviço multiprofissional e interdisciplinar de aconselhamento genético (AG) da Liga Norte-riograndense Contra o Câncer (LNRCC) do estado do Rio Grande do Norte, atende pacientes de alto risco do Sistema Único de Saúde há mais de 10 anos. 0 serviço interdisciplinar de AG da LNRCC, conta com um médico oncologista, uma bióloga geneticista e uma psicóloga, que coletam informações clínicas importantes acerca da história pessoal e familiar do paciente e, em seguida, realizam testes moleculares disponíveis, onde buscam-se explicações sobre como as condições genéticas dos pacientes são transmitidas para as gerações seguintes, obtendo-se, desta forma, informações personalizadas a respeito das condições genéticas do paciente e das condutas clínicas necessárias para cada caso com base nos preceitos da Medicina 
Baseada em Evidência (SALES e LAJUS, 2018).

O Serviço de Genética da FAMERP/Hospital de Base está vinculado ao hospital escola e funciona buscando proporcionar eficácia no atendimento aos pacientes. Todo processo de AG desenvolvido no complexo FAMERP/ FUNFARME conta com suporte de uma equipe multidisciplinar envolvendo geneticista, psicólogo, pediatra, neurologia, ortopedia, oftalmologia, dermatologia, endocrinologia, assistente social, além de várias outras especialidades e corpo médico que o Hospital de Base disponibiliza em seu ambulatório e hospital. O Serviço possui grupos específicos de suporte e pesquisa à Síndrome de Down, Neurofibromatose, oncologia e medicina fetal. Além disso, a equipe está associada a outros grupos especializados de outras instituições de ensino, pesquisa e serviços de extensão à comunidade que colaboram com o diagnóstico e suporte aos familiares e portadores de afecções genéticas (BERTOLLO et al., 2013).

Observa-se que os avanços científicos e tecnológicos estão revolucionando a abordagem da avaliação genética de risco de câncer, rastreamento, prevenção do câncer e terapia direcionada, possibilitando a prática de medicina mais personalizada. Os desafios do aconselhamento genético oncológico observados incluem a necessidade de atualização profissional em genética e treinamento de equipes multidisciplinares, a necessidade de informações baseadas em evidências sobre a utilidade clínica de testes para variantes genômicas, os perigos potenciais colocados pelo marketing prematuro de perfis genômicos de primeira geração, e a necessidade de novos modelos clínicos para melhorar o acesso e a comunicação responsável de informações complexas sobre riscos de doenças. Dadas as experiências e lições aprendidas na era da genética, o modelo multidisciplinar de avaliação e gestão de risco genético de câncer deverá servir como base sólida para apoiar a integração de informações genômicas personalizadas na prática da medicina oncológica (WEITZEL et al., 2011).

\section{CONCLUSÃO}

Os dados do presente estudo mostram que o câncer ainda é uma doença muito estigmatizada para a população em geral e, portanto, não se deve subestimar quaisquer esforços que possam gerar condições adequadas para amenizar o sofrimento decorrente dessa doença. Considerando que profissionais de saúde podem servir como navegadores, guiando o paciente durante sua jornada de câncer, pode haver uma necessidade crítica de pesquisa em aconselhamento genético oncológico, para avaliar qual modelo de aconselhamento genético é mais apropriado para diferentes situações, e quais provedores precisam estar envolvidos no processo de aconselhamento. Com esse fim, pode surgir uma abordagem mais personalizada para o aconselhamento genético em predisposição hereditária ao câncer que tem aplicação crescente nessa era da medicina personalizada. 


\section{REFERÊNCIAS}

INCA. Instituto Nacional de Câncer José Alencar Gomes da Silva. [Internet] Incidência de câncer no Brasil. Estimativa 2018 [citado 2019 Mar 19] Disponível em: http://www1.inca.gov.br/estimativa/2018/introducao.asp

MOREIRA, R. M.; MELO, D. G. Percepções dos médicos a respeito do aconselhamento genético do câncer: o exemplo do câncer colorretal. Rev. Ciênc. Ext. 8(2): 46-65. 2012.

FLÓRIA-SANTOS, M., et al. Práctica de lo enfermero en oncología en la perspectiva de la genética y genómica. Texto contexto - enferm. 22(2): 526-533. 2013.

LAJUS, T. B. P. The importance to update the guidelines for the use of genetic testing in noncancer patients in Brazil. Rev Saude Publica. 49:2-5. 2015.

ABACAN, M., et al. The Global State of the Genetic Counseling Profession. Eur J Hum Genet. 5. 2018.

BARBOSA-BUCK, C. O., et al. Clinical epidemiology of skeletal dysplasias in South America.Am. J. Med. Genet. A. 158A :1038-1045. 2012.

FETT-CONTE, A. C., et al. Aconselhamento genético: definindo alguns problemas e soluções. Arq Ciênc Saúde. 20(1): 10-6. 2013.

SILVA, T. B., et al. Percepção de causas e risco oncológico, história familiar e comportamentos preventivos de usuários em aconselhamento oncogenético. Rev Esc Enferm USP. 47(2): 377-84. 2013.

MOREIRA-NUNES, C. A., et al. Genetic screening analysis of patients with hereditary diffuse gastric cancer from northern and northeastern Brazil. Hered Cancer Clin Pract. 12(1): 1-8. 2014.

BRASIL. Ministério da Saúde. Gabinete do Ministro. Portaria № 81, de 20 de janeiro de 2009. Institui, no âmbito do SUS, a Política Nacional de Atenção Integral em Genética Clínica. Diário Oficial da União da República Federativa do Brasil, Brasília, DF, 21 jan. 2009.

BRASIL. Ministério da Saúde. Portaria no 199, de 30 de Janeiro de 2014. [Internet] Diretrizes para atenção integral às pessoas com doenças raras no Sistema Único de Saúde. Brasília (DF); 2015 [citado 2019 Mar 29]. Disponível em: http://bvsms.saude.gov. br/bvs/saudelegis/gm/2014/prt0199_30_01_2014.html.

HOROVITZ, D. D., et al. Genetic services and testing in Brazil. J Community Genet. 4:355375. 2013.

KLAUTAU-GUIMARÃES, M. N.; PAIVA, S. G.; OLIVEIRA, S. F. Herança monogênica: além de Mendel, além do DNA. Genética na Escola. 9:2. 2014.

ASHTON-PROLLA, P.; SEUANEZ, H. N. The Brazilian hereditary cancer network: Historical aspects and challenges for clinical cancer genetics in the public health care system in Brazil. Genet Mol Biol. 39(2): 163-5. 2016. 
GUEDES C, DINIZ D. A Ética na História do Aconselhamento Genético: um Desafio à Educação Médica. Revista brasileira de educação médica. 33(2): 247-252. 2009.

MENDES A. Doenças hereditárias, aconselhamento genético e redes familiares e sociais: da ética intergeracional ao papel dos mais velhos. Revista Temática Kairós Gerontologia. 15(1): 199-216. 2012.

HERR, G. E., et al. Avaliação de conhecimentos acerca da doença oncológica e práticas de cuidado com a Saúde. Rev Bras Cancerol. 59(1): 33- 41. 2013.

EL RHAZI, K., et al. Public awareness of cancer risk factors in the Moroccan population: A population-based cross-sectional study. BMC Cancer. 14(1): 695. 2014.

HOROVITZ, D. D., et al. Genetic services and testing in Brazil. J Community Genet. 4:355375. 2013.

MARQUES-DE-FARIA, A. P., et al. Clinical genetics in developing countries: the case of Brazil. Community Genet. 7(2-3): 95-105. 2003.

MELO, D. G e SEQUEIROS, J. The challenges of incorporating genetic testing in the unified national health system in Brazil. Genet Test Mol Biomarkers. 16: 651-655. 2012.

WHAM, D., et al. Assessment of clinical practices among cancer genetic counselors. Fam Cancer. 9(3): 459-468. 2010.

ACOSTA, A. X., et al. Proporcionando educação genética e aconselhamento genético para doenças raras no Brasil rural. J. Genet. Conselho. 22: 830-834. 2013.

BURTON, A. M., et al. Health and lifestyle behaviors among persons at risk of Lynch syndrome. Cancer Causes Control. 21(4): 513-21. 2010.

BRASIL. Conselho Federal de Biologia. [Internet] Resolução № 516/2019. [citado 2019 Ago 07]. Disponível em: http://www.in.gov.br/web/dou/-/resolucao-n-520-de-9-deagosto-de-2019-210508061

BRASIL. Conselho Federal de Farmácia. [Internet] Resolução № 570/2013. [citado 2019 Ago 07]. Disponível em: http://www.cff.org.br/userfiles/file/resolucoes/570.pdf

ABRAMS, D. J.; GEIER, M. R. A comparison of patient satisfaction with telehealth and onsite consultations: a pilot study for prenatal genetic counseling. J Genet Couns.15(3): 199-205. 2006.

MACKAY, J.; TAYLOR A. Moving genetics into clinical cancer care: examples from BRCA gene testing and telemedicine. Breast. 15(Suppl 2):S65-S70. 2006.

ZON, R. T., et al. American Society of Clinical Oncology policy statement: the role of the oncologist in cancer prevention and risk assessment. J Clin Oncol. 27(6): 986-993. 2009.

PALMERO, E I., et al. Oncogenetics service and the Brazilian public health system: the experience of a reference Cancer Hospital. Genet. Mol. Biol. 39(2): 168-177. 2016.

CARNESECA, E. C., et al. The Hospital de Câncer de Barretos Registry: An analysis of 
cancer survival at a single institution in Brazil over a 10-year period. BMC Res Notes 6:e141. 2013.

SALES, L. A. P.; LAJUS, T. B. P. Aconselhamento genético em oncologia no Brasil: realidade e perspectivas. Rev Med (São Paulo). 97(5): 448-53. 2018.

BERTOLLO, E. M., et al. O processo de Aconselhamento Genético. Arq Ciênc Saúde. 20(1): 30-6. 2013.

WEITZEL, J. N., et al. Genetics, Genomics, and Cancer Risk Assessment: State of the Art and Future Directions in the Era of Personalized Medicine. CA Cancer J Clin. 61 (5): 32759. 2011. 


\section{Capítulo 8}

\section{Qual é a importância do enfermeiro auditor para a melhoria da qualidade de assistência à saúde?}

\section{Karine Garcez, Mc Comb}

\section{Sabrina da Fonseca Meireles}

Francimeire Gomes Pinheiro

Resumo: A importância da prática do enfermeiro auditor para a melhoria da assistência à saúde nas instituições públicas e privadas tem despertado interesse, à luz das responsabilidades administrativas que vem evoluíndo em resposta às necessidades institucionais, mercadológicas e assistenciais. Considerando as incumbências do auditor em enfermagem na avaliação de prontuários e nas contas hospitalares, prospôs-se a realização de um levantamento bibliográfico sobre a importância das atribuições do enfermeiro auditor para a melhoria da assistência à saúde. Para tanto, pesquisas nas bases de dados virtuais foram realizadas, resultando na identificação de 12 trabalhos sobre a temática. Destes, apenas nove foram incluídos na redação da revisão, os quais confirmam a importância da prática do enfermeiro auditor nas instituições, tanto para a melhoria da qualidade no serviço de assistência ao paciente, quanto à equipe de enfermagem.

Palavras-chave: Auditoria, Enfermagem, Gestão em Saúde, SUS. 


\section{INTRODUÇÃO}

O progresso científico e as inovações tecnológicas têm contribuído para mudanças em todas as áreas da saúde, modificando conceitos de qualidade na assistência à saúde e melhorando o desempenho das equipes de enfermagem nas instituições hospitalares. As responsabilidades administrativas têm evoluído em resposta às necessidades institucionais, mercadológicas e assistenciais, tornando decisivo o papel do enfermeiro para o cuidado efetivo e com qualidade do paciente (MARQUIS e HUSTON, 2005).

No Brasil, as atividades de auditoria na área da saúde iniciaram em 1968 para a prestação de assistência médica, por meio de atividades promovidas pelo Banco Central do Brasil (RIOLINO e KLIUKAS, 2003). Desde então, a auditoria vem sendo aplicada com diferentes propósitos, sendo na enfermagem, denominada por Auditoria de Enfermagem (AE), especialidade que promove a análise e avaliação de prontuários e contas hospitalares, contribuindo para o aperfeiçoamento da assistência nas instituições de saúde, pública ou privada (SCARPARO et al., 2010; MONTEIRO e PAULA, 2019).

A auditoria é um instrumento de administração, utilizada na avaliação da qualidade do cuidado; é a comparação entre a assistência prestada e os padrões de assistência considerados como aceitáveis (DUNN e MORGAN apud POSSARI, 2005). Em saúde, tem como objetivo a avaliação sistemática, analítica, pericial e formal de uma atividade por alguém não envolvido diretamente na sua execução, para determinar se essa atividade está sendo realizada conforme os objetivos estabelecidos (FERREIRA, 2001). No entanto, no âmbito do Sistema Único de Saúde (SUS), a auditoria é considerada complexa, por demandar informações que necessitam ser extraídas, analisadas e interpretadas com atenção, uma vez que há interesses e responsabilidades diversas quando se audita a saúde (BRASIL, 2011).

O enfermeiro auditor (EA) atua em instituições de saúde, pública e privada, promovendo a análise e avaliação de prontuários e contas hospitalares, dentro e fora da unidade, para garantir assistência de qualidade e melhor custo-benefício dos serviços de saúde (FELDMAN et al., 2005). Ademais, o auditor, por meio da avaliação sistemática dos registros de enfermagem, avalia a qualidade da assistência, monta o processo de cobrança da conta hospitalar, analisa as conformidades ou não com os gastos hospitalares (ROTHBARTH et al., 2009).

Nesse processo, a qualidade dos registros de enfermagem e a própria apresentação do prontuário, permite ao EA analisar de forma contínua e integralmente, o serviço prestado ao paciente, desde a admissão até a alta hospitalar (KURCGANT, 1991). Nessa perspectiva, propôs-se a realização de uma revisão descritiva sobre a importância do profissional enfermeiro auditor nas instituições de saúde, por meio de um levantamento na literatura científica.

\section{REFERENCIAL TEÓRICO}

\subsection{AUDITORIA NA SAÚDE}

A palavra auditoria vem do latim (audire, que significa ouvir), no entanto, pode ser melhor compreendida pelo termo "audit" do inglês, que tem o sentido de corrigir, examinar e certificar (DIAS et al., 2011). É um ramo da contabilidade utilizada em diversas profissões como ferramenta para mensurar qualidade (auditoria de cuidados) e custo (auditoria de custos) de instituições de saúde. (SILVA et al., 2016). De acordo com 
Caleman et al. (1998), o termo "audit" foi proposto para os serviços de saúde, pela primeira vez, em 1956, por Lambeck, com a finalidade de avaliar a qualidade dos processos e resultados desses serviços, por meio da observação direta do registro e da história clínica do usuário.

No Brasil, o Sistema Nacional de Auditoria (SNA) foi estabelecido pela Lei 8080, como um mecanismo de controle técnico e financeiro, para regular as ações e os serviços de saúde em todo o território nacional, sob competência do Sistema Único de Saúde (SUS) em cooperação com os estados, Distrito Federal e municípios. No entanto, a instituição do SNA se deu apenas pelo art. 6º da Lei 8689, de 27 de julho de 1993 (BRASIL/MS, 1993), e sua regulamentação, como o órgão responsável pela auditoria no âmbito do SUS, ocorreu em 28 de setembro de 1995, por meio do Decreto-lei 1651 (BRASIL/SF, 1995), que define auditoria como "análise prévia, concomitante ou subsequente da legalidade dos atos da administração orçamentária, financeira e patrimonial, bem como a regularidade dos atos técnico-profissionais, praticados por pessoas físicas e jurídicas". A instituição desse sistema de auditoria, desde então, tem sido considerada como um importante instrumento para a manutenção e o desenvolvimento do SUS (MELO, 2007).

De acordo com Ferreira (2001), a auditoria na saúde tem por finalidade a avaliação sistemática, analítica, pericial e formal de uma atividade por alguém não envolvido diretamente na sua execução, a fim de verificar se a atividade está sendo realizada conforme os objetivos propostos. Para o Ministério da Saúde (BRASIL, 2001, p. 9) a auditoria consiste no:

exame sistemático e independente dos fatos obtidos através da observação, medição, ensaio ou outras técnicas apropriadas, de uma atividade, elemento ou sistema, para verificar a adequação aos requisitos preconizados pelas leis e normas vigentes e determinar se as ações de saúde, e seus resultados estão de acordo com as disposições planejadas.

Em resumo, a auditoria tem como objetivo maior, propiciar à cúpula administrativa informações úteis ao exercício de um controle efetivo sobre a organização ou sistema, contribuir para o planejamento e replanejamento das ações e para o aperfeiçoamento do sistema (BRASIL, 2001; SANTANA e SILVA, 2009).

\subsection{A FUNÇÃO DO ENFERMEIRO AUDITOR}

A Auditoria de Enfermagem (AE), é uma especialidade que promove a análise e avaliação de prontuários e contas hospitalares, contribuindo para o aperfeiçoamento da assistência nas instituições de saúde, pública ou privada (SCARPARO et al., 2010; MONTEIRO e PAULA, 2019). 0 enfermeiro realiza essa função desde 1986, oficialmente, conforme a Lei n. 7.498 do Exercício Profissional da Enfermagem e somente em 2001, o Conselho Federal de Enfermagem (COFEN), por meio da Resolução COFEN no 266/2001, reconheceu o enfermeiro auditor como profissional habilitado para esta função e estabeleceu suas atribuições, visando promover a qualidade da assistência ao paciente.

O enfermeiro auditor atua em instituições de saúde, pública e privada, por meio de atividades internas ou externas da unidade, para garantir assistência de qualidade e melhor custo-benefício dos serviços de saúde (FELDMAN et al., 2005; LINS, 2011). A realização da auditoria pelo enfermeiro exige diversos deveres, dentre elas atuarem com ética, conhecer o contrato entre hospital e operadoras de planos de saúde, estar 
atualizado sobre os novos produtos no mercado, ser claro e conciso, conhecer detalhadamente o prontuário do paciente (ANDREOTTI, 2017). Entre as atividades do enfermeiro como auditor está a organização, direção, planejamentos, coordenação, avaliação, prestação de consultório e emissão de parecer sobre os serviços prestados à saúde (BARRETO et al., 2014).

De acordo com Possari (2005), a AE é a análise crítica e sistemática da qualidade da assistência de enfermagem prestada aos pacientes, ocorrendo a comparação do atendimento prestado com os padrões de atendimento, juntamente com a utilização de recursos previamente estabelecidos e o impulso para mudanças no padrão atual sempre que for necessário. As auditorias utilizadas no serviço de enfermagem incluem avaliações de resultado, de processo e de estrutura (MARQUIS e HUSTON, 2005) e está respaldada por uma vasta legislação, que abrange também as suas diversas áreas de atuação, subsidiando os diversos órgãos, governamentais e não-governamentais, para torná-los capazes de apoiar, cada vez mais, as atividades desenvolvidas pela enfermagem (MOTTA, 2003)

\section{MATERIAL E MÉTODOS}

Trata-se de uma pesquisa de revisão bibliográfica, conforme Gil (2008) baseada em livros, dissertações, teses e artigos científicos disponíveis nas bases de dados virtuais, consultados por meio dos descritores: auditoria, enfermagem e qualidade no serviço de saúde. Foram incluídos somente estudos completos, com resultados específicos ao tema, publicados no período compreendido entre 2010 e 2020.

\section{RESULTADOS E DISCUSSÃO}

Foram identificados 12 estudos utilizando os descritores pré-definidos na metodologia. Porém, alguns estudos estavam incompletos ou fora do tema proposto. Destes, nove trabalhos foram considerados para a redação desta revisão, conforme mostra a tabela abaixo.

Tabela 1. Resultados dos estudos realizados em auditoria em enfermagem identificados na literatura, com enfoque no título e na conclusão dos estudos.

\begin{tabular}{|c|c|c|}
\hline AUTOR & TÍTULO DO ARTIGO & CONCLUSÃO \\
\hline $\begin{array}{l}\text { 1. SILVA e } \\
\text { SPILLA, } 2006\end{array}$ & $\begin{array}{l}\text { Auditoria interna em } \\
\text { enfermagem e } \\
\text { educação continuada: } \\
\text { um feedback positivo. }\end{array}$ & $\begin{array}{l}\text { A auditoria tem grande relevância na sistematização da } \\
\text { assistência de enfermagem, sendo uma ferramenta } \\
\text { fundamental para a melhoria da saúde. }\end{array}$ \\
\hline $\begin{array}{l}\text { 2. SOUZA et } \\
\text { al., } 2010\end{array}$ & $\begin{array}{l}\text { Auditoria: uma } \\
\text { abordagem histórica e } \\
\text { atual. }\end{array}$ & $\begin{array}{l}\text { O serviço como auditor tem grande potencial com } \\
\text { habilidades capazes de desenvolver um bom trabalho na } \\
\text { auditoria em enfermagem. Destaca as atividades com } \\
\text { resultados satisfatório no serviço a saúde nas instituições. } 0 \\
\text { enfermeiro auditor trabalha com os outros profissionais e } \\
\text { sua equipe de enfermagem que colabora com sua gestão no } \\
\text { serviço à saúde. }\end{array}$ \\
\hline
\end{tabular}


Tabela 1. Resultados dos estudos realizados em auditoria em enfermagem identificados na literatura, com enfoque no título e na conclusão dos estudos. (continuação)

AUTOR TÍTULO DO ARTIGO CONCLUSÃO

3. FONSECA e Auditoria e qualidade A auditoria de enfermagem tem grande relevância enquanto ATONTONEL da assistência de ferramenta para a melhoria do serviço de assistência à 0, 2011 enfermagem: o elo saúde nas instituições. necessário.

\begin{tabular}{|l|lr|l|}
\hline 4. DIAS et al., & $\begin{array}{l}\text { Auditoria } \\
\text { enfermagem: } \\
\text { sistemática }\end{array}$ & $\begin{array}{r}\text { em } \\
\text { literatura. }\end{array}$ & da \\
& $\begin{array}{l}\text { Nas análises das publicações desta pesquisa constam as } \\
\text { conformidades e inconformidades presentes nos } \\
\text { prontuários de enfermagem. As inconformidades tem } \\
\text { trazido prejuízo para a assistência à saúde e para a } \\
\text { instituição. Foi demonstrado também a importância do } \\
\text { enfermeiro como auditor frente à administração e liderança } \\
\text { de equipe, confirmando que a auditoria é um processo de } \\
\text { contínua educação. }\end{array}$
\end{tabular}

\begin{tabular}{|c|c|c|}
\hline $\begin{array}{l}\text { 5. VIEIRA e } \\
\text { SANNA, } 2013\end{array}$ & $\begin{array}{lr}\text { Auditoria } & \text { de } \\
\text { enfermagem } & \text { em } \\
\text { periódicos } & \text { científicos } \\
\text { internacionais } & \text { no } \\
\text { período de } 1955-1972 .\end{array}$ & $\begin{array}{l}\text { A auditoria foi iniciada por comitês das quais incluíam } \\
\text { modificações nas descrições dos prontuários bem como nos } \\
\text { instrumentos de avaliação, o que ocasionou em um } \\
\text { resultado desanimador, as anotações eram superficiais ou } \\
\text { estereotipado no plano da enfermagem. }\end{array}$ \\
\hline $\begin{array}{l}\text { 6. BARRETO } \\
\text { et al., } 2016\end{array}$ & $\begin{array}{lr}\text { Inconsistências } & \text { das } \\
\text { anotações } & \text { de } \\
\text { enfermagem } & \text { no } \\
\text { processo de auditoria. }\end{array}$ & $\begin{array}{l}\text { Concluíram que há necessidade de investimento em } \\
\text { profissionais da enfermagem para a melhoria de seu } \\
\text { desempenho profissional na auditoria e respaldo diante das } \\
\text { questões jurídicas. }\end{array}$ \\
\hline $\begin{array}{l}\text { 7. SILVA et al., } \\
2016\end{array}$ & $\begin{array}{l}\text { Auditoria: ferramenta } \\
\text { de enfermagem para } \\
\text { melhoria da qualidade } \\
\text { assistencial. }\end{array}$ & $\begin{array}{l}\text { Foi verificado que a auditoria tem um papel importante em } \\
\text { avaliar o serviço à saúde do profissional de enfermagem; ao } \\
\text { paciente, pela análise dos prontuários, verificando as } \\
\text { incompatibilidades do procedimento e garantindo ao cliente } \\
\text { um preço justo nas cobranças geradas pela instituição } \\
\text { hospitalar. }\end{array}$ \\
\hline $\begin{array}{l}8 . \\
\text { ANDREOTTI, } \\
2017\end{array}$ & $\begin{array}{l}\text { Auditoria concorrente } \\
\text { de enfermagem em } \\
\text { prestadores } \quad \text { de } \\
\text { assistência à saúde: } \\
\text { uma revisão integrativa } \\
\text { da literatura. }\end{array}$ & $\begin{array}{l}\text { Demonstra a importância do auditor em enfermagem nas } \\
\text { UTIs e nos centros cirúrgicos. O estudo demonstra também } \\
\text { as transformações na prestação de serviço dos auditores de } \\
\text { enfermagem mudando o processo de auditoria retrospectiva } \\
\text { para então auditoria concorrente e suas potencialidades no } \\
\text { serviço do enfermeiro auditor. }\end{array}$ \\
\hline $\begin{array}{l}\text { 9. } \text { MONTEIRO } \\
\text { e PAULA, } \\
2020\end{array}$ & $\begin{array}{l}\text { Auditoria e a prática do } \\
\text { enfermeiro auditor: } \\
\text { uma revisão integrativa } \\
\text { da literatura }\end{array}$ & $\begin{array}{l}\text { A auditoria de enfermagem é uma importante ferramenta de } \\
\text { gestão que é realizada frequentemente pelo enfermeiro } \\
\text { auditor, a partir do método retrospectivo dos dados no } \\
\text { prontuário do paciente, para promover controle de custos } \\
\text { operacionais que influenciam, direta e indiretamente, a } \\
\text { qualidade da assistência, lucratividade e sustentabilidade de } \\
\text { instituições de saúde. }\end{array}$ \\
\hline
\end{tabular}

A auditoria de enfermagem é uma área em ascensão, que vem sendo cada vez mais explorada pelo enfermeiro, devido a sua importância na qualidade da assistência e nos registros realizados pela equipe de enfermagem nos serviços de saúde, além da contínua exigência de atualizações para o enfermeiro auditor frente às inovações presentes no processo de trabalho da enfermagem (SIQUEIRA, 2014). 
Nesta revisão, os estudos analisados apresentaram a importância e eficácia do trabalho do enfermeiro auditor na sistematização da assistência aos enfermeiros e para a melhoria da qualidade de saúde nas instituições (SILVA, 2006; SOUZA et al., 2010; FONSECA, 2011; DIAS, 2011; SILVA, 2016; ANDREOTTI, 2017). Atualmente, os esforços para garantir a melhoria da qualidade da assistência têm sido um desafio para os serviços de enfermagem de instituições públicas e / ou privadas, assim como desenvolver novas propostas e métodos que permitam gerenciar o processo de trabalho e recursos relacionados a assistência (PASSOS et al., 2012).

Andreott et al. (2017) demonstram a importância do auditor em enfermagem nas UTIs e nos centros cirúrgicos. Em estudo semelhante, foi observado em uma UTI adulto geral com 23 pacientes, que apesar do roteiro de Auditoria Operacional de qualidade da assistência prestada ter recebido baixa avaliação, o item relacionado à utilização de equipamentos foi o melhor avaliado, alcançando índice desejável, felizmente, pois o item é extremamente importante em se tratando de UTI, setor que monitora diferentes órgãos dos pacientes constantemente (SILVA, 2013).

No contexto dos serviços de saúde, os profissionais de enfermagem são os maiores provedores de cuidados e representam a maior parcela no quadro de recursos humanos das instituições. Com isso, é possível afirmar que grande parte do produto final do atendimento à saúde depende da qualidade dos cuidados dispensados pelos profissionais da enfermagem (SILVA et al., 2012). Dentre as intervenções do enfermeiro auditor observada nos estudos revisados, está a verificação de conformidades e inconformidades dos prontuários dos pacientes, o que pode gerar cobranças injustas para o paciente, dar prejuízo para a instituição ou até mesmo gerar questões jurídicas (DIAS, 2011; SILVA, 2016; BARRETO et al., 2016).

Apesar da eficácia da auditoria, esta ainda não se apresenta isenta de erros, pois a falta de conhecimento e / ou experiência, pode levar o profissional à questões judiciais, necessitando de respaldo diante de sua atuação. Vieira (2013) enfatiza a necessidade de investimentos e treinamentos na capacitação dos profissionais de saúde, para que haja melhora nos serviço de cuidados e que os mesmos possam ter respaldo diante dos aspectos éticos e jurídicos.

\section{CONCLUSÃO}

Os resultados deste levantamento bibliográfico, apontam para a relevância das atribuições do enfermeiro auditor para a melhoria da assistência à saúde nas instituições públicas e privadas, além de seus desafios no ambiente institucional. As práticas do enfermeiro auditor no controle, avaliação planejamento e coordenação, tornam-se primordiais para o alcance da melhoria do serviço prestado a população de forma geral. 


\section{REFERÊNCIAS}

ANDREOTTI, E.T. T. Auditoria concorrente de enfermagem em prestadores de assistência à saúde: uma revisão integrativa da literatura. RAS. 17 (68): 71-78. 2017.

BARRETO et al. Inconsistências das anotações de enfermagem no processo de auditoria. R. Enferm. Cent. O. 2016.

CALEMAN, G.; MOREIRA, M. L.; SANCHEZ, M. C. Auditoria, controle e programação de serviços de saúde. São Paulo: Fundação Petrópolis. 145p. 1998.

BRASIL. Ministério da Saúde. Departamento Nacional de Auditoria do Sistema Único de Saúde. Manual de Auditoria do SUS. Brasília: Ministério da Saúde, 2001.

DIAS, T. C. L. et al. Auditoria em enfermagem: revisão sistemática da literatura. Rev Bras Enferm. 64 (5): 931-7. 2011.

FERREIRA, A. B. de H. Miniaurélio Século XXI: o minidicionário da língua portuguesa. 5 ed. Rio de Janeiro: Nova Fronteira. 2001.

FELDMAN, L. B.; GATTO, M. A. F.; CUNHA, I. C. K. O. História da evolução da qualidade hospitalar: dos padrões a acreditação. Acta Paulista Enfermagem. 18 (2): 213-239. 2005.

FONSECA, M. R. A.; COSTA, F. Auditoria e qualidade da assistência de enfermagem: o elo necessário. Revista Intellectus. 29: 01. 2011.

GIL, Antonio Carlos. Como elaborar projetos de pesquisa. 4. ed. São Paulo: Atlas, 2008.

KURCGANT, P. Administração em enfermagem. São Paulo, SP: EPU. 1991.

LINS, L. S. Auditoria: uma abordagem prática com ênfase na auditoria externa: atualizado pelas leis 11.638/07 e 11.941/09 - São Paulo: atlas. 2011.

MARQUIS, B. L.; HUSTON, C. J. Administração e liderança em Enfermagem: teoria e aplicação. 4 ed. Porto Alegre: Artmed. 2005.

MELO, M. B. O Sistema Nacional de Auditoria do SUS: estruturação, avanços, desafios e força de trabalho. Tese. Programa de pós graduação da Fundação Osvaldo Cruz. 218p. 2007.

MONTEIRO, M. B. DA S.; PAULA, M. A. B. Auditoria e a prática do enfermeiro auditor: uma revisão integrativa da literatura. Rev. gest. sist. saúde., São Paulo. 9 (1): 71-93. 2020.

MOTTA, A. L. C. Auditoria de Enfermagem nos hospitais e operadoras de planos de saúde. São Paulo: Iátria. 2003.

PASSOS, M. L. L., et al. Auditoria de Enfermagem: Conhecimento de profissionais em hospital público de referência. In: Rev. Rene. 13 (5): 1025-33. 2012.

POSSARI, J. F. Prontuário do paciente e os registros de Enfermagem. São Paulo: Iátria, 2005. 
RIOLINO, A. N.; KLIUKAS, G. B. V. Relato de experiência de Enfermeiras no campo de auditoria de prontuário: uma ação inovadora. Revista Nursing. 6 (65): 35-38. 2003.

ROTHBARTH, S.; WOLFF, L. D. G.; PERES, A. M. O desenvolvimento de competências gerenciais do enfermeiro na perspectiva de docentes de disciplinas de administração aplicada à enfermagem. Texto Contexto Enfermagem. 18 (2): 321-329. 2009.

SCARPARO, A. F.; FERRAZ, C. A.; CHAVES, L. D. P.; GABRIEL, C. S. Tendências da Função do Enfermeiro Auditor no Mercado em Saúde. Texto e Contexto Enfermagem. 19 (1): 8592. 2010.

SILVA, K. R. et al. Auditoria: ferramenta de enfermagem para melhoria da qualidade assistencial. Rev. Gest.Saúde(Brasília). 7 (2): 793-10. 2016.

SILVA, P. C. C.; SPILLA, E. C. G. Auditoria interna em enfermagem e educação continuada: um feedback positivo. Rev Enferm. UNISA. 2006.

SIQUEIRA, P. L. F. Auditoria em saúde e atribuições do enfermeiro auditor. Caderno Saúde e Desenvolvimento. 4 (2): 5-19. 2014.

SOUZA, L. A. A. et al. Auditoria: uma abordagem histórica e atual. 72 (12): 47. 2010.

VIEIRA, R. Q.; SANNA, M. C. Auditoria de enfermagem em periódicos científicos internacionais no período de 1955-1972. Rev Enferm UFSM. 3 (3): 528-538. 2013. 


\section{Capítulo 9}

O estudo das plantas alimentícias não convencionais no Brasil: Uma revisão sistemática

\section{Jamile da Silva Brito \\ Francimeire Gomes Pinheiro \\ Sabrina da Fonseca Meireles \\ Bruno Bezerra Jensen}

Resumo: As plantas alimentícias não convencionais (PANCs) apresentam grande potencial nutritivo. Considerando a biodiversidade da flora do Brasil e ainda, a falta de conhecimento da população acerca das plantas comestíveis. Foi realizado um levantamento na literatura científica sobre a catalogação de plantas alimentícias não convencionais e suas propriedades nutritivas. Para tanto, pesquisas nas bases de dados SCIELO, PUBMED, SCIENCE DIRECT e Periódico Capes foram realizadas, resultando em 12 estudos completos sobre a temática. Os dados incluem várias espécies de plantas com propriedades nutritivas, como fontes vitamínicas, proteicas, minerais e fibras, que podem ser incluídas na dieta da população e sinalizam para a necessidade da ampliação de estudos sobre as PANCs e a divulgação desse conhecimento à população, para inserção dessas plantas na dieta humana, tornando-a mais saudável e colaborando para a redução do desperdício de alimentos.

Palavras-chave: Alimentação saudável, Desperdício de alimento, Nutrição, PANCs, Plantas daninhas. 


\section{INTRODUCCÃO}

As plantas fazem parte da alimentação humana desde os tempos pré-históricos. Além de fazerem parte da culinária, também são utilizadas para fins terapêuticos (BARREIRA et al., 2015). As PANCs, plantas alimentícias não convencionais, são consideradas silvestres e de fácil crescimento, podendo ser cultivadas ou exóticas sem a necessidade de cuidados especiais, possuindo partes comestíveis a serem utilizadas na alimentação humana (KINUPP, 2007).

As PANCs estão entre as fontes de alimentos que se desenvolvem em ambientes naturais. 0 fato de muitas dessas plantas estarem em áreas manejadas por agricultores torna-se estratégia fundamental para o fortalecimento da soberania alimentar de muitas famílias (CRUZ-GARCIA e PRICE, 2011). No entanto, muitas dessas plantas, embora disponíveis a baixo custo, ainda são desconhecidas e subutilizadas por uma parcela significativa da população (KINUPP, 2007).

O consumo das PANCs pode ser uma estratégia para manter a diversificação alimentar, estimulando a manutenção da floresta. Se realizado de maneira sustentável, pode ser considerada uma forma de utilização com baixo impacto na agricultura, associada à conservação ambiental (KINUPP, 2007). No Brasil, diversas PANCs são utilizadas para consumo alimentar de muitas famílias, sendo as mesmas consumidas in natura, refogadas, em formas de doces e cocadas. Porém, ainda são poucos os estudos sobre o uso dessas plantas (KINUPP e BARROS, 2008; NASCIMENTO et al., 2013).

O consumo apenas do fruto das plantas alimentícias e o descarte das demais partes do vegetal, também podem ser classificadas como PANCs. Tal desperdício ocorre por falta de conhecimento da população sobre o valor nutricional que elas podem oferecer à saúde humana (KINUPP, 2007). Com a divulgação das partes potencialmente comestíveis dessas plantas, provavelmente o desperdício e os gastos com alimentos diminuiriam (REIS et al., 2015).

Nesse sentido, as PANCs poderiam ser uma alternativa para minimizar a carência de alimentos vegetais no Brasil. Considerando a biodiversidade de plantas na região amazônica, associado ao grande valor nutricional que elas podem contribuir na alimentação humana e ainda, a falta de conhecimento da população acerca das plantas comestíveis. Foi realizado um levantamento na literatura científica sobre a catalogação de plantas alimentícias não convencionais e suas propriedades nutritivas.

\section{REFERENCIAL TEÓRICO}

\subsection{AS PLANTAS NO CONTEXTO ALIMENTAR DOS BRASILEIROS}

Os alimentos de origem vegetal vêm sendo utilizados como fonte de alimentação desde a pré-história. Estima-se que o homem cultiva atualmente, cerca de 300 espécies de plantas. Destas, apenas 15 espécies (arroz, trigo, milho, soja, sorgo, cevada, cana-deaçúcar, beterraba, feijão, amendoim, batata, batata-doce, mandioca, coco e banana) representam 90\% da alimentação do mundo (PATERNIANI, 2001; MONTEIRO, 2014; REIFSCHNEIDER et al., 2015).

Existem aproximadamente, 390 mil espécies de plantas catalogadas no mundo (RBG, 2017). Destas, 46.097 são espécies nativas do Brasil (ZAPPI et al., 2015). Apesar dessa riqueza de plantas, a sua utilização como alimento é pouco explorada e em geral, não fazem parte do cardápio dos brasileiros (SOUZA et al., 2013); composto, principalmente por arroz, café, feijão e mandioca, este último, associado ao consumo 
regional. Diante disso, nota-se a valoração de poucas espécies, a maioria exótica em detrimento das inúmeras espécies nativas (TULER et al., 2019).

Nesse cenário, esforços públicos para estimular uma alimentação mais saudável foi observado nos últimos anos, como a Política Nacional de Segurança Alimentar e Nutricional - PNSAN (2010), a Política Nacional de Alimentação e Nutrição - PNAN (2012) e a última edição do Guia Alimentar para a População Brasileira (BRASIL, 2014), por exemplo. 0 guia alimentar, trouxe uma proposta de orientação acerca da combinação de alimentos na forma de refeições e o reconhecimento da alimentação de maneira regionalizada, levando-se em consideração as características da culinária local, destacando aspectos relativos à cultura e identidade alimentar das macrorregiões do Brasil (CASEMIRO e VENDRAMINI, 2021).

No norte do país, região de grande biodiversidade de plantas no mundo, dentre as hortaliças, algumas poucas fazem parte da culinária regional, a saber: o jambu, Acmella oleracea (L.) da família Asteraceae, componente essencial do tacacá, prato típico da culinária amazônica; o cubiu (Solanum sessiliflorum Dun. - Solanaceae), conhecido em outras regiões por maná-cubiu ou simplesmente maná, o qual produz frutos que podem ser usados na caldeirada, iguaria nortista, no preparo de sucos, sorvetes, doces e geleias; e a chicória-de-caboclo (Eryngium foetidum L. - Apiaceae), utilizada como tempero essencial em pratos à base de peixes ou como ingrediente principal em bolinhos (tempurá) (KINUPP, 2007).

\subsection{PANCS COMO ALTERNATIVA ALIMENTAR}

As plantas alimentícias não convencionais (PANC), foram denominadas por este termo pela primeira vez no Brasil, pelo Biólogo e Professor Valdely Ferreira Kinupp em 2008. 0 termo PANC, refere-se as plantas que possuem uma ou mais partes edíveis, tais como: raízes, tubérculos, bulbos, rizomas, talos, folhas, flores, frutos e sementes; além de látex, resina e goma. Para Raniere (2017), as PANCs são plantas que não são produzidas ou comercializadas em grande escala. Essas plantas, muitas vezes desconhecidas são vistas como pragas ou ervas daninhas, porém possuem importante valor nutricional (NARCISO et al., 2017).

Em geral, as PANCs ainda não foram completamente estudadas e a sua biodiversidade é subestimada. A maioria são consideradas "mato" devido à ausência de conhecimento sobre o seu valor nutricional (REIS et al., 2015). A utilização do recurso dessas plantas pode ser de extrema importância para saúde, pois são ricas em vitaminas, minerais e fibras, além de serem de fácil cultivo (BREDARIOL, 2015). No entanto, apesar dos esforços em catalogar e classificar o valor nutricional dessas plantas, ainda não existe uma lista completa com suas descrições, o que facilitaria a divulgação e utilização delas na alimentação.

Para Kelen et al. (2015) as PANCs geram autonomia para o ser humano que deseja buscar por suas próprias mãos os nutrientes que necessita e os sabores que mais lhe agradam. Essas plantas são alimentos funcionais em nosso organismo por meio de vitaminas essenciais, antioxidantes, fibras e sais minerais, que nem sempre são encontradas em outros alimentos convencionais. A planta Dente-de-leão (Taraxacum officinale) da família Asteraceae é um exemplo, apesar de não ser nativa do Brasil, as suas folhas e raízes são comumente utilizadas na alimentação, devido ao alto teor de nutrientes, ricos em vitaminas A, B e C, além de ferro e potássio (Tabela 1). 
Tabela 1. Comparação entre o Dente-de-Leão e a Alface (valores por $100 \mathrm{~g}$ de peso seco).

\begin{tabular}{|l|c|c|}
\hline \multicolumn{1}{|c|}{ Elemento Nutricional } & Dente de Leão & Alface \\
\hline Proteínas & $2,7 \mathrm{f}$ & $0,84 \mathrm{~g}$ \\
\hline Lipídios & $0,71 \mathrm{~g}$ & $0,13 \mathrm{~g}$ \\
\hline Carboidratos & $8,8 \mathrm{~g}$ & $2,1 \mathrm{~g}$ \\
\hline Cálcio & $0,19 \mathrm{~g}$ & $0,04 \mathrm{~g}$ \\
\hline Fósfor & $70 \mathrm{mg}$ & $13,89 \mathrm{mg}$ \\
\hline Ferro & $3 \mathrm{mg}$ & $0,75 \mathrm{mg}$ \\
\hline Tiamina (B1) & $0,19 \mathrm{mg}$ & $0,03 \mathrm{~g}$ \\
\hline Roboflavina (B2) & $0,14 \mathrm{mg}$ & $0,06 \mathrm{mg}$ \\
\hline Niacina (B3) & $0,84 \mathrm{mg}$ & $0,13 \mathrm{mg}$ \\
\hline Vitamina C & $35,94 \mathrm{mg}$ & $12,57 \mathrm{mg}$ \\
\hline Vitamina A & $12662 \mathrm{UI}$ & $1115 \mathrm{UI}$ \\
\hline
\end{tabular}

Fonte: KELEN et al. 2015.

\section{MATERIAIS E MÉTODOS}

Esta revisão foi baseada na literatura especializada, selecionada por meio de buscas nas bases de dados científicos utilizadas no âmbito institucional, como: Scientific Eletronic Library Online - SCIELO (www.scielo.org), SCOPUS (www.scopus.com), SCIENCE DIRECT (www.sciencedirect.com) e Periódico Capes, a partir dos descritores: Plantas daninhas alimentícias, Plantas alimentícias não convencionais, Espécies vegetais comestíveis no Brasil.

Os critérios de inclusão foram: estudos relacionados as plantas comestíveis, a importância dos estudos dessas espécies e os valores nutricionais que elas proporcionam, no período compreendido entre 2007 e 2017. Foi considerado como critério de exclusão, estudos fora do período proposto e trabalhos com pouca incompletos. A estratégia de busca está descrita no fluxograma abaixo (Figura 1).

Figura 1. Fluxograma das etapas de busca, inclusão e exclusão de estudos da literatura.

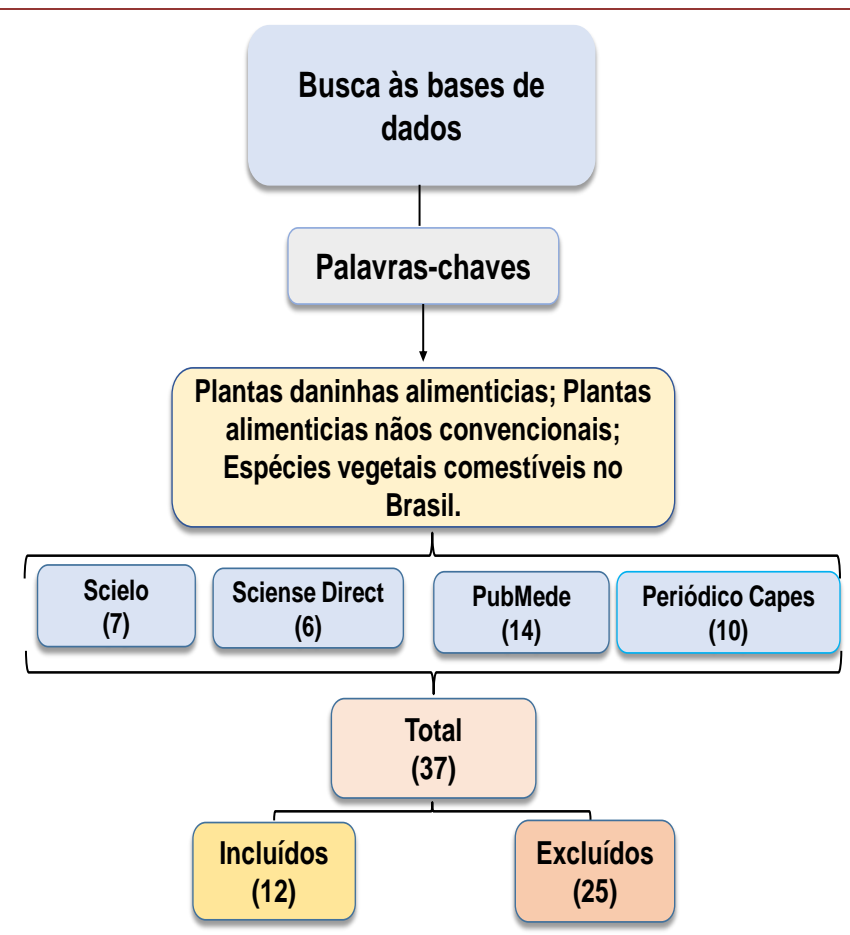




\section{RESULTADOS E DISCUSSÃO}

Foram encontradas 37 publicações, das quais 25 foram excluídas pelo fato de não corresponderem aos critérios de inclusão. Das pesquisas excluídas, 12 eram publicações antes do ano de 2007 e 25 não abordavam o tema proposto. Apesar da escassez de artigos publicados sobre as PANCs, foi possível identificar várias espécies de plantas com propriedades nutritivas, como fontes de vitaminas, proteínas, minerais e fibras, que podem ser incluídas na dieta (Tabela 2 ).

As plantas alimentícias são uma alternativa para a diversificação alimentar e cultural para as famílias. A planta Pereskia aculeata, da família Cactaceae, popularmente conhecida como Ora-Pro-Nóbis, por exemplo, tem despertado a atenção pelo seu valor nutricional, pois apresenta alto valor de proteína, fibras, ferro, cálcio e suas folhas, podem ser utilizadas nas saladas, omelete, refogados, massas (MUNDIN et al., 2007). Além de ter utilidade também na panificação e seus frutos, na preparação de sucos, geleias, mousse e licor (ALMEIDA e CORRÊA, 2011; ALMEIDA, 2012; KINUPP, 2014).

Atualmente, no Brasil a procura por alimentos não convencionais tem aumentado, a mandioca é consumida em demasia, no entanto, as suas folhas possuem alta concentração de proteína, e podem ser usadas na produção de farinha, juntamente com os talos primários e secundários (SILVA, 2007). Dependendo do manejo e idade da planta, as folhas podem apresentar um elevado teor proteico, entre 15 e $40 \%$ em massa seca, além de apresentar vitaminas e minerais (SILVA et al., 2012).

Outra planta alimentícia não convencional muito utilizada nas refeições é a Taioba (Xanthosoma sagittifolium Schott) - hortaliça folhosa originária das regiões tropicais da América do Sul. Apresentam folhas grandes e são ricas em vitamina C, ferro, potássio, cálcio e manganês (SILVA et al., 2015). Essa planta é consumida na forma de purês, cozidos e assados (LIMA, 2009). Apesar de suas folhas apresentarem um grande valor nutricional na alimentação humana, tem seu consumo pouco difundido no Brasil (MONTEIRO, 2011).

A hortaliça "bertalha" (Anredera cordifolia), conhecida como espinafre gaúcho, folha-gorda e folha-santa, tem ocorrência no Sul do Brasil, Paraguai e Argentina (MARTINEVSKI et al., 2013). É uma planta trepadeira, ricas em vitamina A e C (BOARI, 2016) que pode ser consumida em massa de pão, salada, refogados, omeletes e; suas folhas, secas e moídas são usadas como suplemento alimentar (KINUPP, 2014).

A capuchinha (Tropaeolum majus) é uma PANC originária do Brasil, com ocorrência no Peru, Colômbia, Sul do México e Patagônia, comumente conhecida por chaguinha, chagas, papagaios, flor-de-sangue, agrião-do-México, flor-de-chagas, esporade-galo, agrião-grande-do-Peru (BRASIL, 2010). Essa espécie é rica em vitamina C, antocianina, carotenoides e flavonoides, a qual pode ser consumida em formas de saladas, patês, pães, em sopas e refogados. Os seus frutos também podem ser preparados como alcaparra (em forma de conserva) e as sementes maduras, podem ser tostadas e moídas, substituindo a pimenta-do-reino (KINUPP, 2014).

A bucha vegetal (Luffa aegyptiaca Mill) originária da Ásia, Europa e América, foi cultivada no Brasil pelos portugueses. Atualmente, a sua produção perfaz a renda familiar de várias famílias (FERREIRA, 2009), e pode ser consumida em refolgados, empanados ou em sopas (KINUPP, 2014). Outra PANC, é a "erva-gorda" (Talinun paniculatum), que cresce espontaneamente em terrenos baldios e suas folhas são aromáticas e ricas em nutrientes, bastante usadas na alimentação humana, podendo ser 
consumidas fritas ou em refolgados (KINUPP, 2014).

Tabela 2. Resultado das buscas na literatura científica sobre as plantas alimentícias não convencionais (PANCs).

\begin{tabular}{|c|c|c|c|c|c|}
\hline Espécie & $\begin{array}{l}\text { Nome } \\
\text { Popular }\end{array}$ & $\begin{array}{c}\text { Parte } \\
\text { comestível }\end{array}$ & Receita & $\begin{array}{c}\text { Propriedades } \\
\text { nutricionais }\end{array}$ & Autor e Ano \\
\hline $\begin{array}{l}\text { Manihot } \\
\text { esculenta } \\
\text { Crantz }\end{array}$ & Mandioca & Folhas & Farinha & $\begin{array}{l}\text { Proteínas, } \\
\text { minerais, } \\
\text { aminoácidos e } \\
\text { vitaminas }\end{array}$ & $\begin{array}{l}\text { MOEST et al, } \\
\text { 2007 SILVA et } \\
\text { al., } 2012\end{array}$ \\
\hline $\begin{array}{l}\text { Pereskia } \\
\text { aculeata }\end{array}$ & $\begin{array}{l}\text { Ora-pro- } \\
\text { nóbis }\end{array}$ & $\begin{array}{l}\text { Folhas, } \\
\text { frutos e } \\
\text { brotos }\end{array}$ & $\begin{array}{l}\text { Sopa, } \\
\text { refolgados, } \\
\text { empanados, } \\
\text { fubá }\end{array}$ & $\begin{array}{l}\text { Proteína, } \\
\text { vitaminas e fibra }\end{array}$ & $\begin{array}{l}\text { ALMEIDA et al., } \\
2012\end{array}$ \\
\hline $\begin{array}{l}\text { Xanthosoma } \\
\text { taioba }\end{array}$ & Taioba & $\begin{array}{l}\text { Folhas, } \\
\text { talos e } \\
\text { rizomas }\end{array}$ & $\begin{array}{l}\text { Refolgada, } \\
\text { purê, rizomas } \\
\text { cozidos ou } \\
\text { fritos }\end{array}$ & $\begin{array}{l}\text { Vitamina } \mathrm{A}, \mathrm{C} \text {, } \\
\text { ferro, potássio e } \\
\text { manganês }\end{array}$ & $\begin{array}{l}\text { SOUZA, 2008; } \\
\text { KINUPP, } 2014\end{array}$ \\
\hline Basella alba & Bertalha & $\begin{array}{l}\text { Folhas e } \\
\text { túberas }\end{array}$ & $\begin{array}{l}\text { Patê, fritas, } \\
\text { pão. }\end{array}$ & $\begin{array}{l}\text { Vitamina A e C, } \\
\text { ferro, cálcio e } \\
\text { zinco }\end{array}$ & $\begin{array}{l}\text { BOARI, 2016; } \\
\text { KINUPP, } 2014\end{array}$ \\
\hline $\begin{array}{l}\text { Tropaeolum } \\
\text { majus L. }\end{array}$ & Capuchinha & $\begin{array}{l}\text { Folhas, } \\
\text { flores, } \\
\text { frutos, } \\
\text { sementes e } \\
\text { ramos, }\end{array}$ & $\begin{array}{l}\text { Patê, } \\
\text { panqueca, } \\
\text { pizzas, pães, } \\
\text { risoto e } \\
\text { sanduíches. }\end{array}$ & $\begin{array}{l}\text { Vitamina } C \text {, sais } \\
\text { minerais }(\mathrm{N}, \mathrm{S}, \mathrm{I} \text {, } \\
\mathrm{F}, \mathrm{K} \text { e P) }\end{array}$ & $\begin{array}{l}\text { CESSA, 2009; } \\
\text { KINUPP, } 2014\end{array}$ \\
\hline $\begin{array}{l}\text { Portulaca } \\
\text { oleracea }\end{array}$ & Beldroega & $\begin{array}{l}\text { Folhas, } \\
\text { ramos e } \\
\text { sementes }\end{array}$ & $\begin{array}{l}\text { Refolgados } \\
\text { Saladas. }\end{array}$ & $\begin{array}{l}\text { Vitamina B, C, } \\
\text { ácido linoleico, } \\
\text { tocoferol, } \\
\text { magnésio e zinco }\end{array}$ & $\begin{array}{l}\text { OLIVEIRA, 2014; } \\
\text { KINUPP, } 2013\end{array}$ \\
\hline $\begin{array}{l}\text { Talinun } \\
\text { paniculatum }\end{array}$ & Erva-gorda & $\begin{array}{l}\text { Folhas e } \\
\text { talos }\end{array}$ & $\begin{array}{l}\text { Cozidos e } \\
\text { refolgados }\end{array}$ & $\begin{array}{l}\text { Proteínas, ferro, } \\
\text { pró-vit. A e } \\
\text { antioxidante }\end{array}$ & $\begin{array}{l}\text { CASTRO, 2015; } \\
\text { KINUPP, } 2014\end{array}$ \\
\hline $\begin{array}{l}\text { Talinum patens } \\
\text { Wand }\end{array}$ & $\begin{array}{l}\text { Língua de } \\
\text { vaca }\end{array}$ & $\begin{array}{l}\text { Folhas e } \\
\text { brotos }\end{array}$ & $\begin{array}{l}\text { Saladas, } \\
\text { refolgados, } \\
\text { ensopados. }\end{array}$ & $\begin{array}{l}\text { Zinco, potássio, } \\
\text { ferro, cálcio, } \\
\text { magnésio. }\end{array}$ & $\begin{array}{l}\text { CARVALHO, } \\
2009 ; \\
\text { KINUPP, } 2014\end{array}$ \\
\hline $\begin{array}{l}\text { Typha } \\
\text { domingensis } \\
\text { Pers }\end{array}$ & Taboa & $\begin{array}{l}\text { Rizomas, } \\
\text { palmitos, } \\
\text { pólen. }\end{array}$ & $\begin{array}{l}\text { Sopa, } \\
\text { refolgados, } \\
\text { recheios. }\end{array}$ & $\begin{array}{l}\text { Vitamina } \mathrm{A}, \mathrm{C} \\
\text { lipídios, proteínas }\end{array}$ & $\begin{array}{l}\text { NASCIMENTO, } \\
2015 ; \\
\text { KINUPP, } 2014\end{array}$ \\
\hline $\begin{array}{l}\text { Jacaratia } \\
\text { spinosa }\end{array}$ & Jaracatiá & Frutos & $\begin{array}{l}\text { Doces, geleias, } \\
\text { mousse, } \\
\text { sorvete. }\end{array}$ & $\begin{array}{l}\text { Carotenoides, } \\
\text { vitamina A }\end{array}$ & $\begin{array}{l}\text { ABREU, 2015; } \\
\text { KINUPP, } 2014\end{array}$ \\
\hline $\begin{array}{l}\text { Acrocomia } \\
\text { aculeata }\end{array}$ & Macaúba & Frutos & $\begin{array}{l}\text { Geleias, } \\
\text { mousse, doces } \\
\text { e sorvetes. }\end{array}$ & Cálcio e potássio & $\begin{array}{l}\text { ARAGÃO, 2014; } \\
\text { KINUPP, } 2014\end{array}$ \\
\hline
\end{tabular}

Já a planta "beldroega" (Portulaca oleracea), conhecida como invasora, é pouco conhecida no Brasil, apesar de ser muito utilizada na Europa e África (OLIVEIRA et al, 2013). 0 consumo da beldroega é mais comum por crianças da zona rural, devido a sua fonte energética. Na China, os seus frutos são consumidos para anular a embriaguez de vinho; já as folhas, flores e sementes podem ser consumidas na forma de salada crua ou cozida (KINUPP, 2014). 
Existem outras PANCs descritas, como a jaracatiá (Jacaratia spinosa), iguaria gastronômica em uma comunidade de São Pedro - São Paulo (PROSPERO, 2010) que usam o fruto para seu sustento; a macaúba (Acrocomia aculeat) - palmeira que produz cachos de até 500 frutos cada, com semente e polpa comestíveis; a língua de vaca (Talinum patens Wand.), usada na Bahia no consumo alimentar e na recuperação do estado nutricional causado pela carência de ferro (CARVALHO, 2009); e por fim, a Taboa (Typha domingensis Pers.), utilizada na alimentação de animais das áreas semiáridas do Brasil (NASCIMENTO et al., 2014).

\section{CONCLUSÃO}

Os resultados desta revisão de literatura apontam para a importância do conhecimento e divulgação à população brasileira acerca das plantas alimentícias não convencionais no país. Embora seja alta a biodiversidade dessas plantas no Brasil, a escassez de informação sobre a sua utilização para fins alimentícios ou terapêuticos ainda são incipientes, e colabora para o desperdício de alimentos. Nesse sentido, sinaliza-se a necessidade da promoção de estratégias de divulgação da utilização na cultura alimentar de PANCs à população, para inserir essas plantas na dieta humana, favorecendo a melhoria da qualidade de vida.

\section{REFERÊNCIAS}

ABREU. H. Estudo nutricional, fitoquímico e biológico do "jaracatiá” Jacaratiaspinosa (Aubl.) (A.D.C). Dissertação (mestrado) Programa de Pós-Graduação em Segurança Alimentar e Nutricional, setor de Ciências da Saúde. Universidade Federal do Paraná. Curitiba, 2015.

ALMEIDA, M. E. F. Farinha de folhas de cactáceas do gênero Pereskia: caracterização nutricional e efeito sobre ratos wistar submetidos à dieta hipercalórica. Tese (doutorado) Universidade Federal de Lavras, MG. 126 p. 2012.

ALMEIDA, M. E. F; CORRÊA, A. D. Utilização de cactáceas do gênero Pereskia na alimentação humana em um município de Minas Gerais. Santa Maria, Ciência Rural. 42 (4): 751-756. 2012.

ARAGÃo, T. F. Macaúba (Acrocomia aculeata): caracterização centesimal, potencial antioxidante e compostos fenólicos da polpa e amêndoa. Trabalho de Conclusão de Curso. Campo Mourão, 2014.

BARREIRA, T. F., et al. Diversidade e equitabilidade de Plantas Alimentícias Não Convencionais na zona rural de Viçosa, Minas Gerais, Brasil. Revista. Brasileira. Pl. Med., Campinas.17 (4): 964-974. 2015.

BRASIL. Manual de hortaliças não convencionais/Ministério da Agricultura, Pecuária e Abastecimento. Brasília em um Sistema Agroflorestal no Município de Rio Claro - SP. Trabalho de conclusão de curso (Ecologia: MAPA, 92p. 2010.

BREDARIOL, L. R. Levantamento e caracterização das Plantas Alimentícias Não Convencionais (PANC'S) Espontâneas Presentes) - Universidade Federal Paulista, Instituto de Biociências de Rio Claro. Rio Claro, SP. 2015. 
CARVALHO, R. D. S. Caracterização química e avaliação de folhas de Talinum patens Wand como complemento alimentar. Tese (Doutorado) - Universidade Federal da Bahia, BA. 110p. 2009.

CASEMIRO, I. P.; VENDRAMINI, A. L. A. 10 anos de PANC (plantas alimentícias não convencionais) análise e tendências sobre o tema. Alimentos: Ciência, Tecnologia e Meio Ambiente. 2: 3. 2021.

FERREIRA, I. C. P. V. et al., Avaliação Participativa de Acessos de Bucha Vegetal. VI Congresso Brasileiro de Agroecologia. 2009.

KINUPP, V. F.; BARROS, B. I. Riqueza de Plantas Alimentícias Não-Convencionais na Região Metropolitana de Porto Alegre, Rio Grande do Sul. Revista Brasileira de Biociências, Porto Alegre. 5 (1): 63-65. 2007.

KINUPP, V. F.; BARROS, B. I. Teores de proteína e minerais de espécies nativas, potenciais hortaliças e frutas. Ciências Tecnologia Alimentar, Campinas. 28 (4): 846-857. 2008.

KINUPP, V. F.; LORENZI, H. Plantas Alimentícias Não Convencionais (PANC) no Brasil. São Paulo: Instituto Plantarum de Estudos da Flora, 2014.

LIMA, T. A. Caracterização de compostos nutricionais e antinutricionais em taiobas (Xanthosoma schott). Dissertação (mestrado) - Universidade de Brasília Instituto de Ciências Biológicas Programa de Pós-Graduação de Botânica. Brasília, 2009.

MARTINEVSKI, C. S.; et al. Utilização de Bertalha Anredera cordifolia (Ten.) Steenis e OraPro-Nobis (Pereskia aculeata Mill.) na elaboração de pães. Alim. Nutr. Braz. J. Food Nutr, Araraquara. 24 (3): 01-06. 2013.

MODEST, C. F.; CORRÊA, A. D.; OLIVEIRA, E. D.; ABREU, C. M. P.; SANTOS, C. D. Caracterização de concentrado proteico de folhas de mandioca obtido por precipitação com calor e ácido. Ciências Tecnologia Alimentar. Campinas. 27 (3): 464-469. 2007.

MONTEIRO, E. B. Caracterização química e estudo das propriedades funcionais biológicas in vivo da folha de taioba (Xanthosoma sagittifolium). Dissertação (mestrado) - Universidade Estadual de Campinas. Faculdade de Engenharia de Alimentos. Campinas, SP: [s.n], 2011.

MUNDIM, M. S.; SILVA, C. O.; ALVES, D. S.; TASSI, E. M. M. Estudo da composição centesimal e teste de aceitabilidade de picolés de limão com e sem Ora-Pro-Nobis (Pereskia aculeata Miller). 2007.

NASCIMENTO, J. M. L.; QUEIROS, M. A. A.; GOMIDE, G. A. G.; AMARAL, A. A.; FERRARI, J. L. Potencial nutricional de plantas de Typha domingensis Pers. como opção forrageira. Revista Brasileira de Ciências Agrárias. Recife. 9 (2): 290-294. 2014.

NASCIMENTO, J. M. L.; COSTA, F. R. L.; QUEIROS, M. A. A.; SANTOS, M. E. R. Crescimento e valor bromatológico de taboa sob condições semiáridas. Pesquisa Agropecuária Tropical., Goiânia. 45 (1): 97-103. 2015. 
OLIVEIRA, L. F.; et al. Utilização de casca de banana na fabricação de doces de banana em massa - avaliação da qualidade. Alim. Nutr., Araraquara. 20 (4): 581-589. 2009.

OLIVEIRA, D. C. S.; WOBETO, C.; ZANUZO, M. R.; SEVERGNINI, C. Composição mineral e teor de ácido ascórbico nas folhas de quatro espécies olerícolas não-convencionais. Hortic. bras. 31. 2013.

PATERNIANI, E. Agricultura sustentável nos trópicos. Estudos Avançados 15: 303-326. 2001.

REIS, K. T. M. G.; et al. Denvolvimento de tecnologias de fabricação de doces e geleias como tecnologias do aproveitamento integral (taia) de frutas, hortaliças e de plantas comestiveis não convencionais (PANCs). Congresso Nacional de Pesquisa e Ensino em Ciências. 2015.

RBG Kew The state of the world's plants report. Royal Botanical Gardens, Kew. 100p. 2017.

REIS, J. P. G.; et al. Estudo do emprego de plantas alimentícias não convencionais (PANCS): característica nutricional, propriedade funcional e emprego na alimentação humana. Congresso Nacional de Pesquisa e Ensino em Ciências. 2015.

REIFSCHNEIDER, F. J. B.; et al. Uma pitada de biodiversidade na mesa dos brasileiros. 17a ed. Brasília. 156p. 2015.

SILVA, J. L.; et al. Obtenção de concentrado proteico de folhas e parte aérea da mandioca (Manihot esculenta Crantz). Ciências Agrárias, Londrina. 33 (6): 2279-2288. 2012.

SILVA, T. L.; et al. Efeito da ingestão de farinha de taioba sobre o peso corporal de ratos previamente alimentados com óleo de soja e banha suína. Revista Saúde e Biologia.10 (2): 27-34. 2015.

SOUZA, C. S. Programação in vitro de gremoplasma de taioba (Xanthosoma sagittifolium (L.) SCHOTT). Dissertação - Universidade Federal de Virçosa - MG, 2008.

SOUZA, A. M.; et al. Alimentos mais consumidos no Brasil: inquérito nacional de alimentação 2008-2009. Revista de Saúde Pública 47: 190-99. 2013.

TULER, A. C.; et al. Plantas alimentícias não convencionais (PANC) na comunidade rural de São José da Figueira, Durandé, Minas Gerais, Brasil. Rodriguésia 70: e01142018. 2019.

ZAPPI, D.C.; et al. Epílogo. Rodriguésia 66: 2. 2015. 


\section{Capítulo 10}

\section{Aspectos nutricionais e desempenho escolar de crianças e adolescentes com malária na Região Amazônica - Uma revisão sistemática}

Sabrina da Fonseca Meireles

Grazielle Tayná Barbosa da Silva

Rubia Kezia Barroso da Cruz.

Francimeire Gomes Pinheiro

Resumo: A relação sinérgica entre malária e nutrição ainda é complexa e controversa. Considerando a importância da nutrição na manutenção da saúde, foi elaborado esta revisão de literatura, com o objetivo de consolidar as informações disponíveis nos artigos científicos entre 2000 e 2020 sobre o estado nutricional e o rendimento escolar de crianças e adolescentes com malária na região amazônica. Dos 41 artigos acessados, apenas nove estavam de acordo com à temática. Os achados foram raros, e reforçam a associação da malária ao comprometimento do estado nutricional de crianças em uma área endêmica da Amazônia por Plasmodium vivax, e ainda, aos altos níveis de parasitemia, anemia, e ao baixo desenvolvimento cognitivo em crianças. Nesse sentido, é necessário a realização de mais estudos, para sanar lacunas sobre a relação da malária com a desnutrição e com o comprometimento do rendimento escolar de crianças e adolescentes em outras áreas endêmicas por P. vivax e P. falciparum na Amazônia.

Palavras-chave: Anemia, Desenvolvimento Cognitivo, Nutrição, Paludismo. 


\section{INTRODUÇÃO}

A malária ou paludismo continua a ser uma das principais causas de infecção no mundo (MORGONO, 2015). Estima-se que 3,2 bilhões de pessoas correm risco de serem infectadas pela doença (OPAS, 2016). Somente em 2019, 228 milhões de casos de malária foram notificados no mundo, com 405.000 mortes confirmadas (WHO, 2019). Das cinco espécies de Plasmodium que causam a doença em humanos, Plasmodium falciparum e Plasmodium vivax representam maior ameaça, sendo o P. falciparum responsável pela maioria das mortes por malária no continente africano e $P$. vivax, o mais difundido geograficamente, responsável por $75 \%$ dos casos relacionados à malária na América Latina (PAHO, 2017).

No Brasil, nos últimos 40 anos a região amazônica é a principal área endêmica de malária, com mais de $99 \%$ dos casos registrados (CIVES, 2011). As condições socioeconômicas e ambientais da região propiciam a sobrevivência do vetor, mosquitos do gênero Anopheles e favorecem a transmissão do parasito (MESONES LAPOUBLE et al., 2013, LAPOUBLE et al., 2015). A doença afeta todas as faixas etárias e ambos os sexos, porém, as crianças apresentam maior risco de desenvolver sintomas mais graves devido à falta de resposta imunológica adequada (LADEIA-ANDRADE et al., 2009; FERREIRA et al., 2010; BENZECRY et al., 2016).

No processo infeccioso da malária, existem fatores intrínsecos ao hospedeiro, como estado nutricional e susceptibilidade inata à infecção (LADEIA-ANDRADE et al., 2009; LANCA et al., 2012; BENZECRY et al., 2016). Alguns estudos mostram que a nutrição pode influenciar a suscetibilidade à doença ou alterar o seu curso (SHANKAR, 2000; GENTON et al., 1998), outros sugerem que a desnutrição serve de proteção da apresentação dos sintomas da malária (GENTON et al., 1998; FILLOL et al., 2009).

Estudos na Amazônia brasileira mostram ingestão insuficiente de micronutrientes em populações nativas, apesar do alto teor de micronutrientes de frutas e peixes locais. Outro agravante é a anemia, umas das primeiras complicações que ocorre durante a infecção da malária (BREMAN; MURPHY, 2001, FERNANDO et al., 2002); e a malária cerebral em crianças, causando prejuízos significativos no desenvolvimento de habilidades cognitivas (MEREMIKWU, 1997; BOIVIN et al., 2002).

Os dados sobre o sinergismo entre (malária x nutrição) e (malária x rendimento escolar) em crianças e adolescentes na região amazônica são ainda incipientes, tanto para $P$. falciparum quanto para $P$. vivax. Nesse sentido, o entendimento claro dessas interações é necessário para o desenvolvimento e implementação de medidas de controle e programas de reabilitação mais eficazes nessa região, considerada área endêmica de malária. Esta revisão de literatura foi elaborada, para consolidar as informações disponíveis nos artigos científicos entre 2000 e 2020 sobre o estado nutricional e o rendimento escolar de crianças e adolescentes com malária na Amazônia brasileira.

\section{REFERENCIAL TEÓRICO}

\subsection{MALÁRIA E NUTRIÇÃO}

A malária é um dos principais problemas de saúde pública do mundo (OMS, 2012). Os protozoários responsáveis pela malária pertencem ao gênero Plasmodium, que são transmitidos de uma pessoa a outra pela picada do mosquito do gênero Anopheles. 0 A. darlingi é o principal vetor da malária na Amazônia, onde ocorre o maior número de 
casos. Existem cinco espécies de Plasmodium de importância clínica e epidemiológica, a saber: Plasmodium malariae, Plasmodium vivax, Plasmodium falciparum, Plasmodium ovale e, Plasmodium knowlesi. Destas, o P. vivax é o mais amplamente distribuído pelas zonas tropicais e subtropicais (WHO, 2014).

A malária frequentemente atinge populações empobrecidas e desnutridas, e uma grande parte do fardo da malária recai sobre os mais vulneráveis da população - as crianças e as mulheres grávidas (SHANKAR, 2000). A coexistência da malária com outras doenças prejudica ainda mais as populações afetadas e a desnutrição é uma das condições mais preocupantes (CUSTODIO et al., 2009). Acredita-se que as crianças com baixo peso tenham maior suscetibilidade à malária por uma série de razões, principalmente por meio de uma redução na função do sistema imunológico, pois quando uma criança está desnutrida, ela pode ser incapaz de montar uma resposta imunológica apropriada ao parasita da malária devido à redução nos linfócitos $\mathrm{T}$ (SCRIMSHAW et al., 1997).

As deficiências das vitaminas A, zinco, ferro, folato, bem como de outros micronutrientes, são responsáveis por uma proporção substancial da morbidade e mortalidade da malária. Sabe-se que a melhoria do estado nutricional diminui a gravidade dos episódios de malária e resulta em menos mortes (CAULFIELD et al., 2004). Ademais, a nutrição pode influenciar a suscetibilidade à doença ou alterar o seu curso (SHANKAR, 2000; GENTON et al., 1998). Por outro lado, a desnutrição serve de proteção da apresentação dos sintomas da malária, de acordo alguns estudos (GENTON et al., 1998; FILLOL et al., 2009).

\subsection{MALÁRIA CEREBRAL}

A malária cerebral por definição da Organização Mundial de Saúde (2000), é uma encefalopatia aguda e potencialmente reversível, caracterizada por coma e presença de formas assexuadas do P. falciparum em esfregaço sanguíneo, com exclusão de outras causas de encefalopatias, como meningite bacteriana e encefalites virais. Dentre suas formas graves, a malária pode acometer o cérebro com frequência entre 0,01\% e 16\% dos casos (TOSTA e LOPES, 2000) e, de 10 a 17\% dos que sobrevivem ao quadro de malária cerebral permanecem com algum déficit cognitivo e/ou comportamental após infecção (MURPHY e BREMAN, 2001).

Na África Subsaariana, a malária cerebral é considerada uma das principais causas de deficiência cognitiva em crianças, principalmente em crianças que apresentaram convulsões antes do tratamento (BOIVIN et al., 2007). A maioria das crianças que vivem em áreas endêmicas sofre múltiplos episódios de malária antes da adolescência. Em geral, esses episódios não são complicados, e as crianças se recuperam após o tratamento, especialmente em áreas onde o $P$. vivax é frequente (FERNANDO et al., 2006).

Dados na literatura mostram que o impacto da malária no desempenho cognitivo infantil após infecção por P. falciparum, nos quais ocorre a malária cerebral, é mais frequente e pode resultar em sequelas neurológicas graves (IDRO et al., 2010). Após um episódio agudo de infecção ocorre algum prejuízo no desenvolvimento de habilidades cognitivas, tanto a curto prazo (MEREMIKWU et al., 1997), como a longo prazo (CARTER et al., 2005). 


\section{METODOLOGIA}

\subsection{PROCEDIMENTOS METODOLÓGICOS}

Este estudo é uma revisão sistemática baseada na literatura especializada, selecionada por meio de buscas nas plataformas de pesquisa, como: Biblioteca Virtual em Saúde (BVS), os bancos de dados LILACS (Literatura Latino- Americana em Ciências de Saúde), Scielo, Science direct e, a MEDLINE (Medical Literature Analysis and Retrievel System Online). A última pesquisa foi realizada em dezembro de 2020, utilizando os descritores: Malária e nutrição em crianças e adolescentes na Amazônia; Malária e anemia em crianças e adolescentes na região amazônica; Malária e rendimento escolar na Amazônia. A sistematização dos estudos acessados está esquematizada na Figura 1.

Foram incluídos na redação da revisão, somente estudos completos realizados na região amazônica, com resultados específicos à abordagem nutricional em crianças e/ou adolescentes com malária e, estudos relacionados à infecção com o rendimento escolar. Apenas artigos publicados no período compreendido entre 2000 e 2020 foram considerados e nenhuma restrição de idioma foi aplicada.

Figura 1. Esquema em quatro etapas da metodologia para inclusão e exclusão dos estudos acessados nas plataformas de pesquisa científica, iniciando com 1identificação, 2- triagem, 3- elegibilidade e, 4- inclusão.

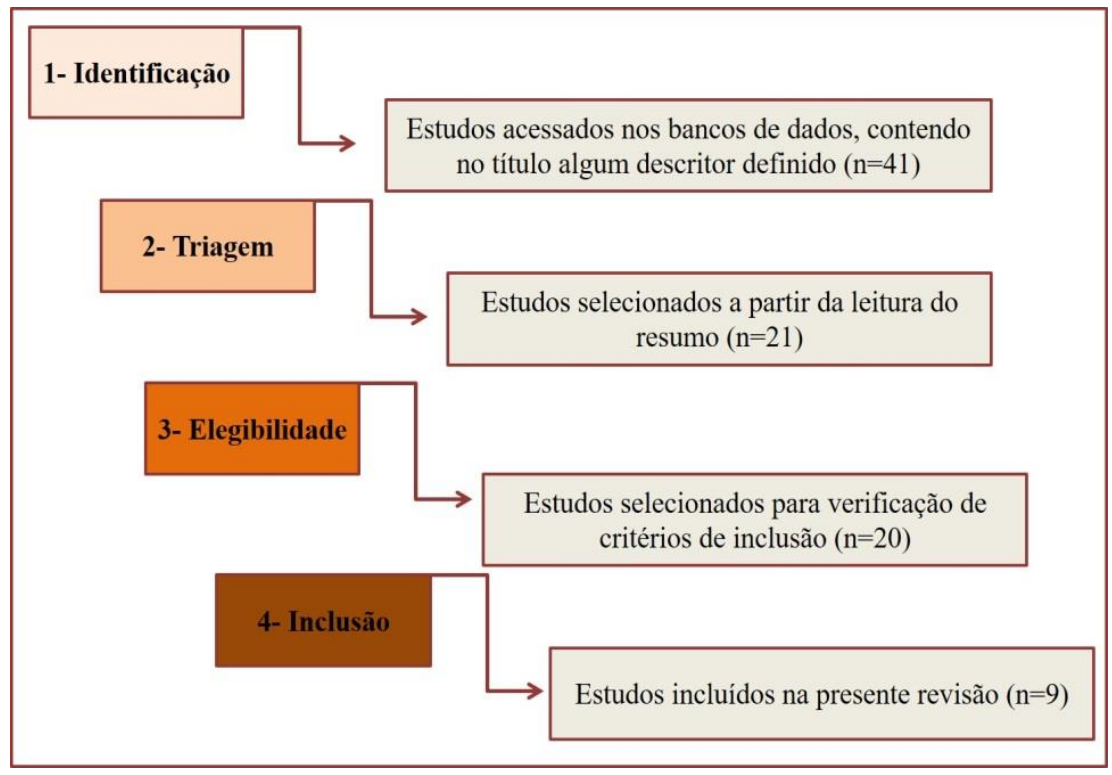

Fonte: dados dos autores

\section{RESULTADOS E DISCUSSÃO}

A busca nos bancos de dados permitiu o acesso a 41 artigos, contendo no título algum descritor definido na metodologia. Destes, 21 foram excluídos após a leitura dos resumos, pois não abordavam a temática proposta e / ou estavam fora do período estabelecido. Dessa forma, 20 artigos foram analisados criteriosamente e apenas 9 foram incluídos na redação final. Os trabalhos foram avaliados e estratificados em 2 grupos principais: no primeiro grupo foi incluído seis trabalhos que abordaram a relação entre malária e nutrição em crianças e adolescentes na região amazônica (Tabela 1); no segundo grupo, foi incluído apenas três estudos sobre a relação entre malária e rendimento escolar (Tabela 2). 
Tabela 1. Descrição de estudos realizados em crianças e adolescentes acometidas por malária na região amazônica, considerando os parâmetros: dados de autoria, objetivos e resultados das pesquisas.

\begin{tabular}{|c|c|c|c|}
\hline $\begin{array}{l}\mathbf{N} \\
\underline{\mathbf{o}}\end{array}$ & Autor/Ano & Objetivos dos estudos & Resultados \\
\hline 1 & $\begin{array}{l}\text { FERREIRA et } \\
\text { al., } \quad 2018 . \\
\text { DOI.org/10.17 } \\
\text { 058/reci.v1i2.8 } \\
377 .\end{array}$ & $\begin{array}{l}\text { Avaliar a situação } \\
\text { alimentar e nutricional de } \\
\text { crianças e adolescentes } \\
\text { com malária por P. vivax, } \\
\text { no município de } \\
\text { Anajás/PA. }\end{array}$ & $\begin{array}{l}\text { Dos } 60 \text { pacientes estudados, } 40(66,7 \%) \text { eram crianças } \\
(4,7 \pm 2,25 \text { anos). Os dados sociodemográficos dos responsáveis } \\
\text { mostraram que } 75,0 \% \text { viviam com até um salário-mínimo e } \\
23,3 \% \text { eram analfabetos. } \\
\text { Na avaliação do estado nutricional, } 25,0 \% \text { das crianças e } 15,0 \% \\
\text { dos adolescentes apresentavam baixa estatura/idade. Quanto } \\
\text { ao consumo alimentar, apenas os grupos de cereais, raízes e } \\
\text { tubérculos }(80,0 \%) \text {, óleos e gorduras }(78,3 \%) \text { e carnes, } \\
\text { pescados e ovos }(73,3 \%) \text { estavam adequados. }\end{array}$ \\
\hline 2 & $\begin{array}{l}\text { BENZECRY et } \\
\text { al., } \quad 2016 . \\
\text { DOI.org/10.13 } \\
\text { 71/journal.pon } \\
\text { e.0151019 }\end{array}$ & $\begin{array}{l}\text { Avaliar o impacto das } \\
\text { deficiências de } \\
\text { micronutrientes na } \\
\text { incidência da malária e } \\
\text { vice-versa no estado } \\
\text { brasileiro do Amazonas. }\end{array}$ & $\begin{array}{l}\text { Um total de } 33(34,7 \%) \text { das crianças tinha malária prévia. A } \\
\text { estatura para idade foi registrada em } 42,1 \% \text {, a estatura para } \\
\text { idade em } 11,6 \% \text {, o IMC para a idade em } 17,9 \% \text { e IMC para idade } \\
\text { em } 3,2 \% \text { das crianças. A hemoglobina média foi de } 11,5 \mathrm{~g} \text { / e a } \\
\text { prevalência de anemia foi de } 57,4 \% \text {. } \\
\text { Foi observada a deficiência de vitamina A em } 35,9 \% \text {, } \\
\text { deficiência de betacaroteno em } 63,0 \% \text {, deficiência de zinco em } \\
60,9 \% \text { e deficiência de ferro em } 51,1 \% \text { nas crianças. } \\
\text { Um total de } 76 \text { ( } 80,0 \% \text { das crianças possuía mais de um } \\
\text { parasita intestinal. Ascaris lumbricoides foi comum em } 44,2 \% \\
\text { das crianças. }\end{array}$ \\
\hline 3 & $\begin{array}{l}\text { ALEXANDRE et } \\
\text { al., } \quad 2015 . \\
\text { DOI.org/10.13 } \\
\text { 71/journal.pnt } \\
\text { d.0003743 }\end{array}$ & $\begin{array}{l}\text { Avaliar a relação entre } \\
\text { malária e desnutrição em } \\
\text { crianças residentes em } \\
\text { uma comunidade rural da } \\
\text { Amazônia onde a malária } \\
\text { é endêmica. }\end{array}$ & $\begin{array}{l}\text { Foram acompanhadas } 202 \text { crianças, a maioria tinha entre } 5 \text { e } \\
10 \text { anos de idade. Uma minoria havia passado por episódios } \\
\text { anteriores de malária }(25,2 \%) \text {. } \\
\text { Hemoglobina abaixo de } 11,9 \mathrm{~g} / \mathrm{dL} \text { foi observada em } 110 \\
\text { crianças }(54,5 \%) \text { e o parasita helmíntico mais comum em } \\
\text { crianças foi Ascaris lumbricoides }(26,7 \%) \text {. } \\
\text { Durante o período de acompanhamento, } 87 \text { crianças }(43,1 \%) \\
\text { apresentaram pelo menos um episódio de malária. } \\
O \text { P. vivax predominou com } 119 \text { episódios }(72,6 \%) \text {. As crianças } \\
\text { que sofreram episódios de malária durante o acompanhamento } \\
\text { apresentaram piores valores de parâmetros antropométricos } \\
\text { nesse período. A principal mudança foi a redução da velocidade } \\
\text { de crescimento linear, associada ao número de episódios e à } \\
\text { proximidade do último ou único episódio da malária e da } \\
\text { segunda avaliação antropométrica. }\end{array}$ \\
\hline 4 & $\begin{array}{l}\text { MACEDO et al., } \\
2010 .\end{array}$ & $\begin{array}{l}\text { Avaliar o consumo } \\
\text { alimentar e nutricional de } \\
\text { escolares de } 5 \text { a } 15 \text { anos } \\
\text { de ambos os sexos, de } \\
\text { uma área endêmica de } \\
\text { malária do Amazonas. }\end{array}$ & $\begin{array}{l}\text { Foram avaliadas } 168 \text { crianças, sendo } 57 \% \text { do gênero masculino } \\
\text { e } 43 \% \text { feminino. No diagnóstico nutricional foi observado } 12 \% \\
\text { de desnutrição segundo parâmetros do IMC/I, quanto a E/I } \\
65 \% \text { das crianças apresentaram risco de baixa estatura e } 18 \% \\
\text { baixa estatura sendo estas infectadas duas vezes pelo parasita } \\
\text { da malária (p }=0,0308) \text {. } \\
\text { No consumo alimentar foi verificado um baixo consumo diário } \\
\text { de frutas e verduras principalmente de tucumã }(2,8 \%) \text {, mamão } \\
(0,5 \%) \text { e jerimum }(6,6 \%) \text { alimentos importantes no aumento } \\
\text { da imunidade devido serem fontes de vitamina A. }\end{array}$ \\
\hline 5 & $\begin{array}{l}\text { ALECRIM et al., } \\
2000 . \\
\text { DOI.org/10.15 } \\
90 / \text { S0037- } \\
868220000002 \\
00001\end{array}$ & $\begin{array}{l}\text { Avaliar o tratamento de } \\
\text { crianças com malária } \\
\text { falciparum e vivax com } \\
\text { artesunate retocaps } 囚 .\end{array}$ & $\begin{array}{l}\text { A anemia foi confirmada em } 31(96,8 \%) \text { crianças, sendo que } 14 \\
\text { apresentaram anemia grave com hematócrito abaixo de } 22 \% \text {. } \\
\text { Em } 59,3 \% \text { das crianças a anemia foi ocasionada pela malária. } \\
\text { A classificação da parasitemia nas crianças foi: } 21 \text { crianças com } \\
\text { baixa parasitemia, } 7 \text { com média parasitemia e } 1 \text { com alta } \\
\text { parasitemia. }\end{array}$ \\
\hline 6 & $\begin{array}{l}\text { NORONHA et } \\
\text { al., } \quad(2000) . \\
\text { DOI.org/10.15 } \\
90 / \text { cS0037- } \\
868220000002 \\
00005\end{array}$ & $\begin{array}{l}\text { Avaliar as } \text { características } \\
\text { clínicas da } \text { Malária } \\
\text { falciparum em crianças } \\
\text { procedentes da Amazônia } \\
\text { brasileira. }\end{array}$ & $\begin{array}{l}\text { Foram estudadas } 61 \text { crianças com malária falciparum, cuja } \\
\text { média de idade foi 7,5 anos, a idade mínima observada foi } 4 \\
\text { meses e a máxima } 14 \text { anos. } \\
\text { A anemia esteve associada aos maiores níveis de parasitemia. } \\
\text { Cinquenta e oito }(91,5 \%) \text { pacientes apresentaram malária não } \\
\text { complicada, } 3(4,9 \%) \text { malária grave e a letalidade foi } 1,6 \% \text {. }\end{array}$ \\
\hline
\end{tabular}


Tabela 1. Resultados de estudos sobre desempenho escolar de crianças e adolescentes acometidas por malária, na região amazônica, considerando os parâmetros: dados de

autoria, objetivos e resultados das pesquisas.

\begin{tabular}{|c|c|c|c|}
\hline No & Autor/Ano & Objetivos & Resultados \\
\hline 1 & $\begin{array}{l}\text { TAPAJÓS et al., } \\
2019 . \\
\text { DOI.org/10.1186 } \\
\text { /s12936-019- } \\
2802-2\end{array}$ & $\begin{array}{l}\text { Avaliar o impacto da } \\
\text { infecção por malária } \\
\text { na cognição de } \\
\text { crianças em uma } \\
\text { comunidade } \\
\text { periurbana na } \\
\text { Amazônia brasileira } \\
\text { com endemicidade } \\
\text { moderada por meio } \\
\text { da aplicação do } \\
\text { Inventário Doméstico } \\
\text { e do WPPSI-IV. }\end{array}$ & $\begin{array}{l}\text { Um total de } 219 \text { crianças com idades entre } 2 \text { e } 7 \text { anos } \\
\text { foram matriculadas. Embora } 205(95 \%) \text { crianças } \\
\text { tivessem peso normal ao nascer, } 177(81 \%) \text { estavam } \\
\text { desnutridas e } 35(16 \%) \text { tinham anemia. Entre as } 100 \\
(46 \%) \text { crianças que tiveram pelo menos um episódio } \\
\text { de malária, } 89(89 \%) \text { crianças demonstraram baixo } \\
\text { nível de desenvolvimento cognitivo. Os resultados } \\
\text { mostraram que a malária por } P \text {. vivax foi um fator de } \\
\text { risco independente para baixo desenvolvimento } \\
\text { cognitivo. }\end{array}$ \\
\hline 2 & $\begin{array}{l}\text { BRASIL et al., } \\
\text { 2017. } \\
\text { DOI.org/10.1186 } \\
\text { / s12936-017- } \\
2026-2\end{array}$ & $\begin{array}{l}\text { Investigar se o } \\
\text { histórico de malária } \\
\text { pode prejudicar as } \\
\text { habilidades verbais e } \\
\text { de desempenho de } \\
\text { crianças que vivem } \\
\text { em uma área } \\
\text { endêmica com baixa } \\
\text { transmissão da } \\
\text { malária por P. vivax. }\end{array}$ & $\begin{array}{l}\text { Um total de } 17 \text { casos e } 26 \text { controles foi incluído no } \\
\text { estudo. Observou-se baixa pontuação significativa do } \\
\text { quociente verbal nos casos }(\mathrm{p}=0,005) \text {, porém o QI de } \\
\text { desempenho foi semelhante nos dois grupos }(\mathrm{p}= \\
0,304) \text {. O QI em escala real foi significativamente } \\
\text { menor nos casos quando comparados aos controles } \\
\text { (p = 0,042). O índice fatorial apresentou diferença } \\
\text { significativa apenas no subteste de compreensão } \\
\text { verbal com os menores valores nos casos ( } \mathrm{p}= \\
0,0382) \text {, em relação aos controles. A organização } \\
\text { perceptual (p = 0,363), ausência de distração }(\mathrm{p}= \\
0,180) \text { e velocidade de processamento }(\mathrm{p}=0,132) \\
\text { foram semelhantes nos dois grupos. }\end{array}$ \\
\hline 3 & $\begin{array}{l}\text { VITOR-SILVA et } \\
\text { al., } \quad 2009 . \\
\text { DOI.org/10.1186 } \\
/ 1475-2875-8- \\
230\end{array}$ & $\begin{array}{l}\text { Determinar a relação } \\
\text { entre malária e } \\
\text { desempenho escolar } \\
\text { em crianças que } \\
\text { vivem em uma área } \\
\text { endêmica onde } P \text {. } \\
\text { vivax é a espécie } \\
\text { responsável pela } \\
\text { maioria dos casos. }\end{array}$ & $\begin{array}{l}\text { Foram analisados } 70 \text { alunos com malária. O P. vivax } \\
\text { foi detectado em } 69,2 \% \text { dos ataques, } P \text {. falciparum } \\
\text { em } 25 \% \text { e ambas as espécies em } 5,3 \% \text {. Na análise } \\
\text { multivariada, o ajuste por idade, escolaridade da mãe, } \\
\text { tempo vivendo na área de estudo e absenteísmo } \\
\text { escolar, apresentando com pelo menos um episódio } \\
\text { de malária previu independentemente um } \\
\text { desempenho ruim na escola [OR }=1,91(1,04-3,54) ; p \\
=0,039] \text {. }\end{array}$ \\
\hline
\end{tabular}

Fonte: dados dos autores

Os estudos analisados avaliaram o efeito da malária em crianças e adolescentes na região amazônica (Tabela 1 e 2). Das publicações encontradas, seis apresentaram dados relacionados à desnutrição, anemia e parasitose. Apenas três estudos avaliaram a inter-relação entre a malária, desnutrição e helmintos intestinais, que podem prejudicar o desenvolvimento cognitivo em crianças.

Na maioria dos estudos foi adotado as medidas antropométricas preconizadas pelo Ministério da Saúde do Brasil por meio do Sistema de Vigilância Alimentar e Nutricional (SISVAN, 2006), juntamente com os parâmetros: escores z-E/I e IMC/Idade, para diagnóstico nutricional. Alexandre et al., (2015) avaliaram o estado nutricional de crianças com malária, através de medições antropométricas e concentração de hemoglobina em 202 crianças de 1 mês a 14 anos de idade por um ano. Os resultados mostraram o comprometimento nutricional de crianças com malária, onde houve redução da velocidade de crescimento linear. 
Na América Latina, a incidência de anemia grave é significativamente menor do que a relatada na África ou na Ásia (QUINTERO et al., 2011). Porém, alguns fatores devem ser levados em consideração, como alterações hematológicas específicas associadas à infecção por malária, que podem variar com o nível de endemicidade (IDRO et al., 2006); estado nutricional (FRIEDMAN et al. 2005); fatores demográficos (BARCUS et al., 2007); imunidade a malária (LANGHORNE et al., 2008) e; as espécies de parasitas.

Os resultados de Noronha et al., (2000) apontam para a importância da anemia nas crianças menores de cinco anos com malária falciparum atendidas no Instituto de Medicina Tropical-AM, sugerindo a necessidade da monitorização do nível de hemoglobina, a fim de diminuir a morbidade pela doença, uma vez que 58 (91,5\%) dos pacientes apresentaram malária não complicada, três $(4,9 \%)$ apresentaram malária grave e a letalidade foi 1,6\%. Outro estudo mostrou que a maioria das crianças em idade escolar nas áreas rurais amazônicas eram anêmicas, podendo ter várias causas (FERREIRA et al. 2007).

Melo et al. (2010) observaram que em crianças com ausência de helmintos intestinais, houve uma diminuição significativa da hemoglobina durante o ataque de malária em comparação com a concentração basal. Os achados de Alecrim et al., (2000) apontaram uma resposta clínica e parasitológica com Artesunate Retocaps® em 32 crianças com malária. Os resultados mostraram que as crianças apresentaram melhora clínica no segundo dia de tratamento e se mostrou eficiente em negativar a parasitemia nas crianças, independente da gravidade do estado clínico.

Estudos indicam que crianças desnutridas com altos níveis de exposição a doenças parasitárias (KVALSVIG et al., 1991), com baixo nível socioeconômico (HOFF, 2003), nascidas de mães jovens sem escolaridade (ALI et al., 2013), são propensas ao baixo desempenho em testes cognitivos e linguagem. Vitor-Silva et al., (2009) estudaram crianças de uma zona rural do estado do Amazonas onde predomina a infecção por $P$. vivax, os autores mostraram que a ocorrência de pelo menos um episódio de malária ao longo do ano letivo estava associado ao baixo desempenho escolar nas disciplinas de português e matemática.

Por fim, Tapajós et al. (2019) associaram o baixo desenvolvimento cognitivo em crianças à infecção por malária, por meio de uma pesquisa com 219 crianças residentes em uma área periurbana de Manaus. 0 estudo apresentou alta proporção de crianças com baixo desenvolvimento cognitivo vivendo em condições precárias de saneamento, baixo estímulo materno e familiar para aprendizagem, com alta exposição à malária. Além disso, crianças com histórico de malária por $P$. vivax apresentaram um comprometimento significativo dos quocientes verbais e de escala total, bem como um índice baixo significativo de compreensão verbal, associados provavelmente ao absenteísmo causado pela malária e à baixa escolaridade dos pais, o que dificulta uma resposta adequada aos estímulos ambientais (BRASIL et al., 2016).

\section{CONCLUSÃO}

A Amazônia brasileira é caracteristicamente uma área de transmissão instável de malária. Neste contexto epidemiológico, que difere, por exemplo, da situação africana, a transmissão de malária restringe-se em geral às bordas das florestas, sendo menos intensa em povoados e cidades. Os resultados descritos no presente artigo são raros, alguns são pioneiros, e é sabido da importância da temática para a saúde pública, por 
isso mais estudos são necessários para o esclarecimento sobre a associação da malária com a deficiência do estado nutricional e com o comprometimento do rendimento escolar de crianças em outras áreas endêmicas por P. vivax e P. falciparum na Amazônia.

\section{AGRADECIMENTOS}

Agradecemos à Coordenação de Apoio à Formação de Pessoal de Nível Superior (CAPES) e ao Conselho Nacional de Desenvolvimento Científico e Tecnológico (CNPq) pela bolsa de fomento.

\section{REFERÊNCIAS}

ALEXANDRE, M. A. A.; BENZECRY, S.G.; SIQUEIRA, A.M.; VITOR-SILVA, S.; MELO, G. C.; MONTEIRO, W. M.; LEITE, H. P.; LACERDA, M. G. V.; ALECRIM, M. G. C. The Association between Nutritional Status and Malaria in Children from a Rural Community in the Amazonian Region: A Longitudinal Study. PloS Negl Trop Dis 9 (4): e0003743. 2015.

ALECRIM, M.G.C.; CARVALHO, L.M.; FERNANDES, M.C.; ANDRADE, S.D.; LOUREIRO, A.C.; ARCANJO, A.R.L.; ALECRIM, W.D. Malaria treatment with artesunate (retocaps $($ ) in children of the Brazilian Amazon. Rev Soc Bras Med Trop. 33 (2): 163-168. 2000.

ALENCAR, F.H.; YUYAMA, L.K.O.; GUTIERREZ, M.E.L. Estado nutricional e alimentar de indivíduos com residentes da malária no Amazonas Estado-Brasil. Acta Amazônica. 31: 227-236. 2001.

ALI, N. S.; MAHMUD, S.; KHAN, A.; ALI, B. S. Impact of postpartum anxiety and depression on child's mental development from two peri-urban communities of Karachi, Pakistan: a quasi-experimental study. BMC Psychiatry. 13:274. 2013.

BENZECRY, S. G.; ALEXANDRE, M. A.; VÍTOR-SILVA, S.; SALINAS, J. L.; DE MELO, G. C.; MARINHO, H. A.; PAES, A. T.; SIQUEIRA, A.M.; MONTEIRO, W. M.; LACERDA, M. G. V.; LEITE, H. P. Micronutrient Deficiencies and Plasmodium vivax Malaria among Children in the Brazilian Amazon. PLoS ONE 11(3): e0151019. 2016. doi:10.1371/journal. pone.0151019.

BERKMAN, D. S.; LESCANO, A. G.; GILMAN, R. H.; LOPEZ, S. L.; BLACK, M. M. Effects of stunting, diarrhoeal disease, and parasitic infection during infancy on cognition in late childhood: a follow-up study. Lancet. 359: 564-571. 2002.

BOIVIN, M. J.; BANGIRANA, P.; BYARUGABA, J.; OPOKA, R. O.; IDRO, R.; JUREK A. M.; JOHN, C. C. Cognitive impairment after cerebral malaria in children: a prospective study. Pediatrics. 119: e360-6. 2007.

BOIVIN, M.; POULIN, F.; VITARO, F. Depressed mood and peer rejection in childhood. Development and Psychopathology. 6: 483-498. 2002.

CARDOSO, M. A.; FERREIRA, U. M.; CAMARGO, L. M. A.; SZARFARC, S. C. Anemia em população de área endêmica de malária, Rondônia (Brasil). Rev Saude Publica, São Paulo. 26: 161-166. 1992. 
CARTER, J. A.; MUNG'ALA-ODERA, V.; NEVILLE, B. G.; MURIRA, G.; MTURI, N.; MUSUMBA, C.; NEWTON, C. R. J. C. Persistent neurocognitive impairments associated with severe falciparum malaria in Kenyan children. J Neurol Neurosurg Psychiatry. 76 (4): 476-81. 2005.

CARSWELL, F.; HUGHES, A. O.; PALMER, R. I.; HIGGINSON, J.; HARLAND, P. S.; MEAKINS, R. H. Nutritional status, globulin titers, and parasitic infections of two populations of Tanzanian school children. Am J Clin Nutr. 34: 1292-1299. 1981.

CAULFIELD, L. E.; RICHARD, S. A.; BLACK, R. E. Undernutrition as an underlying cause of malaria morbidity and mortality in children less than five years old. Am. J. Trop. Med. Hyg. 71(2): 55-63. 2004.

CUSTODIO, E.; DESCALZO, M. A.; VILLAMOS, E.; MOLINA, L.; SANCHEZ, I.; LWANGA, M.; BERNIS, C.; BENITO, A.; ROCHE, J. Nutritional and socio-economic factors associated with Plasmodium falciparum infection in children from Equatorial Guinea: results from a nationally representative survey. Malar J. 8: 225. 2009.

FERNANDO, S. D.; GUNAWARDENA, D. M.; BANDARA, M. R. S. S.; DE SILVA, D.; CARTER, R.; MENDIS, K. N.; WICKREMASINGHE, A. R. The impact of repeated malaria attacks on the school performance of children. Am J Trop Med Hyg. 69: 582-8. 2003.

FERREIRA, J. O.; LACERDA, M. V.; BRASIL, P.; LADISLAU, J.L.; TAUIL, P. L.; DANIELRIBEIRO, C. T. Malaria in Brazil: an overview. Malar J. 9:115. 2010.

FERREIRA, M. U.; SILVA-NUNES, M.; BERTOLINO, C. N.; MALAFRONTE, R. S.; MUNIZ, P. T.; CARDOSO, M. A. Anemia and iron deficiency in school children, adolescents, and adults: a community-based study in rural Amazonia. Am J Public Health. 97 (2): 237-239. 2007.

FILLOL, F.; COURNIL, A.; BOULANGER, D.; CISSE, B.; SOKHNA, C.; TARGETT, G.; TRAPE, J.F.; SIMONDON, F.; GREENWOOD, B.; SIMONDON, K. B. Influence of wasting and stunting at the onset of the rainy season on subsequent malaria morbidity among rural preschool children in Senegal. Am J Trop Med Hyg. 80: 202-208. 2009.

GENTON, B.; Al-YAMAN, F.; GINNY, M.; TARAIKA, J.; AIPERS, M. P. Relation of anthropometry to malaria morbidity and immunity in Papua New Guinean children. Am J Clin Nutrition. 68: 734-741. 1998.

HOFF, E. The Specificity of Environmental Influence: Socioeconomic Status Affects Early Vocabulary Development Via Maternal Speech. Child Dev. 74: 1368-78. 2003.

IDRO, R.; KAKOOZA-MWESIGE, A.; BALYEJJUSSA, S.; MIREMBE, G.; MUGASHA, C.; TUGUMISIRIZE, J.; BYARUGABA. J. Severe neurological sequelae and behaviour problems after cerebral malaria in Ugandan children. BMC Res Notes. 3: 104. 2010.

KVALSVIG, J. D.; COOPPAN, R. M.; CONNOLLY, K. J. The effects of parasitic diseases on cognitive processes in children. Ann Trop Med Parasitol. 85: 551-68. 1991.

KIHARA, M.; CARTER, J. A.; NEWTON, C. R. The effect of Plasmodium falciparum on cognition: a systematic review. Trop Med Int Health. 11: 386-397. 2006. 
LADEIA-ANDRADE, S.; FERREIRA, M. U.; DE CARVALHO, M. E.; CURADO, I.; COURA, J.R. Age-dependent acquisition of protective immunity to malaria in riverine populations of the Amazon Basin of Brazil. Am J Trop Med Hyg. 80:452-9. 2009.

LALLOO, D. G.; OLUKOYA, P.; OLLIARO, P. Malaria in adolescence: burden of disease, consequences, and opportunities for intervention. Lancet Infect Dis. 6: 780-793. 2006.

LANCA, E. F.; MAGALHAES, B. M.; VITOR-SILVA, S.; SIQUEIRA, A. M.; BENZECRY, S. G.; ALEXANDRE, M. A. A.; O'BRIEN, C.; BASSAT, Q.; LACERDA, M. G. V. Risk factors and characterization of Plasmodium vivax-associated admissions to pediatric intensive care units in the Brazilian Amazon. PLoS ONE. 7: e35406. 2012.

MACEDO, R. S.; ARAÚJO, L. G. B.; ESTRÁZULAS, J. A.; LIBERALI, R.; BENZECRY, S. G.; LACERDA, M. V. G. Avaliação de consumo alimentar e nutricional de escolares de 5 a 15 anos de uma área endêmica de malária do Amazonas. Revista digital. Buenos Aires. 14: 142. 2010.

MARQUES, A.; GUTIERREZ, H.C. Combate à malária no Brasil: evolução, situação atual e perspectivas. Rev Soc Bras Med Trop. 27: 91-108. 1994.

MEREMIKWU, M. M.; ASINDI, A. A.; EZEDINACHI, E. The pattern of neurological sequelae of childhood cerebral malaria among survivors in Calabar, Nigeria. Cent Afr J Med. 43: 231-234. 1997.

MORGONO, S.; BIDASARI, L.; SYAHRIL, P.; HENDRI, W.; AYODHIA, P. P. The correlation between platelet count and parasite density in children with malaria infection. Asian Pac J Trop Dis. 6 (30: 199-203. 2016.

MURPHY, S. C.; BREMAN, J. G. Gaps in the childhood malaria burden in africa: cerebral malaria, neurological sequelae, anemia, respiratory distress, hypoglycemia, and complications of pregnancy. Am J Trop Med Hyg. 64: 57-67. 2001.

NORONHA, E.; ALECRIM, M.G.C.; ROMERO, G.A.S.; MACEDO, V. Estudo clínico da malária falciparum em crianças em Manaus, AM, Brasil. Rev Soc Bras Med Trop. 33 (2): 185-190. 2000.

OMS. Ministério Da Saúde (Brasil). Situação Epidemiológica da Malária no Brasil de 2000 a 2001. Boletim Epidemiológico. 44 (1): 1-16. 2013.

OPAS. Organização Pan-Americana da Saúde. https://www.paho.org/bra/index.php?option=com_content\&view=article\&id=5287:mal aria-2\&Itemid=875. Acesso em 05/02/2021

SNOW, R. W.; BYASS, P.; SHEHNTON, F.C.; GREENWOOD, B.M. The relationship between anthropometric measurements and measurements of iron status and susceptibility to malaria in Gambian children. Trans R Soc Trop Med Hyg. 85 (5): 584-9. 1991.

SHANKAR, A. H. Nutritional modulation of malaria morbidity and mortality. J Infect Dis 182 (1): S37-S53. 2000. 
SCRIMSHAW, N. S.; SANGIOVANNI, J. P. Synergism of nutrition, infection, and immunity: an overview. Am J Clin Nutr. 66: 464S-477S. 1997.

VENTURA, A. M.; PINTO, A. Y.; SILVA, R. S.; CALVOSA, V. S.; SILVA-FILHO, M. G.; SOUZA, J.M. Malária por Plasmodium vivax em crianças e adolescentes: aspectos epidemiológicos, clínicos e laboratoriais. J Pediatr, Rio de Janeiro. 75 (3): 187-194.1999.

VITOR-SILVA, S.; REYES-LECCA, R.C.; PINHEIRO, T. R. A.; LACERDA, M. V. G. Malaria is associated with poor school performance in an endemic area of the Brazilian Amazon. Malar J. 8: 230. 2009.

WHO. World Malaria Report Geneva. 2012.

WHO. Relatório Mundial da Malária 2019. Genebra, Organização Mundial da Saúde, 2019 


\section{Capítulo 11}

\section{Avaliação do estado nutricional de uma frequentadora de acadêmica de atividade funcional: Relato de caso.}

\section{Marli Mendonça Pereira}

Francimeire Gomes Pinheiro

\section{Resumo:}

O climatério corresponde à fase da vida da mulher em que ocorre a transição do período reprodutivo para o não reprodutivo. Diante disto, o objetivo do trabalho foi avaliar o estado nutricional de uma frequentadora de atividade funcional. 0 estudo foi um relato de caso, o qual foi realizado em uma academia localizada na zona centro-sul do município de Manaus, a coleta dos dados deu-se no período de setembro de 2017 a agosto de 2018. Os dados foram obtidos da ficha de informação da frequentadora, a qual se encontrava no período do climatério. Na ficha encontravam-se as seguintes variáveis, a saber: conhecimento sobre a alimentação; avaliação antropométrica (peso, altura e circunferência da cintura). Os resultados obtidos foram: a média de peso foi $66,8 \mathrm{Kg}$; IMC 26,7; Relação Cintura/Quadril (RCQ) 0,81 e o \% de gordura corporal com 43,1. Em relação ao consumo alimentar, dos grupos de alimentos com maior frequência na alimentação da frequentadora foi: grupo do arroz; óleos e gorduras; açúcares e doces; leite e seus derivados e por último o das carnes e ovos. Mulheres no climatério sofrem com as alterações hormonais, isto poderia estar relacionado às modificações na distribuição de massa gordurosa, principalmente na região abdominal, uma vez que está diretamente ligada ao desenvolvimento de doenças crônicas não transmissíveis, entre elas a diabete, a resistência à insulina e as doenças cardiovasculares. É evidenciado que prevalência de sobrepeso associada com a piora da qualidade de vida reforça a necessidade de uma intervenção nutricional para correção do perfil antropométrico, e consequente benefícios para a saúde da frequentadora nesta fase do climatério.

Palavras-chave: Avaliação antropométrica; saúde da mulher; hábitos alimentares. 


\section{INTRODUCĈ̃O}

A mulher da menarca à menopausa passa por um conjunto de processos que afetam seu funcionamento sexual, que são as mudanças hormonais e fisiológicas tanto no início dos ciclos menstruais na puberdade quanto no final desses ciclos no climatério (BOUZAS; BRAGA e LEÃO, 2010).

A área da saúde da mulher vem explorando o período do climatério, principalmente por esse ocorre em plena vida produtiva do indivíduo. Esse momento representa a transição paulatina da fase reprodutiva e não reprodutiva da mulher (HOFFMAN et al., 2015). Alguns autores afirmam que o climatério inicia-se por volta dos 35 e terminando aos 65 anos, outros apontam a idade dos 40 para esse início (SANTOS et al., 2008; GALLON, 2009; GALLON e WENDER, 2012).

O climatério atinge as mulheres causando-lhes sinais e sintomas que trazem desconfortos em menor ou maior grau, variando de mulher para mulher (LORENZI et al., 2009). A sintomatologia típica do período do climatério incluem fogachos, insônia, irritabilidade, depressão, sudorese, palpitação, cefaléia, esquecimento, problemas urinários, estresse, além de transtornos como: desajustes conjugais, problemas familiares; e também alterações na sexualidade, dentre outros (OLIVEIRA; JESUS; MERIGHI, 2008; PITOMBEIRA et al., 2011)

De acordo com Pereira; Lima (2015) e Coelho; Porto (2009), várias mudanças biológicas são observadas no período do climatério, como, endócrinas (alterações hormonais); metabolismo ósseo (osteoporose); metabolismo lipídico (aumento da lipoproteína de baixa densidade e diminuição da de alta densidade). Um fator predominante e a substituição da musculatura por tecido adiposo, fato esse observado com a mudança da alimentação dessas mulheres.

A ingestão de uma alimentação equilibrada é fundamental para promover a saúde da mulher climatérica, uma vez que o consumo alimentar inadequado constitui-se como um importante fator de risco para o desenvolvimento de doenças altamente prevalentes nessa fase da vida (TARDIVO, 2008; SILVA, 2010).

Como neste período o crescimento e o desenvolvimento orgânico já se efetivaram, torna-se fundamental uma alimentação saudável assim como a manutenção do peso adequado, evitando-se a obesidade que além de ser uma doença crônica, aumenta o risco do desenvolvimento de outras doenças crônicas como a diabete mellitus, hipertensão arterial, dentre outras comorbidades (PEREIRA et al., 2014).

Os hábitos alimentares são imprescindíveis para proporcionar qualidade na saúde da mulher no período climatérico, o conhecimento desses hábitos pode auxiliar na construção de uma dieta mais rica em produtos necessários nessa fase, em particular para as mulheres amazônicas, no qual o consumo de produtos ricos em carboidratos é assustador. Diante da problemática, o objetivo do trabalho foi avaliar o estado nutricional de uma frequentadora de atividade funcional.

\section{REFERENCIAL TEÓRICO}

\subsection{CONTEXTULIZANDO SOBRE O CLIMATÉRIO}

O climatério é o período em que a mulher avalia e redescobri o próprio corpo, devido as alterações sofrida por ela, alguns autores afirmam que pode ser definida como a fase da vida da mulher na qual ocorre a transição do período reprodutivo para o não 
reprodutivo, tendo início próximo aos 40 anos e encerrando-se aos 65 (GALVÃO et al., 2007; POLISSENI et al., 2008). É nesse espaço de tempo em que ocorre a menopausa. Geralmente, considera-se que ela ocorra 12 meses após o último ciclo menstrual (BISOGNIN et al., 2015).

A origem do termo climatério vem do grego Klimáter, temos o significado de "período crítico da vida" (MENDONÇA, 2004). Em termos biológico, a menopausa, ou fim das menstruações espontâneas, é um processo biológico natural, que ocorre na vida da mulher: com o envelhecimento, ocorre uma alteração na estrutura e função dos folículos ovários (FILHO et al., 2015). Já para Wu et al., (2014) é a interrupção permanente da menstruação. Pode ocorrer naturalmente ou de forma artificial, após procedimentos clínicos ou cirúrgicos que levem à parada da produção hormonal ovariana.

\subsection{A EPIDEMIOLOGIA DO CLIMATÉRIO}

Dados do Censo 2010 do Instituto Brasileiro de Geografia e Estatística (IBGE) confirma que a população feminina brasileira totaliza mais de 98 milhões de mulheres. Nesse universo, cerca de 30 milhões têm entre 35 e 65 anos, o que significa que $32 \%$ das mulheres no Brasil estão na faixa etária em que ocorre o climatério (IBGE, 2010).

O Ministério da Saúde (MS) propôs dividir o período do climatério em: prémenopausa, iniciando-se geralmente após os 40 anos, com diminuição da fertilidade em mulheres com ciclos menstruais regulares ou com padrão menstrual similar ao ocorrido durante a vida reprodutiva; perimenopausa iniciando-se dois anos antes da última menstruação e vai até um ano após (com ciclos irregulares e alterações endócrinas); pós-menopausa, começa um ano após o último período menstrual (BRASIL, 2008).

Para os autores Pedro et al., (2002) e Pedro et al. (2003), atualmente, existem poucos estudos de base populacional, nacionais ou latino-americanos, sobre a epidemiologia do climatério e da menopausa. A maioria dos dados disponíveis origina-se de países desenvolvidos da América do Norte e Europa. No Brasil, foi realizado um inquérito de base populacional com mulheres climatéricas na cidade de Campinas (SP) há mais de 15 anos.

\section{MATERIAL E MÉTODOS}

\subsection{TIPO DE ESTUDO}

O estudo foi um relato de caso, o qual tem como fundamento segundo Gil, (2016) a pesquisa sobre determinado indivíduo, família, grupo ou comunidade que seja representativo de seu universo, a fim de se examinarem aspectos variados relacionados à sua vida. A pesquisa é realizada a partir das informações referentes a um caso do qual o pesquisador não faz parte, ou seja, não se trata da experiência ou da vivência profissional do pesquisador.

\subsection{LOCAL DE ESTUDO E PERÍODO DE COLETA}

0 estudo foi realizado em uma academia de atividades funcionais, localizada na zona centro-sul do município de Manaus, a coleta dos dados deu-se no período de setembro de 2017 a agosto de 2018 (figura 1). 
Figura 1 - Mapa de Manaus localizando as zonas da cidade com ênfase para zona centrosul onde localiza a academia.

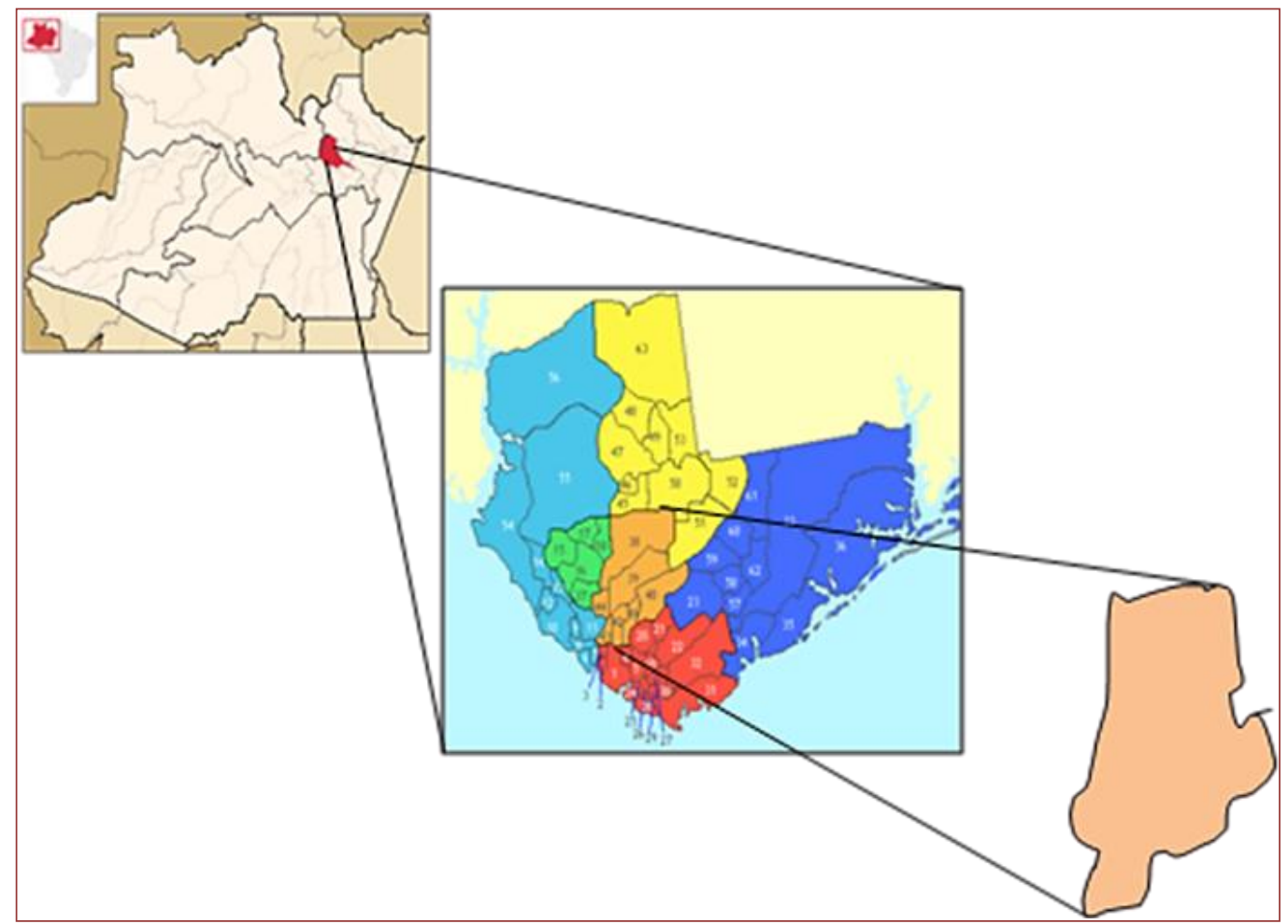

Fonte: Bairros de Manaus.

\subsection{COLETA DOS DADOS}

Para execução da coleta foi recebido autorização da instituição para compilação dos dados (Anexo), os quais foram obtidos da ficha de informação de uma frequentadora da academia, a qual se encontrava no período do climatério. Na ficha encontravam-se as seguintes variáveis, à saber: conhecimento sobre a alimentação; avaliação antropométrica (peso altura, circunferência da cintura e bioimpedância), para aferir o peso foi utilizada balança mecânica de plataforma Welmy®, com capacidade para 150 $\mathrm{kg}$, estatura foi aferida com estadiômetro acoplado à balança, com os voluntários descalços, a cabeça posicionada na posição de Frankfurt, ou seja, com olhar para o horizonte, os braços estendidos ao longo do corpo e sem adereços de acordo com Cuppari (2005). A circunferência da cintura foi medida com fita graduada inelástica, segundo Després et al. (2001), sendo considerado risco muito aumentado para doença cardiovascular quando $\geq 88 \mathrm{~cm}$, segundo classificação da National Cholesterol Education Program (NCEP, 2005).

\subsection{ANÁLISE DOS DADOS}

Para a classificação do IMC (Índice de Massa Corpórea), foram utilizados os limites recomendados pela Organização Mundial de Saúde (OMS, 1995), sendo eutrofia entre 18,5 e $24,99 \mathrm{~kg} / \mathrm{m}^{2}$. O percentual de gordura foi realizado por meio da bioimpedância elétrica bipolar modelo FE-068 TechLine $\AA$, na qual foi verificada a massa magra corporal e massa gorda. A classificação foi feita de acordo com Lohman (1992), com média normal de $23 \%$ gordura corporal e um risco de doenças associadas à obesidade quando a gordura corporal ultrapassar $32 \%$. 


\section{RESULTADOS E DISCUSSÃO}

O ciclo vital da mulher é constituído por três períodos críticos de transição: a adolescência, a gravidez e o climatério, São períodos biologicamente determinados, caracterizados por mudanças metabólicas complexas.

No período de setembro 2017 a agosto de 2018 foi realizado o fracionamento da composição corporal de uma frequentadora de treino funcional, a qual estava no período do climatério com idade de 51 anos, a qual apresentou os seguintes resultados: média de peso foi 66,8Kg; IMC 26,8; Relação Cintura/Quadril (RCQ) 0,81 e o \% de gordura corporal com 43,1 (tabela 1 ).

Tabela 1 - Fracionamento da composição corporal de uma frequentadora de treino funcional no período de 2017-2018.

\begin{tabular}{|l|c|c|c|c|}
\hline \multicolumn{1}{|c}{ Meses } & Peso Kg & IMC & RCQ & \% de Gordura corporal \\
\hline Setembro e Outubro & 65,8 & 26,4 & 0,78 & 42,8 \\
\hline Novembro e Dezembro & 65,7 & 26,3 & 0,78 & 42,5 \\
\hline Janeiro e fevereiro & 66,5 & 26,6 & 0,9 & 43,2 \\
\hline Março e Abril & 68 & 27,2 & 0,78 & 44,2 \\
\hline Maio e Junho & 68,5 & 27,4 & 0,78 & 44, \\
\hline Julho e agosto & 66,5 & 26,6 & 0,82 & 41,2 \\
\hline Média & 66,8 & 26,7 & 0,81 & 43,1 \\
\hline
\end{tabular}

Legenda: $\mathrm{IMC}=$ Índice de Massa corpórea; RCQ= Relação cintura quadril. Fonte: Passos Fitiness, 2018.

Para Lisboa; Cruz (2009), no climatério as mulheres podem apresentar um ganho de peso de até $0,8 \mathrm{Kg} / \mathrm{ano}$. No entanto, este ganho não pode ser atribuído somente à falta estrogênica, mas também ao maior consumo de alimentos energéticos, falta de atividade física e diminuição do metabolismo e das necessidades energéticas.

0 resultado do IMC neste estudo demonstrou que a referida encontrava-se com sobrepeso. De acordo com Martinazzo et al., (2013); David et al. (2013), o sobrepeso e a obesidade são fatores de risco relevantes no desenvolvimento de doenças crônicas não transmissíveis (DCNT), tais como, doenças do aparelho circulatório, diabetes mellitus, hipertensão arterial sistêmica e cânceres. Estes são responsáveis por produzirem mudanças metabólicas, tais como elevação do colesterol, triglicérides, com consequente aumento da pressão arterial e surgimento da resistência periférica à insulina.

Estudo sobre avaliação antropométrica de mulheres no climatério foi realizado por Gallon (2009), no qual foram avaliadas 200 pacientes climatéricas entre 40 e 65 anos de idade, e o resultado médio foi de 30,1 Kg/m2. Já Silva et al., (2010) avaliou 30 mulheres que estavam na menopausa, e em $83,3 \%$ da população apresentou IMC inadequado, com sobrepeso e obesidade.

Já o resultado da média da RCQ neste estudo foi de 0,81, o que apresenta baixo risco para desenvolver doenças cardiovasculares (DCV), mas nos meses de janeiro e fevereiro verificou-se que o RCQ foi de 0,9 , o qual indica o alto risco de desenvolver diabetes tipo 2, hipertensão ou angina. 
Mulheres no climatério sofrem com as alterações hormonais, isto poderia estar relacionado às modificações na distribuição de massa gordurosa, principalmente na região abdominal, uma vez que está diretamente ligada ao desenvolvimento de DCNT, entre elas a diabete, a resistência à insulina e as DCV (SBC, 2018). A média da RCQ do presente estudo foi inferior ao observado no estudo realizado por França (2003), que encontrou média de RCQ de 0,90 em uma população de 157 mulheres na pósmenopausa, na qual a maioria $(73,8 \%)$ apresentou obesidade abdominal.

Em relação à avaliação do consumo alimentar da frequentadora, não ocorreu como é recomendado na literatura, o qual utiliza métodos para esse arquissão, a saber: recordatório de 24 horas (R24h) e Questionário de Frequência Alimentar (QFA) (FISBERG; MARCHIONI; COLUCCI, 2009), entre outros. O R24h consiste na quantificação das preparações e alimentos ingeridos durante o dia anterior. O QFA constitui uma lista de alimentos, no qual o individuo registra sua ingestão usual e sua frequência por dia. Essa ausência de resultado mais preciso foi decorrente que na ficha da frequentadora, somente mencionava quantas vezes por semana ela ingeria os grupos pertinentes à pirâmide alimentar (PHILIPPI, 2013). Os alimentos pertinentes à pirâmide estão apresentados na figura 2.

Figura 2 - Distribuição de alimentos pela pirâmide alimentar atualizada

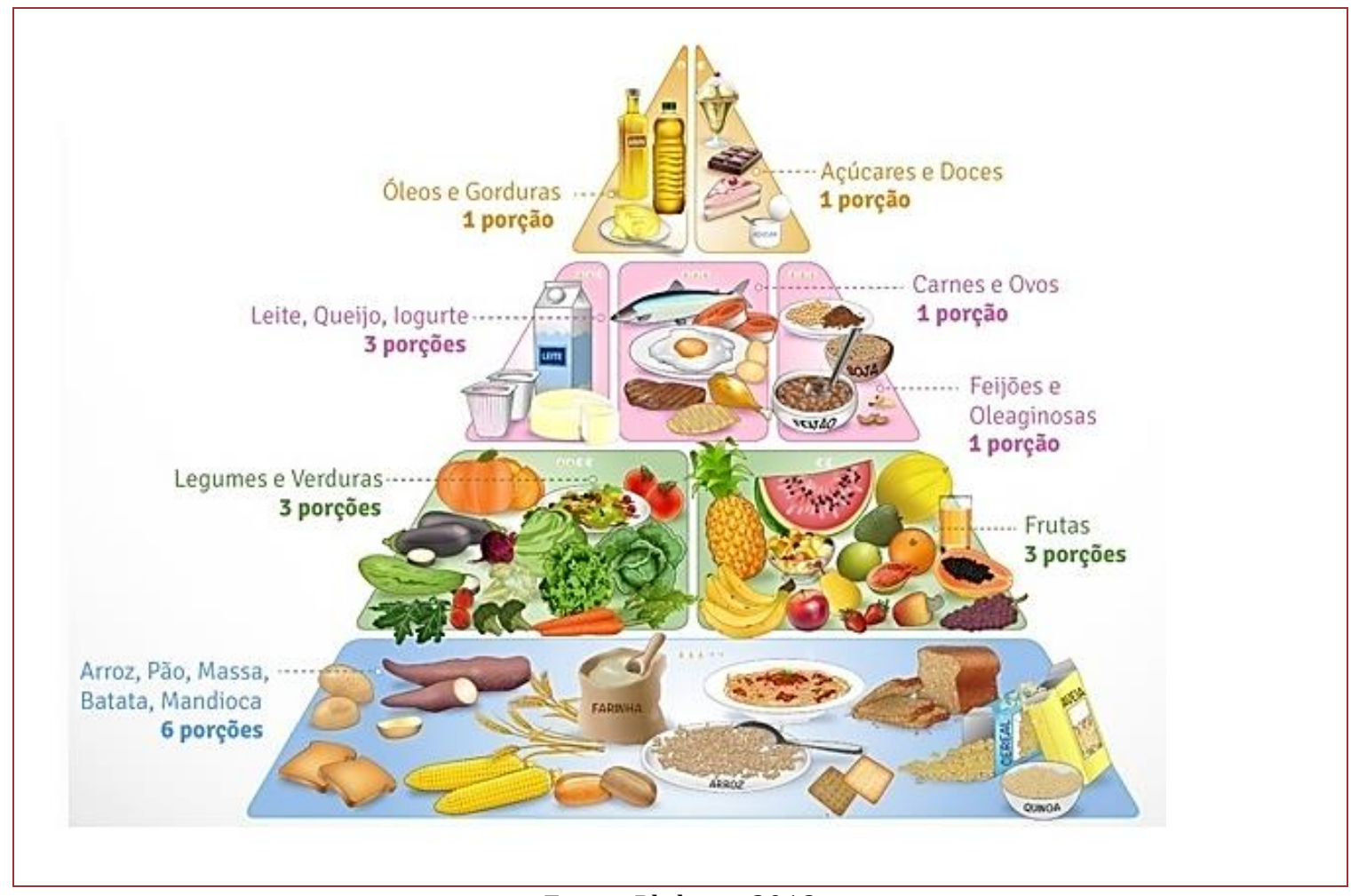

Fonte: Philippi, 2013

Dos grupos de alimentos com maior frequência na alimentação da frequentadora foram: grupo do arroz; óleos e gorduras; açúcares e doces; leite e seus derivados e por último o das carnes e ovos (tabela 2). 
Tabela 2 - Frequência alimentar dos grupos de alimentos

\begin{tabular}{|l|c|}
\multicolumn{1}{|c|}{ GRUPO DOS ALIMENTOS } & FREQUÊNCIA POR SEMANA \\
\hline Arroz, batata, mandioca, pães e massas & Seis vezes \\
\hline Frutas & Duas vezes \\
\hline Legumes e verduras & Três vezes \\
\hline Leite, queijos e iogurtes & Quatro vezes \\
\hline Carnes e ovos & Quatro vezes \\
\hline Feijões e oleaginosas & Três vezes \\
\hline Óleos e gorduras & Cinco vezes \\
\hline Açúcares e doces & Cinco vezes \\
\hline
\end{tabular}

Diante dos resultados podemos observar que a alimentação da frequentadora apresentava as seguintes características: a maior frequência para os carboidratos, de acordo com Philippi (2013), esse grupo pode ser consumido em maiores quantidades durante o dia; Um fato preocupante na dieta foi o consumo do grupo dos doces e açucares e óleos e gorduras, segundo o autor supracitado, alimentos dessa faixa devem ser consumidos com moderação, pois além de calóricos, podem aumentar os riscos de obesidade, doenças cardiovasculares, diabetes e outras enfermidades.

Vários agravos à saúde constatados no climatério relacionam-se na maioria das vezes direta ou indiretamente com a ingestão inadequada de alimentos, quer seja em excesso ou deficiência por longos períodos; essa inadequação, por sua vez, constitui importante fator de risco para inúmeras doenças, tais como as cardiovasculares, a obesidade, osteoporose, câncer de cólon e de mama (NESIL; CORRADINI, FELÍCIO, 2008; ORSATTI, 2008). Outras pesquisas relacionadas ao estado nutricional de mulheres no período do climatério demonstram que estas se alimentam de forma incorreta, ocasionando uma significativa prevalência de sobrepeso e obesidade nesta população (NOSER; MOREIRA; ANDRADE, 2009).

Alguns estudos também constatam a deficiência de micronutrientes, como as vitaminas A e C, e os minerais cálcio e ferro (SILVA; CABRAL; VASCONCELOS, 2010; LEÃO; SANTOS, 2012). Além disso, revelam importantes inadequações em relação ao consumo balanceado dos macronutrientes, e também em relação à ingestão hídrica recomendada, comprometendo assim, a manutenção da saúde da mulher principalmente nesta fase crítica da vida, que é o climatério (MARTINAZZO, 2013; ALMEIDA et al., 2015).

\section{CONCLUSÃO}

Diante dos resultados antropométricos podemos concluir que a frequentadora encontrava-se com sobrepeso, porém não somente pelas alterações hormonais decorrente do período do climatério, mas em particular por sua alimentação muito rica nos óleos e gorduras; açúcares e doces; leite e seus derivados.

É evidenciado que prevalência de sobrepeso associada com a piora da qualidade de vida reforça a necessidade de uma intervenção nutricional para correção do perfil antropométrico, e consequente benefícios para a saúde da frequentadora nesta fase do climatério. 


\section{REFERÊNCIAS}

ALMEIDA, A.; A.; FRANZ, L.; B.; B.; FREITAS, M.; T.; IDALÊNCIO, V.; H. A importância da alimentação saudável no período do climatério. In XXIII Seminário de Iniciação Científica. Universidade UNIJUI. 2105.

BRASIL, Ministério da Saúde (BR). Manual de Atenção à Mulher no Climatério/Menopausa. Brasília (DF): Ministério da Saúde; 2008a.

Instituto Brasileiro de Geografia e Estatística [site de Internet]. Censo Demográfico 2010. Características da população e dos domicílios: Resultados do universo. Acesso em 18 de julho de 2018.

BOUZAS, I.; BRAGA, C.; LEÃO, L. Ciclo menstrual na adolescência. Adolesc Saude. v.7, n. 3, p. 59-63. 2010.

COELHO, S.; PORTO, Y.; F. Saúde da Mulher. Nescon UFMG, 2009.

CUPPARI, L. Nutrição: nutrição clínica no adulto. 2. ed. Barueri, SP: Manole, 2005.

DAVID, H.; R.; MIRANDA, M.; P.; OLIVEIRA, F.; M.; AVELINO, A.;P.;A.; SARON, M.; L.; G. Estado nutricional, sintomas do climatério e qualidade de vida. Cadernos UniFOA. Edição Especial do Curso de Nutrição, 2013.

DESPRÉS, J.P.; LEMIEUX, I.; PRUD'HOMME, D. Treatment of obesity: need to focus on high risk abdominally obese patients. B.M.J.; v.322, n.7288, p.716-720, 2001.

FISBERG, R.; M.; MARCHIONI, D.; M.; L.; COLUCCI, A.; C.; A. Avaliação do consumo alimentar e da ingestão de nutrientes na prática clínica. Arq Bras Endocrinol Metab. P.53-5. 2009.

FRANÇA, P.; A. Estado nutricional e risco de doença cardiovascular de mulheres no climatério atendidas em um ambulatório da cidade de São Paulo. [dissertação]. São Paulo: Universidade de São Paulo - USP; 2003.

GALLON, C.; W. Perfil nutricional e qualidade de vida de mulheres no climatério [dissertação]. Porto Alegre: Universidade Federal do Rio Grande do Sul; 2009.

GALLON, C.; W; WENDER, M.; C.; O. Estado nutricional e qualidade de vida da mulher climatérica. Revista Brasileira de Ginecologia Obstetria. Caxias do Sul, v. 4, n. 34. 2012.

GIL, A.; C. Como elaborar projetos de pesquisa. 6. ed. São Paulo: Atlas, 184p. 2016.

HOFFMANN, M.; MENDES, K.; G.; CANUTO, R.; GARCEZ, A.; S.; THEODORO, H.; RODRIGUES, A.; D.; OLINTO, M.; T.; A. Padrões alimentares de mulheres no climatério em atendimento ambulatorial no Sul do Brasil. Ciência \& Saúde Coletiva, 20 (5): 15651574. 2015.

LEÃO, A.; L.; M.; SANTOS, L.; C. Consumo de micronutrientes e excesso de peso: existe relação? Rev Bras Epidemiol v.15 (1): 85-95. 2012. 
LISBÔA, K.; O.; CRUZ, C.; S. Prevalência de sintomas climatéricos em mulheres na pré e transição menopáusica : estudo de base populacional. [dissertação]. Porto Alegre: Universidade Federal do Rio Grade do Sul; 2009.

LOHMAN, T. G.; ROCHE, A. F.; MARTORELL, R. Anthropometric standardization reference manual. Champaign: Human Kinetics, 1992.

LORENZI, D.; R.; S.;P.; D, CATAN, L.;B.; MOREIRA, K.; ARTICO, G.; R. Assistência à mulher climatérica: novos paradigmas. Rev Bras Enferm. 62 (2) :287-93. 2009.

MARTINAZZO, J.; ZEMOLIN, G.; P.; SPINELLI, R.; BAGGIO, Z.; V.; POLACHINI, S.; CENI, G.; C. Avaliação nutricional de mulheres no climatério atendidas em ambulatório de nutrição no norte do Rio Grande do Sul, Brasil. Ciência \& Saúde Coletiva, 18(11), 33493356. 2013.

MENDONCA, Eliana Azevedo Pereira de. Representações médicas e de gênero na promoção da saúde no climatério/menopausa. Ciênc. saúde coletiva, Rio de Janeiro, v. 9 , n. 1, p. 155-166, 2004 .

NATIONAL CHOLESTEROL EDUCATION PROGRAM. Third report of the National Cholesterol Education Program (NCEP) Expert Panel on detection, evaluation, and treatment of high blood cholesterol in adults (adult treatment panel III): Executive summary. Bethesda: National Cholesterol Education Program National Heart, Lung, and Blood Institute/ National Institutes of Health, 2005.

NESIL, A.; D.; CORRADINI, A.; C.; G.; FELICIO, M.; L. Implicações da obesidade no climatério e menopausa. Revista Brasileira de Obesidade, Nutrição e Emagrecimento. v. 2, n. 8, p.123-139, 2008.

NOSER, T.; M.; MOREIRA, N.; L.; S.; ANDRADE, K.; C. Avaliação dietética de mulheres climatéricas atendidas em uma clínica-escola de nutrição no município de São Paulo. Revista Brasileira de Ciências da Saúde. 2009.

OLIVEIRA, D.; M.; JESUS, M.; C.; P.; MERIGHI, M.; A.; B. Climatério e sexualidade: a compreensão dessa interface por mulheres assistidas em grupo. Texto \& Contexto Enferm. 17 (3): 519-26. 2008.

ORSATTI, F.; L.; NAHAS, E.; A.; P.; NAHAS, N.; J.; MAESTÁ, N.; PADOANI, N.; P.; ORSATTI, C.; L. Indicadores antropométricos e as doenças crônicas não transmissíveis em mulheres na pós-menopausa da região sudeste do Brasil. Revista Brasileira de Ginecologia e ObstetriCia. 30(4);182-9. 2008.

PEDRO AO, PINTO-NETO AM, COSTA-PAIVA L, OSIS MJ, HARDY E. [Climacteric women seeking medical care, Brazil]. Rev Saúde Pública. 2002;36(4):484-90.

PEDRO AO, PINTO-NETO AM, COSTA-PAIVA LH, OSIS MJ, HARDY EE. [Climacteric syndrome: a population-based study in Campinas, SP, Brazil]. Rev Saúde Pública. 2003;37(6):735-42. 
PEREIRA EF, TEIXEIRA AS, BORGATTO AF, DARONCO LSE. Relação entre diferentes indicadores antropométricos e a percepção da imagem corporal em idosas ativas. Rev Psiq Clín. 36(2): 54-9, 2014.

PEREIRA, D.; C.; L.; LIMA, S.; M.; R.; R. Prevalência de sobrepeso e obesidade em mulheres após a menopausa. Arq Med Hosp Fac Cienc Med Santa Casa São Paulo, 60:1-6. 2015.

PHILIPPI, S. T. Redesenho da Pirâmide Alimentar Brasileira para uma alimentação saudável, 2013. Disponível em Acesso em 18 de setembro de 2018.

PITOMBEIRA, R.; LIMA, F.; E.; T.; MAGALHÃES, F.; J.; CUSTÓDIO, I.; L.; OLIVEIRA, S.; K.; P. Sintomatologia e modificações no cotidiano das mulheres no período do climatério. Cogitare Enfermagem, Curitiba, v. 16, n. 3, p. 517-523. 2011.

SANTOS, K.; M.; O.; AQUINO, R.; C. Grupo dos óleos e gorduras. In: Philippi ST, organizador. Pirâmide dos alimentos: Fundamentos básicos da nutrição. 1a Edição. Barueri: Manole; 241-292. 2008.

SBC - Sociedade Brasileira de Cardiologia. [homepage na internet]. IV Diretriz Brasileira Sobre Dislipidemias e Prevenção da Aterosclerose Departamento de Aterosclerose da Sociedade Brasileira de Cardiologia. Arquivos brasileiros de cardiologia. 2007. [acesso em 09 set 2018].

SILVA, L.; M. Avaliação Nutricional e Consumo Alimentar de Mulheres na Menopausa [dissertação]. Criciúma: Universidade do Extremo Sul Catarinense; 2010.

SILVA, P.; M.; C.; CABRAL, J.; C.; R.; VASCONCELOS, C.; M.; L. Ingestão do cálcio na obesidade de mulheres atendidas pelo Sistema Único de Saúde. Rev Nutr. v. 23. n. 3. p. 357-367. 2010.

TARDIVO, A.; P. Investigação do consumo alimentar e dos indicadores da composição corporal das mulheres na pós-menopausa [dissertação]. Botucatu: Faculdade de Medicina de Botucatu, UNESP; 2008.

WU X, CAI H, KALLIANPUR A, GAO YT, YANG G, CHOW WH, et al. Age at menarche and natural menopause and number of reproductive years in association with mortality: results from a median followup of 11.2 years among 31,955 naturally menopausal Chinese women. PLoS One. 2014;9(8):e103673.

ZANOTELLI SS, RESSEL LB, BORGES ZN, JUNGES CF, SANFELICE C. Vivências de mulheres acerca do climatério em uma unidade de saúde da família. Rev pesqui cuid fundam (Online) [Internet]. 2012 [acesso em: 18 fev 2014];4(1):2800-11. Disponível em: http://www.seer.unirio.br/index.php/cuidadofundamental/article/view/1632/pdf_492 


\section{Capítulo 12}

\section{A relação entre gravidez e anemia no Brasil: uma revisão de literatura}

\section{Jéssica Lorena dos Santos Rocha \\ Sabrina da Fonseca Meireles \\ Francimeire Gomes Pinheiro}

Resumo: A anemia é um problema de saúde pública mundial de intensificação moderada e prevalente em mulheres grávidas no Brasil. Considerando a estreita relação entre anemia e gravidez, e o aumento de risco de mortalidade materna e perinatal em gestantes anêmicas em todo o território nacional, foi realizado um levantamento na literatura científica sobre a prevalência da anemia gestacional em mulheres brasileiras. As pesquisas foram realizadas nas plataformas eletrônicas: Biblioteca Virtual em Saúde (BVS), LILACS (Literatura Latino-Americana em Ciências de Saúde), MEDLINE (Medical Literature Analysis and Retrievel System Online), SCIELO (Scientific Eletronic Library Online), SCIENCE DIRECT e SPRINGER. Foram identificados 23 artigos sobre a temática e após análise criteriosa, somente 15 foram incluídos na elaboração desta revisão. Os estudos analisados apresentaram resultados importantes sobre a prevalência da anemia em mulheres grávidas em todas as regiões do país. Estes dados são fundamentais para sinalizar aos profissionais de saúde da atenção básica a necessidade de intervenção quando necessário, para prevenir a ocorrência de resultados maternos e neonatais adversos.

Palavras-Chave: Anemia ferropriva, Gestantes, Hemoglobina, Pré-natal, Saúde Pública. 


\section{INTRODUÇÃO}

A anemia tem como definição pela Organização Mundial da Saúde (2013), a condição na qual o número de células vermelhas do sangue e a sua capacidade de transporte de oxigênio são insuficientes para atender às necessidades fisiológicas, que variam de acordo com idade, sexo, altura e gravidez. É considerada a carência nutricional mais prevalente no mundo, principalmente nos países em desenvolvimento como o Brasil (VIEIRA et al., 2010).

Estima-se que existam no mundo cerca de 1,62 bilhões de pessoas anêmicas, com maior prevalência nas crianças menores de cinco anos e entre mulheres grávidas (WHO, 2008). A anemia não fisiológica acomete $20 \%$ a $80 \%$ das gestações. Destas, a anemia por deficiência de ferro é a mais comum. No Brasil, a anemia ferropriva é prevalente em populações em evidente condição de iniquidade social (VIEIRA et al., 2010). Em adultos está associada principalmente à queda de produtividade, sendo as mulheres em idade reprodutiva as mais vulneráveis (WHO, 2001).

No Brasil, dependendo da região, as mulheres gestantes apresentam dificuldades específicas para realizar o pré-natal, seja por falta de acesso ao serviço público de saúde; por crenças e costumes, como observado em mulheres indígenas que sofrem por terem vergonha de serem examinadas por especialistas que não são indígenas e por na maioria das vezes serem homens (AZEVEDO, 2009); ou por preconceito, no caso de mulheres negras que sofrem de discriminação ao buscar atendimento no sistema de saúde público (CORDEIRO e FERREIRA, 2009).

Diante da importância da anemia, considerada um problema de saúde pública de intensificação moderada no mundo e do aumento de risco de mortalidade materna e perinatal em gestantes anêmicas em todo o território nacional, propôs-se a realização de um levantamento de trabalhos científicos na literatura, sobre a prevalência da anemia gestacional em mulheres brasileiras, visando contribuir com dados atuais sobre a temática no Brasil que possam sinalizar aos profissionais de saúde da atenção básica a importância do acompanhamento das gestantes e de intervenção quando necessário, para prevenir a ocorrência de resultados maternos e neonatais adversos.

\section{REFERENCIAL TEÓRICO}

\subsection{PROCESSO ANÊMICO ENTRE AS GRÁVIDAS NO MUNDO}

A anemia é um grave problema de saúde pública que afeta países desenvolvidos e em desenvolvimento, com grandes consequências para a saúde humana e também para o desenvolvimento socioeconômico. Ocorre em todas as fases da vida, porém, é mais prevalente em mulheres grávidas e crianças pequenas. Estima-se em todo o mundo que 41,8\% das grávidas e 30,2\% das não grávidas sejam anêmicas (BENOIST et al., 2008).

0 processo de desenvolvimento da anemia ocorre de forma lenta. Inicia-se com a depleção dos depósitos de ferro no corpo e na medula óssea, constatado com a diminuição da ferritina. Em decorrência disso, a eritropoese é comprometida, observada por valores inferiores da hemoglobina corpuscular média (HCM) e volume corpuscular médio (VCM). Em resumo, observa-se a diminuição dos valores de hemoglobina e hematócrito, o que compromete a oxigenação tecidual, instalando-se então o quadro de anemia (RODRIGUES et al., 2010).

A deficiência de ferro em mulheres é mais evidente no período da menacme, 
associada à menorragia. Em mulheres entre 20 e 49 anos é de 11\%, de $5 \%$ entre 50 a 69 anos, e de $2 \%$ na faixa etária acima de 70 anos (DALLMAN et al., 1984). As causas são basicamente a baixa ingesta, absorção deficiente e perdas sanguíneas, incluindo fluxo menstrual excessivo (RODRIGUES et al., 2010) (figura 1). Ademais, as mulheres são mais propensas à anemia, pois as suas reservas de ferro tendem a ser menores que nos homens devido ao fluxo menstrual.

Figura 1. Representação das causas da deficiência de ferro na mulher adulta.

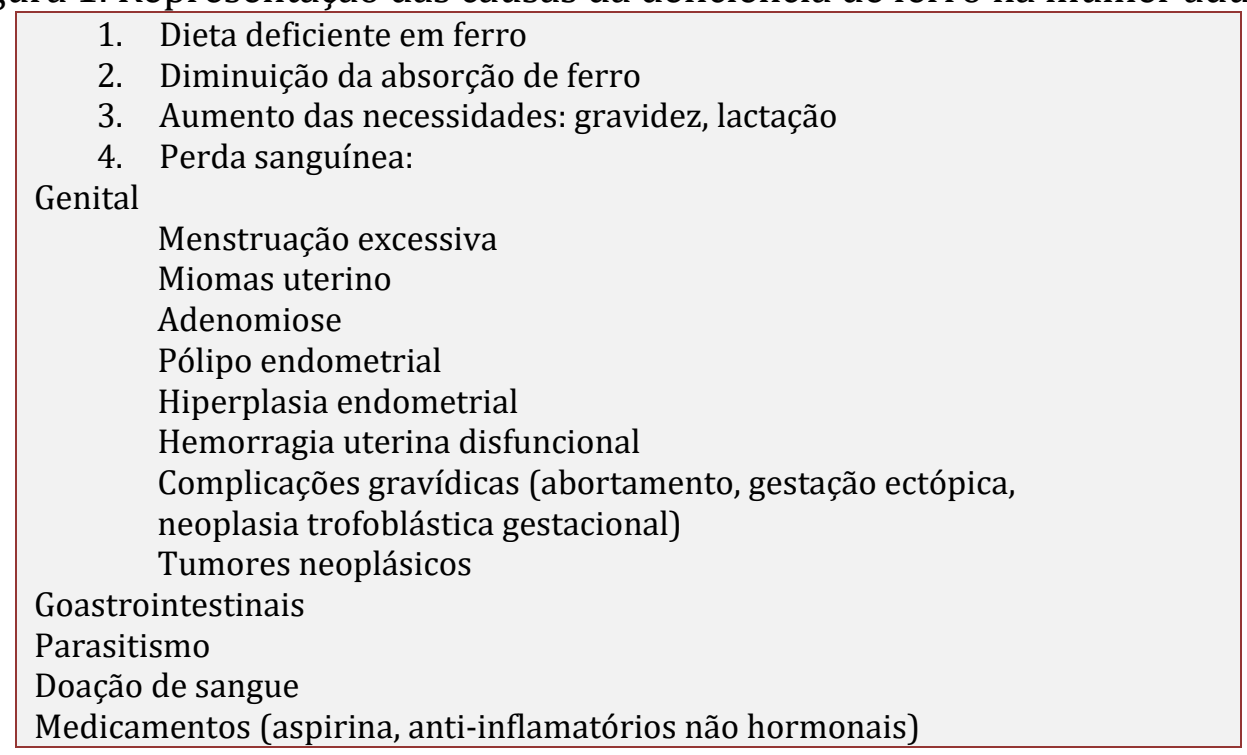
Fonte: Rodrigues et al. (2010).

A OMS estima que a prevalência de anemia em mulheres grávidas é de 14\% nos países desenvolvidos e 51\% nos países em desenvolvimento. Essa prevalência global da anemia vem sendo acompanhada ao longo dos anos. Dados da OMS de 1985 mostram que 30\% da população mundial era anêmica (DE MAEYER et al., 1985); de 1992, 37\% de todas as mulheres eram anêmicas (WHO, 1992) e; mais recentemente, a anemia afetou $24,8 \%$ da população mundial, incluindo $42 \%$ das mulheres grávidas, 30\% das mulheres não grávidas e 47\% das crianças em idade pré-escolar (BENOIST et al., 2008) (figura 2).

Figura 2. Prevalência de anemia em mulheres grávidas no mundo (\%).

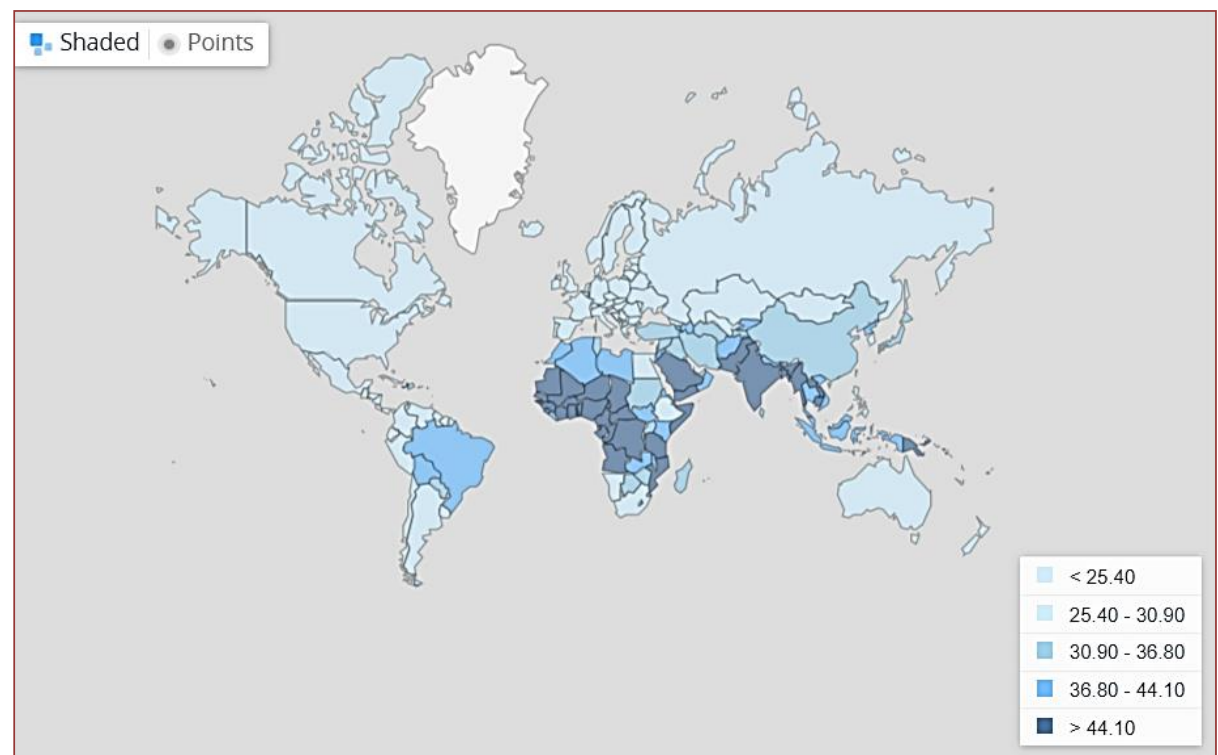


A anemia na gestação é definida como o índice de hemoglobina inferior a $11 \mathrm{~g} / \mathrm{dL}$, podendo ser classificada como leve, moderada e grave. A anemia leve corresponde a $\mathrm{Hb}=9-10,9 \mathrm{~g} / \mathrm{dL}$; moderada $(\mathrm{Hb}=7 \mathrm{a} 8,9 \mathrm{~g} / \mathrm{dL})$ e; grave $(\mathrm{Hb}<\mathrm{ou}=8 \mathrm{~g} / \mathrm{dL})(\mathrm{MS}, 2012)$. Na gestação, a ocorrência de anemia representa aumento de risco de mortalidade materna e perinatal (VIEIRA et al., 2010), pois a quantidade de ferro e folato obtida na alimentação pode não atender às demandas adicionais impostas às reservas maternas de ferro pelo feto em crescimento, pela placenta e pelo aumento da massa de hemácias materna (WHO, 2001). Estudos mostram que gestantes com anemia no $2^{\text {o }}$ trimestre apresentam risco de parto pré-termo (KLEBANOFF et al., 1991); influencia a vascularização placentária, alterando a angiogênese durante o início da gravidez (KADYROV et al., 1998) e aumenta o risco de baixo peso de bebês ao nascer (REN et al., 2007).

A anemia ferropriva é o distúrbio nutricional mais comum no mundo, afetando 2 bilhões de pessoas (WHO, 2012). A demanda total de ferro na gravidez é de cerca de 900 mg (com uma faixa de 700-1400 mg), dos quais, cerca de 500-600 mg são contabilizados pelo útero e seu conteúdo. Cerca de 150-200 mg são perdidos na perda de sangue no parto e uma quantidade semelhante é gasta na lactação. As gestantes nem sempre conseguem priorizar a saúde durante a gravidez, pois a maioria se dedicam a diversos trabalhos que as mantêm ocupadas ao longo do dia. Portanto, a identificação dos fatores de risco que contribuem para a anemia em gestantes é vital para sua prevenção e controle (figura 3).

Figura 3. Principais determinantes da anemia por deficiência de ferro em mulheres grávidas e nos primeiros anos de vida do bebê.

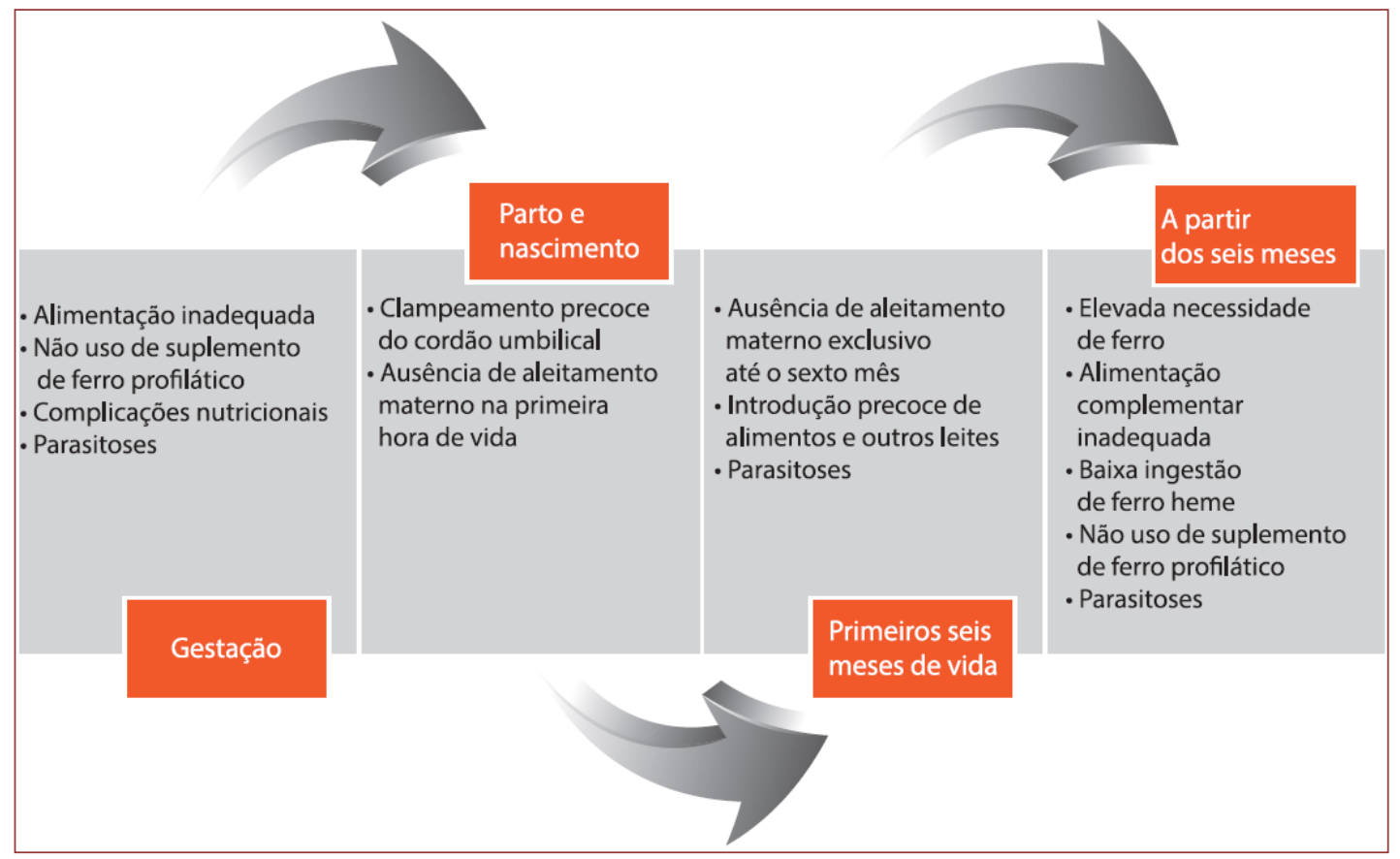

Fonte: Ministério da Saúde (2013).

As estratégias de prevenção e controle da anemia, segundo o Ministério da Saúde (2013), devem priorizar intervenções que contribuam para o enfrentamento dos seus principais determinantes, como (1) Suplementação profilática com ferro e ácido fólico; (2) Ingestão de alimentos que contenham farinhas enriquecidas com ferro e ácido fólico e; (3) Alimentação adequada e saudável com ingestão de ferro de alta 
biodisponibilidade. A recomendação de alimentos refere-se à fortificação de farinhas de trigo e milho com ferro e ácido fólico - Resolução RDC no 344, de 13 de dezembro de 2002, da Anvisa.

\subsection{PROMOÇÃO DA MATERNIDADE E PECULIARIDADES DAS REGIÕES BRASILEIRAS}

No decorrer da gestação, o equilíbrio fisiológico do organismo materno é bastante alterado, tornando-se, geralmente, um dos poucos momentos de contato com os serviços de saúde e uma boa oportunidade para o rastreamento de enfermidades (SILVA et al., 2015).

O Brasil é um país de nível continental e muito heterogêneo nas mais diversas áreas, incluindo a assistência pré-natal. Cada região tem suas peculiaridades e necessidades, bem como suas doenças mais prevalentes, o que obriga atendimento diferenciado para atender as necessidades regionais. Por isso, é de suma importância ter conhecimento do perfil clínico e sociodemográfico de gestantes de uma cidade, no intuito de otimizar o atendimento de acordo com cada necessidade específica (SILVA et al., 2015).

As investigações epidemiológicas evidenciam as desigualdades raciais no Brasil e apontam que as pessoas negras, quando comparadas às brancas, apresentam inúmeras desvantagens neste sentido. Entender essas desigualdades no que diz respeito ao acesso e utilização dos serviços de saúde se faz necessário para se pensar em estratégias para minimização de desigualdades, atendimento respeitoso e humano, principalmente no que tange à saúde e políticas públicas (CARDOSO e COCKELL, 2019).

Para o Ministério da Saúde, a promoção da maternidade segura é um dos compromissos para o Brasil, sobressaindo a implementação da Estratégia de Saúde da Família, a qual prioriza ações de promoção da saúde das famílias, com ênfase na atenção básica, na responsabilidade sanitária e promoção do cuidado integral, tendo como uma de suas prioridades as ações promocionais específicas ao período gravídico-puerperal.

Dentro do contexto supracitado, em 2004, houve a implantação da Política Nacional de Atenção Integral a Saúde da Mulher (PNAISM) com diretrizes para humanização e qualidade do atendimento dos vários segmentos da população feminina, buscando compreender os diferentes momentos da vida da mulher e não apenas na atenção ao ciclo gravídico-puerperal (SOUZA et al., 2013).

\section{MATERIAL E MÉTODOS}

Este estudo é uma revisão baseada na literatura especializada, selecionada por meio de buscas nas plataformas de pesquisa Biblioteca Virtual em Saúde (BVS), LILACS (Literatura Latino-Americana em Ciências de Saúde), MEDLINE (Medical Literature Analysis and Retrievel System Online), SCIELO (Scientific Eletronic Library Online), SCIENCE DIRECT e SPRINGER. A última pesquisa foi realizada em fevereiro de 2021, utilizando os descritores: Anemia na gravidez, Anemia em mulheres grávidas brasileiras, Anemia em gestantes no Brasil.

Foram incluídos na redação da revisão, somente estudos completos realizados no Brasil, com resultados específicos à abordagem "prevalência da anemia gestacional em mulheres brasileiras". Apenas artigos publicados no período compreendido entre 1990 e 
2020 foram considerados e nenhuma restrição de idioma foi aplicada.

\section{RESULTADOS E DISCUSSÃO}

Foram identificados 25 estudos sobre a temática. Destes, apenas 15 artigos contendo as especificações pré-definida na metodologia foram incluídos nesta revisão. 0 resultado de cada estudo, foi descrito em resposta às questões: (1) Como é realizado o diagnóstico da anemia na gravidez? (2) Qual é a incidência de anemia em gestantes do País?

\subsection{COMO É REALIZADO O DIAGNÓSTICO DA ANEMIA NA GRAVIDEZ?}

Na assistência pré-natal, o diagnóstico da anemia é realizado por meio de anamnese, avaliação física e exames laboratoriais, que avaliam os índices hematimétricos e o perfil de ferro sanguíneo, em especial pela dosagem da ferritina sérica (RODRIGUES et al., 2010). Geralmente, o diagnóstico da anemia é realizado por meio do hemograma, do esfregaço sanguíneo periférico, da contagem dos reticulócitos e pela dosagem da quantidade do ferro sérico (JOHNSON-WIMBLEY e GRAHAM, 2011; CAMITTA et al., 2012). Consideram-se anêmicas as gestantes que apresentam níveis de $\mathrm{Hb}$ inferiores a $11 \mathrm{~g} / \mathrm{dL}$, tendo dor base a classificação do Ministério da Saúde, anemia leve $(\mathrm{Hb}=9-10,9 \mathrm{~g} / \mathrm{dL})$, moderada $(\mathrm{Hb}=7$ a $8,9 \mathrm{~g} / \mathrm{dL})$ e grave $(\mathrm{Hb})$.

\subsection{QUAL É A INCIDÊNCIA DE ANEMIA EM GESTANTES DO PAÍS?}

A OMS estima que a prevalência de anemia gestacional no Brasil seja de 29,1\%, o que a caracteriza como um problema de saúde pública de intensidade moderada. Em uma revisão bibliográfica com dados da anemia em gestantes adultas no Brasil, a partir da década de 70 até os anos 2000, obteve-se a prevalência da anemia variando de 8,9 a 57,1\% (CÔRTES et al., 2009). Outro dado é da Pesquisa Nacional de Demografia e Saúde da Criança e da Mulher (PNDS) de 2006 que constatou após análise de mulheres em idade reprodutiva não grávidas, que $29,4 \%$ das mulheres brasileiras são anêmicas, sendo as maiores prevalências encontradas no Nordeste $(39,1 \%)$ e as menores no Centro-Oeste (20,1\%), apresentando na região Sul prevalência de 24,8\%.

Na Região Norte, Neves et al. (2019) estimaram a prevalência e os fatores associados à cegueira noturna gestacional e anemia materna em 1.525 mulheres grávidas da cidade de Cruzeiro do Sul, Estado do Acre. Cerca de 11,5\% das mulheres apresentaram cegueira noturna gestacional e 39,4\% anemia materna. A prevalência alarmante da cegueira noturna foi associada ao tabagismo durante a gravidez e ao comparecimento a menos de 6 consultas pré-natais. Os fatores associados à anemia materna foram idade materna $<19$ anos, malária gestacional, falta de suplementos de micronutrientes durante a gravidez e, ao comparecimento a menos de 6 consultas prénatais. Em Manaus-AM, Costa et al. (2009) avaliaram a anemia em grávidas, associando os resultados da dosagem de hemoglobina e hematócrito com a análise de marcadores do perfil sérico do ferro. Das 92 grávidas avaliadas, 26,1\% apresentaram níveis de hemoglobina abaixo de $11 \mathrm{~g} / \mathrm{dL}$. Observou-se que 17,4\% das grávidas com níveis normais de hemoglobina apresentavam níveis inadequados de ferro sérico e 9,8\% apresentavam níveis baixos de ferritina sérica.

Na Região Nordeste, Figueiredo et al. (2019) avaliaram a associação entre anemia 
materna e baixo ou insuficiente peso ao nascer em 622 mulheres. Concluíram que a anemia materna foi considerada fator de risco para baixo ou insuficiente peso ao nascer, após ajuste da medida de efeito para idade materna, renda familiar, infecção urinária, paridade, consumo de bebida alcoólica durante a gravidez e índice de massa corporal gestacional: RR ajustado = 1,38 (IC 95\%: 1,07 a 1,77). No estudo de Ferreira et al. (2008) a prevalência e fatores de risco associados à anemia em gestantes da região semi-árida de Alagoas foi de $50 \%$ das $78 \%$ das gestantes que estavam sob acompanhamento prénatal. Destas, $79,3 \%$ se encontravam no segundo ou terceiro trimestre de gestação. E, Oliveira et al. (2010) obtiveram o percentual de anemia em 428 mulheres de 28,3\%, sendo a maior ocorrência entre as mulheres com mais membros no domicílio ( $R P=1,49$; IC95\% 1,01-2,22; $p=0,046)$ e aquelas que viviam com insegurança alimentar $(R P=1,43$; IC 95\%) 1,00-2,04; $\mathrm{p}=0,047$ ).

Em Campo Grande-MS, Região Centro-Oeste, Sakamoto et al. (2012) identificaram o perfil demográfico e a frequência de anemia e hemoglobinopatias em 215 gestantes, sendo $20 \%$ delas, adolescentes; $36,3 \%$ com ensino fundamental incompleto; 53,0\% eram não caucasoides; 43,3\% eram nascidas em Campo Grande-MS; e 21,1\% tinham descendência europeia. Destas, $17,7 \%$ apresentaram algum tipo de anemia e, na avaliação das hemoglobinopatias, foram detectados $4,7 \%$ de pacientes com alguma hemoglobina anormal, com as frequências: 3,3\% com $\mathrm{HbAS} ; 0,9 \%$ com $\mathrm{HbAC}$; e 0,5\% com talassemia $\beta$ intermediária. Já, no estudo de Camargo et al. (2013) ao avaliar 146 mulheres grávidas em Cuiabá, Mato Grosso, observou-se concomitância de excesso de peso e deficiência de ferro.

Na cidade de São Paulo, Guerra et al. (1990) realizaram o estudo das gestantes de primeira consulta, na rede pública do subdistrito do Butantan, Município de São Paulo. Concluíram que a prevalência de anemia, identificada pela concentração de hemoglobina inferior a 11,6 g/dL, ocorreu em 12,4\% das gestantes, sendo menor a prevalência de anemia no primeiro trimestre gestacional do que no segundo e terceiro trimestres de gestação; e as gestantes com mais de três partos tiveram prevalência significativamente maior do que as gestantes com até três partos. Em outro estudo, Fujimori et al. (2000) verificaram que das 79 gestantes adolescentes de primeira consulta pré-natal em São Paulo, 13,9\% eram anêmicas. Em Minas Gerais, Rocha et al. (2015) avaliaram 168 gestantes atendidas no pré-natal do único centro de saúde disponível no município de Viçosa para a baixa renda. Foi encontrada prevalência de $21,4 \%$ de mulheres anêmicas, sendo $5,6 \%, 20,3 \%$ e $26,3 \%$ para o primeiro, o segundo e o terceiro trimestres, respectivamente.

Na Região Sul, Américo e Ferraz (2011), observaram a prevalência de anemia em 6,18\% das gestantes atendidas em Unidades Básicas de Saúde em Campo Mourão, Paraná, de 2005 a 2008, considerada leve, segundo a classificação da OMS. Em outro estudo realizado com 157 parturientes do Hospital Escola da Universidade Federal de Pelotas, Rio Grande do Sul, a prevalência de anemia foi de $14,7 \%$, e as anêmicas apresentaram hemoglobina significativamente menor que as não anêmicas. Neste estudo não houve associação significativa entre anemia e realização de pré-natal, uso de suplementos e hábitos alimentares. A prevalência de anemia gestacional foi aquém da estimada para o Brasil, possivelmente devido à quase universalidade do pré-natal e ao alto índice de uso de suplementação de ferro (ERLET et al., 2013).

Em relação as mulheres indígenas, Borges et al. (2016) avaliaram a prevalência de anemia e fatores associados em mulheres indígenas a partir de dados da Primeira Pesquisa Nacional de Saúde e Nutrição Indígena do Brasil. Com base em dados de 6.692 
mulheres indígenas, o nível de hemoglobina médio nacional foi de $12,39 \mathrm{~g} / \mathrm{dL}$ (IC 95\%: 12,29-12,50). A prevalência de anemia foi alta (33,0\%; IC 95\%: 30,40-35,61\%) e mostrou disparidades regionais pronunciadas. A prevalência de anemia em mulheres indígenas brasileiras foi $12 \%$ maior do que as estimativas nacionais para mulheres em idade reprodutiva. A prevalência de anemia e os níveis médios de hemoglobina entre as mulheres indígenas parecem ser parcialmente explicados por alguns fatores de risco previamente reconhecidos, como status socioeconômico, índice de massa corporal e malária.

\section{CONCLUSÃO}

Em todas as pesquisas verificadas, houve a prevalência de anemia na gestação, o que caracteriza essa situação como um problema de saúde pública no Brasil, mesmo com as políticas nacionais atuais de combate à deficiência. A maioria dos autores relaciona a maior prevalência da anemia às condições sanitárias impróprias, às dietas insuficientes em ferro e micronutrientes essenciais e à falta de acesso aos serviços básicos de saúde nas áreas mais carentes do país e em comunidades indígenas. Desta forma, o conhecimento do estado de saúde e seus determinantes é fundamental para orientar políticas públicas voltadas para o controle da carga de anemia em populações carentes, para prevenir a ocorrência de resultados maternos e neonatais adversos.

\section{REFERÊNCIAS}

AMÉRICO, S. C. M.; FERRAZ, F. N. Prevalência de anemias em gestantes do município de Campo Mourão - PR entre os períodos de 2005 a 2008. Semina: Ciências Biológicas e da Saúde, Londrina. 32 (1): 59-68. 2011.

AZEVEDO, M. Saúde reprodutiva e mulheres indígenas do alto rio negro. Caderno CRH. 22 (57): 464. 2009.

BENOIST, B.; MCLEAN, E.;EGLI, I.; COGSWELL, M. Worldwide prevalence of anaemia 1993-2005. Geneva, SwitzerlandWorld Health Organization. 2008.

BORGES, M. C., et al. Anemia among indigenous women in Brazil: findings from the First National Survey of Indigenous People's Health and Nutrition BMC Women's Health.16:7. 2016.

BRASIL. Ministério da Saúde. Pesquisa nacional de demografia e saúde da criança e da mulher (PNDS 2006): Dimensões do processo reprodutivo e da saúde da criança. 1. ed., Brasília. 255p. 2009.

BRASIL. Ministério da Saúde. Manual técnico gestação de alto risco. 5. Ed. Brasília. 2012.

CAMARGO, R. M. S.; PEREIRA, R. A.; YOKOO, E. M.; SCHIRMER, J. Factors associated with iron deficiency in pregnant women seen at a public prenatal care service. Rev. Nutr. 26:4 .2013.

CAMITTA, B. M.; SLYE, R. J. Optimizing Use of the Complete Blood Count. Pediatr. Polsk. 87: 72-7. 2012. 
CARDOSO, E. M.; COCKELL, F. F. Atenção à saúde da mulher negra no ciclo gravídico puerperal: percepções em primeira pessoa. Cad. Gên. Tecnol., Curitiba. 12 (40): 111131. 2019.

CORDEIRO, R. C.; FERREIRA, S. L. Discriminação racial e de gênero em discursos de mulheres negras com anemia falcifome. Esc Anna Nery. Revista de Enfermagem. 13 (3): 352-358. 2009.

CÔRTES, M.H.; VASCONCELOS, I.A.L.; COITINHO, D.C. Prevalência de anemia ferropriva em gestantes brasileiras: uma revisão dos últimos 40 anos. Revista de Nutrição. 22 (3): 409-418. 2009.

COSTA, C. M.; BRUM, I. R.; LIMA, E. S. Anemia e marcadores séricos da deficiência de ferro em grávidas atendidas na rede pública municipal de Manaus, Amazonas, Brasil. Acta Amazonica, 39(4): 901-906. 2009.

DALLMAN, P. R.; YIP, R.; JOHNSON, C. Prevalence and causes of anemia in the United States, 1976 to 1980. Am J Clin Nutr. 39 (3): 437-45. 1984.

DE MAEYER E.; ADIELS-TEGMAN, M. The prevalence of anaemia in the world. World Health Stat Q. 38 (3): 302-316. 1985.

ELERT, V. W.; MACHADO, A. K. F.; PASTORE, C. A. Anemia e nutrição em parturientes. Alim. Nutr. = Braz. J. Food Nutr. 24 (3): 353. 2013.

FERREIRA, H. S.; MOURA, F. A.; JÚNIOR, C. R. C. Prevalência e fatores associados à anemia em gestantes da região semi-árida do Estado de Alagoas. Rev Bras Ginecol Obstet. 30 (9): 445-51. 2008.

FIGUEIREDO, A.; GOMES-FILHO, I. S.; BATISTA, J.; ORRICO, G. S.; PORTO, E.; CRUZ PIMENTA, R. M.; DOS SANTOS CONCEIÇÃO, S.; BRITO, S. M.; RAMOS, M.; SENA, M.; VILASBOAS, S.; SEIXAS DA CRUZ, S.; PEREIRA, M. G. Maternal anemia and birth weight: A prospective cohort study. PloS one. 14(3): e0212817. 2019.

FUJIMORI, E.; LAURENTI, D.; CASSANA, L. M. N.; OLIVEIRA, I. M. V.; SZARFARC, S. C. Anemia e deficiência de ferro em gestantes adolescentes. Rev. Nutr. 13: 3. 2000.

GUERRA, E. M.; BARRETTO, O. C. 0.;** ADELAIDE JOSÉ VAZ**** MARIA BEATRIZ SILVEIRA. Prevalência de anemia em gestantes de primeira consulta em centros de saúde de área metropolitana, Brasil. Ver Saúde Pública. S. Paulo. 24 (5): 380-6. 1990.

JOHNSON-WIMBLEY, T. D.; GRAHAM, D. Y. Diagnosis and management of iron deficiency anemia in the 21st century. Ther Adv Gastroenterol. 4: 177-84. 2011.

KANDYROV, M., et al. Increased fetoplacental angiogenesis during first trimester in anemic woman. Lancet. 352:1747. 1998.

KLEBANOFF, M. A., et al. Anemia and spontaneous preterm birth. Am J Obstet Gynecol. 164:59. 1991.

NEVES, P.; LOURENÇO, B. H.; PINCELLI, A.; MALTA, M B.; SOUZA, R. M.; FERREIRA, M. U.; 
CASTRO, M. C, CARDOSO, M. A, \& Grupo de Estudo MINA-Brasil. Alta prevalência de cegueira noturna gestacional e anemia materna em inquérito de base populacional com puérperas da Amazônia brasileira. PloS one. 14 (7): e0219203. 2019.

OLIVEIRA, J. S.; LIRA, P. I. C.; OSÓRIO, M. M.; SEQUEIRA, L .A. S.; COSTA, E. C.; GONCALVES.; F. C. L. S. P.; BATISTA-FILHO, M. Anemia, hipovitaminose A e insegurança alimentar em crianças de municípios de Baixo Índice de Desenvolvimento Humano do Nordeste do Brasil. Revista Brasileira de Epidemiologia. 13 (4): 651-664. 2010.

OMS - ORGANIZAÇÃO MUNDIAL DA SAÚDE. Wordwide prevalence of anaemia 19932005. WHO Global database on anaemia. World, Health Organization, Geneva, 2008. Disponível em:< http://www.who.int/nutrition/publications/micronutrients/anaemia_iron_deficiency/9 $789241596657 /$ en/ >. Acesso em: 15 Jul 2018.

RODRIGUES, L. P.; JORGE, S. R. P. F. Deficiência de ferro na gestação, parto e puerpério. Rev Bras Hematol Hemoter. 32 (Suppl2): 53-6. 2010.

SAKAMOTO, T. AM.; IVO, M. L.; BRUM, M. A. R.; PONTES, E. R. J. C.; BONINI-DOMINGOS, C. R.; JÚNIOR, M. A. F. Anemia and hemoglobinopathies in pregnant women attended in a public hospital. J Nurs UFPE on line. 6 (7):1576-81. 2012.

SILVA, M. G.; GONTIJO, E. E. L.; FERREIRA, D. S.; CARVALHO, F. S. C.; CASTRO, A. M. O perfil epidemiológico de gestantes atendidas nas unidades básicas de saúde de Gurupi, Tocantins. Universitas: Ciências da Saúde, Brasília. 13 (2): 93-102. 2015.

SOUZA, L. E. A.; ROSA, R. C. R.; DIAS, R. S.; SILVA, J. A. C. Principais agravos em gestantes na atenção básica de saúde. 2013.

VIEIRA, R. C. S.; FERREIRA, H. S. Prevalência de anemia em crianças brasileiras, segundo diferentes cenários epidemiológicos. Revista Nutrição. 23 (3): 433-444. 2010.

WORLD HEALTH ORGANIZATION, The prevalence of anaemia in women: a tabulation of available information, Geneva, SwitzerlandWorld Health Organization. 1992.

WORLD, HEALTH, Organisation. Iron Deficiency Anaemia - Assessment, Prevention and Control. A guide for programme managers. World Health Organisation. 2001.

WHO - World Health Organization. Anaemia: Health topics [homepage na Internet]. 2013. Disponível em: http://www.who.int/topics/anaemia/en/ 


\section{Capítulo 13}

\section{Alterações das papilas gustativas e o estado nutricional dos idosos}

\section{Monique Moldes da Silva \\ Francimeire Gomes Pinheiro}

Resumo: As alterações das percepções paladares são conhecidas, também, por distúrbios das papilas gustativas, sendo esta uma das queixas mais comuns e irritantes nos indivíduos, estes sofrem uma sensação distorcida do sabor, portanto tornam-se suscetíveis às alterações salutares. Diante do exposto, o objetivo da pesquisa foi demonstrar através da revisão de literatura as principais alterações ocorridas nas papilas gustativas dos idosos, com detecção dos gostos básicos doce, salgado, amargo e azedo, sendo essas fisiológicas ou de causas secundárias, com presença ou não, de patologias. Além de sua relação com a diminuição da qualidade de vida referente ao estado nutricional do indivíduo. 0 estudo caracterizou-se por uma revisão bibliográfica de caráter exploratório descritivo e qualitativo, com coleta nas bases de dados PubMed, SCIELO e LILACS no período de Julho a Agosto de 2018, com ênfase nos últimos dez anos, reunindo um total de 50 referências para sua elaboração e revisão final. As alterações que ocorrem no processo de envelhecimento de uma pessoa para outra são dependentes de fatores como estilo de vida, condições socioeconômicas e doenças crônicas. Dentre as principais alterações fisiológicas que podem afetar o comportamento alimentar dos idosos, evidenciam o decréscimo da sensibilidade gustativa para os gostos primários e pode-se salientar também: falta de higiene bucal; a perda dentaria; polifarmácia; tabagismo; alcoolismo e as diversas condições clínicas crônicas, das alterações fisiológicas que colaboram para o decrescimento da sensibilidade da percepção gustativa no qual são contribuintes consideravelmente nos distúrbios do paladar, nesse ponto de vista, a literatura científica demonstra que alterações da sensibilidade gustativa permeiam o processo de envelhecimento com impacto potencial sobre o estado nutricional. Conclui-se que novos estudos são necessários para uma avaliação mais precisa, pois o assunto abordado ainda é escasso de material cientifico o que dificulta uma melhor avaliação desse público idoso.

Palavras-chave: Geriatria e qualidade de vida, Alimentação e nutrição, olfato e paladar. 


\section{INTRODUÇÃO}

Nas últimas cinco décadas vêm ocorrendo mudanças na transição demográfica brasileira, principalmente ao que se refere às taxas de mortalidade, fecundidade e o crescimento relativo entre a população maior de 60 anos. Tais mudanças implicam no aumento da expectativa de vida, menor natalidade e envelhecimento da população (LEBRÃO, 2009). Devido à análise da mortalidade e de expectativa de vida, surge a necessidade de investigação com intuito de compreender o estado de saúde, juntamente com os determinantes e as decorrências das perdas da capacidade funcional da população idosa. De acordo com o Estatuto do Idoso, do qual assegura os direitos dos indivíduos considerados idosos, o qual possui a idade igual ou superior a 60 anos (PARAHYBA e VERAS, 2008; ESTATUTO DO IDOSO, 2013).

0 envelhecimento, apesar de ser um processo natural, acarreta uma série de mudanças no organismo, sendo essas estruturais, psicológicas, bioquímicas, anatômicas e principalmente, condições do estado nutricional dessa população mais idosa. É considerada também, uma fase de maturidade, sendo essa caracterizada pelo declínio dessas funções orgânicas, fazendo com que o indivíduo seja suscetível à doenças (SANTOS; MACHADO e LEITE, 2010).

Essas alterações ocorrem principalmente no seu estado nutricional, da qual está associado com as modificações sensoriais do indivíduo, decorrente da redução da sensibilidade para os gostos primários, amargo, doce, salgado e ácido (azedo), podendo estar relacionado também com a visão, audição e olfato (MONTEIRO, 2009). De acordo com dados epidemiológicos essas mudanças começam surgir a partir do período sexagenário, ficando mais intenso após os 70 anos, trazendo consequências à saúde, à qualidade de vida do indivíduo e atingindo principalmente a sua alimentação. Em função das alterações no sabor dos alimentos, há comprometimento do estado nutricional assim como agravamento dos riscos de uma intoxicação alimentar (COELHO e GRANATO, 2014).

As alterações das percepções paladares são conhecidas, também, por distúrbios das papilas gustativas, sendo esta uma das queixas mais comuns e irritantes nos indivíduos, estes sofrem uma sensação distorcida do sabor, portanto tornam-se suscetíveis às alterações salutares. Dois dos fatores primordiais, o cheiro e o gosto dos alimentos, acarretam desinteresse ou até mesmo repugnação, levando a diminuição do apetite e corroborando no déficit nutricional (STRAPASSON et al., 2013).

Cientificamente é comprovado que a dificuldade que os idosos possuem em identificar a intensidade do sal e/ou açúcar nos alimentos, os predispõem a adoçar ou salgar mais os preparos alimentícios, esse fator, gera tendência maior ao surgimento de doenças como hipertensão e diabetes. (MAGALHÃES, 2011; PASSOS; GUIMARÃES e VICTORIA, 2016).

A hipertensão ocorre de forma lenta e silenciosa, exige atenção redobrada, visto que o seu tratamento requer mudanças de hábitos dietéticos e comportamentais, usando maior rigor quanto à prescrição de medicamentos. Nos idosos a prevalência de hipertensão arterial é superior a $60 \%$, com isso, é importante que o paciente tenha um acompanhamento e um diagnóstico correto durante o tratamento (GUSMÃO et al., 2009; BARBOSA et al., 2012).

O sedentarismo, os hábitos alimentares inadequados e o ritmo acelerado de envelhecimento são fatores que contribuem para a incidência do diabetes. 0 indivíduo 
acometido por tal enfermidade pode ser altamente limitado em função dos sintomas, sendo potencial vítima aos índices de morbidade e mortalidade (FRANCISCO et al., 2010).

Faz-se importante uma maior atenção sobre as políticas públicas de saúde e com aprofundamento desta reflexão junto à população idosa, sendo de suma importância o papel das práticas profissionais adequadas, fazendo com que se tenham debates sobre os modos de agir e ver no que tange a este nicho de indivíduos (LOUREIRO, 2008).

Levando em consideração as análises feitas durante toda a trajetória, partindo da perspectiva de melhor qualidade de vida, vem ocorrendo um grande avanço e um novo olhar para a população idosa dentro dos princípios e diretrizes do SUS (Sistema Único de Saúde), do qual visa atenção a saúde, a universalização, a equidade e a integralidade. Essas ações têm ocorrido com o intuito de proporcionar um envelhecimento mais sadio, e com capacidade de viver de forma independente (CRUZ; CAETANO e LEITE, 2010; CATÃO; XAVIER e PINTO, 2011).

Diante do exposto, o objetivo da pesquisa foi demonstrar através da revisão de literatura as principais alterações ocorridas nas papilas gustativas dos idosos, com detecção dos gostos básicos doce, salgado, amargo e azedo, sendo essas fisiológicas ou de causas secundárias, com presença ou não, de patologias. Além de sua relação com a diminuição da qualidade de vida referente ao estado nutricional do indivíduo.

\section{REFERENCIAL TEÓRICO}

\subsection{A POPULAÇÃO E O ENVELHECIMENTO}

Sabe-se que o aumento da população idosa se dá devido o decréscimo da fertilidade e da mortalidade, além do crescimento da expectativa de vida. 0 processo de envelhecimento dos indivíduos é um fato existente na sociedade, essas situações repercutem modificações de alguns precursores do estado de saúde. Portanto, é missão das políticas de saúde colaborar para que mais indivíduos adquiram idades prósperas com o máximo estado de saúde possível, tornando a longevidade ativa e saudável, o principal propósito (ALTERMANN et al., 2011).

Fazzio (2012) afirmou nos seus achados que a velhice se localiza com regularidade, em mais menções aos aspectos de perdas e doenças do que sobre ganhos agregados ao envelhecimento, o que acontece é que devido às crenças de que perdas só sucedem-se na velhice e de que os ganhos são exclusivos dos períodos introdutivos do desenvolvimento, o que é um conceito equivocado, pois tanto perdas como ganhos acontecem em todas as fases da vida, por mais que no envelhecimento ocorram mais perdas do que ganhos devido às modificações próprias da idade.

Zanchim; Liberali e Coutinho (2013) relataram que o processo de envelhecer saudavelmente está diretamente ligado à manutenção do estado nutricional adequado e a nutrição equilibrada, no qual idosos mostram mais fragilidades a carências nutricionais e desnutrição, quando equiparados a outras faixas etárias. Devido a isso, modificações começam a ocorrer com o início do processo de envelhecimento, é comum os sentidos sofrerem diminuição do olfato e do paladar. Corroborando com Alves e Dantas (2014) tais fatores podem ocasionar diminuição da ingestão, monotonia alimentar, inapetência e desnutrição. Fica explícito que a avaliação do estado nutricional pode identificar prematuramente desvios nutricionais e assessorar os profissionais de saúde no tratamento, recuperação e promoção da saúde. 


\subsection{ALTERAÇÕES FISIOLÓGICAS NA TERCEIRA IDADE}

Tramontino et al., (2009) abordaram que com o aumento da expectativa de vida no mundo, surge a necessidade de se conhecer melhor as mudanças fisiológicas decorrentes do envelhecimento. E que com o passar dos anos, o corpo dá início naturalmente a algumas mudanças, que muitas vezes não são percebidas, mas que podem interferir na alimentação. As alterações que ocorrem no processo de envelhecimento de uma pessoa para outra são dependentes de fatores como estilo de vida, condições socioeconômicas e doenças crônicas. Dentre as principais alterações fisiológicas que podem afetar o comportamento alimentar dos idosos, evidenciam o decréscimo da sensibilidade gustativa para os gostos primários, a perda parcial ou total dos dentes, a desaceleração do metabolismo e a presença de doenças crônicas com consequente utilização de múltiplos medicamentos.

Chagas e Rocha (2012) relatam que as modificações naturais nos conjuntos dos mecanismos de defesa do organismo ou dificuldades na mastigação e deglutição podem exercer influência e deixar o idoso mais suscetível a complicações consequente do consumo de alimentos. No estudo de Silva; Becker e Couto, (2015) foram expostos que diversas modificações podem ser detectadas. Dentre essas abre um leque para a xerostomia ou secura da boca que é um distúrbio das glândulas salivares, resultante da idade avançada. Essa redução do fluxo salivar pode estar associada tanto a estados fisiológicos como patológicos, dentre eles a senescência. No idoso a disposição à secura da cavidade bucal está ligada à atrofia da mucosa oral e das glândulas salivares, que levará a repercussões ao processo de digestão dos alimentos o que dificulta a digestão oral e a deglutição sequente do bolo alimentar, podendo também ocorrer alterações na cavidade bucal, havendo perda do paladar.

Neto et al. (2011) observaram que o sentindo do paladar é adquirido através da gustação que é uma função dos corpúsculos gustativos, os botões gustativos descressem com o passar dos anos e as papilas gustativas começam a atrofiar, ressaltando também que o sentido do olfato contribui fortemente para a percepção do gosto, portanto é fundamental acentuar a sua relação com o paladar, e deixar claro que é necessário que ambos os sentidos estejam em condições adequadas, o olfato prejudicado impossibilita o sabor dos alimentos, o que se faz perder o apetite e o prazer em se alimentar.

As várias modificações funcionais e estruturais decorrentes do envelhecimento começam a desenvolver mais cedo assim que o organismo é exposto a patologias. Essas modificações merecem atenção especial pelos profissionais de saúde, é importante ressaltar que se deve conhecer as modificações fisiológicas e morfológicas para analisar e desenvolver estratégias que ajudem a minimizar os efeitos da senescência de forma que garanta a qualidade de vida positiva com idosos mais saudáveis e um final do ciclo de vida de uma forma independente (BRANDÃO et al., 2010).

\section{MATERIAL E MÉTODOS}

\subsection{TIPO DE ESTUDO}

0 delineamento metodológico deste estudo caracterizou-se por ser uma revisão bibliográfica de caráter exploratório descritivo e qualitativo, pois segundo Prodanov (2013), orienta conforme o ponto de vista dos objetivos como produção uma pesquisa científica e os diferentes tipos de estudo, no qual o mesmo justifica que um estudo desse porte tem por finalidade proporcionar informações em adição sobre o tema abordado, 
registros e descrições sobre os fatos observados sem interferências.

\subsection{COLETA DE DADOS}

Foi realizado um levantamento bibliográfico na literatura, com coleta em artigos científicos, monografias, dissertações, revistas científicas, anais de congressos nacionais e internacionais, além de sites de órgãos oficiais como o Ministério da Saúde através do Estatuto do Idoso. Para as buscas foram realizadas pesquisas nas bases de dados PubMed (Public Medline), SciELO (Scientific Electronic Library Online) e LILACS (Literatura Latino-americana em Ciências e Saúde) no período de Julho a Agosto de 2018, com ênfase nos últimos dez anos de publicação e os descritores utilizados para a coleta dos dados foram: alterações das papilas gustativas; envelhecimento e qualidade de vida; nutrição e alimentação do idoso; paladar e olfato.

\subsection{ANÁLISE DOS DADOS}

Após pesquisas minuciosas, a presente revisão bibliográfica reuniu um total de 50 artigos para sua elaboração e revisão final, depois dessa etapa, esses foram lidos na íntegra com intuito de verificação e constatação de critérios de inclusão e exclusão, tendo como produto a análise da abordagem teórica embasada em pesquisas realizadas no âmbito das alterações das papilas gustativas que ocorrem no processo de envelhecimento dos indivíduos em estado patológico ou não.

\section{RESULTADO E DISCUSSÃO}

\subsection{FATORES VINCULADOS À ALTERAÇÃO DO PALADAR}

Segundo Celich et al. (2010), com o processo de envelhecimento diversas são as causas que podem provocar diminuição da função gustativa em idades mais avançadas, de forma direta ou indireta, podem estar associados às modificações funcionais nos sistemas orgânicos, determinadas geneticamente e instigado pelo âmbito ambiental, social e de saúde, as quais podem implicar a capacidade psicológica e funcional, elevando a fragilidade do ser que envelhece. Paula; Fernandes e Souza (2014) julgaram que dentre os principais fatores pode-se salientar: higiene bucal, perdas dentarias, polifarmácia, tabagismo e o alcoolismo no qual são contribuintes consideravelmente nos distúrbios do paladar no público idoso.

Conforme Melo; Oliveira e Cavalcanti (2015), a precariedade da saúde bucal pode afetar a qualidade de vida dos idosos, aliado a isso existem os problemas de perda dentária, o que acarreta dificuldades de mastigação mesmo com uso de próteses, no qual segundo estudos apontam que idosos com próteses mastigam com menos efetividade ocasionando decrescimento de alimentos sólidos, portanto optam por alimentos líquidos e pastosos, o que diminui a alimpadura da língua durante o processo de mastigação e construção do bolo alimentar, avolumando a concentração da saburra lingual, obstruindo os botões gustativos impedindo a melhor palatabilidade.

De acordo com Pita et al. (2009), o realce gustativo depende também do processo correto de higiene bucal desse público, no qual os botões gustativos podem ser oclusos por resíduos alimentares impossibilitado que o idoso tenha melhor palatabilidade, especialmente aqueles que apresentam doenças crônicas como hipertensão e diabetes, 
no qual notarão com a adequada higiene bucal a melhora da gustação, prevenindo assim o consumo demasiado de alimentos mais salgados e açucarados.

Lopes et al. (2015) apontaram que outro fator importante é a polifarmácia, que é definida como o uso de muitos medicamentos simultaneamente, o que pode provocar modificações no paladar, diminuindo ou alterando a sensação do sabor nos alimentos. Alguns fármacos operam nos processos celulares encarregados pelo desenvolvimento dos sabores.

Segundo estudo de Vilpert (2017), as classes de fármacos mais empregados aos idosos são: benzodiazepínico, antiplaquetários, hipoglicemiantes orais, antihipertensivos, hipolipemiantes, antidepressivos, hormônio tireoidianos e antiácidos. A avaliação da revisão de literatura mostrou que os idosos apresentaram alteração ao sabor amargo, ácido e ponderou maior preponderância de alteração aos sabores salgado e doce.

Santos; Echeveste e Vidor (2013) destacaram que os sentidos do olfato e paladar são percepções sensoriais facilmente afetadas por agentes externos, dentre esses fatores encontra-se o tabagismo. 0 número de dependentes do tabaco está aumentando mesmo com o empenho para conter as taxas por meio de estratégias preventivas. Passa a ser do conhecimento de todos que o tabagismo produz efeito desfavorável na alimentação devido acometimentos olfatórios e gustativos provocados pela exposição constante a fumaça. Vale ressaltar que essas modificações ocorrem também em fumantes passivos pela inalação da fumaça em locais fechados.

É exibida na literatura a diferença na capacidade de reconhecimento gustativo de fumantes é inferior em relação à de não fumantes, o efeito de modificação na assimilação dos sabores encontrava-se com o tempo de tabagismo em longo prazo e não a um único cigarro. A falta de reconhecimento dá-se devido à comutação da forma, número e vascularização das papilas gustativas, o que influencia não somente na redução do sabor dos alimentos, mais faz alimentos apetitosos se tornem desagradáveis, devido ao incremento da percepção a substâncias amargas, salgadas e doces, baixa da impressão hedônica global e repulsão a substâncias doces (TEO et al., 2014).

E não menos importante, o hábito de ingerir bebida alcoólica é usado de maneira social, a fabricação e a ingestão de bebidas alcoólicas compõem uma transmissão oral de cultura de geração em geração presente em todos os públicos. Um estudo feito por Barbosa e Ferreira (2011) com dependentes de álcool em processo de reabilitação revelou que os participantes quando indagados sobre as alterações do paladar e olfato no decorrer do tempo ao consumo de álcool, relataram alterações nos dados sentidos. 0 consumo de álcool tem um efeito negativo sobre as necessidades ou imprescindibilidade do estado nutricional de um indivíduo, no qual esse efeito pode acontecer nas várias fases pelas quais os nutrientes e o álcool faz o processo no organismo, a começar pela ingestão até a excreção.

Diante de todos os fatores citados as diversas agressões sofridas pela boca no transcorrer ao longo da vida por patologias, medicamentos, drogas lícitas (álcool e cigarro) e problemas dentários decorrentes também da má higienização bucal ocasiona um decaimento fisiológico da sensibilidade aos sabores que provocarão maior ou menor severidade dessas alterações. Nesse ponto de vista, a literatura científica demonstra que alterações da sensibilidade gustativa permeiam o processo de envelhecimento com impacto potencial sobre o estado nutricional (PAULA et al., 2008; SILVA et al., 2017). 


\subsection{PATOLOGIAS QUE CAUSAM AS ALTERAÇÕES DAS PAPILAS GUSTATIVAS}

Já que ao envelhecer o corpo desenvolve alterações fisiológicas no organismo, substancialmente é frequente o aparecimento de doenças com o progresso dos anos. Nos achados de Silva (2011), a cavidade oral exibe modificações consequentes do processo de desgaste do corpo referente ao desempenho natural ou patológico de suas estruturas. Tais modificações são notadas como transcendente de manifestações de doenças sistêmicas, déficit nutricional, efeitos colaterais pelo uso abusivo ou por longo período de fármacos, refletido no funcionamento dos tecidos periodontais, na dentição, nas glândulas salivares e mucosas orais. Portanto, o processo de envelhecer se manifesta um desafio atual, que atinge tanto países desenvolvidos como os subdesenvolvidos, tornando-se um fato global e local.

É indispensável inteirar-se das diversas condições clínicas crônicas, das alterações fisiológicas que colaboram para o decrescimento da sensibilidade da percepção gustativa, e que apesar de camuflados nesta ocasião merecem total precaução diagnóstica e terapêutica já que o estado nutricional pode influenciar-se por inúmeras doenças, ressaltando que a falta de eficiência em manter um bom estado nutricional é corriqueiro entre o público idoso (CEOLIN e PINHEIRO, 2017).

Segundo Passos (2010), essas condições clínicas que possivelmente então relacionadas com as alterações palatáveis, realça as de natureza que afetam o estado nutricional, as de distúrbios do Sistema Nervoso Central e Endócrino, as doenças localizadas e outras condições que estão interligadas com essas modificações. A seguir o quadro adaptado demonstra o detalhamento de tais patologias conforme seu enquadramento.

\section{Quadro - Condições clínicas relacionadas com alterações palatáveis.}

\begin{tabular}{|l|l|}
\hline $\begin{array}{l}\text { Doenças que afetam o Estado } \\
\text { Nutricional }\end{array}$ & $\begin{array}{l}\text { Deficiências nutricionais (niacina, cobalamina e zinco); Queimadura } \\
\text { térmica; Câncer; Doenças hepáticas; Insuficiência renal crônica. }\end{array}$ \\
\hline $\begin{array}{l}\text { Distúrbios do Sistema Nervoso } \\
\text { Central }\end{array}$ & $\begin{array}{l}\text { Esclerose múltipla; Epilepsia; Paralisia facial; Doença de Alzheimer; } \\
\text { Trauma craniano; Dano ao nervo corda do tímpano; Doença de } \\
\text { Parkinson. }\end{array}$ \\
\hline Doença localizada & $\begin{array}{l}\text { Doença oral de Crohn; Hanseníase; Glossite; Xerostomia; Outros } \\
\text { distúrbios orais. }\end{array}$ \\
\hline $\begin{array}{l}\text { Distúrbios do Sistema } \\
\text { Endócrino }\end{array}$ & $\begin{array}{l}\text { Síndrome de Cushing; Hipotireoidismo; Diabetes Mellitus; } \\
\text { Cretinismo. }\end{array}$ \\
\hline Outras condições & $\begin{array}{l}\text { Infecções virais; Hipertensão arterial sistêmica; Laringectomia; } \\
\text { Asma; Rinite; Sinusite. }\end{array}$ \\
\hline
\end{tabular}

Fonte: Adaptada de Passos, 2010.

Silva; Galante e Manzi (2011) observaram que a maior parte de pacientes sujeitos ao tratamento de câncer sofre efeitos biológicos da radiação ionizante nas estruturas da cavidade bucal. Essas alterações acometem o desenvolvimento das papilas gustativas, no qual tais efeitos podem ser um pequeno retardo no crescimento e até a total destruição delas. A maioria submetida ao tratamento ocorre perda do paladar de forma rápida o que pode acometer-los pela perda parcial ou total do paladar e desenvolvimento de mucosite futuramente.

Nos estudos realizados por Schlosser e Ceolim (2012), no qual avaliaram que a qualidade de vida de pacientes em tratamento de câncer e seus efeitos colaterais, para um melhor planejamento de intervenções para diminuir os efeitos agudos e tardios que causam desconfortos, dificultam ou limitam suas atividades normais. 
Várias das modificações observadas na velhice interferem de modo negativo na alimentação e na qualidade de vida do idoso, quando se instala uma doença crônica em progresso, esse fator tende a acentuar. Tavares e Carvalho (2012) aduziram que na doença de Alzheimer as alterações funcionais e estruturais afetam o processo de mastigação e deglutição, o que acaba por modificar os hábitos alimentares, no qual há aumento pela preferência de alimentos líquidos, pastosos, moles e úmidos, desta maneira também há um aumento na quantidade de sal e/ou açúcar, como consequência do decréscimo do paladar.

Conforme Dias et al. (2016), os portadores de diabetes tem tendência a serem menos sensíveis ao sabor doce por desenvolverem alterações na sensibilidade gustativa. Essas modificações de decrescimento do paladar têm sido associadas à hipossalivação, xerostomia, a baixa produção da proteína gustina e à hiperglicemia com a presença entre os limiares do paladar e do nível de concentração de glicose no sangue. Através desse ponto de vista, a necessidade ao adicionamento de açúcar a preparação pode causar o consumo exagerado e ser fator contribuinte para o desenvolvimento ou agravamento da doença.

Estudo realizado por Correia (2008), demonstrou que a hipertensão é sempre baseada em mudanças de estilo de vida, principalmente, no que se refere à alimentação, e que o principal fator para os benefícios do tratamento ou prevenção é que o indivíduo deve se submeter a mudanças como a redução do sal, porém o autor ressalta que idosos tendem a adicionar mais sal que o necessário em suas preparações para que sejam capazes de sentir o gosto, no qual devido o envelhecer e os medicamentos tendem a modificações na percepção do sabor. 0 que induz não somente ao agravamento da patologia com elevação significativa, mais ao surgimento de hipertensão arterial.

Em suma, a qualidade de vida dos idosos é fortemente influenciada pelo envelhecimento dos vários sentidos, uma vez que permeia a relação do indivíduo com o mundo, influenciando o padrão de conduta do idoso, o paladar é o mais importante no ato de se alimentar, e várias são as condições clínicas que o afetam, essas doenças representam um considerável problema de saúde, pois atua na baixa qualidade de vida e limita o idoso, portanto esses dados merecem destaque por causarem alterações no paladar o que interfere diretamente no estado nutricional da população longeva (SILVA e CATÃO, 2012).

\subsection{ESTADO NUTRICIONAL DO IDOSO E CONDUTA DO PROFISSIONAL NUTRICIONISTA}

A população longeva apresenta modificações no paladar próprias da idade. De acordo com Silva et al. (2015), em relação ao paladar tanto o prazer à alimentação quanto o consumo é afetado, a avaliação nutricional do idoso mostra problemas relacionados por alterações estruturais e funcionais. No qual a menor vontade em se alimentar causada pela baixa da sensibilidade gustativa juntamente com receptores olfatórios determinam risco de desnutrição. Fatores como problemas bucais tal como a Hipogeusia e outras características relacionadas também atinge o interesse ao ato de se alimentar, sendo também um dos determinantes e fator a déficits nutricionais.

Gonzaga et al., (2015) exibem que o público idoso carece de uma assistência diversificada, visto que, com o passar dos anos, os mesmos sofrem modificações psicológicas e físicas e que procuram respostas adaptativas em relação às mais novas 
situações exigidas pelo próprio organismo e pela sociedade na qual estão incorporados. São diante desse contexto que o profissional de saúde manifesta-se. No qual, sua conduta será na proposta de assistência ao idoso, e será traspassada pela empatia, escuta e melhor forma que propicie integração social do idoso.

Pereira; Spyrides e Andrade (2016) esclareceram em seu estudo que o paladar tem relevância importante para o bem-estar do indivíduo na terceira idade, suas modificações podem trazer grandes prejuízos no controle de dietas com limitações referentes à seleção e ingestão de alimentos, essa sensibilidade gustativa apresenta dificuldades para contemplar o sabor do alimento e consequentemente resulta na nutrição do idoso, portanto, é de suma importância o diagnostico nutricional juntamente com os fatores, mesmo sendo um processo complexo mais que é essencial para o profissional de saúde intervir.

Oliveira, Delgado e Brescovici (2014) relataram que mais da metade dos indivíduos entrevistados em seu estudo consolidou dispor a necessidade de incrementar com açúcar, sal e outros temperos a comida para alcançar o sabor que seja agradável ao paladar, o que o faz consumir abusivamente, sabe-se também que a condição dentária afeta no processo de alimentação, atingindo a função do processo mecânico da mastigação, o que acomete o preparo do bolo alimentar dificultando a deglutição, circunstância que por vezes provoca desconforto no idoso, decréscimo da ingestão de alimentos sólidos e transição para alimentos macios o que gera perda do prazer em se alimentar.

Camargo et al., (2015) apontaram a insatisfação dos idosos com relação ao sabor das refeições ofertadas, e constatado que a apreciação da alimentação está relacionada a atributos presentes no alimento, como sabor e tempero. Frente a isso, os autores alertam ainda quanto à monotonia no planejamento dos cardápios, salientando que as refeições oferecidas devem contemplar as preferências alimentares dos idosos e os princípios de uma alimentação saudável, a fim de que não ocorra o decréscimo do apetite, proporcionando um estado nutricional equilibrado e melhor qualidade de vida.

É importante que o profissional nutricionista oriente o idoso a comer devagar, mastigando e triturando bem os alimentos, lembrando-o que a digestão inicia pela boca. Portanto, o processo de mastigação feito corretamente estimula a produção da saliva o que proporciona a melhor percepção do sabor, os cuidados de higiene bucal também ajudam na melhora do sabor evitando assim o exagero nos condimentos. A utilização de temperos naturais como cebola, alho, cheiro verde e ervas, pode auxiliar a conter o sal no preparo dos alimentos, até se adaptares ao sabor dos alimentos com pouco sal na preparação. Tais recomendações servem para despertar a vontade de saborear refeições saudáveis e que concebam satisfação ao serem consumidas, pois o feito de se alimentar deve conferir aprazimento.

\section{CONCLUSÃO}

Diante da análise bibliográfica, todos os fatores mencionados dos distúrbios do paladar merecem maior autocuidado quando se trata da terceira idade, no qual essa nova realidade tem provocado amplo impacto no sistema de saúde, principalmente porque os modelos tradicionais de assistência a terceira idade mostram-se ineficientes, o que abre um leque para desenvolvimento de programas que visem à promoção e prevenção de saúde no processo de envelhecimento, proporcionando a melhora da 
qualidade de vida.

Dessa forma, o acompanhamento envolvendo uma equipe multidisciplinar e principalmente o nutricionista com relação à alimentação, através da identificação de possíveis riscos ou de erros alimentares já instalados e a consequente orientação para uma nutrição adequada, adaptada às condições de cada indivíduo idoso, devem ser constantes, para que a vida longa, desejada por todos, seja prazerosa e não onerosa. Concluímos que novos estudos são necessários para uma avaliação mais precisa, pois o assunto abordado ainda é escasso de material científico o que dificulta uma melhor avaliação desse público idoso.

\section{REFERÊNCIAS}

ALTERMANN, C. S.; BATISTA, C. P.; PEREIRA, L. C.; BEliTZ, T. G.; BLUMKE, A. C.; MATTOS, K. M. Estado nutricional e patologias em idosos usuários do serviço de nutrição de uma unidade básica. Revista Contexto \& Saúde, v. 11, n. 20, p. 943-946, 2011. Disponível em: $<14$

https://www.revistas.unijui.edu.br/index.php/contextoesaude/article/view/1701 >. Acesso em: 12.03.2021.

ALVES, L. M. T.; DANTAS, R. O. Percepção de sabores em pessoas normais. GED gastroenterol.endosc. dig., v. 33, n. 3, p. 102-105, 2014. Disponível em: < http://files.bvs.br/upload/S/0101-7772/2014/v33n3/a5092.pdf >. Acesso em: 25 Ago. 2018.

BARBOSA, C. D.; FERREIRA, C. C. D. 0 papel da nutrição no processo reabilitatório de dependentes

de álcool. Cadernos UniFOA, v. 6, n. 1, p. 89-101, 2011. Disponível em: <

http://revistas.unifoa.edu.br/index.php/cadernos/article/view/1225/1115 >. Acesso em: 10.30.2021.

BARBOSA, R. G. B.; FERRIOLLI, E.; MORIGUTI, J. C.; NOGUEIRA, C. B.; NOBRE, F.; UETA, J.; LIMA, N. K. C. Adesão ao Tratamento e Controle da Pressão Arterial em Idosos com Hipertensão. Arq. Bras. Cardiol., v. 99, n. 1, p. 636-641, 2012. Disponível em: <

http://www.scielo.br/pdf/abc/v99n1/aop05112.pdf >. Acesso em: 20.02.2021

BRANDÃO, A. F.; VARGAS, V. S.; GOMES, G. C.; PELZER, M. R.; LUNARDI, V. L. Educação Nutricional para idosos e seus cuidadores no contexto da educação em saúde. VITTALLE, Rio Grande, v. 22, n. 1, p. 27-37, 2010. Disponível em: < https://periodicos.furg.br/vittalle/article/view/1293/1080 >. Acesso em: 10.01.2021.

BRASIL, MINISTÉRIO DA SAÚDE, SECRETARIA DE ATENÇÃO À SAÚDE, DEPARTAMENTO DE AÇÕES PROGRAMÁTICAS E ESTRATÉGICAS. Estatuto do idoso. 3. ed., Brasília, 2013, 70 p. Disponível em: < http://bvsms.saude.gov.br/bvs/publicacoes/estatuto_idoso_3edicao.pdf >. Acesso em: 11.02.2021. 
CAMARGOS, M. C. S.; NASCIMENTO, G. W. C.; NASCIMEMTO, D. I. C.; MACHADO, C. J. Aspectos relacionados à alimentação em Instituições de Longa Permanência para Idosos em Minas Gerais. Cad. Saúde Colet., Rio de Janeiro, v. 23, n. 1, p. 38-43, 2015. Disponível em: <http://www.scielo.br/pdf/cadsc/v23n1/1414-462X-cadsc-23-01-00038.pdf >. Acesso em: 01.02.2021.

CATÃO, M. H. C. V.; XAVIER, A. F. C.; PINTO, T. C. A. O impacto das alterações do sistema estomatognático na nutrição do idoso. Revista Brasileira de Ciências da Saúde, ano 9, n. 29, p. 73-78, 2011. Disponível em: http://seer.uscs.edu.br/index.php/revista_ciencias_saude/article/view/1349/1067

>. Acesso em: 1.02.2021.

CELICH, K. L. S.; CREUTZBERG, M.; GOLDIM, J. R.; GOMES, I. Envelhecimento com qualidade de vida: A percepção de idosos participantes de grupos de terceira idade. Rev. Min. Enferm., v. 14, n. 2, p. 226-232, 2010. Disponível em: < http://www.reme.org.br/artigo/detalhes/110\# >. Acesso em: 02.03.2021.

CEOLIN, J.; PINHEIRO, T. L. F. Sensibilidade gustativa em idosos: uma revisão narrativa. Pajar, v. 5, n. 2, p. 78-84, 2017. Disponível em: < http://revistaseletronicas.pucrs.br/ojs/index.php/pajar/article/view/28259/16380 >. Acesso em: 10.02.2021.

COELHO, H. D. S.; GRANATO, L. Avaliação dos limiares de detecção do gosto salgado em idosos. J Health Sci Inst., v. 32, n. 4, p. 413-418, 2014. Disponível em: <https://www.unip.br/presencial/comunicacao/publicacoes/ics/edicoes/2014/04_out dez/

V32_n4_2014_p413a418.pdf >. Acesso em: 09.03.2021.

CORREIA, J. H. C. Redução do paladar em idosos para os gostos doce e salgado. 2008. 26 f. Monografia (Especialização em Gastronomia e Saúde) - Centro de Excelência em Turismo, Universidade de Brasília, Brasília. Disponível em: < http://bdm.unb.br/bitstream/10483/322/1/2008_JoanaHolandaCavalcantiCorreia.pdf >. Acesso em: 10.02.2021.

CRUZ, D. T.; CAETANO, V. C.; LEITE, I. C. G. Envelhecimento populacional e bases legais da atenção à saúde do idoso. Cad. Saúde Colet., Rio de Janeiro, v. 18, n. 4, p. 500-508, 2010. Disponível em: <http://www.cadernos.iesc.ufrj.br/cadernos/images/csc/2010_4/artigos/CSC_v18n4_5 00-508.pdf >. Acesso em: 06.02.2021.

CHAGAS, A. M.; ROCHA, E. D. Aspectos fisiológicos do envelhecimento e contribuição da Odontologia na saúde do idoso. Rev. bras. odontol., Rio de Janeiro, v. 69, n. 1, p. 94-96, 2012. Disponível em: < http://revodonto.bvsalud.org/pdf/rbo/v69n1/a21v69n1.pdf >. Acesso em: 08.01.2021.

DIAS, V. R.; BRAZIL, J. M.; ALMEIDA, J. A. R.; SILVA, C. S.; MILAGRES, M. P. Avaliação da percepção sensorial ao gosto doce em pessoas com Diabetes Mellitus tipo2. Rev. Rene, v. 17, n. 4, p. 483-489, 2016. Disponível em: < http://periodicos.ufc.br/rene/article/view/4937/3638 >. Acesso em: 07.02.2021. 
FAZZIO, D. M. G. Envelhecimento e qualidade de vida - Uma abordagem nutricional e alimentar. Revisa, v. 1, n. 1, p. 76-88, 2012. Disponível em: $<$ http://revistafacesa.senaaires.com.br/index.php/revisa/article/view/15/12 >. Acesso em: 03.02.2021.

FRANCISCO, P. M. S. B.; BELON, A. P.; BARROS, M. B. A.; ALVES, M. C. G. P.; GOLDBAUM, M.; CESAR, C. L. G. Diabetes auto-referido em idosos: prevalência, fatores associados e práticas de controle. Cad. Saúde Pública, Rio de Janeiro, v. 26, n. 1, p. 175-184, 2010. Disponível em: < http://www.scielo.br/pdf/csp/v26n1/18 >. Acesso em: 03.02.2021.

GONZAGA, B. O.; BARROS, M. S.; NÓBREGA, N. B. G.; OLIVEIRA, R. P. P.; CLEMENTINO, F. S. As contribuições das políticas de saúde na promoção de uma assistência humanizada aos idosos: Uma revisão de literatura. Revista Saúde e Ciência online, v. 4, n. 3, p. 79-88, 2015. Disponível em: < http://www.ufcg.edu.br/revistasaudeeciencia/index.php/RSCUFCG/article/view/359/238 >. Acesso em: 01.01.2021.

GUSMÃO, J. L.; GINANI, G. F.; SILVA, G. V.; ORTEGA, K. C.; JUNIOR, D. M. Adesão ao tratamento em hipertensão arterial sistólica isolada. Rev. Bras. Hipertens., v. 16, n. 1, p. 38-43, 2009. Disponível em: < http://departamentos.cardiol.br/dha/revista/16-1/11adesao.pdf >. Acesso em: 11.01.2021.

LEBRÃO, M. L. Epidemiologia do envelhecimento. Bol. Inst. Saúde (Impr.), n. 47, p. 23-26, 2009. Disponível em: < http://periodicos.ses.sp.bvs.br/pdf/bis/n47/a05_bisn47.pdf >. Acesso em: 1.02.2021.

LOPES, A. C. F.; PEREIRA, C. S. S.; FERNANDES, F. L.; VALENTE, L. C.; VALADÃO, F. A.; ABREU, M. N. S.; MOTTA, P. G. Prevalência de alterações gustativas em idosos em uso crônico de fármacos. Geriatr. Gerontol. and Aging, v. 9, n. 4, p. 132-137, 2015. Disponível em: < https://sbgg.org.br//wp-content/uploads/2014/10/1450709733_GG_v9n4.pdf >. Acesso em: 20.01.2021.

LOUREIRO, M. H. V. S. Validação do "Mini-Nutricional Assessement" em Idosos. 2008. 135 f. Dissertação (Mestrado em Nutrição Clínica) - Faculdade de Medicina, Universidade de Coimbra, Coimbra. Disponível em: < https://estudogeral.sib.uc.pt/bitstream/10316/10439/1/TESE\%20MHVSL.pdf

>. Acesso em: 1.03.2021.

MAGALHÃES, L. M. R. Relação entre saúde oral e nutrição do idoso. 2011. 57 f. Projecto de graduação (Mestrado Integrado em Medicina Dentária) - Universidade Fernando Pessoa, Porto. Disponível em: < https://bdigital.ufp.pt/bitstream/10284/2402/3/T.pdf > . Acesso em: 10.02.2021.

MELO, G. A.; OLIVEIRA, S. R. V. A.; CAVALCANTI, M. S. Nutrição e envelhecimento: Fatores que interferem o consumo alimentar do idoso e sua qualidade de vida. In: CONGRESSO INTERNACIONAL DE ENVELHECIMENTO HUMANO, 4., 2015, Campina Grande. Anais... Campina Grande: Faculdade Maurício de Nassau, 2015. Disponível em: <https://editorarealize.com.br/revistas/cieh/trabalhos/TRABALHO_EV040_MD4_SA15_ ID2941_13082015184630.pdf > . Acesso em: 05.01.2021.

MONTEIRO, M. A. M. Percepção sensorial dos alimentos em idosos. Revista Espaço para a 
Saúde, Londrina, v. 10, n. 2, p. 34-42, 2009. Disponível em: < http://bases.bireme.br/cgibin/wxislind.exe/iah/online/?IsisScript=iah/iah.xis\&src=goo

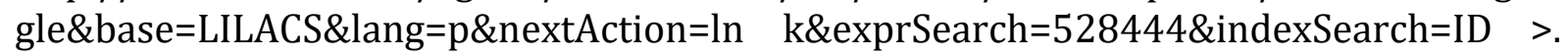
Acesso em: 02.01.2021.

NETO, F. X. P.; TARGINO, M. N.; PEIXOTO, V. S.; ALCÂNTARA, F. B.; JESUS, C.C.; ARAÚJO, D. C.; FILHO, E. F. L. M. Anormalidades sensoriais: Olfato e paladar. Arq. Int. Otorrinolaringol., São Paulo, v. 15, n. 3, p. 350-358, 2011. Disponível em: < http://www.scielo.br/pdf/aio/v15n3/v15n3a14.pdf >. Acesso em: 10.02.2021.

OLIVEIRA, B. S.; DELGADO, S. E.; BRESCOVICI, S. M. Alterações das funções de mastigação e deglutição no processo de alimentação de idosos institucionalizados. Rev. Bras. Geriatr. Gerontol., Rio de Janeiro, v. 17, n. 3, p. 575-587, 2014. Disponível em: < www.scielo.br/pdf/rbgg/v17n3/1809-9823- rbgg-17-03-00575.pdf >. Acesso em:02.02.2021.

PAULA, A. K. C.; FERNANDES, F. B.; SOUZA, I. F. Fatores associados às alterações do equilíbrio no idoso e a intervenção da terapia ocupacional. Revista Cientifica da Escola de Saúde UNP., v. 3, $\mathrm{n}$ 2, 2014. Disponível em: < https://repositorio.unp.br/index.php/catussaba/article/view/601 >. Acesso em: 01.02.2021.

PAULA, R. S.; COLARES, F. C. J.; TOLEDO, J. O.; NÓBREGA, O. T. Alterações gustativas no envelhecimento. Revista Kairós, São Paulo, v. 11, n. 1, p. 217-235, 2008. Disponível em: < https://revistas.pucsp.br/index.php/kairos/article/view/2518/1603 >. Acesso em: 1.02.2021.

PARAHYBA, M. I.; VERAS, R. Diferenciais sociodemográficos no declínio funcional em mobilidade física entre os idosos no Brasil. Ciência \& Saúde Coletiva, v. 13, n. 4, p. 12571264, 2008. Disponível em: < www.scielo.br/pdf/csc/v13n4/22.pdf >. Acesso em: 11.03.2021.

PASSOS, D. R. Avaliação do paladar de idosos e sua relação com o estado nutricional. 2010. 54 f. Trabalho de Conclusão de Curso (Bacharel em Nutrição) - Faculdade de Medicina, Universidade Federal de Rio Grande do Sul, Porto Alegre. Disponível em: <

https://lume.ufrgs.br/bitstream/handle/10183/28186/000768967.pdf >. Acesso em: 10.02.2021.

PASSOS, J. G.; GUIMARÃES, L. C.; VICTORIA, M. C. M. Avaliação da percepção gustativa em idosos para os gostos básicos, doce e salgado, em comparação a jovens adultos. J Health Sci. Inst., v. 34, n. 1, p. 29-32, 2016. Disponível em: < https://www.unip.br/presencial/comunicacao/publicacoes/ics/edicoes/2016/01_janm $\operatorname{ar} /$

V34_n1_2016_p29a32.pdf >. Acesso em: 25.02.2021

PEREIRA, I. F. S.; SPYRIDES, M. H. C.; ANDRADE, L. M. B. Estado nutricional de idosos no Brasil: uma abordagem multinível. Cad. Saúde Pública, Rio de Janeiro, v. 32, n. 5, p. 1-12, 2016. Disponível em: < http://www.scielo.br/pdf/csp/v32n5/1678-4464-csp-32-05e00178814.pdf >. Acesso em: 25.01.2021. 
PITA, M. S.; ANCHIETA, R. B.; JÚNIOR, M. M.; ARCHANGELO, C. M.; SILVA, E. M. M.;BARBOSA, D. B.; ZUIM, P. R. J. Cuidados com a higiene bucal do idoso: orientações, materiais e métodos utilizados. Revista UNINGÁ, Maringá - PR, v. 22, n. 1, p.161-178, 2009. Disponível em: <http://revista.uninga.br/index.php/uninga/article/view/854 >. Acesso em: 13.02.2021.

PRODANOV, C. C.; FREITAS, E. C. Metodologia do Trabalho Científico: Métodos e Técnicas da Pesquisa e do Trabalho Acadêmico. 2. ed. Universidade FEEVALE: FEEVALE, 2013, p. 51-72. Disponível em: < http://www.feevale.br/Comum/midias/8807f05a-14d0-4d5bb1ad-1538f3aef538/Ebook\%

20Metodologia\%20do\%20Trabalho\%20Cientifico.pdf >. Acesso em: 13.02.2021.

SANTOS, A. C. O.; MACHADO, M. M. O.; LEITE, E. M.; Envelhecimento e alterações do estado nutricional. Geriatria \& Gerontologia, v. 4, n. 3, p. 168-175, 2010. Disponível em: <https://sbgg.org.br//wp-content/uploads/2014/10/2010-4.pdf >. Acesso em: 06.03.2021.

SANTOS, K. W.; ECHEVESTE, S. S.; VIDOR, D. C. G. M. Influência da percepção olfativa e gustativa na fase oral da deglutição de indivíduos tabagistas. CoDAS, v. 26, n. 1, p. 68-75, 2013. Disponível em: < http://www.scielo.br/pdf/codas/v26n1/pt_2317-1782-codas26-01-00068.pdf > . Acess0. 01.03.2021.

SILVA, A. D. L.; CATÃO, M. H. C. V. Doenças sistêmicas em idosos não institucionalizados. HU Revista, Juiz de Fora, v. 37, n. 3, p. 299-303, 2012. Disponível em: <https://hurevista.ufjf.emnuvens.com.br/hurevista/article/viewFile/1381/571 >. Acesso em: 07.01.2021. 


\section{Capítulo 14}

O processamento da polpa de açaí em uma feira-livre na cidade de Manaus-AM: Estudo de caso

\section{Samuel Moreira Lima}

\section{Francimeire Gomes Pinheiro}

\section{Sabrina da Fonseca Meireles}

Resumo: Os subprodutos do açaí têm chamado atenção nacional e internacional devido aos seus benefícios nutricionais e terapêuticos. Nos últimos anos, este alimento tem sido associado ao aumento de casos de doença de Chagas aguda na região Norte do Brasil. Diante dessa problemática, foi realizado um estudo de caso, sobre os procedimentos adotados no preparo do vinho de açaí em uma feira livre da cidade Manaus, Amazonas. Para tanto, pesquisas sobre o tema foram feitas, assim como uma visita ao local de produção da bebida. Observou-se várias etapas incorretas no processo de preparo da bebida, desde o recebimento até o acondicionamento do produto para comercialização. Estes dados, sinalizam a necessidade de constantes vistorias aos estabelecimentos de produção e vendas de açaí, para averiguar o cumprimento de regulamentos técnicos de boas práticas de fabricação desse alimento, visando a sua inocuidade como um fator protetivo contra a doença de Chagas.

Palavras-chave: Açaizeiro, Doença de Chagas, Epidemiologia, Nutrição, Polpa, Vinho de açaí. 


\section{INTRODUCĈ̃O}

0 açaizeiro (Euterpe oleracea Mart.) é uma palmeira tropical nativa da América Central e do Sul, com predominância na região amazônica. É um fruto de notável importância nutricional que tem ganhado atenção nacional e internacional, devido aos seus benefícios nutricionais e terapêuticos, relacionados a sua alta capacidade antioxidante e composição fitoquímica (BERNAUD e FUNCHAL, 2011). Além disso, o açaizeiro é a principal fonte de matéria prima para a agroindústria de palmito no Brasil (EMBRAPA, 2012).

0 açaí é apreciado nas formas de geleia, licor, polpa congelada, xarope, pó, creme e sorvetes. No mercado brasileiro, o fruto é consumido com finalidade de bebida energética; já no mercado externo, como uma bebida exótica (DARNET et al., 2011; YAMAGUCHI et al., 2015). Na região norte do país, o açaí está presente no consumo diário da população, em forma de bebida, sendo comum sua comercialização em mercados e feiras livres.

A coleta e o acondicionamento do fruto requerem cuidado no manuseio, pois, o açaí é altamente perecível devido a sua elevada carga microbiana (SOUSA et al., 1999). A conservação da polpa de açaí é feita pelo processo de congelamento (ROGEZ, 2000). No entanto, a contaminação do açaí por protozoários, como o Trypanossoma cruzi ocorrido na região amazônica (ANVISA, 2008) tem sinalizado a necessidade de estratégias para garantir a inocuidade desse fruto, mantendo suas propriedades sensoriais e nutricionais. Neste sentido, analisou-se a rotina de preparo e manuseio de polpas de açaí em uma feira livre de Manaus, AM.

\section{REFERENCIAL TEÓRICO}

\subsection{AÇAÍ COMO FONTE ALIMENTAR}

0 fruto do açaizeiro apresenta característica globosa (1 a $2 \mathrm{~cm}$ de diâmetro); peso médio de 1,5 grama; dependendo do tipo e da maturação, o epicarpo é roxo ou verde (Figura 1). Na região amazônica, o açaí é considerado um dos frutos mais nutritivos, constituído por ácidos graxos mono e poliinsaturados, saturados, ácidos graxos linoleico, palmítico, aminoácidos, vitaminas do complexo B, minerais, cálcio, potássio, magnésio e ferro, além de fibras como as lignanas e antioxidantes (MENEZES et al., 2008). 0 fruto também apresenta elevado teor de compostos fenólicos, como os pigmentos antocianinas e outros flavonoides (ROGEZ, 2000; ROCHA et al., 2015).

Figura 1. Representação do cacho de açaí.

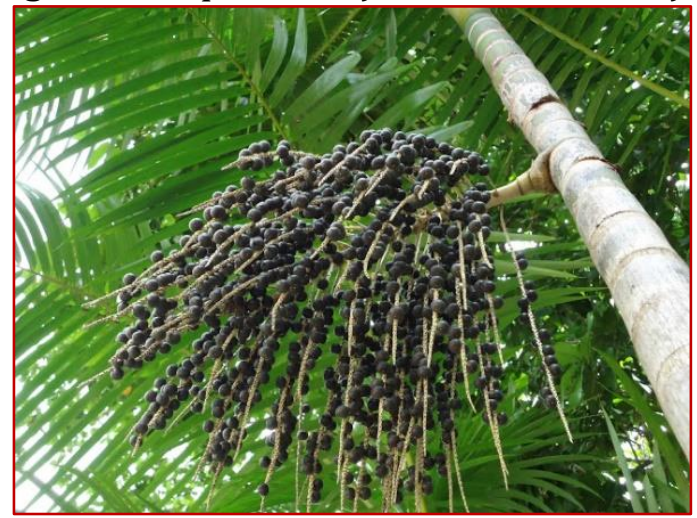

Fonte: FURTADO, 2011 
A comercialização dos frutos do açaizeiro perfaz a renda de famílias residentes da região amazônica e seu processamento, gera além da semente, outros subprodutos (Tabela 1). Outra aplicação importante, é na medicina, prevenindo o desenvolvimento de doenças crônicas, como de hipertensão, disfunção endotelial e alterações estruturais vasculares, por apresentar um potente efeito vasodilatador dependente do endotélio e da ação antioxidante e anti-hipertensiva (ROCHA et al., 2008; COSTA et al., 2012). Além de proteger os eritrócitos humanos e as células polimorfonucleares contra o estresse oxidativo (HONZEL et al., 2008; JENSEN et al., 2008).

Tabela 1. Relação de utilidades dos produtos e subprodutos do açaizeiro.

\begin{tabular}{|c|c|}
\hline Componentes & Formas de uso \\
\hline Frutos & $\begin{array}{l}\text { Suco, creme, sorvete, licor, geleia, mingau, curtimento de couro, adubo } \\
\text { orgânico. produção de álcool, carburante e antidiarreico }\end{array}$ \\
\hline Palmito & Picles, salada, recheio, creme e ração animal \\
\hline Folhas & $\begin{array}{l}\text { Cobertura de casa, parede, cesto, tapete, chapéu, esteira, adorno caseiro, } \\
\text { celulose, ração animal, adubo orgânico, cobertura morta e sombreamento de } \\
\text { sementeiras e plantas }\end{array}$ \\
\hline Estipe (caule) & Construção de casa, ponte, cerca, curral, lenha, celulose e isolamento elétrico \\
\hline Cacho & Vassoura e adubo orgânico \\
\hline Raízes & Vermífugo \\
\hline
\end{tabular}

Fonte: Destaque Amazônia, órgão de divulgação do Museu Paraense Emílio Goeldi, 1985; EMBRAPA, 1985.

\subsection{AÇAÍ E DOENÇA DE CHAGAS}

A doença de Chagas representa uma condição infecciosa com fase aguda ou crônica, classificada como enfermidade negligenciada pela Organização Mundial da Saúde (WHO, 2012; 2013). Trata-se de uma doença protozoária, causada pelo T. cruzi, transmitida principalmente pela picada do inseto conhecido como barbeiro ao ser humano, podendo ocorrer pelas vias: vetorial, transfusional, congênita, acidentes em laboratórios e via oral. Atualmente, as formas de transmissão relacionadas com o consumo de alimentos vêm recebendo destaque.

A transmissão por via oral geralmente está associada a surtos, mas também pode ocorrer em casos isolados, apresentando-se no ciclo enzoótico primitivo deste parasita, por meio da ingestão por mamíferos susceptíveis de vetores e reservatórios infectados (OPAS, 2009). No caso do homem, esta transmissão ocorre de maneira esporádica e circunstancial, pela ingesta alimentos contaminados com o parasita, principalmente a partir de triatomíneos ou de suas dejeções (DIAS e AMAT0, 2011).

A transmissão por caldo de cana contaminado pelo Trypanossoma foi descrita inicialmente, ocasionada pela maceração dos barbeiros no preparo do alimento ou pela contaminação destes pelas fezes de animais infectados (SHIKANAI-YASUDA e CARVALHO, 2012). De maneira semelhante, a transmissão por açaí contaminado já foi relatada e recebe grande destaque, segundo o Ministério da Saúde (2015), visto que, até mesmo após a filtração da polpa da fruta e armazenamento no congelador, o parasita se mantém viável e com capacidade de transmitir a doença (PASSOS et al., 2012). 


\section{MATERIAL E MÉTODOS}

Este estudo de caso é sobre os procedimentos utilizados na fabricação do vinho de açaí em uma feira livre da cidade de Manaus. Para tanto, primeiramente, foi realizado uma intensa busca na literatura científica sobre as metodologias preconizadas pelos órgãos de vigilância e fiscalização em saúde, para o preparo manual e industrial do subproduto do açaí - o vinho. Após munição de conhecimentos técnicos sobre o tema, realizou-se uma visita ao estabelecimento de preparo e venda de açaí, para acompanhamento da rotina. Durante a observação dos processos, utilizou-se um questionário norteador, contendo etapas desde o recebimento dos frutos até o armazenamento, a saber: (1) como os frutos são recebidos pelo proprietário; (2) como se dá o manuseio dos frutos; (3) como é realizada a higienização; (4) como a polpa é obtida; (5) como o vinho é envasado e; (6) como é feito o armazenamento do produto.

\section{RESULTADOS E DISCUSSÃO}

\subsection{RELATÓRIO DO ESTUDO DE CASO}

Após buscas na literatura sobre as metodologias de processamento do açaí, optou-se por seguir os procedimentos de triagem e acondicionamento do açaí descritos no manual intitulado "Açaí Congelado", elaborado por Valéria Saldanha Bezerra, em parceria com a Empresa Brasileira de Pesquisa Agropecuária - EMBRAPA, Amapá e Ministério da Agricultura, Pecuária e Abastecimento - MAPE (2007).

Considerando o vinho de açaí um dos principais componentes da dieta da população amazônica e sua perecibilidade que não resiste mais do que 72 horas, mesmo em ambiente refrigerado, comprometendo a sua comercialização e, a sua escassez na entressafra, etapas do processamento de açaí congelado foram preconizados (Figura 2).

Figura 1. Etapas do processo de produção de açaí congelado.

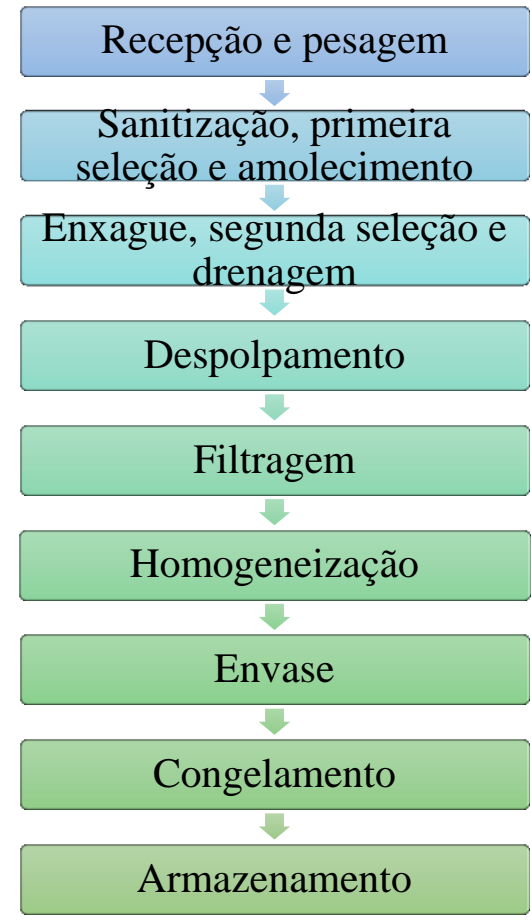

Fonte: BEZERRA, 2007. 
A realização dos procedimentos supracitados para a agroindústria de açaí congelado, permite eliminar, tanto quanto possível, os riscos de contaminação de diferentes origens, garantindo, assim, a qualidade do produto e a segurança à saúde do consumidor (BEZERRA, 2007).

\subsubsection{INFORMAÇÕES GERAIS DO ESTABELECIMENTO}

A observação da rotina de processamento e acondicionamento do açaí foi realizada em um ponto comercial, localizado na feira livre do bairro Zumbi dos Palmares, zona leste da cidade de Manaus, Amazonas. Durante a observação dos procedimentos, utilizou-se um questionário norteador, contendo etapas desde o recebimento dos frutos ao armazenamento, descrito no item 3.

\subsubsection{OBSERVAÇÃO DO PROCESSAMENTO DO AÇAÍ}

Na primeira etapa, constituída pela entrega dos frutos ao proprietário do estabelecimento, observou-se que os frutos chegavam em sacos de ráfia. Após o recebimento, os frutos foram dispensados em caixotes de plástico dispostos ao chão do estabelecimento (Figura 3A), contendo água, em desacordo com as normas da Agência Nacional de Vigilância Sanitária - ANVISA (2008) que estabelece a necessidade de um local de armazenamento protegido, limpo e organizado para a conservação dos produtos, que devem ser guardados em recipientes impermeáveis, resistentes e laváveis, não podendo ter contato direto com o piso.

A obtenção da polpa de açaí foi realizada com auxílio do maquinário, denominado "batedor de açaí" (Figura 3B), onde os frutos foram colocados no equipamento para despolpamento mecânico. O líquido resultante foi transferido para vasilhames de plástico (Figura 3C), os quais foram filtrados e envasados em sacolas de plástico transparente manualmente, por meio de um copo metálico (Figuras 3C e E). Durante a transferência do líquido recém processado para as embalagens, não foi observado o uso de um avental, touca, botas de plástico, luvas e máscara descartáveis.

Após o despolpamento dos frutos, ainda foi possível notar a adição de uma substância à polpa, um corante alimentício (Figura 3D), segundo relato do proprietário. De acordo com o Regulamento Técnico para fixação de padrões de identidade e qualidade para polpas de frutas, as polpas são produtos que devem conter apenas o despolpamento das frutas e o acréscimo de água nas devidas proporções. A adição de qualquer outra substância, além do ácido cítrico (para produtos pasteurizados), é considerada como adulteração (BRASIL, 2000. apud PANTOJA, 2017, p.12).

Após a finalização da etapa de embalagem, alguns produtos foram armazenados dentro de uma caixa de isopor com gelo, outros foram colocados para exposição sobre a caixa (Figura $3 \mathrm{~F}$ ). Ademais, não foi observado nas embalagens etiquetas contendo identificação de informações importantes sobre o produto, como o registro e data de validade. 
Figura 3. Representação das etapas (A-F) do processamento manual de açaí em uma feira livre.

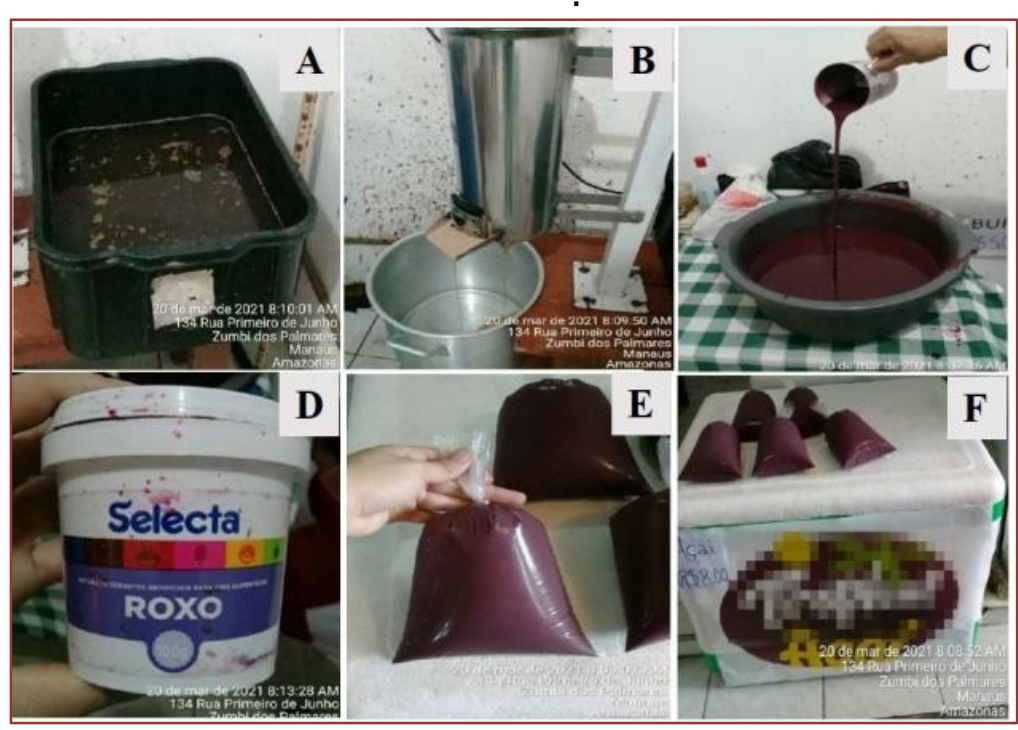

Fonte: LIMA, 2021.

0 acondicionamento do produto deve seguir as normas estabelecidas pela ANVISA, pois o processo inadequado de produção da polpa pode desencadear uma série de problemas para a população consumidora, resultado da contaminação proveniente da falha do gerenciamento e manuseio do produto. A higienização é fundamental no processamento dos frutos do açaí, é o método mais importante no que se diz respeito à prevenção, sendo necessária a lavagem e a pasteurização (MIZOGUTI et al., 2018), etapas não observadas durante o processo de produção do vinho de açaí.

Nesse sentido, desde o início dos anos 2000, os Ministérios da Saúde, da Agricultura e do Abastecimento vem publicando leis e documentos que dispõe sobre o regulamento técnico para padronizar a qualidade da polpa do açaí, de modo que esta seja própria para o consumo. A Agência Nacional de Vigilância Sanitária (ANVISA), através da RDC no 218 de 29/07/2005, tem um regulamento técnico de procedimentos higiênico-sanitários para manipulação de alimentos e bebidas preparados com vegetais (BRASIL, 2005). E, a EMBRAPA, elaborou um procedimento para processamento de açaí, com etapas desde a colheita até congelamento e estoque visando tanto o processamento tradicional quanto o industrial (EMBRAPA, 2008).

\section{CONCLUSÃO}

Neste estudo de caso foi possível observar várias etapas incorretas no processo de preparo do vinho de açaí, desde o recebimento até o acondicionamento desse produto para comercialização, e sinaliza aos órgãos competentes de vigilância e fiscalização em saúde, a necessidade de constantes vistorias aos estabelecimentos de produção e vendas de açaí, para averiguar o cumprimento de regulamentos técnicos de boas práticas de fabricação desse alimento, visando a sua inocuidade como um fator protetivo contra a doença de Chagas. 


\section{REFERÊNCIAS}

BERNAUD, R. F. S.; FUNCHAL, C. D. S. Atividade antioxidante do açaí. Nutrição Brasil. 10 (5): 310-316. 2011.

BEZERRA, V. S. Açaí congelado / Valéria Saldanha Bezerra. - Brasília, DF: Embrapa Informação Tecnológica. 40. 2007.

COSTA, C. A.; OLIVEIRA, P. R.; BEM, G. F.; CAVALHO, L. C.; OGNIBENE, D. T.; SILVA, A. F.; VALENÇA, S. S.; PIRES, K. M.; SOUSA, P. J. C.; MOURA, R. S.; RESENDE, A. C. Euterpe oleracea Mart. derived polyphenols prevent endotelial dysfunction and vascular structural changes in renovascular hypertensive rats: role of oxidative stress. NaunynSchmiedeberg's Archives of Pharmacology. 385 (12): 1199-1209. 2012.

DARNET, S.; SERRA, J. L.; RODRIGUES, A. M. C.; SILVA, L. H. M. A high-performance liquid chromatography method to measure tocopherols in assai pulp (Euterpe oleracea). Food Research International. 44 (7): 2107-2111. 2011.

DIAS, J. C. P.; AMATO NETO, V. Prevenção referente às modalidades alternativas de transmissão do Trypanosoma cruzi no Brasil. Rev Soc Bras Med Trop. 44 supl 2:68-72. 2011.

HONZEL, D.; CARTER, S. G.; REDMAN, K. A.; SCHAUSS, A. G.; ENDRES, J. R.; JENSEN, G. S. Comparison of chemical and cell-based antioxidant methods for evaluation of foods and natural products: generating multifaceted data by parallel testing using erythrocytes and polymorphonuclear cells. Journal of Agricultural and Food Chemistry. 56 (18): 83198325. 2008.

[7] MIZOGUTI, I. E.; KOIAMA, J. R.; PASSOS, J. S. Boletim Informativo: Doença de Chagas: A culpa é do Açaí? Universidade de São Paulo. FBF0436 - Informação sobre o uso de medicamentos, uso racional e farmacovigilância. Junho. 1. 1. 2018.

JENSEN, G. S.; WU, X.; PATTERSON, K. M.; BARNES, J.; CARTER, S. G.; SCHERWITZ, L.; BEAMAN, R.; ENDRES, J. R.; SCHAUSS, A. G. In vitro and in vivo antioxidant and antiinflammatory capacities of an antioxidant-rich fruit and berry juice blend: results of a pilot and randomized, double-blinded, placebo-controlled, crossover study. Journal of Agricultural and Food Chemistry. 56 (18): 8326-8333. 2008.

MENEZES, E. M. S.; TORRES, A. T.; SRUR, A. U. S. Valor nutricional da polpa de açaí (Euterpe oleracea Mart) liofilizada. Acta Amazônica. 38 (2): 311-316. 2008.

OPAS. Organização Pan-americana da Saúde. Guia para vigilância, prevenção, controle e manejo clínico da doença de Chagas aguda transmitida por alimentos. Rio de Janeiro: Organização Pan-Americana da Saúde; 2009. (Série de Manuais Técnicos, 12).

PASSOS, L. A. C., et al. Sobrevivência e infectividade do Trypanosoma cruzi na polpa de açaí: estudo in vitro e in vivo. Epidemiol. Serv. Saúde, Brasília. 21(2):223-232. 2012.

ROCHA, A. P. M.; RESENDE, A. C.; SOUZA, M. A. V.; CARVALHO, L. C. R. M.; SOUSA, P. J. C.; TANO, T.; CRIDDLE, D. N.; PORTO, L. C.; VALENCA, S. S.; MOURA, R. S. Antihypertensive effects and antioxidant action of a hydro-alcoholic extract obtained from fruits of 
Euterpe oleracea Mart. (Açaí). Journal of Pharmacology and Toxicology. 3 (6): 435-448. 2008.

ROCHA, S. M. B. M.; OLIVEIRA, A. G.; COSTA, M. C. D. Benefícios funcionais do açaí na prevenção de doenças cardiovasculares. Journal of Amazon Health Science. 1 (1): 1-10. 2015.

ROGEZ, H. Açaí: preparo, composição e melhoramento da conservação. Belém: EDUFPA. 2000.

SHIKANAI-YASUDA, M. A.; CARVALHO N. B. Oral transmission of Chagas disease. Clin Infect Dis. 54(6): 845-52. 2012.

SOUSA, C. L.; MELO, G. M. C.; ALMEIDA, S. C. S. Avaliação da qualidade do açaí (Euterpe oleracea Mart.) comercializado na cidade de Macapá - AP. Boletim CEPPA, Curitiba.17 (2):127-136. 1999.

World Health Organization. Research priorities for Chagas disease, human African trypanosomiasis and leishmaniasis. WHO: technical report of the TDR Disease Reference Group on Chagas Disease, Human African Trypanosomiasis and Leishmaniasis. Geneva: World Health Organization. 2012.

World Health Organization. Sustaining the drive to overcome the global impact of neglected tropical diseases: second WHO report in neglected tropical diseases. Geneva: World Health Organization. 2013.

YAMAGUCHI, K. K. L.; PEREIRA, L. F.; LAMARÃO, C. V.; LIMA, E. S.; VEIGA-JUNIOR, V. F. Amazon acai: chemistry and biological activities: a review. Food Chemistry. 179: 137-151. 2015. 


\section{Capítulo 15}

Modelo estimativo da oferta de curto prazo de óleo comestível usado para produção de biodiesel

Ricardo Wilson Aguiar da Cruz.

Paula Figliuolo da Cruz Borges

Resumo: 0 óleo vegetal utilizado em frituras descartado de forma incorreta no meio ambiente torna-se um agente poluidor, pois tem a capacidade de alcançar toda a cadeia viva do entorno natural. Com o intuito de minimizar os efeitos danosos desse insumo secundário, este artigo apresenta uma estimativa do potencial do mercado de oferta de óleo comestível usado para a planta experimental de biodiesel da Escola Superior de Tecnologia (EST), da Universidade do Estado do Amazonas (UEA).

Palavras-chave: Descarte de óleo; Biodielização; Volume potencial de oferta. 


\section{INTRODUCĈ̃O}

A Escola Superior de Tecnologia (EST) da Universidade do Estado do Amazonas (UEA) construiu em suas dependências uma planta piloto de produção de biodiesel (óleo combustível compatível com gasóleo leve) a partir do reaproveitamento de óleo vegetal usado rejeitado de cozinhas domiciliares, no contexto de um projeto cujo objetivo é avaliar o uso desse combustível na geração de energia elétrica autônoma em pequena escala, compatível com o consumo de micro e pequenas indústrias e de conjuntos habitacionais. Nesse contexto, esse projeto opera conexo a um projeto de geração elétrica que conta com um grupo-gerador dieselétrico de $75 \mathrm{kVA}$. 0 projeto global visa dois cenários possíveis para o uso do biodiesel: puro e misturado em proporções variadas com o gasóleo.

A planta processadora de biodiesel é de origem coreana, tem capacidade instalada de 180 litro/batelada e foi doada à UEA pela Receita Federal do Brasil (obtida por apreensão alfandegária desse órgão). Como o objetivo da planta é a investigação acadêmica, sua produção projetada não tem relação com variáveis microeconômicas, senão com os subprojetos que serão concebidos no âmbito do objetivo principal. Não obstante, já na partida, um resultado esperado do projeto é pesquisar e mapear as maiores fontes de descarte de óleo de cozinha usado em Manaus, onde a coleta deve se concentrar vis-à-vis a capacidade instalada da planta de biodiesel. Como o consumo das famílias varia diretamente com a renda, o mercado de oferta de óleo vegetal usado é maior nas regiões onde se concentram as populações de maior poder aquisitivo, i.e. nas regiões de classe média da Cidade.

\section{MATERIAL E MÉTODOS}

\subsection{QUADRO ATUAL DO DESCARTE DE ÓLEO VEGETAL USADO}

As consequências do descarte no meio ambiente do óleo vegetal usado em frituras já são conhecidas. Várias referências globais (AMAZONAS ATUAL, 2018; DANTAS, 2012) e pontuais (A CRÍTICA, 2015; DANTAS, 2012) têm unânime opinião sobre os efeitos deletérios dessa agressão: do ponto de vista da sua difusão nos solos, cada 1 litro de óleo vegetal que acessa os recursos hídricos pode poluir entre 20 a 100 litros de água desse meio; enquanto Bezerra (2015) afirma que se descartado diretamente na rede de esgotos, o óleo vegetal usado pode contaminar até 1 milhão de litros d'água. Seja qual for a trajetória, esse agente poluidor alcança toda a cadeia viva do entorno natural.

Pesquisa feita pela Secretaria de Ciência e Tecnologia do Estado do Amazonas (SECT/AM), em parceria com a Universidade Federal do Amazonas (UFAM), como citado por dos Santos (2011), indicou que em 2009 cerca de 90\% do descarte de óleo vegetal usado em Manaus era feito nos esgotos e nas lixeiras, daí alcançando os cursos d'água que cortam a Cidade. Mais precisamente, esse trabalho apurou que a divisão se dá como indicado na Figura 1. Pode-se ver ali que a soma dos volumes dos dois únicos reusos existentes em Manaus, doação para alguma finalidade e reciclagem (não especificada), que juntas somam por volta de 7\%, é de longe inferior à soma dos demais, que são a expressão do que é lançado no meio ambiente. Pode-se inferir que essas figuras não mudaram desde 2009 até hoje, face ao desaquecimento da economia brasileira desde então, o que provavelmente tem refletido na receita tributária municipal, levando ao 
congelamento das iniciativas estratégicas da Prefeitura Municipal de Manaus (PMM) na área ambiental, elevando o descarte do óleo vegetal usado no meio ambiente.

0 problema do descarte na natureza não se restringe ao Amazonas. Segundo o pesquisador Santos (apud BEZERRA, 2015), da Faculdade de Tecnologia da Zona Leste de Manaus, esta catástrofe se estende a todo o território nacional, onde, estima Santos, se descartam anualmente 9 bilhões de litros de óleo vegetal usado, dos quais apenas $2,5 \%$ é reciclado.

Figura 1. Frações do descarte de óleo vegetal usado na Cidade de Manaus, AM.

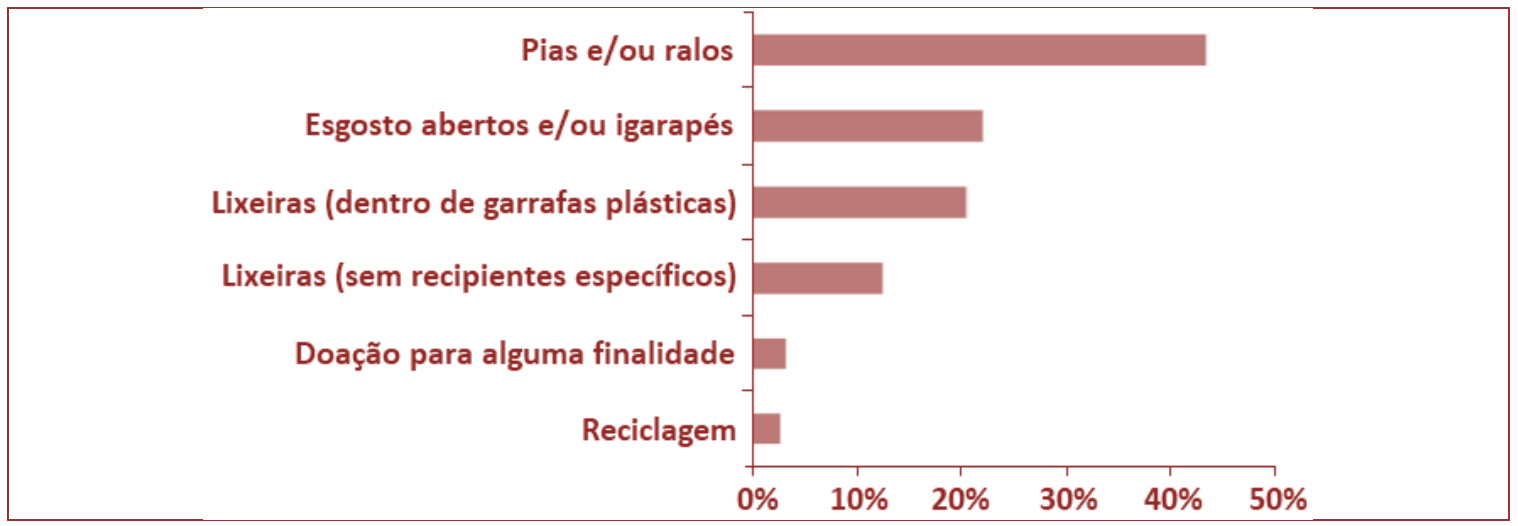

Fonte: dos Santos (2011).

É unânime a premência da reciclagem do óleo vegetal usado, enquanto um recurso renovável, visando afastá-lo do contato imediato com a natureza. 0 problema é que isso depende da vontade política dos gestores públicos e da conscientização da população, fatores que por si só são difíceis de alcançar. O que se deve fazer com esse produto é muito conhecido, com suas vantagens e desvantagens. É mister reconhecer que os poderes executivo e legislativo, numa tentativa de normatizar o setor, instituíram o Dec. $\mathrm{N}^{\circ}$ 0815/2011, regulamentado pela Lei $\mathrm{N}^{\circ} 1536 / 2010$. Mas poucos agentes têmno obedecido em Manaus, o que denota a consequência desses poderes não terem agido na direção do seu cumprimento. Assim, resulta que poucas cooperativas se cadastraram na Secretaria Municipal de Meio Ambiente e Sustentabilidade (SEMMAS), da PMM, para a coleta domiciliar. Uma parte muito pequena desse óleo tem sido encaminhado à produção de sabão artesanal por pequenos empreendedores. Destaque-se ainda que o volume coletado é muito pequeno. Em anos recentes, algumas empresas que atuam na coleta de resíduos industriais passaram a atuar nesse segmento, mas sem repercussão significativa no desperdício.

Neste trabalho, o destino objetivado é a produção de biodiesel (doravante referida como "biodielização"). A principal vantagem da biodielização do óleo vegetal usado é a sua destinação à geração energética em vários setores (transporte, eletricidade, calor, etc.). A grande desvantagem da biodielização é a geração de muita glicerina, um problema hoje de escala nacional. 


\section{MATERIAL E MÉTODOS}

\subsection{CARACTERIZAÇÃO DO PROBLEMA}

No estado da arte, a geração de glicerina nesse processo, no Brasil, está por volta de $10 \%$ do volume de biodiesel produzido, o que, segundo estimativas de 2010 da Revista Biodieselbr (A CRÍTICA, 2015), representou a geração de algo como 230 milhões de litros naquele ano, num mercado de oferta onde a capacidade instalada da indústria petroquímica para produção desse produto foi de 41,5 milhões de litros, frente a um consumo da ordem de 30 milhões de litros. Afora a estocagem dessa imensa quantidade de glicerina residual, para a qual o setor produtivo do biodiesel não vislumbra a absorção no curto prazo, eis que as propostas tecnológicas ainda se restringem a pesquisas acadêmicas, tem havido iniciativas de exportação para um mercado global extremamente competitivo e dependente da qualidade, restrição que obriga o produtor de biodiesel a ir na direção de investimentos adicionais para atendê-la.

Provavelmente, uma alternativa para absorver grande parte dessa glicerina residual será seu processamento químico a permitir queimá-la em fornos e geradores de vapor industriais. Ou seja, esse subproduto se tornaria um coproduto com valor agregado. Nesse caso, porém, sua queima pode liberar na atmosfera a substância cancerígena acroleína, se processada a baixas temperaturas de combustão $\left(<300^{\circ} \mathrm{C}\right)(\mathrm{A}$ CRÍTICA, 2015). Há que se reconhecer que isso, mais a queima do biodiesel em si, consiste na transferência de carbono para a atmosfera que, de outro modo, na escala própria, seria transferido pelo óleo vegetal usado à litosfera e à hidrosfera do Planeta. Novamente, isso arremeteria as cadeias produtiva e consumidora na direção da necessidade de grandes investimentos.

0 concorrente da biodielização na Cidade de Manaus, ainda que em pequena escala, é a produção de sabão artesanal. Em termos volumétricos, a escala de uso do rejeito nessa atividade é muito menor do que a produção de biodiesel pode propiciar à reciclagem. Porém, a produção de sabão caseiro tem a vantagem de ser uma fonte de renda com alcance social inegavelmente maior que a industrialização, que é notória concentradora de riqueza. Sendo assim, a produção de sabão artesanal tem como grande vantagem o cunho social. Como desvantagem, há que se mencionar que o sabão, fruto de várias fontes, às quais a produção artesanal certamente se agrega, é um dos vilões da poluição dos cursos d'água urbanos, onde produz espumas densas estáveis que criam o mesmo efeito bloqueador que teria o óleo usado se descartado nesse meio (talvez não em magnitude), qual seja, a troca de gases, assim eliminando a absorção de oxigênio, ou, dito de outro modo, elevando a demanda bioquímica de oxigênio (DBO) dos cursos d'água na natureza.

\subsection{ESTRATÉGIA DE ESTIMAÇÃO DA OFERTA DE ÓLEO VEGETAL USADO EM MANAUS}

0 potencial de oferta de óleos vegetais usados na Cidade de Manaus tem relação com o consumo de óleo novo, a renda, a população, o descarte na natureza e as aplicações sucedâneas do óleo usado (e.g. a fabricação de sabões caseiros). Algumas dessas variáveis são linearmente dependentes entre si, o que dificulta suas parametrizações. Um modelo econométrico completo, ideal do ponto de vista acadêmico, é trabalhoso de ser obtido, posto que exige a coleta de dados históricos dessas variáveis, um esforço que no contexto do presente estudo é julgado desnecessário, face ao propósito primário de 
delimitar um mercado com potencial de oferta de óleo vegetal usado suficiente para a pequena escala de reaproveitamento experimental da planta piloto da EST-UEA. Uma característica esperada desse modelo é que possa, inclusive, ser aplicado em pequenas áreas urbanas e, assim, fornecer valores de condições iniciais e de contorno para um possível modelo analiticamente mais complexo (econométrico).

0 presente estudo estima o volume potencial de oferta de óleo vegetal usado para biodielização por um modelo simples que seleciona entre suas variáveis explicativas as mais significativas e suficientes para tanto. A estratégia assumida é a caracterização da natureza dessas variáveis nas próximas subseções.

\section{RESULTADOS E DISCUSSÃO}

\subsection{CONSUMO DE ÓLEO NOVO}

Considerando toda a Cidade de Manaus, é de esperar que o volume de óleo novo consumido e, portanto, a oferta de óleo usado seja grande. Porém, como a planta de biodiesel da EST-UEA tem pequena escala de produção, o mais sensato é estabelecer uma estratégia de coleta nas zonas administrativas da cidade que tenham, ao mesmo tempo, maior proximidade à localização da planta e maior renda econômica (poder de compra), o que implica maior consumo de óleo vegetal. Numa primeira abordagem, considera-se apenas o consumo familiar e despreza-se o consumo das indústrias, dos bares e dos restaurantes. Esse panorama foca as zonas administrativas oficiais da Prefeitura Municipal de Manaus (PMM).

Para fins estimativos, assume-se o consumo específico mensal familiar de óleo novo (c) apurado na pesquisa conjunta SECT/ UFAM (DOS SANTOS, 2011), para Manaus, no ano de 2009, de 2,82 litro/família.mês. Importa observar que este valor é conservador e bem inferior ao valor nacional estimado pela Associação Brasileira das Indústrias de Óleo (ABIOVE), de 4 litro/família.mês. Nesse sentido, aqui se considera que cada família manauara se compõe, em média, de 5 indivíduos. Portanto, o consumo anual de óleo novo, ou demanda ( $D$ [litro/ano]), cujo número de famílias é $F$ [unid.] e a população é $P$ [hab.], é dado como:

$$
D=c F=2,82\left(\frac{P}{5}\right) \cdot 12=6,768 P
$$

\subsection{RENDA E POPULAÇÃO}

O papel da variável renda no modelo simples deste trabalho não é quantitativo, mas o de servir como indicativo de decisão da área de coleta da planta da EST-UEA. Num modelo econométrico completo, a renda da população, que em Manaus é estratificada social e geograficamente (o que é inerente aos levantamentos do IBGE), teria que ser levantada no tempo e no espaço, segundo os grupos de estratificação social do IBGE, o que, como já discutido, transcenderia em muito o objetivo primário deste trabalho.

Segundo dados do PNUD Brasil do ano 2000, da ONU, elaborado a partir de dados compilados do IBGE, as classes de maiores rendas de Manaus estão nos bairros de Adrianópolis e Nossa Senhora das Graças, ambos da Zona Centro-Sul (Figura 2), que têm índice de qualidade de vida (IDH) de 0,943, semelhante ao da Noruega (Wikipédia, 2020). 
Ainda desse estudo, as zonas administrativas de Manaus com melhor qualidade de vida são a Centro-Sul, a Oeste e o bairro Cidade Nova (parte da Zona Norte - Figura 2). Já as menores rendas se localizam no Bairro São José Operário (Zona Leste - Figura 2) e na Comunidade Grande Vitória (Zona Leste - Figura 2), pertencente ao Bairro Gilberto Mestrinho, com IDH de 0,658, equiparável ao da Bolívia (Wikipédia, 2020). Isso sugere que a locação dos postos de coleta, que darão partida ao projeto da planta da EST-UEA, deve se dar nas zonas Centro-Sul e Oeste, devido à proximidade entre essas zonas e a planta. Colabora também o fato dessas zonas possuírem maior renda e, provavelmente, bom nível educacional, o que favorece o apelo ambiental que a planta de biodiesel possui e deve ser explorado pelas campanhas motivacionais necessárias junto à população.

Os bairros das zonas administrativas onde se desenvolverão as estratégias de coleta da planta da EST-UEA são dados na Tabela 1. Ali se tem a população estimada de 2017 desses bairros nas respectivas zonas administrativas da PMM, segundo a SEDECTI (2017).

Figura 2. Zonas administrativas da Cidade de Manaus, Amazonas.

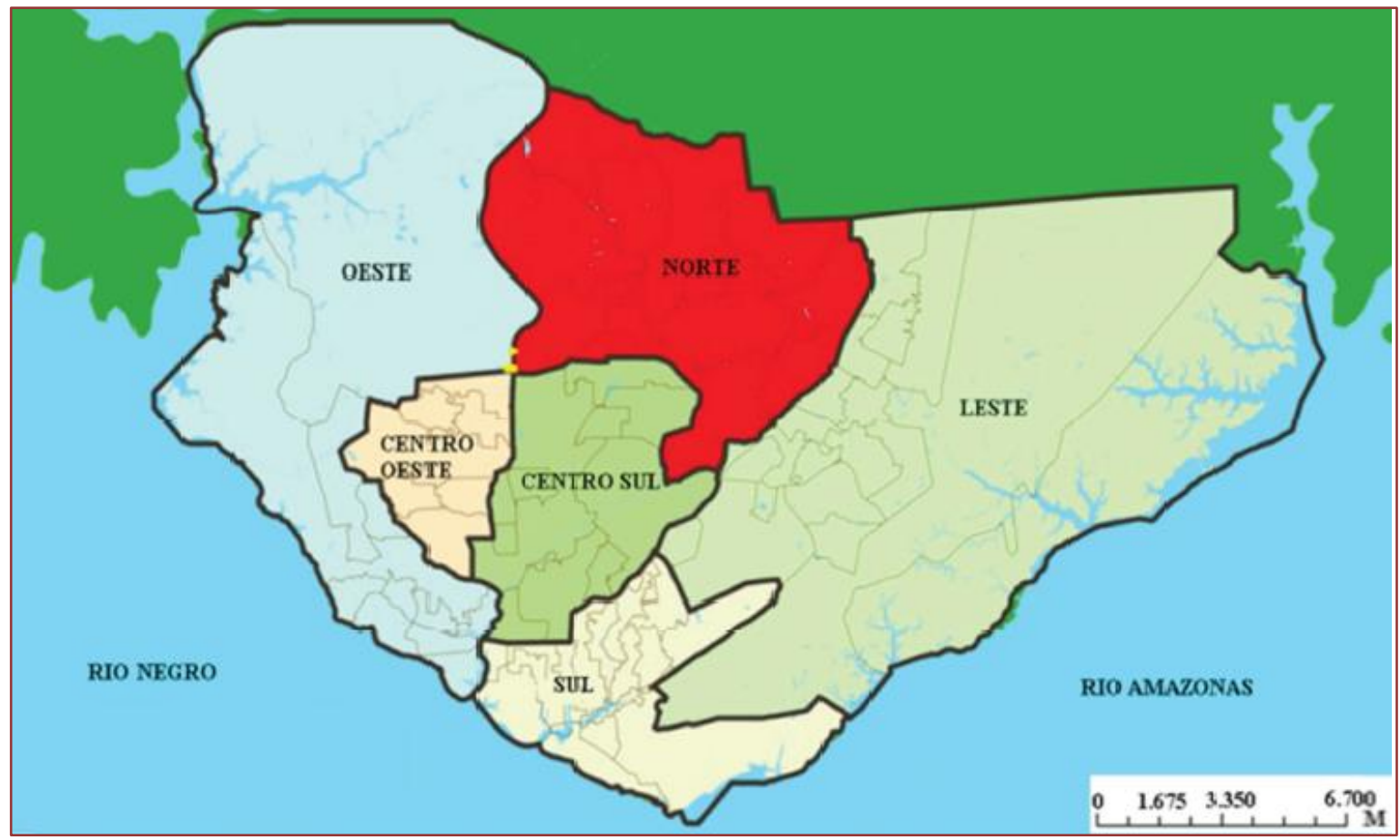

Fonte: dos Santos (2011).

Segundo as estimativas do IBGE (2010), a população de Manaus variou de 2011 a 2020 como o mostra o gráfico da Figura 3. O IBGE não disponibiliza estimativas de variação da população dos bairros/zonas administrativas da Cidade.

Então, aqui se consideram as variações populacionais da Cidade como um todo como aproximações para essas zonas (que são obviamente subestimadoras, porque não relevam a renda locacional). No caso, tomam-se apenas os valores dos anos 2018, $2019 \mathrm{e}$ 2020 , relativamente aos seus respectivos anos precedentes. 
Tabela 1. Distribuição Populacional da Cidade de Manaus por Bairro e Zona - 2017.

\begin{tabular}{|c|c|c|}
\hline Bairro & $\begin{array}{c}\text { Zona } \\
\text { Administrativa }\end{array}$ & $\begin{array}{r}\text { População } \\
\text { Estimada }\end{array}$ \\
\hline Adrianópolis & Centro-Sul & 10.459 \\
\hline Aleixo & Centro-Sul & 24.417 \\
\hline Chapada & Centro-Sul & 13.219 \\
\hline Compensa & Oeste & 89.645 \\
\hline Flores & Centro-Sul & 56.859 \\
\hline Glória & Oeste & 10.617 \\
\hline Lírio do Vale & Oeste & 25.457 \\
\hline Nossa Senhora das Graças & Centro-Sul & 17.869 \\
\hline Nova Esperança & Oeste & 20.919 \\
\hline Parque 10 de Novembro & Centro-Sul & 48.771 \\
\hline Ponta Negra & Oeste & 5.919 \\
\hline Santo Agostinho & Oeste & 19.616 \\
\hline Santo Antônio & Oeste & 23.356 \\
\hline São Francisco & Centro-Sul & 19.889 \\
\hline São Geraldo & Centro-Sul & 8.983 \\
\hline São Jorge & Oeste & 25.585 \\
\hline São Raimundo & Oeste & 18.199 \\
\hline Tarumã & Oeste & 33.168 \\
\hline Tarumã-Açu & Oeste & 14.249 \\
\hline \multicolumn{2}{|c|}{ TOTAL } & 487.196 \\
\hline
\end{tabular}

A Figura 3 permite construir um modelo polinomial ajustado àqueles valores, que retorne o valor do índice de variação populacional $(V)$ de cada um dos três anos considerados $(A)$, como sendo:

$$
V=-20.390,883+20,195 A-0,005 A^{2}
$$

Este modelo é usado para estimar a população dos bairros/zonas administrativas da Tabela 1, nos três anos analisados (2018, 2019 e 2020), extrapolados do valor da população do ano de 2017, os quais se espera que mantenham a mesma tendência polinomial dos índices da Figura 3. Obviamente, o modelo não captura os porquês socioeconômicos das variações naquela figura.

\subsection{DESCARTE DE ÓLEO USADO NO MEIO AMBIENTE NATURAL}

Dados da Associação Brasileira das Indústrias de Óleo (ABIOVE) apontam que, do consumo mensal de cada família brasileira, somente $10 \%$ são de alguma forma reciclados DANTAS (2012). Os 90\% restantes são jogados na natureza. Este valor da reciclagem é usado no modelo simples deste trabalho.

No Amazonas, em particular, grande parte do óleo novo consumido pelas famílias é usado na fritura de pescado, que é um componente forte da culinária regional, onde alcança um consumo específico da ordem de $50 \mathrm{~kg} / \mathrm{hab}$. ano. Este índice é muito superior à média nacional, por volta de 9,5 kg/hab.ano, segundo o Relatório Psicultura da Secretaria de Estado da Agricultura e do Abastecimento do Paraná (SEAB) (PSICULTURA, 2019). Mencione-se que a Organização das Nações Unidas para Alimentação e Agricultura (FAO) recomenda um mínimo de 12 kg/hab.ano. 
Figura 3. Índices de variação populacional da Cidade de Manaus.

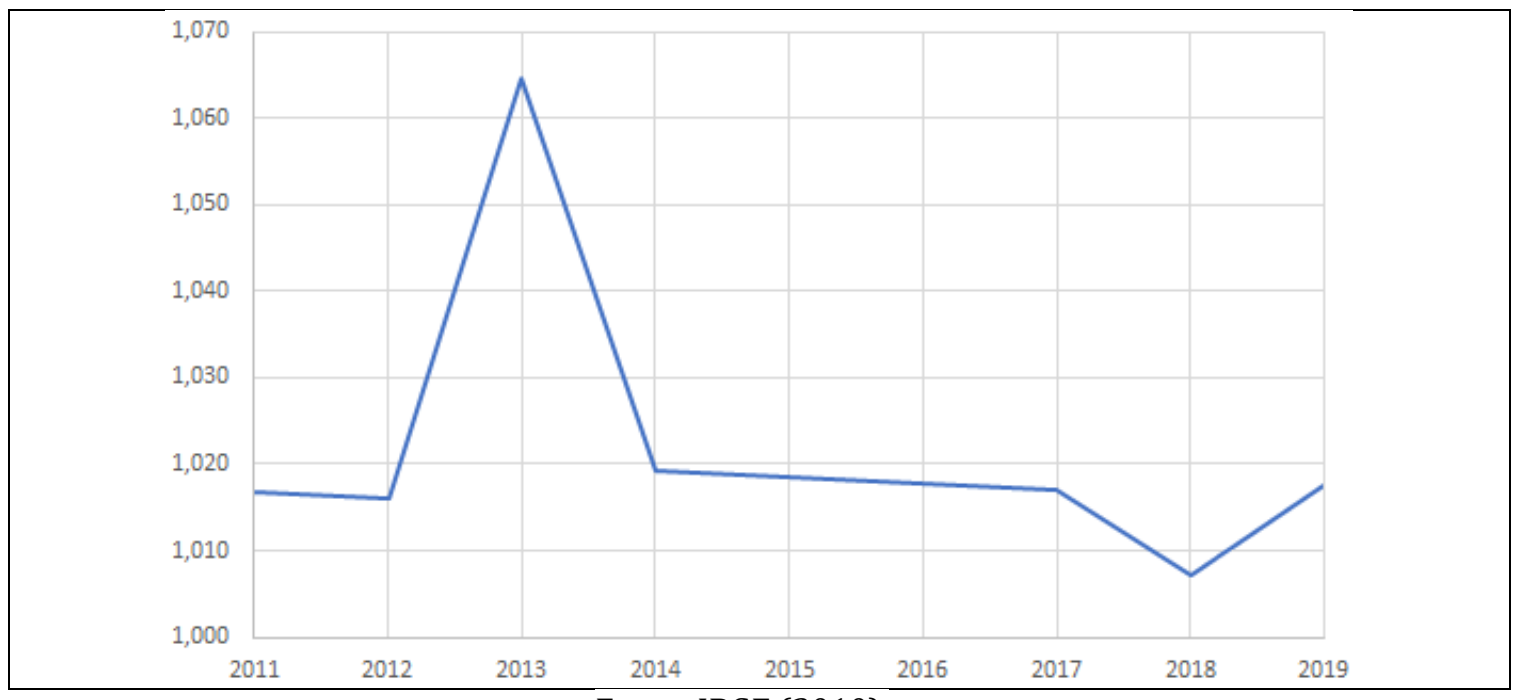

Fonte: IBGE (2010).

\section{4. ÓLEO USADO NA PRODUÇÃO DE SABÃO ARTESANAL}

Em Manaus, a produção de sabão artesanal responde pelo único aproveitamento sucedâneo do óleo vegetal usado, no que pese isso representar um volume ínfimo do total consumido de óleo novo. Na região Sudeste, óleo novo tem sido usado como componente de lubrificantes especiais e como insumo de produção de tintas, o que também poderia ser feito com óleo usado se limpo de contaminantes oriundos de fritura. Não obstante, não há registros dessa destinação no País.

As menções ao reaproveitamento de óleo vegetal usado na confecção de sabão artesanal em Manaus não especificam volumes (A CRÍTICA, 2015), e provêm da coleta dos doze pontos de entrega voluntária (PEV) montados pela Secretaria Municipal de Limpeza Pública (SEMULP) da PMM, geridos pelas associações de catadores de resíduos (A CRÍTICA, 2015). Quando instalados, em 2012, a SEMULP realizou alguma campanha de divulgação dos PEV entre a população. Tais pontos têm as seguintes localizações:

- Distrito de Obras da Cidade Nova, situado na Avenida Noel Nutels (Zona Norte);

- Parque do Mindu, localizado no bairro Parque 10 (Zona Centro-Sul);

- Fórum Henoch Reis, situado na Avenida André Araújo, Aleixo (Zona CentroSul);

- Parque Lagoa do Japiim, situado na Avenida Rodrigo Otávio (Zona Sul);

- Praça do Dom Pedro, situada na Avenida Pedro Teixeira (Zona Centro-Oeste);

- Supermercado Makro, localizado na Manaus Moderna (Zona Centro-Oeste); e

- Parque dos Bilhares, localizado na Avenida Constantino Nery (Zona Sul).

Notícia da Revista Biodieselbr (A CRÍTICA, 2015) informa que em 2015 apenas dois destes PEV tiveram maiores entregas de óleo usado, reservadas pela população em 
garrafas PET. Os motivos alegados pelos demais pontos para suas baixas produtividades são todos associados à desinformação, nos quais a PMM tem parte da culpa. Um desses pontos é o da Associação de Reciclagem e Preservação Ambiental (ARPA), da Praça do Dom Pedro, que contabiliza algo como 12.000 litro/mês de óleo vegetal usado (A CRÍTICA, 2015).

Não há ainda algum estudo confiável que tenha contabilizado o volume de óleo vegetal usado na produção de sabão artesanal em Manaus. Por esta razão, a planta da EST-UEA planeja contar com o apoio dos pontos de coleta da PMM em regime de parceria, porém secundariamente, face aos pontos de coleta próprios que planeja instalar nas zonas administrativas listadas na subseção 2 deste trabalho.

O ponto em que todas as referências são unânimes é na afirmação de que, de todo o óleo vegetal novo consumido em Manaus, apenas uns $10 \%$ são reciclados. Seguramente, desses $10 \%$, uma parcela muito pequena se transforma em sabão artesanal. Corrobora esta conclusão o fato de que, por informação pessoal, a empresa Masseg Serviços (A CRÍTICA, 2015), recolhe em média 90 t/mês (aproximadamente 13.000 litro/mês) de óleo vegetal usado em Manaus, junto a restaurantes e associações, que usa na produção de biodiesel, sem mencionar se o faz no Amazonas, pois, já que há exportação de óleo lubrificante automotivo (óleo de natureza mineral) de Manaus para outras regiões do País, pode também haver de óleo vegetal usado.

Dessa forma, esta parcela sucedânea da biodielização na reciclagem de óleo vegetal usado é considerada desprezível no presente estudo.

\subsection{MODELO DE ESTIMAÇÃO DA OFERTA DE ÓLEO VEGETAL USADO}

Um modelo simples é obtido reunindo o resultado (1), do volume anual de óleo novo, e o índice de reaproveitamento médio do óleo rejeitado $r=0,1$ (10\%), da subseção 3 , do que se obtém o volume de óleo usado disponível em cada ano $i$, dado como $r \cdot 6,768 P_{i}$. A população anual neste resultado, dos bairros/zonas administrativas de Manaus, é estimada nos anos $i$ pelo resultado (2), usando o valor populacional do ano de referência (2017) de cada bairro/zona administrativa, $P_{\text {ref }}$.

Então, como resultado, tem-se que o volume de oferta anual de óleo usado disponível $\left(O_{i}\right.$ [litro/ano]) de cada bairro/zona administrativa de Manaus, em cada ano $i$, $A_{i}(2018,2019$ e 2020), pode ser estimado por:

$$
O_{i}=6,768 r P_{\text {ref. }} \prod_{i=2018}^{2020}\left(-20.390,883+20,195 A_{i}-0,005 A_{i}^{2}\right)
$$

A Tabela 2 expõem valores de $O_{i}$ nos bairros e zonas administrativas da Tabela 1. 
Tabela 2 - Oferta Anual de Óleo Vegetal Usado disponível por Bairro e Zona Administrativa na Região Visada pela Planta de Biodiesel da EST/UEA.

\begin{tabular}{|l|c|c|c|c|}
\multicolumn{2}{r}{} & \multicolumn{2}{c}{ Zona } & \multicolumn{2}{c}{ Oferta de óleo usado disponível } \\
\cline { 2 - 4 } & Administrativa & 2018 & 2019 & 2020 \\
\hline Adrianópolis & Centro-Sul & 7.128 & 7.249 & 7.373 \\
\hline Aleixo & Centro-Sul & 16.641 & 16.924 & 17.212 \\
\hline Chapada & Centro-Sul & 9.009 & 9.162 & 9.318 \\
\hline Compensa & Oeste & 61.096 & 62.135 & 63.191 \\
\hline Flores & Centro-Sul & 38.752 & 39.410 & 40.080 \\
\hline Glória & Oeste & 7.236 & 7.359 & 7.484 \\
\hline Lírio do Vale & Oeste & 17.350 & 17.645 & 17.945 \\
\hline Nossa Senhora das Graças & Centro-Sul & 12.178 & 12.385 & 12.596 \\
\hline Nova Esperança & Oeste & 14.257 & 14.499 & 14.746 \\
\hline Parque 10 de Novembro & Centro-Sul & 33.239 & 33.804 & 34.379 \\
\hline Ponta Negra & Oeste & 4.034 & 4.103 & 4.172 \\
\hline Santo Agostinho & Oeste & 13.369 & 13.596 & 13.827 \\
\hline Santo Antônio & Oeste & 15.918 & 16.189 & 16.464 \\
\hline São Francisco & Centro-Sul & 13.555 & 13.786 & 14.020 \\
\hline São Geraldo & Centro-Sul & 6.122 & 6.226 & 6.332 \\
\hline São Jorge & Oeste & 17.437 & 17.734 & 18.035 \\
\hline São Raimundo & Oeste & 12.403 & 12.614 & 12.829 \\
\hline Tarumã & Oeste & 22.605 & 22.990 & 23.380 \\
\hline Tarumã-Açu & Oeste & 9.711 & 9.876 & 10.044 \\
\hline \multicolumn{2}{|c|}{} & $\mathbf{3 3 2 . 0 4 2}$ & $\mathbf{3 3 7 . 6 8 7}$ & $\mathbf{3 4 3 . 4 2 8}$ \\
\hline
\end{tabular}

A capacidade instalada da planta de biodiesel da EST/UEA, de 180 litro/batelada, poderá ser manuseada de modo a alcançar vários níveis de produção anual. Numa primeira aproximação, idealiza-se o seguinte cenário:

- Consumo específico de combustível do grupo-gerador dieselétrico (GGD) de 75 kVA: 0,3 litro/kWh;

- Geração elétrica média do GGD operando no regime 3 h/dia: 46.440 $\mathrm{kWh} / \mathrm{ano}$;

- Consumo de combustível do GGD sob o regime 3 h/dia: 14.000 litro/ano;

- Rendimento médio de conversão do óleo usado em biodiesel esperado da planta de biodiesel: $85 \%$.

Desse modo, pode-se estimar que a demanda de óleo vegetal usado da planta da EST/UEA é da ordem de 16.471 litro/ano $\approx 16.500$ litro/ano.

O cotejamento dessa estimativa de demanda da planta com os valores da Tabela 2 permite ver que bastam as ofertas potenciais de dois bairros da região de coleta, quando não apenas de um, para que o cenário acima se satisfaça. Obviamente, isso exigirá que a estratégia de coleta contemple ações midiáticas motivacionais, sem o que não haverá participação da população. Para tanto, o projeto deverá explorar o provável bom nível educacional da região definida neste estudo. 


\section{CONCLUSÃO}

A correlação adotada neste estudo, do consumo de óleo vegetal e a população, é suficiente para uma avaliação inicial do volume de oferta desse insumo secundário, contemplando a área geográfica selecionada, que é bastante maior que a capacidade de produção de biodiesel da planta-modelo. Isso permite inferir que o descarte desse óleo está criando impactos poderosos, mas pouco visíveis, no meio ambiente natural.

\section{AGRADECIMENTOS}

Os autores agradecem o apoio financeiro da Fundação de Apoio Institucional do Estado do Amazonas (FAPEAM), sem o que a montagem da planta de biodiesel da ESTUEA não teria se viabilizado.

\section{REFERÊNCIAS}

AMAZONAS ATUAL, 2018. Campanha em Manaus coleta óleo de cozinha usado para produzir sabão. Disponível em: http://amazonasatual.com.br/campanha-em-manauscoleta-oleo-de-cozinha-usado-para-produzir-sabao/. Acesso em: 20/10/2020.

BEZERRA, J.A.C. A Utilização do Óleo Comestível Pós-Consumo em Manaus (AM): Alternativa para a Produção de Biodiesel e Redução de Impactos Ambientais. Dissertação de Mestrado Profissional. Universidade Federal do Pará. Belém, 2015.

A CRÍTICA. 2015. Apenas $10 \%$ do óleo de cozinha descartado é reciclado em Manaus., 2015. Disponível em: <https://www.biodieselbr.com/noticias/materiaprima/ogr/apenas-10-oleo-cozinha-descartado-reciclado-manaus-050615> Acesso em: $23 / 10 / 2020$.

DOS SANTOS, V.O. Aproveitamento do Óleo de Fritura Residual para Produção de Biodiesel em Manaus. Dissertação de Mestrado. Universidade Federal do Amazonas. Manaus, 2011.

DANTAS, M. Sabão feito de óleo de cozinha gera renda para comunidade, em Manaus. G1 Amazonas, $2012 . \quad$ Disponível em: <http://g1.globo.com/am/amazonas/noticia/2012/06/sabao-feito-de-oleo-de-cozinhagera-renda-para-comunidade-em-manaus.html>. Acesso em: 23/10/2020.

SEDECTI - Secretaria de Estado de Desenvolvimento Econômico, Ciência, Tecnologia e Inovação. Mapa da área urbana da cidade de Manaus, 2017.

Lista de Bairros da Cidade de Manaus. Wikipédia, 2020. Disponível em: <https://pt.wikipedia.org/wiki/Lista_de_bairros_de_Manaus>. Acesso em: 22/10/2020.

PSICULTURA. 2019. Análise da Conjuntura. Disponível em: <http://www.agricultura.pr.gov.br/sites/default/arquivos_restritos/files/documento/2 019-11/aquicultura2019v1.pdf>. Acesso em: 22/10/2020.

IBGE - Instituto Brasileiro de Geografia e Estatística. Censo Demográfico de 2010. Brasília, 2010. 


\section{Capítulo 16}

Perfil microbiológico de placas de manipulação de alimentos, oriundas de uma Instituição de Ensino Superior de Manaus, Amazonas

Gabay Manuel Marques Reis Silva

Sabrina da Fonseca Meireles

Francimeire Gomes Pinheiro

Resumo: Doenças gastrointestinais associadas a microrganismos ainda têm causado preocupação na humanidade. Considerando as superfícies de manipulação (placas de corte), um dos principais meios de contaminação durante o preparo dos alimentos, foi proposto a realização deste estudo, com o objetivo de analisar as superfícies das tábuas de cortes utilizadas no preparo de alimentos nos laboratórios-cozinha de uma instituição de ensino superior da cidade de Manaus, Amazonas, por meio de métodos microbiológicos. Para isso, coletas foram realizadas nas tábuas com auxílio de swab, as quais foram submetidas aos meios de cultivos clássicos, para bactérias e fungos, como: Ágar Saboraund, Plate-Count Ágar e Ágar Eosina Azul de Metileno. Cerca de 90\% das superfícies analisadas apresentaram crescimento microbiano acima dos valores permitidos para utensílios utilizados no preparo de alimentos. Foram observados o crescimento de bactérias como enterobactérias e fungos (bolores e leveduras). Estes resultados são importantes, pois sinalizam a necessidade da realização de higienização correta dessas superfícies, para uso no processo de fabricação de alimentos. Uma alternativa para esse problema, seria a implantação de manuais de boas práticas de higienização e armazenamento dos utensílios, a fim de se obter condições higiênicosanitárias mais satisfatória.

Palavras-chave: Doenças gastrointestinais, Análises Microbiológicas, Superfície de Manipulação, Bactérias, Fungos. 


\section{INTRODUÇÃO}

A alimentação e a nutrição são requisitos básicos para saúde e permitem uma boa qualidade de vida. Aliado a qualidade dos alimentos, a segurança alimentar é de suma importância para a manutenção da saúde pública, pois os alimentos podem sofrer contaminações ao longo das etapas de elaboração, possibilitando o desenvolvimento de doenças de origem alimentar (PINHEIRO et al., 2010; MARCHI et al., 2011; FLORES e MELO, 2015).

A segurança alimentar tem por objetivo, limitar a concentração de agentes patogênicos nos alimentos (SCHOTHORST, 1998). Nesse intuito, diversas metodologias e ferramentas estão sendo desenvolvidas para auxiliar a identificação e quantificação de nocividade dos microrganismos patogênicos nos alimentos, entre elas, destaca-se a avaliação de riscos - estimativa da probabilidade da ocorrência de um efeito adverso ao consumidor, causando danos à sua saúde (NOTERMANS et al.,1998; ROQUE-SPECHT et al., 2007).

Existem várias doenças associadas a patógenos, as do trato gastrointestinal por exemplo, na maioria dos casos são Doenças Transmitidas por Alimentos (DTA). Existem cerca de 250 tipos de doenças alimentares, responsáveis por sérios problemas de saúde pública e expressivas perdas econômicas (OLIVEIRA et al., 2010). Os microrganismos causadores de DTA podem ser transmitidos através de manipuladores cuja mãos estejam contaminadas por resquícios fecais; pela água utilizada no preparo dos alimentos e por insetos voadores ou rasteiros (JAY, 2005; SOARES et al., 2006; MURRAY et al., 2009).

Estudos conduzidos por Chouman et al. (2010) em restaurantes, mostrou a presença de bactérias do grupo coliformes a $35^{\circ} \mathrm{C}$ e $45^{\circ} \mathrm{C}$, acima dos padrões permitidos. Esses microrganismos são indicadores de contaminação fecal, o que apontam uma higiene insuficiente no preparo de alimentos para o consumo humano nesses locais de venda. No Brasil, dados epidemiológicos a DTA's ainda são escassos, sendo essa doença negligenciada pelos órgãos de saúde, porém, devido as condições de saneamento básico precários, fortes indícios apontam uma elevada ocorrência de doenças desse tipo no Brasil (FRANCO e LANDGRAF, 2008).

Grande parte dos casos de DTA são decorrentes da manipulação inadequada de alimentos rotineiramente consumidos. Dentre as inadequações, destaca-se a falta de assepsia e conservação do utensílio utilizado como superfície em restaurantes e demais estabelecimentos de consumo. As variedades de materiais usados como superfície possibilitam a adesão e crescimento microbiano, levando a propagação de microrganismos contaminantes (ROSSI, 2006; ANDRADE, 2008; VERBENO et al., 2012).

As superfícies das placas usadas no preparo dos alimentos devem obedecer aos seguintes requisitos: ser livres de rugosidades ou outros tipos de elevações que possam ser limitadores da sua higienização e; apresentar aspecto liso e impermeável, características que facilitam a lavagem correta desses materiais. As placas de madeira não apresentam quaisquer requisitos apresentados anteriormente, o que as tornam impróprias para uso nos processos de manipulação de alimentos (BRASIL, 2004).

A procura pelos cursos na área de alimentação cresceu consideravelmente nas instituições de ensino superior, logo fez-se necessário a implantação de boas práticas que visam a segurança alimentar nas cozinhas experimentais (acadêmicas). Um dos equipamentos mais utilizados em cozinhas são as superfícies de corte, que podem ser de 
plásticos, pedra e vidro. Além de essenciais nas cozinhas, esses equipamentos são veículos de propagação de microrganismos e consequentemente ocasionam contaminação dos alimentos devido a higiene insatisfatória desses materiais (WILLIAMS, 2011).

Nesse contexto, foi proposto a realização desta pesquisa com o objetivo de realizar uma análise microbiológica das superfícies das placas de corte, utilizadas no preparo de alimentos nos laboratórios-cozinha de uma instituição de ensino superior em Manaus, Amazonas, a fim de reiterar a necessidade do rigor no processo de higienização dessas estruturas, importantes no processo de produção de alimentos.

\section{REFERENCIAL TEÓRICO}

\subsection{PRINCIPAIS ANÁLISES MICROBIOLÓGICAS DE ALIMENTOS}

De acordo com a Organização Mundial da Saúde (OMS) as doenças transmitidas por alimentos são aquelas de natureza infecciosa ou tóxica causadas pela ingestão de alimentos ou água contaminados por agentes biológicos, químicos e físicos, representando um sério risco à saúde (BRASIL, 2010).

Estima-se que mundialmente, 48 milhões de pessoas ficam doentes devido a alimentos contaminados por ano, são doenças transmitidas por alimentos, a maioria causada por microrganismos como vírus, bactérias e parasitos (CDC, 2018).

De acordo com a ANVISA (Agência Nacional de Vigilância Sanitária), os parâmetros microbiológicos de alimentos para o consumo humano, são baseados pela RDC 12 de 2001, que determina os seguintes critérios para análise: os microrganismos de interesse sanitário, a classificação dos alimentos segundo risco epidemiológico, métodos de detecção de microrganismos e planos de amostragem (BRASIL, 2001).

No Brasil o controle de segurança alimentar é regido pelo Ministério da Saúde, mais precisamente pela ANVISA e pelo MAPA (Ministério da Agricultura, Pecuária e Abastecimento), de acordo com o decreto lei número 986, de 21 de outubro de 1969, no 6437, de 20 de agosto de 1977, a lei 7889, de 23 de novembro de 1989. A competência destes órgãos é prevenir e controlar as doenças transmitidas por alimentos, que podem ser causadas por contaminantes químicos, biológicos e físicos (AFONSO, 2006; FORSYTHE, 2013).

\subsection{MICRO-ORGANISMOS DE IMPORTÂNCIA SANITÁRIA}

As bactérias são microrganismos ubíquas de alta incidência, diversidade e virulência, o que lhes confere grande importância frente à sua capacidade de provocar doenças (SILVA et al., 2017). No Brasil, os principais agentes etiológicos em surtos alimentares ocorridos entre 2007 e 2017 foram: Bacillus cereus, Clostridium sulfitos redutores, coliformes termotolerantes, Listeria monocytogenes, mesófilos, Staphylococcus termotolerantes e Salmonella spp., sendo essas bactérias, as reponsáveis por 95, 9\% das infecções, segundo o Ministério da Saúde (MS, 2017).

As manifestações clínicas das bactérias causadoras doenças transmitidas por alimentos podem ser divididas em grupos, a saber: (1) as infecciosas de maior importância, que são Salmonella, Campylobacter e E. coli; (2) as principais intoxicantes Bacillus cereus, Staphylococcus aureus e Clostridium botulinum; (3) as toxigênicas - E. coli 
e; (4) as enterotoxigênicas - Vibrio cholerae, Vibrio parahaemolyticus, Clostridium perfringens e Bacillus cerus (BRASIL, 2010).

Os fungos também são encontrados em praticamente todos os ambientes, e são economicamente importantes na medicina, na fitopatologia e na indústria, além de serem ecologicamente importantes como decompositores. Os fungos filamentosos, também conhecidos como bolores ou mofos em alimentos, podem contaminá-los, causando sua deterioração, reduzindo seu valor nutricional, alterando suas qualidades organolípticas e tornando-se, em alguns casos, problema de saúde pública (RAVEN et al., 2001).

Os fungos como Aspergillus, Penicillium e Fusarium são considerados importantes produtores de micotoxinas (NUNES et al., 2006; ATAYDE et al., 2014), que são metabólitos tóxicos naturais e frequentemente encontradas em alimentos. No entanto, podem causar intoxicação e problemas passageiros ou crônicos, que afetam várias funções do organismo, podendo causar alterações hepáticas, renais, circulatórias, no sistema nervoso e no trato digestivo, em animais, principalmente no ser humano, devido à ingestão destas substâncias (BOURGEOIS et al., 1994).

\section{MATERIAL E MÉTODOS}

\subsection{TIPO DE ESTUDO}

Trata-se de estudo transversal que segundo Fontelles et al. (2009), é um estudo realizado em um curto espaço de tempo em que se utiliza informações levantadas em um determinado ponto do tempo afim de se obter resultados rápidos e preciso sobre determinada investigação. Esse estudo por ser rápido é relativamente mais econômico.

3.2. LOCAL DO ESTUDO o local do estudo deu-se em uma instituição de ensino superior, localizada na cidade de Manaus, Amazonas, Brasil.

\subsection{COLETA E PROCESSAMENTO DAS AMOSTRAS BIOLÓGICAS}

Foram coletadas amostras de 10 placas de corte (figura 01). Para a coleta, utilizou-se o método de swab convencional, seguindo as recomendações de Andrade et al. (2008). O swab umedecido foi pressionado sobre a superfície de cada placa em movimentos giratórios ao longo de toda a sua extensão (frente e verso) (figura 02). Os swabs foram acondicionados em tubo falcon, contendo $10 \mathrm{~mL}$ de água peptonada a $0,1 \%$ estéril. Em seguida os tubos foram vedados e acondicionados, para posterior processamento das amostras. 
Figura 1. Placas de corte $(\mathrm{n}=10)$, utilizadas na pesquisa.

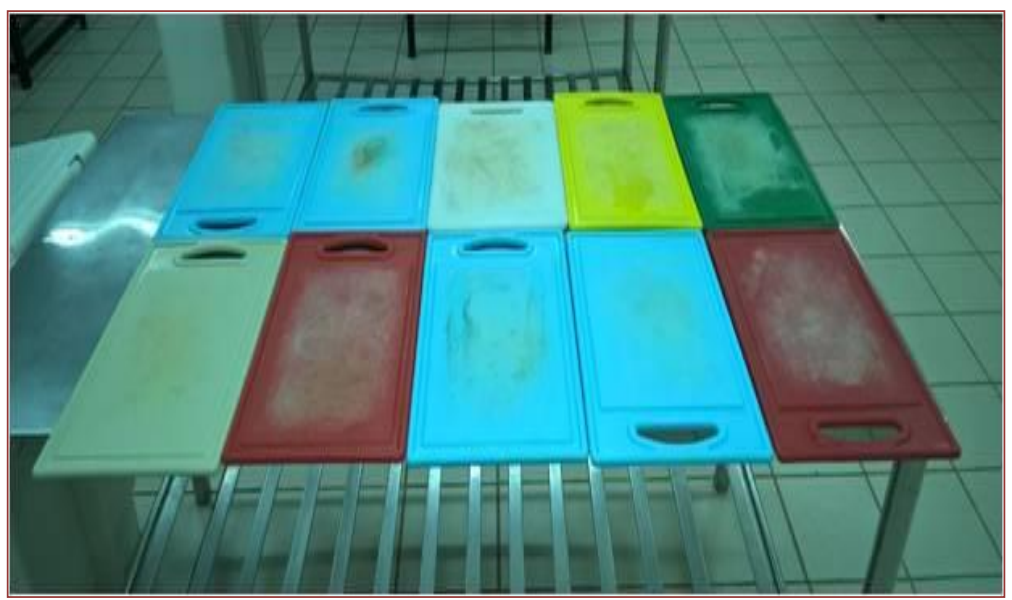

Fonte: Reis Silva, 2017

Figura 2. Representação do procedimento de coleta das amostras microbiológicas nas placas de corte.

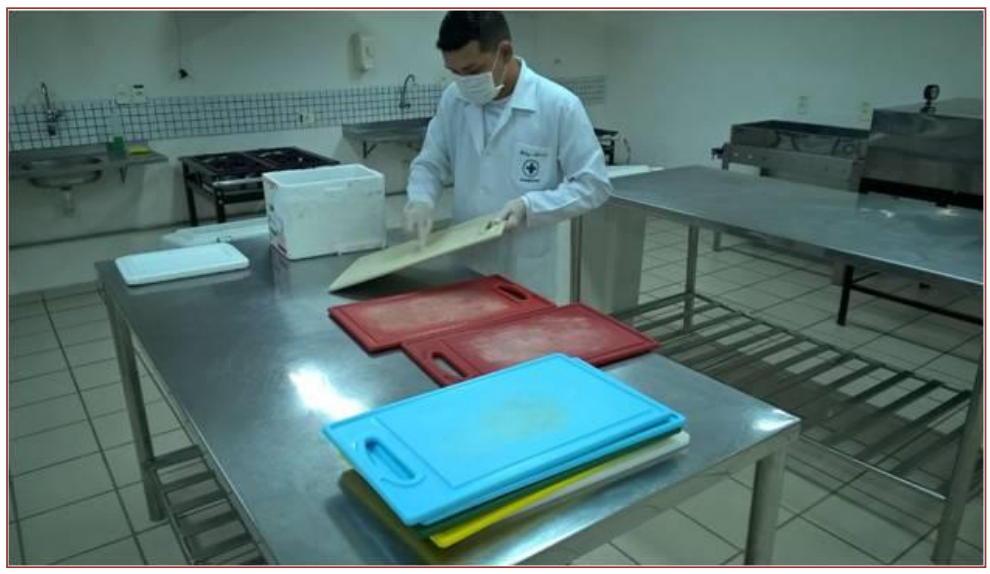

Fonte: Reis Silva, 2017

No Laboratório, no qual ocorreram as análises, os tubos contendo as amostras diluídas em água peptonada a 0,1 \% foram processadas conforme as características qualitativas definidas, seguindo as seguintes etapas: (1) para a contagem de mesófilos aeróbios, foi aplicado 0,1 mL de pré-inóculo sobre a superfície das placas de Petri, contendo o meio de cultura Plate Count Agar (PCA), seguida de incubação a $37 \stackrel{\circ}{\circ}$ por 48 h; (2) para análise de fungos (bolores e leveduras), aplicou-se 0,1 $\mathrm{mL}$ de pré-inóculo sobre as placas, contendo Ágar Sabouraud, as placas foram incubadas a $28^{\circ} \mathrm{C}$ por 5 dias e; (3) para a análise de enterobactérias, 0,1 mL do pré-inóculo foi aplicado na superfície das placas com Eosina Azul de Metileno Agar (EMB), seguido de incubação a 37 o C por $48 \mathrm{~h}$. Todas as análises foram realizadas em triplicata. As placas com os meios de cultivo PCA e EMB foram incubadas juntas na estufa bacteriológica, enquanto as amostras Inoculadas em Agar Saboraund foram incubadas em estufa B.O.D. própria para o crescimento de bolores e leveduras.

As coletas e a incubação para crescimento microbiológico das amostras foram realizadas no dia 05 de março de 2017. Após 48 horas, foram realizadas a contagem do número de colônias de bactérias que haviam crescido nos meios de cultivo. A contagem das colônias de bolores e leveduras foram feitas após 5 dias. 


\subsection{ANÁLISE DOS DADOS}

Os métodos aplicados na análise dos resultados, foram baseados nas regras de valores de referências usados para condições higiênico-sanitárias de equipamentos e utensílios utilizados no preparo de alimentos, proposto por Silva Júnior (2005), onde as unidades formadoras de colônias encontradas devem apresentar valores menor ou igual a $50 \mathrm{UFC} / \mathrm{cm}^{2}$, considerado valor satisfatório, porém, valores superiores a $50 \mathrm{UFC} / \mathrm{cm}^{2}$ são considerados insatisfatório.

O cálculo utilizado para expressar o número de $\mathrm{UFC} / \mathrm{cm}^{2}$, foi realizado de acordo com Pinheiro et al. (2010), onde foram multiplicados os números de colônias pelo inverso da diluição inoculada (UFC $/ \mathrm{cm}^{2}=$ № Colônia x $10 /$ diluição). 0 valor encontrado foi dividido pela área de $126 \mathrm{~cm}^{2}$, que representa o tamanho da superfície das placas de corte e expressa em unidades formadoras de colônia por $\mathrm{cm}^{2}\left(\mathrm{UFC} / \mathrm{cm}^{2}\right)$.

\section{RESULTADOS e DISCUSSÃO}

Um total de 10 amostras foram analisadas. Destas, 90\% apresentaram crescimento microbiano. Na tabela 1, estão os resultados de crescimento microbiano e a identificação qualitativa das colônias.

Cerca de 40\% das amostras avaliadas apresentaram colônias bacterianas aeróbias mesófilas com valores inferiores a $50 \mathrm{UFC} / \mathrm{cm}^{2}$, estas amostras foram consideradas satisfatórias quanto a presença deste grupo de micro-organismo. No entanto, $60 \%$ das amostras apresentaram resultado insatisfatório, pois os valores foram superiores a $50 \mathrm{UFC} / \mathrm{cm}^{2}$.

Tabela 1. Resultados dos crescimentos microbiológicos e grau de contaminação das placas.

\begin{tabular}{|c|c|c|c|c|c|c|}
\hline \multirow[t]{2}{*}{ Amostras } & \multicolumn{2}{|c|}{$\begin{array}{c}\text { Bactérias Aeróbias e } \\
\text { Mesófilas }\end{array}$} & \multicolumn{2}{|c|}{ Bolores e Leveduras } & \multicolumn{2}{|c|}{ Enterobactérias } \\
\hline & $\mathrm{UFC} / \mathrm{cm}^{2}$ & Classificação & $\mathrm{UFC} / \mathrm{cm}^{2}$ & Classificação & $\mathrm{UFC} / \mathrm{cm}^{2}$ & Classificação \\
\hline 1 & 97 & Insatisfatório & 182 & Insatisfatório & 181 & Insatisfatório \\
\hline 2 & 55 & Insatisfatório & 542 & Insatisfatório & 48 & Satisfatório \\
\hline 3 & 47 & Satisfatório & 385 & Insatisfatório & 70 & Insatisfatório \\
\hline 4 & 194 & Insatisfatório & 1034 & Insatisfatório & 245 & Insatisfatório \\
\hline 5 & 78 & Insatisfatório & 67 & Insatisfatório & 86 & Insatisfatório \\
\hline 6 & $\mathbf{0}$ & Satisfatório & 18 & Satisfatório & $\mathbf{0}$ & Satisfatório \\
\hline 7 & 32 & Satisfatório & 1768 & Insatisfatório & 43 & Satisfatório \\
\hline 8 & 377 & Insatisfatório & 97 & Insatisfatório & 491 & Insatisfatório \\
\hline 9 & 201 & Insatisfatório & 478 & Insatisfatório & 195 & Insatisfatório \\
\hline 10 & 14 & Satisfatório & 182 & Insatisfatório & 22 & Satisfatório \\
\hline
\end{tabular}


0 meio de cultura eosina azul metileno (EMB), utilizado no presente estudo, é seletivo para bactérias gram-negativas e os principais representantes do gênero são os coliformes totais pertencentes a família das Enterobacteriaceae. Aqui, foi observado em $60 \%$ das amostras a presença de colônias pertencentes ao grupo das enterobactérias, estas foram consideradas insatisfatória, enquanto a outras amostras apresentaram $40 \%$, sendo satisfatória. A identificação colônias de E. coli em meio de cultivo, torna-se possível pela apresentação verde metálico das colônias, conforme amostrado abaixo (figura 03).

Figura 2. Colônias de E. coli em placa de Petri, contendo o meio de cultura Eosina Azul Metileno.

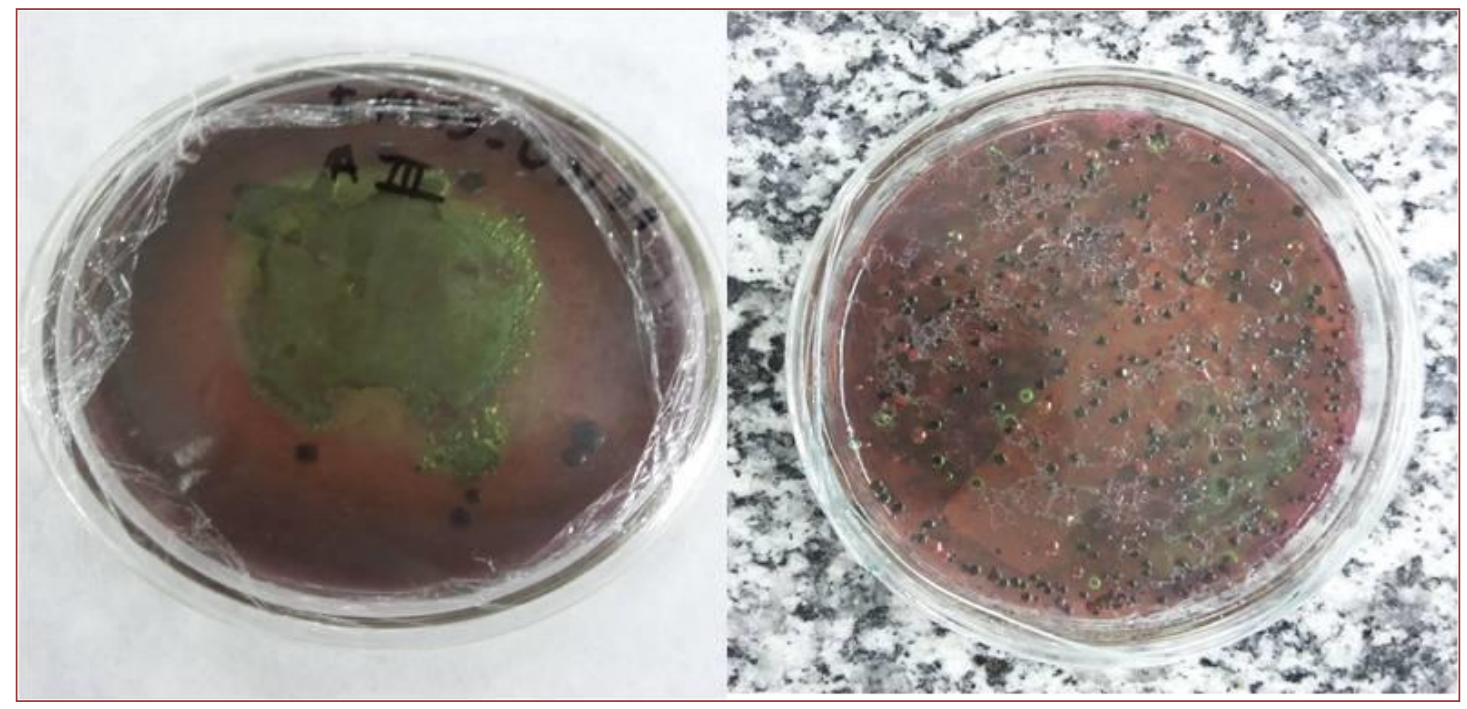

Fonte: Reis Silva, 2017

A pesquisa de bolores e leveduras mostrou um alto índice de contaminação por esses micro-organismos. $90 \%$ das superfícies analisadas mostraram resultados insatisfatório e somente $10 \%$ obtiveram resultados satisfatórios com crescimento inferior a $50 \mathrm{UFC} / \mathrm{cm}^{2}$. A figura 4 retrata o crescimento de bolores e leveduras em SDA Ágar.

Figura 3. Colônias de leveduras e bolores em placas de Petri, contendo o meio de cultura Ágar Sabouraud.

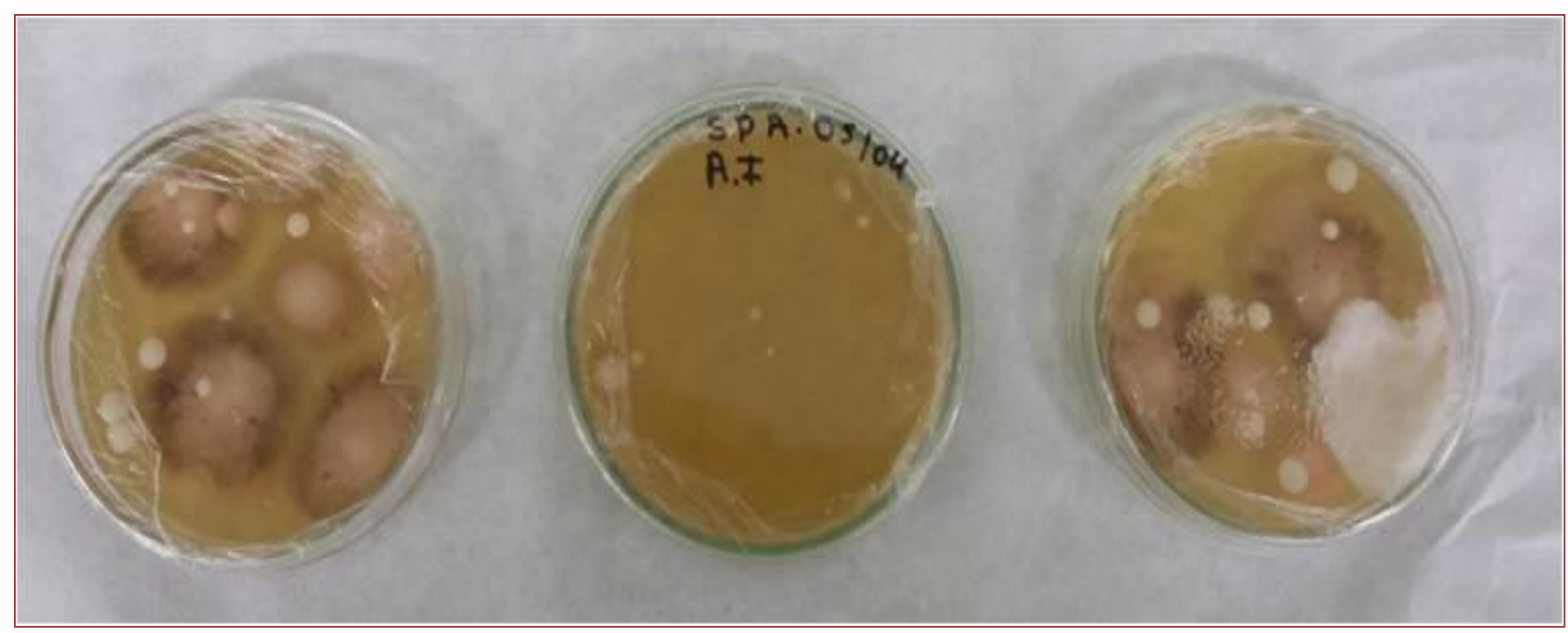


Neste estudo foi observado o crescimento microbiano em $90 \%$ das amostras analisadas. A detecção de microrganismos em superfícies de manipulação de alimentos infere que a limpeza do utensílio não foi realizada corretamente, que propicia o crescimento de bactérias, bolores e leveduras, aumentando o risco de contaminação cruzada (SILVA-JUNIOR, 2005).

As bactérias aeróbias mesófilas não causam mudanças morfológicas ou organolépticas no alimento e nem são causadoras de toxi-infecções alimentares, porém a presença dessas formas microbianas acima dos valores permitidos, apontam condições higiênicos-sanitárias de má qualidade. Como são encontradas comumente nos ambientes, indicam que os alimentos não foram lavados ou armazenados corretamente, ou que sofreram contaminação cruzada, por meio de utensílios não higienizados. (SILVAJÚNIOR 2005; AGUIAR, 2006; FRANCO e LANDGRAF, 2008).

Foi possível também, detectar formas bacterianas similares ao grupo das enterobactérias (60\%) neste estudo. Saber-se que a $E$. coli é o mais comum e um dos principais membros das Enterobacteriaceae, sendo as mesmas enteropatógenos causadores de doenças do trato gastrointestinais, possuindo uma grande variedade de fatores de virulências e dependo da cepa em questão, podem causar diversos danos ao organismo humano.

A família das Enterobacteriaceae possui uma grande variedade de espécies e está dividida em dois grupos: os coliformes totais e os coliformes termotolerantes. São considerados microrganismos ubiquitários, e representam o principal grupo de enteropatógenos causadores de infecções no homem, o que faz dessas bactérias o maior e mais importante grupo de microrganismos de importância médica (MURRAY et al., 2009).

Os coliformes totais fermentam lactose em temperaturas de até $37 \stackrel{\text { o}}{ } \mathrm{C}$, são encontrados no material intestinal dos animais e em solo, água e alguns vegetais e como são bactérias que habitam o ambiente resistem por mais tempo do que bactérias patogênicas de origem intestinal, logo a sua presença não qualifica contaminação de material fecal recente (FRANCO e LANDGRAF, 2008).

Já os coliformes termotolerantes, são capazes de fermentar a lactose em temperaturas de até $45,5 \stackrel{\circ}{\circ} \mathrm{C}$, e seu principal representante é a $E$. coli. Enquanto o crescimento de coliformes totais não indica seguramente a possível presença de resquícios entéricos, o crescimento de coliformes termotolerantes indica seguramente a contaminação por material fecal, uma vez que nessas condições de temperaturas eles conseguem se reproduzir continuamente, se sobrepondo aos outros gêneros (SILVAJÚNIOR, 2005; FRANCO e LANDGRAF, 2008).

Outros micro-organismos detectados nessa pesquisa, foram os bolores e as leveduras. Estes fungos não possuem a capacidade de causar doenças gastrointestinais, mas são os principais agentes deteriorantes de alimentos. A presença dos mesmos indica que as placas estão sendo armazenadas úmidas, promovendo assim o crescimento contínuo desses fungos, logo, o risco de contaminação dos alimentos processados sobre as superfícies aumenta consideravelmente por contaminação cruzada (PINHEIRO et al., 2010).

Um estudo realizado em tábuas de corte de madeira mostrou contaminações significativas por bactérias, sendo esses microrganismos os principais causadores de infecções associadas a alimentos contaminados, isso mostra a grande facilidade de 
aderência nas fissuras existentes na superfície originadas do uso contínuo das tábuas. Essas fissuras dificultam a higienização, levando a proliferação de microrganismos nessas tábuas (ABREU, 2005).

Segundo Ávila (2010) em pesquisa realizada com 28 participantes sobre o conhecimento de condições higiênicos-sanitárias no processo de manipulação de alimentos, 82,1\% afirmaram não lavar as superfícies de corte antes de utilizá-las no preparo do alimento, mostrando a falta de conhecimento de manipuladores quanto a boas práticas de higiene de utensílios usados no preparo de alimentos. Outro estudo realizado em placas de corte de uma instituição de ensino superior em São Carlos, SP, constatou um resultado alarmante de $90 \%$ de contaminação das amostras por mesófilos aeróbios, bolores, leveduras e enterobactérias (PINHEIRO et al., 2010).

Um estudo conduzido por Welker et al. (2009) em alimentos envolvidos em casos de DTA's no estado do Rio Grande do Sul, apontou que 66\% das amostras analisadas apresentaram resultados positivos para a presença de Enterobactérias, o que pode levar a associação desses micro-organismos nos casos relatados de DTA's.

A não utilização de boas práticas para a preservação de utensílios usados na manipulação de alimentos, leva a condições higiênicos-sanitárias precárias dos mesmos, como visto na pesquisa onde $90 \%$ das amostras de superfícies estudadas apresentaram resultados insatisfatório para a presença de micro-organismos o que aumenta os riscos de contaminações dos alimentos levando a toxi-infecções alimentares e a degradação acelerada do produto.

\section{CONCLUSÃO}

Neste estudo preliminar, foi constatado a presença de formas bacterianas aeróbias mesófilas em $90 \%$ das placas de manipulação de alimento, além da detecção de representantes da família Enterobacteriaceae e de fungos. Baseado nestes resultados, acredita-se que as placas utilizadas nos laboratórios-cozinha não estão sendo higienizados e armazenados corretamente.

Estes dados precisam ser aprimorados, por meio de isolamento dos microorganismos em meio de cultura específico e identificação por técnicas bioquímicas e moleculares. No entanto, servem de alerta à comunidade acadêmica e aos gestores da instituição, para o desenvolvimento de ações que promovam a boa prática de pessoas diretamente envolvidas no processo de produção de alimentos. 


\section{REFERÊNCIA}

ABREU, C. S.; CABRAL, W. M. M. Análise microbiológica de placas de corte de madeira para identificação de bactérias pertencentes ao grupo das Enterobacteriaceae. Revista. Cientifica da universidade de Franca.5 (1/6): 132-138. 2005.

AFONSO, Anabela. Metodologia Haccp. Segurança e Qualidade Alimentar.1: 12-15. 2006.

AGUIAR, C. Implementação de boas práticas de manipulação em uma creche do município de São Paulo. Cadernos. Centro Universitário S. Camilo, São Paulo. 12 (1): 4757. 2006.

ANDRADE, N. J.; A. S. Higiene na indústria de alimentos: Avaliação e Controle da Adesão e Formação de Biofilmes Bacterianos. São Paulo: Varela. 181-226. 2008.

ATAYDE, H. M.; OLIVEIRA, I. M. A.; INHAMUNS, A. J.; TEIXEIRA, M. F. S. Fungos toxigênicos e micotoxinas na alimentação de peixes: uma revisão. ScientiaAmazonia. 3 (3): 59-71. 2014

ÁVILA, R.; ANDRADE, R. B.; MACHADO, D. R. J.; RABELO, R. P.; SILVA, M. R. Práticas higiênico-sanitárias na manipulação de alimentos: diagnóstico e intervenção. Com. Ciências Saúde, Goiânia. 21 (2): 117-124. 2010.

BOURGEOIS, C. M.; MESCLE, J. F.; ZUCCA, J. Microbiología Alimentaria: Aspectos microbiológicos de la seguridade y calalidad alimentaria. 1. ed. Zaragoza: Editorial ACRIBIA, S.A. 1994.

BRASIL. Agência Nacional de Vigilância Sanitária. Resolução RDC N. 12, de 02 de janeiro de 2001. Regulamento Técnico sobre Padrões Microbiológicos para Alimentos. Diário Oficial da União. Brasília, 10 jan. 2001.

BRASIL. Ministério da Saúde. Manual integrado de vigilância, prevenção e controle de doenças transmitidas por alimentos. 2. ed. Brasília. 2010.

BRASIL. Portaria no 518, de 25 de março de 2004. Disponível em: <http://elegis.anvisa.gov.br/leisref/public/showAct.php? id $=22322 \&$ word=>. Acesso em: 20 fevereiro de 2017.

CENTER FOR DISEASE CONTROL AND PREVENTION. FOOD SAFETY. Foodborne Illnesses and Germs. Disponível em: https://www.cdc.gov/foodsafety/foodbornegerms.html Acesso em: 22 nov. 2018.

CHOUMAN, K.; PONSANO, E. H. G.; MICHELIN, A. F. Qualidade microbiológica de alimentos servidos em restaurantes self-service. Revista. Instituto Adolfo Lutz. São Paulo. 69 (2): 261-266. 2010.

FLORES, A. M. P. C.; MELO, C. B. Principais bactérias causadoras de doenças de origem alimentar. Revista Brasileira de Medicina Veterinária. 37: 65-72. 2015.

FONTELES, J. M.; SIMÕES, M. G.; FARIAS, S. H.; FONTELLES, R. G. S. Metodologia da pesquisa científica: diretrizes para a elaboração de um protocolo de pesquisa. Núcleo de Bioestatística Aplicado à pesquisa da Universidade da Amazônia - UNAMA. 2009. 
FORSYTHE, S. J. Microbiologia da Segurança dos Alimentos. 2.ed. Porto Alegre: Artmed. 2013.

FRANCO, B. D. G. M.; LANDGRAF, M. Microbiologia dos alimentos. São Paulo: Atheneu. 381. 2008.

JAY, M. J. Microbiologia de alimentos. Porto Alegre: Artmed. 6: 53-57. 2005.

MARCHI, D. M.; BAGGIO, N.; TEO, C. R. P. A.; BUSATO, M. A. Ocorrência de surtos de doenças transmitidas por alimentos no município de Chapecó, estado de Santa Cataria, Brasil, no período de 1995 a 2007. Epidemiologia e Serviços de Saúde. 20: 401-407. 2011.

MINISTÉRIO DA SAÚDE. Surtos de Doenças Transmitidos por Alimentos no Brasil. Maio de $2017 . \quad$ Disponível em: http://portalarquivos.saude.gov.br/images/pdf/2017/maio/29/Apresentacao-SurtosDTA-2017 Acesso em: 22 nov. 2018.

MURRAY. PR.; ROSENTHAL. K.S.; PFALLER. M.A. Microbiologia médica. Rio de Janeiro, Elsevier. 299-313. 2009.

NOTERMANS, S.; NAUTA, M. J.; JANSEN, J.; JOUVE, J. L.; MEAD, G. C. A risk assessment approach to evaluating food safety based on product surveillance. Food Control, Guildford. 9 (4): 217-223. 1998.

NUNES, I. L.; MAGAGNIN, G.; ELITA, B. T.; BADIALE-FURLONG, E. Arroz comercializado na região sul do Brasil: aspectos micotoxicológicos e microscópicos. Ciênc. Tecnol. Aliment., Campinas. 23 (2): 190-194. 2003.

OLIVEIRA, A. B. A.; PAUlA, C. M. D.; CAPAlOnGA, R.; CARDOSO, M. R. I.; TONDO, E. C. Doenças transmitidas por alimentos, principais agentes etiológicos e aspectos gerais: uma revisão. HCPA: 30: 279-285. 2010.

PINHEIRO, B. M.; WADA, C. T.; PEREIRA, C. Análise microbiológica de tábuas de manipulação de alimentos de uma instituição de ensino superior em São Carlos, SP. Revista. Simbio-Logia. 3 (5): 115-124. 2010.

RAVEN, P. H.; EVERT, R. F.; EICHHORN, S. E. Biologia Vegetal. 6. ed. Rio de Janeiro: GUANABARA KOOGAN S.A. 2001.

ROQUE-SPECHT, V. F.; CASTRO, J. E. E.; NETO, M. F. GEPROS. Gestão da Produção, Operações e Sistemas. 2 (4): 37-48. 2007.

ROSSI, C. F. Condições higiênico-sanitárias de restaurantes comerciais do tipo selfservice de Belo Horizonte-MG. Dissertação (Mestrado em Ciência de Alimentos) Faculdade de Farmácia da Universidade Federal de Minas Gerais. Belo Horizonte. 142p. 2006.

SCHOTHORST, M. V. principles for the establishment of microbiological food safety objectives and related control measures. Food Control, Guildford. 9 (6): 379-384. 1998. 
SILVA-JÚNIOR, E. A. Manual de controle higiênico-sanitário em serviços de alimentação. São Paulo: Varela. 6: 624. 2005.

SILVA, J. C. G.; SILVA FILHO, M. M.; NASCIMENTO, G. V.; PEREIRA, D. A. B.; COSTA JÚNIOR, C. E. O. Incidência de doenças transmitidas por alimentos (DTA) no estado de Pernambuco, um acompanhamento dos dados epidemiológicos nos últimos anos. Ciências Biológicas e de Saúde UNIT. 3: 23-34. 2017.

SOARES, A. G.; OLIVEIRA, A. G. M.; FONSECA, M. J. O.; FREIRE, M. J. Boas práticas de manipulação em bancos de Alimentos. Documentos 74. Embrapa Agroindústria de Alimentos, Rio de Janeiro. 2006.

VERBENO, B.; GOMES, C. R.; FURTADO, C. R. S.; BRASIL, L. S. N. S.; MARQUES, S. S. F. Condutas de risco de consumidores em restaurantes self service do centro comercial de Belém-PA. Disponível em: <http://www.fabsoft.cesupa.br/sabernutrição/artigos/edição1/artigo6_CONDUTAS> Acesso em: 22 de fevereiro e 2017.

WELKER, D. A. C.; BOTH, J. M. C.; LONGARAY, S. M.; HAAS, S.; SOEIRO, M. L. T.; RAMOS, R. C. Análise microbiológica doas alimentos envolvidos em surtos de doenças transmitidas por alimentos (DTA) no estado do Rio Grande do Sul, Brasil. Revista. Bras. Bioci. 8 (1): 44-48. 2010.

WILLIAMS, S. Chefs: técnica e equipamentos. 01.ed. São Paulo: Melhoramentos. 48-49. 2011. 


\section{Capítulo 17}

\section{Análise bacteriológica de balaústres de ônibus utilizados no transporte público de Manaus}

\section{Heraldo de Oliveira Alves \\ Liliane Coelho da Rocha \\ Sabrina da Fonseca Meireles \\ Francimeire Gomes Pinheiro}

Resumo: A locomoção diária da população nas grandes metrópoles ocorre via transporte coletivo. Esses ambientes quando não higienizados corretamente servem de reservatórios de diversos tipos de microrganismos e podem causar doenças. Diante dessa problemática, foi realizada uma análise microbiológica de balaústres em duas rotas de ônibus, uma hospitalar e outra não hospitalar na cidade de Manaus-AM. As amostras ( $\mathrm{n}=16)$ foram coletadas, e os microrganismos foram isolados e identificados. Foi observado na maioria das amostras, Bacilos Gram-Negativos, com distribuição e ocorrência em toda a extensão do veículo nas duas rotas de ônibus analisadas e, o grupo Estafilococos foi o menos frequente de Gram-Positivos. Estes dados confirmam a importância da adoção de boas práticas de higienização diariamente nesses transportes e, principalmente, a higiene pessoal da população, como a lavagem das mãos após o uso desse serviço, visando minimizar a contaminação, infecções cruzadas e a alta taxa de morbidade de doenças causadas por bactérias patogênicas.

Palavras-chave: Contaminação, Reservatório de doenças, Transporte coletivo. 


\section{INTRODUCĈ̃O}

A cidade de Manaus, capital do Estado do Amazonas, é o principal polo econômico da Região Norte do Brasil. É uma cidade histórica, localizada no centro da maior floresta tropical do mundo na confluência dos Rios Negros e Solimões, com uma área territorial de $11.401 .092 \mathrm{~km}^{2}$ e uma população média estimada em 2020, de aproximadamente 2.219.580 habitantes, sendo considerada uma das principais cidades metropolitana do Norte do país (BRASIL; IBGE, 2020).

Contundo, não fugindo das semelhanças e distinções das grandes metrópoles brasileiras, cuja locomoção diária da população em sua maior parte, ocorre via transporte coletivo, Manaus vem sofrendo impactos no sistema de mobilidade, principalmente nas áreas já estruturadas mais centrais da cidade (MEYER e GROSTEIN, 2006). Existem dez empresas concessionárias que operam com cerca de 1620 veículos, em 221 linhas, e realizam em média 10.000 viagens por mês, nos cinco terminais centrais da cidade, aonde circulam diariamente um total de 188 mil usuários (PLANMOBMANAUS, 2015).

0 transporte público é um ambiente compartilhado e pode servir como foco de dispersão de inúmeros microrganismos etiológicos, principalmente por meio da contaminação das mãos dos passageiros em contato com corrimãos de ônibus na entrada e saída, seguido do contato com a boca, podendo estabelecer um ciclo oral-fecal de várias doenças bacterianas e parasitárias (ALVES, 2010). As bactérias adentram o organismo de várias formas, seja por via oral, nasal, inoculadas por picadas de insetos e agulhas, relações sexuais e feridas expostas, mas só desencadeiam um processo infeccioso em condições de desequilíbrio fisiológico (GOMES et al., 2016; FERNANDES et al., 2012).

A Escherichia coli é uma das bactérias comumente encontradas em superfícies contaminadas e está relacionada à diarreia, sendo também utilizada como indicador das condições higiênico-sanitárias no ambiente; as do gênero Staphylococcus sp., também compõem a microbiota humana e é frequentemente associadas às infecções cutâneas de pele (RODRIGUES et al., 2006); enquanto as Pseudomonas sp. apresentam grande ameaça para pacientes hospitalizados por serem patógenos oportunistas (MENEZESSILVA e NEUFELD, 2006).

Considerando a precariedade do transporte público de Manaus, assim como a falta de higienização diária dos ônibus e a superlotação, objetivou-se diante dessa problemática, a realização de uma análise microbiológica em balaústres de duas rotas de ônibus da cidade de Manaus, a fim de contribuir com dados microbiológicos que possam esclarecer à sociedade sobre a importância da prática de lavagem das mãos como medida profilática, para evitar a contaminação com microrganismos que causam doenças infecciosas em ambiente público.

\section{REFERENCIAL TEÓRICO}

\subsection{MOBILIDADE URBANA E TRANSPORTE PÚBLICO DE MANAUS}

O transporte urbano (ou transporte público, ou transporte coletivo) por definição da Política Nacional de Mobilidade Urbana (2012), é o “conjunto dos modos e serviços de transporte público e privado utilizados para o deslocamento de pessoas e cargas nas cidades integrantes da Política Nacional de Mobilidade Urbana". O transporte de passageiros é uma das maiores necessidades sociais da atualidade, é um serviço 
essencial pela constituição brasileira e os usuários têm o direito de receber um serviço adequado às suas necessidades (BUBICZ e SELLITTO, 2009).

Na cidade de Manaus, o transporte público até o início da década de 50 era realizado por bondes elétricos. No entanto, para atender a crescente demanda da população, houve a necessidade de implantação do sistema de ônibus (MAGALHAES, 2011), que foi ampliado após o boom de crescimento desordenado com a implantação da Zona Franca de Manaus (ZFM) em 1967. Em 2015, a cidade de Manaus com seus mais de 2 milhões de habitantes, constava de apenas 1620 ônibus (SMTU, 2015), frota insuficiente para atender a população.

Na Constituição Federal de 1988, o transporte de passageiros é responsabilidade municipal. É do município o deve de estabelecer condições técnicas, requisitos de segurança, higiene e conforto dos veículos destinados a este fim, conforme o Código de Trânsito Brasileiro de 1997. Portanto, o transporte coletivo deve ser um provedor, eficaz e democrático, de mobilidade e acessibilidade urbana, cujo desenvolvimento deve-se considerar o uso do solo, as políticas de planejamento urbano e de qualidade ambiental (DUARTE et al., 2012).

\subsection{MICRORGANISMOS UBÍQUOS}

Em todo o planeta, os microrganismos representam a forma de vida mais diversificada e abundante (WHITMAN et al., 1998). Em sua maioria não causam malefícios, sendo considerados patogênicos apenas 3\% de todo seu leque de espécies (GOMES et al., 2016). Dentre estes, as bactérias são os mais comuns, podendo viver associados aos animais por meio de relações comensais e simbióticas na maioria das vezes, mas também fungos, archaea e vírus podem estar associados (ARUMUGAM et al., 2011; CORDEIRO et al., 2017).

As bactérias e fungos fazem parte da microbiota do corpo humano, podendo ser inofencivas a depender do local de colonização e quantidade. A função desses microrganismos na absorção de nutrientes e proteção contra agentes infecciosos é de grande importância, porém, quando há alteração neste equilíbrio, podem causar prejuízos ao hospedeiro, levando ao desenvolvimento de infecções graves (MACHADO, 2008). A microbiota do trato gastrointestinal (TGI) humano é o sítio orgânico mais densamente povoado por bactérias (ARUMUGAM et al., 2011), abrigando dez vezes mais bactérias que o número de células que formam nosso organismo (QIN et al., 2010).

A Escherichia coli é uma bactéria Gram negativa que vive de maneira comensal no intestino humano e de animais (BRIDLE, 2014). No entanto, quando presente em outras partes do corpo, pode causar graves infecções do trato urinário, meningite e septicemia (MURRAY et al., 2009). O gênero Klebsiella spp. também apresenta bactérias Gram negativa e está associado a infecções adquiridas em unidade de terapia intensiva neonatos (UTI), sendo um importante agente causador da sepse, meningite, infecções urinárias, pneumonia e infecções articulares (GRUPTA, 2002; ROILIDES et al, 2000). Por fim, Bacillus spp. são as formas bacterianas mais comuns e ubíquas, sendo os Bacillus antrhacis, causador de anthrax cutâneo, intestinal e pulmonar; e o Bacillus cereus, causador de necrose ou gangrena em partes moles, intoxicação alimentar, infecções pulmonares, entre outros quadros clínicos (BRASIL, 2004). 


\subsection{TRANSPORTE PÚBLICO COMO DEPÓSITO DE MICRORGANISMOS}

A presença de micro-organismos em superfícies de ambientes domiciliares e domésticas demonstra que qualquer tipo de ambiente está suscetível a contaminação. Em ambientes públicos com alta densidade de circulação de pessoas, a higienização diária desses locais é fundamental. Estudos mostram a contaminação de objetos inanimados e superfícies como elementos veiculadores de microrganismos, seja de ambientes hospitalares ou não. Em feiras livres, por exemplo, já foi identificado bactérias patogênicas em cédulas circulantes (FERREIRA et al., 2012). Em contanto com ambientes contaminados, as pessoas acabam atuando como receptores de microrganismos, tornando-se fonte de contaminação própria e disseminadora para outros (RODRIGUES et al., 2006).

Certos microrganismos são infecciosos em quantidades relativamente pequenas, podendo ser isolados depois de prolongados períodos sobre superfícies inanimadas, como telefones, crachás de identificação, maçanetas, cédulas de dinheiro e demais objetos que sirvam de fômites (YALOWITZ et al., 2003; WILSON et al., 2007; SILVA et al., 2014). Em transporte público não é diferente. As estruturas internas, como os assentos e alças do teto de ônibus, podem ser um meio de propagação de microrganismos (SOUZA et al., 2020). Em alças de teto de ônibus de duas rotas do transporte coletivo de Curitiba, Paraná, foram isoladas as espécies de bactérias Staphylococcus saprophyticus, Staphylococcus liquefaciens e Escherichia coli (RODRIGUES et al., 2006). E em Juazeiro do Norte-CE, em ônibus de rotas municipais foram identificados bactérias dos gêneros: Bacillus spp., Klebsiella spp., Escherichia spp. e Enterobacter spp. além de fungos como bolor e leveduras (CORDEIRO et al., 2017).

\section{MATERIAL E MÉTODOS}

\subsection{LOCAL DO ESTUDO}

0 estudo foi realizado no município de Manaus, Amazonas, no período correspondente ao mês de março de 2016, em duas empresas de ônibus que prestam serviço no transporte coletivo urbano. As amostras foram coletadas de quatro veículos, dos quais, dois fazem rota da zona oeste a sul (rota hospitalar) e os outros dois fazem a rota da zona norte à oeste (rota não hospitalar).

\subsection{CRITÉRIO DE INCLUSÃO DAS ROTAS DE ÔNIBUS}

Foram selecionados quatro veículos de mesmo tamanho e comprimento básico (modelo Padron) de duas rotas, sendo dois ônibus com itinerário contendo uma rota hospitalar e dois ônibus com itinerário sem rota hospitalar. As duas rotas tiveram itinerário de quilometragem média de 57 a 62 quilômetros, e cerca de 230 passageiros por viagem. 


\subsection{DETALHES DA ROTA HOSPITALAR}

A "rota hospitalar" teve como ponto de partida, o bairro Santo Agostinho (zona oeste) e ao longo do percurso, passou por várias unidades de sáude, a saber: Pronto Socorro da Criança; Maternidade Moura Tapajós; Posto de Saúde Leonor de Freitas (UBS); Centro de Atenção ao Idoso (CAIME); Centro de Atenção Integral a Criança (CAIC); Escola Superior de Ciências da Saúde da UEA; Fundação Hospital Adriano Jorge (FHAJ) e; Fundação Alfredo da Matta (FUAM). Ademais, a rota interliga Manaus a outros municípios, como: Manaquiri, Careiro Castanho e Careiro da Várzea, pois tem como terminal de parada final, o Porto da Ceasa (zona sul), onde atracam balsas, lanchas e recreios (embarcação que transportam pessoas e cargas de pequeno porte).

\subsection{DETALHES DA ROTA NÃO HOSPITALAR}

A "rota não hospitalar" teve como ponto de partida o bairro Ponta Negra (zona oeste) e foi até ao Terminal três (T3), localizado no bairro da Cidade Nova (zona norte), ao longo do trajeto passou apenas por bairros convencionais e conjuntos sem unidades de saúde nas proximidades do seu itinerário.

\subsection{COLETA DAS AMOSTRAS}

As coletas no interior dos veículos foram realizadas nos balaústres da porta de entrada (figura 1A), da porta de saída (figura 1B), e nos balaústres horizontais e verticais (figura 2), visto que esses locais apresentam maior possibilidade de contato com as mãos. 0 horário de coleta das amostras foi a partir das 14:00 horas, nos pontos finais das rotas.

Figura 1. A- balaústre da porta de entrada; B- balaústre da porta de saída. As setas indicam os balaústres de onde foram realizadas as coletas.

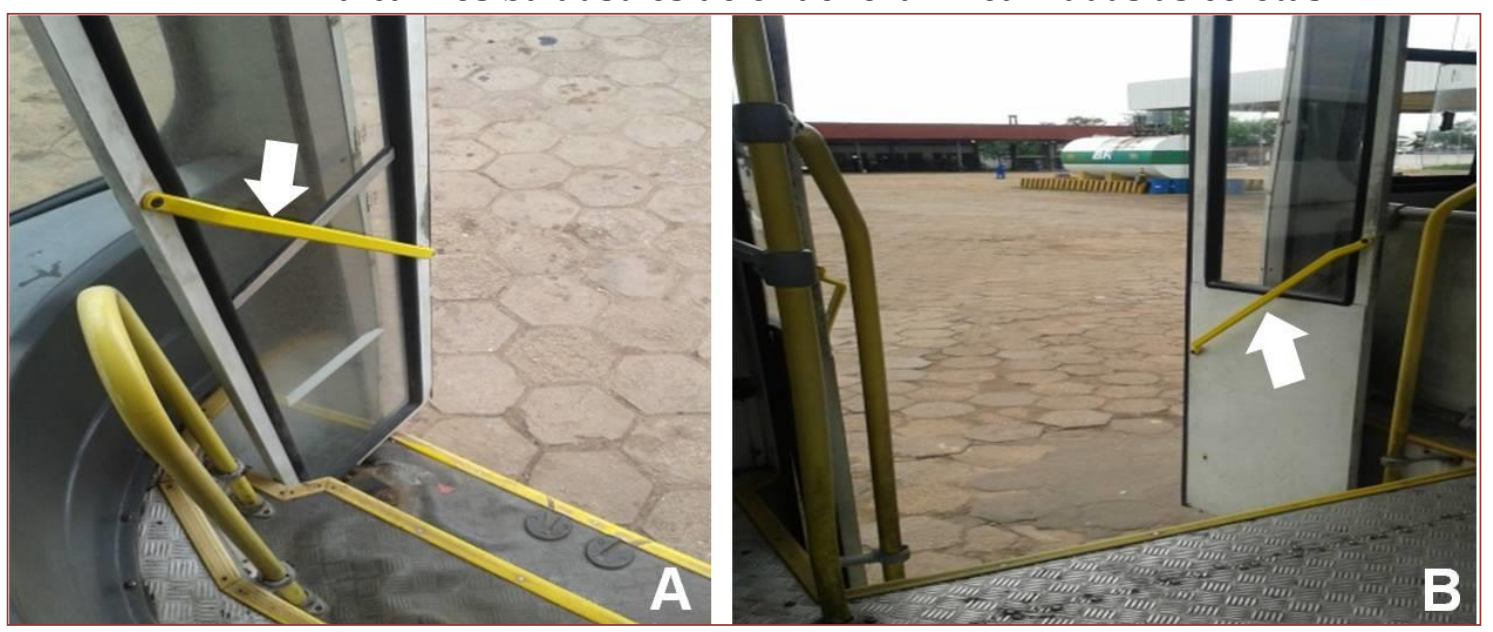

Fonte: Alves (2016) 
Figura 2. Balaústres horizontal e vertical, indicados pelas setas.

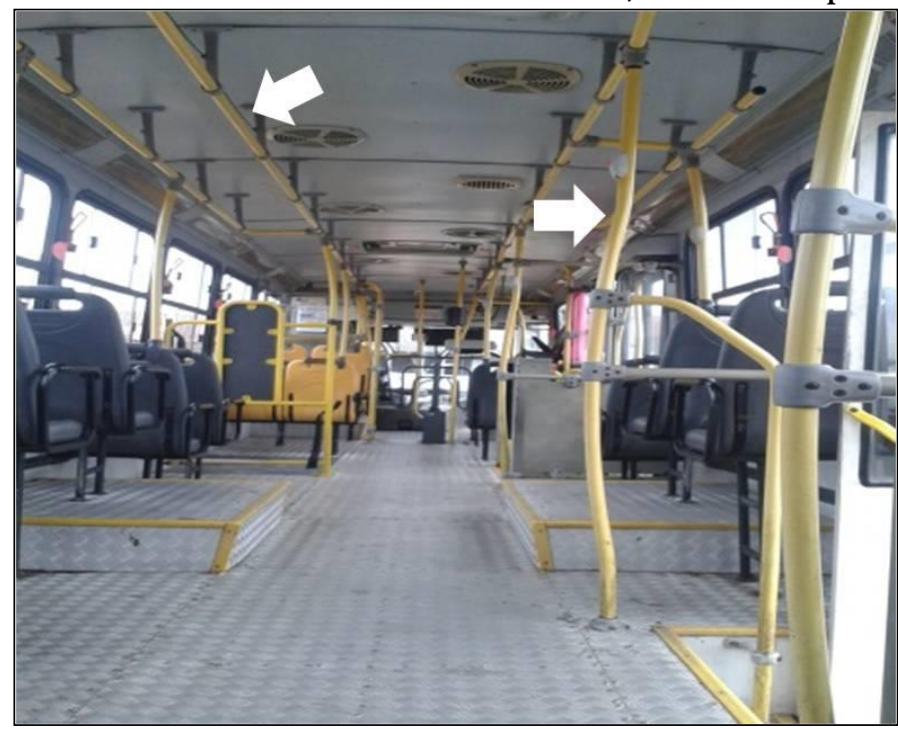

Fonte: Alves (2016).

\subsection{ISOLAMENTO E IDENTIFICAÇÃO DAS BACTÉRIAS}

As coletas das amostras foram realizadas com auxílio de swab, contendo o meio Stuart. Os procedimentos foram realizados no mesmo dia, em temperatura de $31^{\circ} \mathrm{C}$ e umidade do ar a 71\%, com tempo chuvoso.

As amostras foram semeadas em placas de Petri com quatro diferentes tipos de meio de cultura, a saber: Ágar Mueller Hinton (MH) BD®; Ágar Eosina Azul de Metileno (EMB) PRODIMOL®; Ágar Salmonela Shigella (SS) HIMEDIA®; e Ágar Chocolate (AC), para permitir o crescimento de bactérias Gram positivas e Gram negativas, conforme a metodologia proposta por Menezes-Silva e Neufeld (2006).

As amostras foram semeadas em em placas de Petri em câmara de fluxo laminar (VECO $\left.{ }^{\circ}\right)$ no laboratório de Leishmaniose e Doença de Chagas do Instituto Nacional de Pesquisas da Amazônia (INPA). Em seguida, as placas foram incubadas a $36^{\circ} \mathrm{C}$ em estufa BOD por um período de 24 a 48 horas, após esse período, os meios foram observados de forma macroscópica para avaliar se houve crescimento bacteriano no substrato, por meio da morfologia das colônias.

\subsection{COLORAÇÃO DE GRAM E LEITURA DAS LÂMINAS}

A coloração das colônias em lâminas foi realizado de acordo com o método proposto por Menezes-Silva e Neufeld (2006). Após coloração, as lâminas foram lavadas com água destilada e analisadas em microscópio de luz com objetiva de 100X em óleo de imersão.

As bactérias foram identificadas de acordo com suas estruturas (cocos e bacilos) e arranjos (estafilococos em cachos, estreptococos em formato de colar ou em cadeia, diplococos em pares, diplobacilos em pares, estreptobacilos em formato linear ou colar de bastonetes e cocobacilos, com forma oval) (MENEZES-SILVA e NEUFELD, 2006). 


\section{RESULTADOS E DISCUSSÃO}

As amostras semeadas $(\mathrm{n}=16)$ obtidas de balaústres de quatro ônibus em Manaus, resultaram no isolamento de bactérias em 100\% das placas dos meio $\mathrm{MH}, \mathrm{AC}$ e EMB. No meio ASS apenas $50 \%$ das placas foram positivas para crescimento de microrganismos (figura 3). Em $50 \%$ de todas as placas positivas cresceram apenas um tipo de colônia e nos outros 50\%, de duas a quatro colônias. Ainda foi observado o crescimento de leveduras em duas placas de meio $\mathrm{MH}$.

Figura 3. Percentual de crescimento bacteriano nos meios de cultura utilizados no estudo. AC: Ágar chocolate, BEM: Ágar Eosina Azul de Metileno, SS: Salmonella- Shigella, MH: Ágar Muller Hinton.

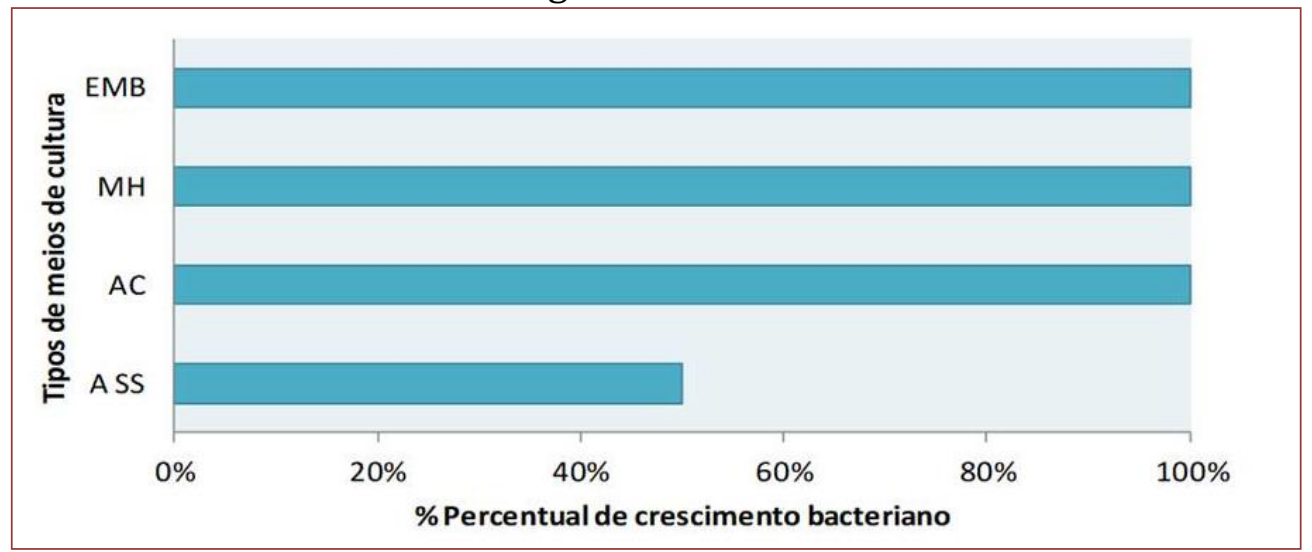

Na tabela 1 está discriminada os tipos de bactérias encontradas na rota não hospitalar e na tabela 2 , as bactérias isoladas da rota hospitalar.

Tabela 1. Dados do Teste Morfotintorial dos ônibus da rota não hospitalar.

\begin{tabular}{|l|l|l|l|}
\hline \multicolumn{4}{|c|}{ *LOCAIS DE COLETA NO ÔNIBUS } \\
\hline \multicolumn{1}{|c|}{ BPE } & \multicolumn{1}{|c|}{ BV } & \multicolumn{1}{c|}{ BH } & \multicolumn{1}{|c|}{ BPS } \\
\hline Bacilos Gram - & Bacilos Gram - & Bacilos Gram - & Bacilos Gram - \\
Estreptobacilos Gram - & Cocos Gram - & Diplobacilos Gram - & Diplobacilos Gram - \\
& Cocos Gram + & Estreptobacilos Gram & Estreptobacilos Gram - \\
& Estafilococos Gram + & - & $\begin{array}{l}\text { Diplococos Gram - } \\
\text { Estafilococos Gram + }\end{array}$ \\
& & Diplococos Gram - & Estafilococos Gram + \\
& & \\
\hline
\end{tabular}

${ }^{*} \mathrm{BPE}=($ Balaústre da porta de entrada $), \mathrm{BV}=($ Balaústre vertical $), \mathrm{BH}=($ Balaústre horizontal $), \mathrm{BPS}=$ (Balaústre da porta saída).

Tabela 2 - Dados do Teste Morfotintorial dos ônibus da rota hospitalar.

\begin{tabular}{|l|l|l|l|}
\hline \multicolumn{4}{|c|}{ *LOCAIS DE COLETA NO ÔNIBUS } \\
\hline \multicolumn{1}{|c|}{ BPE } & \multicolumn{1}{|c|}{ BV } & \multicolumn{1}{c|}{ BH } & \multicolumn{1}{c|}{ BPS } \\
\hline Bacilos Gram - & Bacilos Gram - & Bacilos Gram - & Bacilos Gram - \\
Diplobacilos Gram - & Diplobacilos Gram - & Diplobacilos Gram - & Diplobacilos Gram - \\
Cocos Gram + & Estreptobacilos & Diplococos Gram + & Estreptobacilos Gram - \\
Diplococos Gram - & Gram - & Estafilococos Gram & \\
Estafilococos Gram + & Cocos Gram- & + & \\
& Diplococos Gram + & & \\
\hline
\end{tabular}

${ }^{*} \mathrm{BPE}=($ Balaústre da porta de entrada), $\mathrm{BV}=($ Balaústre vertical $), \mathrm{BH}=($ Balaústre horizontal $), \mathrm{BPS}=$ (Balaústre da porta saída). 
A sobrevivência de microrganismos em superfícies é um importante fator para se avaliar o potencial de exposição a que estão submetidas as pessoas que frequentam um determinado ambiente coletivo, principalmente os que possuem grande fluxo de pessoas, como é o caso dos transportes coletivos (QUEIROZ et al., 2006; MENDONÇA et al., 2008; FERNANDES et al., 2012; GOMES et al., 2012; PINHEIRO e STOPIGLIA, 2015).

Neste estudo, os bacilos Gram-Negativos foram mais prevalentes, com ocorrência em todas as áreas de coleta, apresentando distribuição semelhante nas duas rotas e ocorrendo em toda a extensão do veículo. As bactérias Gram-Negativas são descritas na literatura como os microrganismos mais abundantes no ambiente, e na microbiota humana, com a maioria delas no trato gastrointestinal (MENEZES-SILVA e NEUFELD, 2006). Atualmente, existem 44 gêneros e 176 espécies descritas, como as Enterobacterias, Bacilos Gram-Negativos, amplamente distribuídos na natureza com potencial patogênico para o homem, animais e vegetais (BRASIL, 2013).

0 grupo de Gram-Positivos mais frequente nas duas rotas estudadas, foi o grupo de Estafilococos. O gênero Staphilococcus sp. contém representantes que podem contaminar a pele e membranas das mucosas de pessoas ou objetos inanimados por contato direto ou por aerossol, causando infecções letais por conta dos fatores de virulência ou através de resistência aos antimicrobianos atualmente utilizados (BRASIL, 2013). As bactérias Gram-Positivas também fazem parte da microbiota humana, porém, podem se tornar patogênicas mediante as condições de saúde do indivíduo, pois são microrganismos oportunistas. Em indivíduos sadios pode ocorrer a colonização intermitentemente por cocos desde a amamentação, podendo abrigar esses microrganismos na nasofaringe, ocasionalmente na pele e raramente na vagina (RODRIGUES et al., 2006).

0 isolamento e identificação de microrganismos em balaústres de ônibus de transporte coletivo já foi realizado em outras cidades do Brasil (PINHEIRO e STOPIGLIA, 2015; CORDEIRO et al., 2017; SOUZA et al., 2020). 0 estudo de Rodrigues et al. (2006) foi pioneiro na avaliação microbiológica em transportes coletivos. Os autores avaliaram duas rotas de ônibus, uma hospitalar e uma não hospitalar na Cidade de Curitiba, no Paraná e conseguiram isolar 14 tipos de microrganismos em cinco amostras, dos quais, 85,71\% eram bactérias Gram-Negativas e 12,29\% Gram-Positivas.

Fernandes et al. (2012), avaliaram microrganismos em ônibus do transporte coletivo da cidade de Grande Vitoria-ES. Das 40 amostras analisadas, obtiveram 36 colônias bacterianas, composta por $85 \%$ de bactérias Gram-Positivas e 15\% de GramNegativas. Em outro estudo, Pinheiro e Stopiglia (2015) identificaram bactérias GramPositivas $(77,1 \%)$ e Gram-Negativas $(22,9 \%)$ no transporte público universitário da cidade de Uruguaiana-RS. Já no norte do país, na cidade de Macapá- AP. Souza et al., 2020 encontraram em amostras obtidas de ônibus e micro-ônibus, a espécie Staphylococcus aureus (85\%) e Staphylococcus epidermidis em menor ocorrência, com $15 \%$, além de bacilos Gram-Negativos não fermentadores (20\%) e uma enterobactéria (5\%) de importância médica. 


\section{CONCLUSÃO}

O isolamento e identificação de bactérias em balaústres de ônibus do transporte coletivo de Manaus, confirma a importância da adoção de boas práticas de higienização diariamente nesses transportes e, principalmente, a higiene pessoal da população, como a lavagem das maõs após o uso desse serviço, visando minimizar a contaminação, infecções cruzadas e a alta taxa de morbidade de doenças causadas por bactérias patogênicas.

\section{REFERÊNCIAS}

ARUMUGAM, M.; RAES, J.; PELLETIER E, LE PASLIER D, YAMADA T, MENDE DR, et al. Enterotypes of the human gut microbiome. Nature. 473 (7346) :174-80. 2011.

BRASIL - Agencia Nacional de Vigilância Sanitária. Descrição de meios de cultura empregada nos exames microbiológicos. 2004.

BRASIL - Agencia Nacional de Vigilância Sanitária - Manual de Microbiologia Clínica para o Controle de Infecção Relacionada a Assistência à Saúde. Módulo 6. Detecção e identificação de bactérias de importância médica. 2013.

BRASIL - Instituto Brasileiro de Geografia e Estatística (IBGE) 2020. Disponível em: https://www.ibge.gov.br/cidades-e-estados/am/manaus.html. Acesso em 25 de março de 2020.

BRIDLE, H. Waterborne pathogens. Detection Methods na Applications. Academic Press: London. 2014.

BUBICZ, M.; SELLITTO, M. Qualidade em serviço de transporte de passageiros: um estudo de caso no sistema urbano de Porto Alegre. Produção OnLine. 9 (4): 1676-1901. 2009.

CORDEIRO, P. M. D..; LEANDRO, L. M. G.; VANDESMET, V. C. S.; SOUSA JÚNIOR, D. L.; MENDES, C. F. C. Análise microbiológica de assentos e alça de teto em transportes coletivos da cidade Juazeiro do Norte, Ceará. 4(12): 69-74. 2017.

FERREIRA, D. M. S.; PEREIRA, L. R. G.; CUNHA, T.; ACCIOLY, A. S.; SANTA HELENA, A. A.; HEINEN, R. C. Análise microbiológica de cédulas circulantes em feira livre do Município de Belford Roxo - RJ. Revista Saúde Física \& Mental- UNIABEU. 1 (1): 11-14. 2012.

FERNANDES, A. A. L.; RANGEL, C. D.; SENA, C. J. C., RANGEL, C. V.; MORES, R. Diversidade de bactérias, fungos e formas resistentes de parasitos em duas rotas de ônibus do transporte coletivo da Grande Vitoria - ES. Revista Sapientia. 11: 39-45. 2012.

GOMES, N. C. P. et al. Análise da contaminação bacteriológica do setor de parada de ônibus municipais do terminal rodoviário de uma cidade do interior do estado de São Paulo. J. Health Sci. Inst. 34(3): 140-143. 2016.

GRUPTA, A. Hospital-acquired infections in the neonatal intensive care unit Klebsiella pneumonia. Journal seminars in perinatology. 26: 340. 2002. 
MAGALHÃES, S. Na Paisagem urbana de Manaus a supremacia do ônibus com carroceria de Madeira (1947 - 1957). Revista dos Transportes Públicos - ANTP - Ano 33. 2011.

MENEZES e SILVA, C. H. P.; NEUFELD, P. M. Bacteriologia e micologia para laboratório clínico. Ed. Única. Rio de Janeiro: Revinter. 2006.

MEYER, R. M. P.; GROSTEIN, M. D. Metrópoles brasileiras: seus desafios urbanos e suas perspectivas. Pós - São Paulo. 20: 44-45. 2016.

MURRAY, P. R. Microbiologia médica. 6. ed. Rio de Janeiro: Elsevier. 2009.

PINHEIRO, T. R.; STOPIGLIA, C. D. O. Potencial infeccioso do transporte coletivo universitário da Cidade de Uruguaiana-RS. Anais do VII Salão Internacional de Ensino, Pesquisa e Extensão - Universidade Federal do Pampa. 7:2. 2015.

PREFEITURA MUNICIPAL DE MANAUS. Plan Mob Manaus. Pág. 28, 29 e 44. Disponível em: http://planmob.manaus.am.gov.br/. Acesso em 02 de fevereiro de 2016 as 13:45.

QIN, J.; LI, R.; RAES, J.; ARUMUGAM, M.; BURGDORF, K. S.; MANICHANH, C. et al. A human gut microbial gene catalogue established by metagenomic sequencing. Nature. 464 (7285): 59-65. 2010.

RODRIGUES, A. P. C.; NISHI, C. Y. M.; GUIMARÃES, A. T. B. Levantamento de bactérias, fungos e formas de resistência de parasitos em duas rotas de ônibus do transporte coletivo de Curitiba- Paraná. RUBS, Curitiba. 2 (2): 24-31. 2006.

ROILIDES, E.; KYRIAKIDES,G.; KADILTSOGLOU, I.; FARMAKI, E.; VENZON, 0.; KATSAVETI,A.; KREMEPAULOS, G. Septicemia due to multiresistant Klebsiella pneumonia in a neonatal unit: a case control study. American journal of perinatology. 17:35. 2000.

SILVA, R. M.; PAULA J. F.; ALMEIDA-MARQUES, R. V. D.; ALMEIDA, L. F. D.; CAVALCANTI Y. W. Análise estrutural e microbiológica de chupetas de crianças de creches públicas e particulares. Revista Cubana de Estatística. Imperatriz-Ma. Brasil. 51(1): 24-34. 2014.

SOUZA. R. A.; PORCY, C.; MENEZES, R. A. O . Análise bacteriológica das barras de apoio dos ônibus utilizados no transporte público da cidade de Macapá-Amapá. REAC/EJSC. 8: e2937. 2020.

YALOWITZ, M.; BROOK, I. The Recovery of Bacterial from the Handpiece of a High School Telephone. J. Environ Health. 65:18-20. 2003.

WILSON, J. A.; LOVEDAY, H. P.; HOFFMAN P. N.; PRATT, R. J. Uniform: an evidence review of the microbiological Significance of uniforms and uniform policy in the Prevention and control of healthcare-associated Infections. Report to the Department of Health (England). J Hosp Infect. 66 (4): 301-307. 2007. 


\section{Capítulo 18}

Bactérias associadas ao intestino do mosquito Aedes aegypti (Diptera: Culicidae): Uma revisão sobre a diversidade e função

Sabrina da Fonseca Meireles

Ricardo de Melo Katak

Miriam Silva Rafael

Resumo: Os insetos albergam muitos micro-organismos que colonizam e crescem dentro de seus tecidos, principalmente no sistema digestivo. Considerando a importância epidemiológica do Aedes aegypti como vetor de arbovírus; as interações diretas hospedeiro-parasitos, mas, principalmente, relacionados à competência vetorial na interação parasito-vetor; e o desenvolvimento de tecnologias de sequenciamento de alto rendimento, propôs-se a realização de um levantamento na literatura científica sobre a diversidade de comunidades bacterianas associadas ao intestino do mosquito Ae. aegypti. Fornecemos por meio da análise de 20 artigos completos, uma visão geral do conhecimento atual disponível na literatura científica sobre a composição, função e sinergismo de bactérias intestinais associadas ao Ae. aegypti.

Palavras-chave: Arbovírus, Dengue, Inseto, Microbiota, Simbiose. 


\section{INTRODUÇÃO}

Aedes (Stegomyia) aegypti (Linnaeus, 1762) é um mosquito altamente antropofílico e de grande importância epidemiológica nos trópicos e subtrópicos, devido a sua capacidade vetorial em grande parte do mundo para a transmissão de doenças arbovirais como Dengue, Zika e Chikungunya (KRAEMER et al., 2015; SOUZA-NETO et al., 2019).

Nas últimas décadas, os inseticidas químicos, temefós e deltametrina, têm sido usados em programas para o controle de mosquitos. No entanto, há relatos de resistência nesses insetos, que pode estar relacionada a uma redução na taxa de penetração do inseticida ou em seu metabolismo pelo inseto (VALLE et al., 2019).

Esses mosquitos albergam diversas comunidades bacterianas, incluindo principalmente os filos Actinobacteria, Bacteroidetes e Proteobacteria (MINARD et al., 2013; MANCINI et al., 2018). A manipulação dessa microbiota é um campo promissor para desenvolver novas estratégias de controle de vetores, como alterá-las geneticamente para expressar efetores anti-patógenos ou interromper sua simbiose natural com o inseto hospedeiro (RAMIREZ et al., 2014).

A função de proteção contra patógenos vem sendo cada vez mais estudada por ser um fator diretamente relacionado à competência vetorial de alguns insetos (HEDGE et al., 2015). Os casos de Enterobacter sp. (Esp_Z) em Anopheles gambie e de Chromobacterium $\left(C s p_{-} P\right.$ ) em Ae. aegypti, apresentaram redução significativa na suscetibilidade às infecções de Plasmodium falciparum e DEN-V, respectivamente (CIRIMOTICH et al., 2011; RAMIREZ et al., 2014). Nessa perspectiva, fornecemos uma revisão do conhecimento atual disponível na literatura científica sobre a composição bacteriana do intestino de mosquitos Ae. aegypti, para auxiliar na compreensão da diversidade e das relações simbióticas nesse mosquito.

\section{REFERENCIAL TEÓRICO}

\subsection{ASPECTOS BIOLÓGICOS DO Aedes aegypti}

O Ae. aegypti apresenta morfologicamente, na forma adulta, escamas na cor escura, faixas brancas nas bases dos segmentos tarsais e um desenho em forma de lira no mesonoto (figura 1). 0 macho se diferencia da fêmea por possuir antenas plumosas e palpos mais longos (FORATTINI, 2002).

Figura 4. Fêmea do mosquito Aedes aegypti.

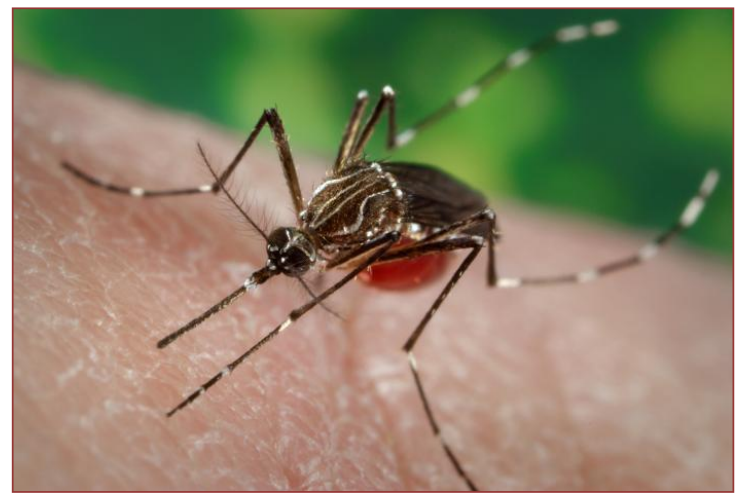

CDC (2020). 
O ciclo de vida desse mosquito é holometábolo completo e compreende as fases: ovo, larva, pupa e adulto (figura 2). Em geral, a maioria dos mosquitos depende da ingestão de carboidratos, usualmente provenientes de seivas, flores e frutos. 0 sangue de vertebrado é uma fonte rica e única de proteínas para processos anabólicos do mosquito, como a vitelogênese e produção de ovos. Somente as fêmeas dos mosquitos são hematófagas e o sangue ingerido é armazenado no intestino médio posterior, onde as proteínas são digeridas em aminoácidos (CONSOLI e LOURENÇO-DE-OLIVEIRA, 1994).

Figura 5. Representação esquemática do ciclo de vida do Aedes aegypti.

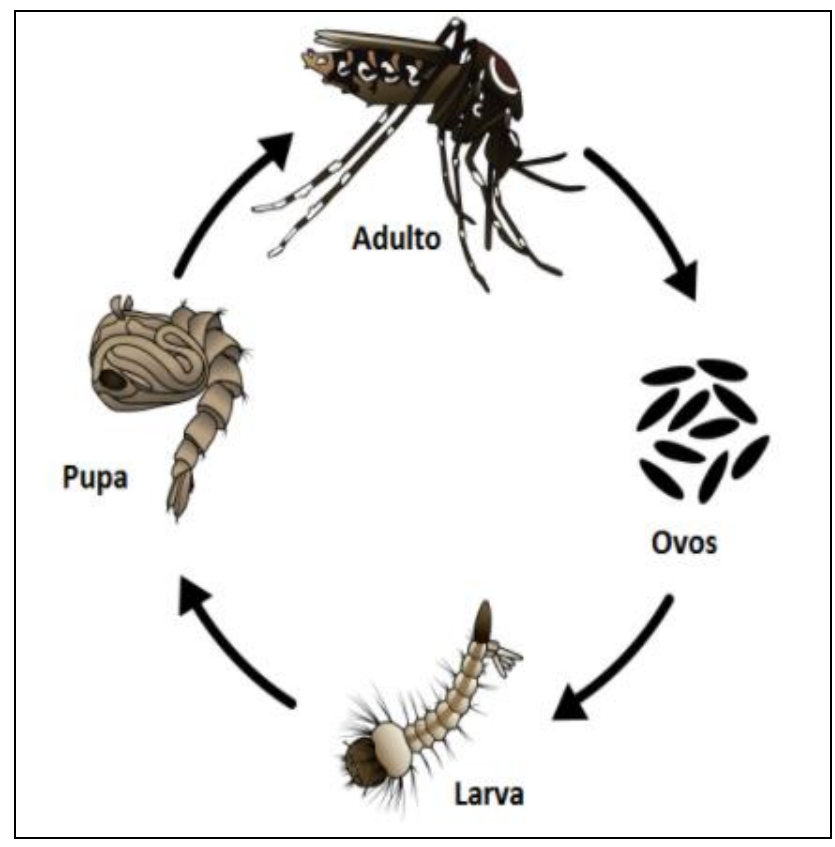

Fonte: IOC/Fiocruz e CDC (2019), adaptado.

\subsection{MICROBIOTA ASSOCIADA AO MOSQUITO}

\subsubsection{BACTERIANA}

Os insetos contêm muitos micro-organismos que colonizam e crescem dentro de seus tecidos, principalmente no sistema digestivo. Alguns taxa bacterianos são transmitidos transtadialmente (permanecendo com o hospedeiro de um estágio de vida para o próximo) de larvas através de pupas para adultos (COON et al., 2014; DUGUMA et al., 2015), fornecendo um subconjunto inicial de micróbios que podem influenciar as interações micróbio-hospedeiro.

0 microambiente intestinal dos mosquitos é composto por três estruturas, denominadas: intestino anterior/estomodeu, médio/mesêntero e posterior/proctodeu, que servem de receptores, para o primeiro contato com o alimento, parasitas, bactérias nocivas, vírus e toxinas do ambiente (figura 3) (YADAV et al., 2018). 
Figura 6. Esquema da anatomia interna dos mosquitos.

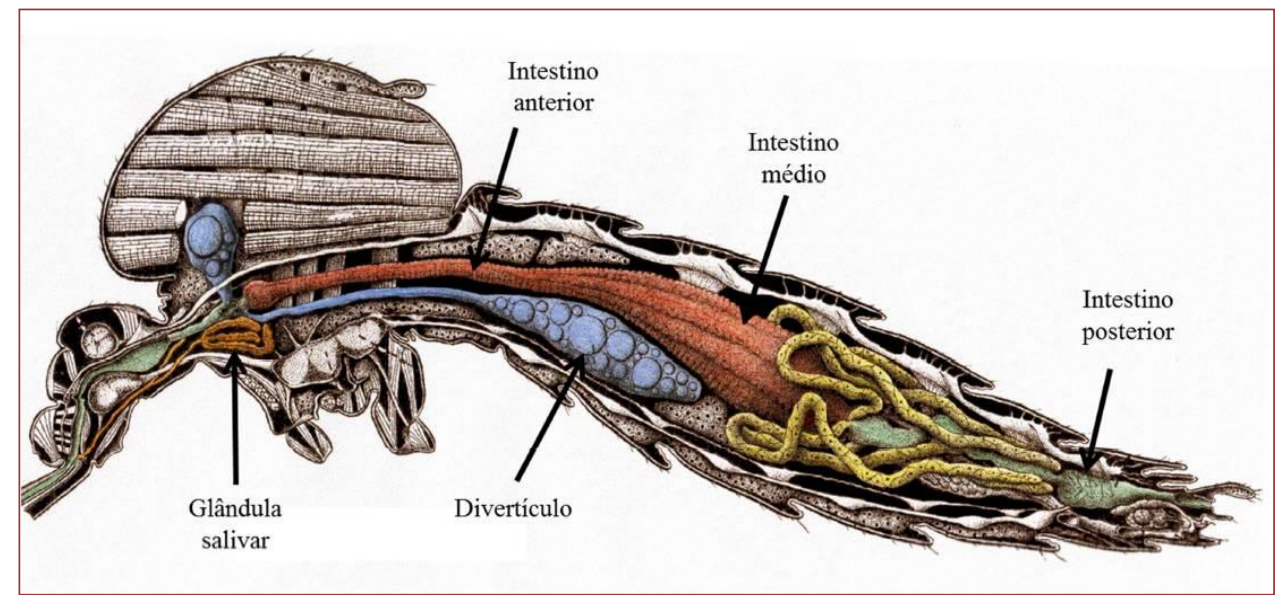

Fonte: modificado de Jobling (1987).

Os filos Actinobacteria, Bacteroidetes e Proteobacteria podem desempenhar funções metabólicas e fisiológicas importantes para o inseto, como nutrição, desenvolvimento, comportamento, homeostase, síntese de carboidratos e proteínas, reprodução e modulação do sistema imunológico (GAIO et al., 2011).

As principais estruturas colonizadas por bactérias são o lúmen do intestino médio e o ambiente intracelular (DOUGLAS, 2011). Além destas, estruturas anexas como, divertículo (GUSMÃO et al., 2007), glândulas salivares (SHARMA et al., 2014), túbulos de Malpighi (CHAVSHIN et al., 2014) e ovários (GUSMÃO et al., 2010; ALVARADO et al., 2021) também abrigam micro-organismos.

As larvas recém eclodidas são estéreis e adquirem uma microbiota intestinal a cada troca de muda (MINARD et al., 2013; STRAND, 2017). As comunidades bacterianas majoritárias descritas ao longo do desenvolvimento larval e em adultos, são bactérias gram-negativas aeróbias e anaeróbias facultativas (WANG et al., 2011; BOISSIÈRE et al., 2012; COON et al., 2014; DUGUMA et al., 2015; MUTURE et al., 2016; DADA et al., 2018) e podem ser transmitidas transtadialmente para os adultos (COON et al., 2014; DUGUMA et al., 2015).

A recente exploração em larga escala da biodiversidade de micro-organismos simbióticos tem sido possível devido ao desenvolvimento do sequenciamento de próxima geração (NGS). Essa tecnologia renovou o interesse de usar micro-organismos como ferramentas para controlar populações de mosquitos vetores de parasitas e vírus (BOISSIÈRE et al., 2012; MINARD et al., 2013). Em contraste com as técnicas convencionais mediadas por cultura, NGS apresenta a vantagem de identificar todo o conteúdo bacteriano em uma amostra biológica (METZKER, 2010).

\subsection{ASPECTOS EPIDEMIOLÓGICOS}

O Ae. aegypti é um mosquito de grande importância na saúde pública, devido a sua capacidade vetorial em grande parte do mundo para a transmissão dos quatro sorotipos do vírus dengue (DENV-1, 2, 3 e 4), chikungunya (CHIKV), febre amarela (YFV), e zika (ZIKV) (KRAEMER et al., 2015; SOUZA-NETO et al., 2019).

A dengue é a virose transmitida por mosquitos, que mais infecta os humanos. De acordo com o Ministério da Saúde, em 2020, até 12 de dezembro foram registrados 
979.764 casos prováveis de dengue no Brasil. Além de chikungunya e zika, com 80.914 e 7.119 casos, respectivamente (BRASIL/Ms2020).

0 controle vetorial de mosquitos de importância médica é realizado em diversas partes do mundo, através de inseticidas químicos sintéticos das classes dos temefós, organofosforados e piretróides e/ou por meio de fitoinseticidas e micro-organismos, especialmente as bactérias Bacillus thuringiensis israelenses (Bti) e Wolbachia, considerados os agentes biológicos mais específicos no controle de mosquitos, uma vez que não representam riscos para os seres humanos (AHMAD et al., 2021; VIANA et al., 2021).

Outra abordagem é o uso da paratrangênese - técnica capaz de eliminar um patógeno das populações vetoras através da transgenia de um simbionte do vetor, onde micro-organismos associados ao intestino de vetores são estimulados para secretar moléculas anti-patogênicas, matando os patógenos. Sabendo disso, tem-se aumentado os estudos sobre a microbiota associada aos insetos, pois: 1) a colonização do intestino com comensal ou comunidades microbianas mutualísticas pode aumentar a resistência do hospedeiro contra a invasão de parasitas; 2) para insetos vetores de doenças, microorganismos simbiontes podem influenciar na competência vetorial ou no tempo de desenvolvimento e, assim, 3) fornece alvos para o controle da doença em potencial (MANCINI et al., 2016; WANG e JACOBS-LORENA, 2013).

\section{MATERIAL E MÉTODOS}

Esta revisão foi baseada na literatura especializada, selecionada por meio de buscas nas bases de dados científicos utilizadas no âmbito institucional, como: Scientific Eletronic Library Online - SCIELO (www.scielo.org), SCOPUS (www.scopus.com), SCIENCE DIRECT (www.sciencedirect.com) e SPRINGER (link.springer.com). A última pesquisa foi realizada em março de 2021, utilizando os descritores: Bactérias associadas ao intestino de Aedes aegypti; Microbiota intestinal de Aedes e, Comunidades bacterianas do intestino de Aedes.

A estratégia de seleção dos artigos seguiu as seguintes etapas: 1- identificação, 2 triagem, 3 - elegibilidade e 4 - inclusão. Foram incluídos somente estudos completos, com resultados específicos de identificação e / ou diversidade bacteriana associada ao intestino de Ae aegypti, publicados no período compreendido entre 2010 e 2020 . As metodologias dependentes e independentes de cultivo bacteriano foram consideradas, e nenhuma restrição de idioma foi aplicada.

\section{RESULTADOS E DISCUSSÃO}

Foram identificados 130 estudos nas bases de dados. Destes, 71 artigos foram excluídos, pois eram textos incompletos e fora do período proposto. Dessa forma, 59 artigos foram selecionados para leitura criteriosa, sendo excluídos 39 pelos critérios de inclusão. Assim, somente 20 artigos completos foram considerados para a construção da revisão bibliográfica acerca do tema. Os trabalhos revisados estão amostrados na tabela 1, com foco nos taxa descritos e no método de exploração da biodiversidade utilizado. 
Tabela 1. Descrição da microbiota intestinal de Aedes aegypti, contendo: metodologia (dependente ou independente de cultivo), resultados das pesquisas e dados de autoria (autor e ano).

\begin{tabular}{|c|c|c|c|}
\hline \multicolumn{2}{|r|}{ Metodologia } & Bactérias & Referência \\
\hline 1 & Independente & $\begin{array}{l}\text { Gêneros: Actinotignum, Aeromonas, Leucobacter, } \\
\text { Sphingobacterium, Pseudomonas, } \\
\text { Stenotrophomonas, Rahnella, Serratia }\end{array}$ & MUTURI et al., 2021 \\
\hline 2 & Independente & $\begin{array}{l}\text { Filos: Actinobacteria, Bacteroidetes e } \\
\text { Proteobacteria }\end{array}$ & $\begin{array}{l}\text { MÖHLMANN et al., } \\
2020\end{array}$ \\
\hline 3 & Independente & $\begin{array}{l}\text { Filos: Actinobacteria, Bacteroidetes, } \\
\text { Cyanobacteria, Firmicutes e Proteobacteria }\end{array}$ & ONYANGO et al., 2020 \\
\hline 4 & Independente & $\begin{array}{l}\text { Filos: Actinobacteria, Bacterioidetes, } \\
\text { Deferribacteres, Firmicutes, Gemmatimonadetes, } \\
\text { Proteobacteria, Tenericutes, Verrucomicrobia e } \\
\text { WS6 }\end{array}$ & $\begin{array}{l}\text { ARÉVALO-CORTÉS et } \\
\text { al., } 2020\end{array}$ \\
\hline 5 & Dependente & $\begin{array}{l}\text { Gêneros: Escherichia, Pseudomonas, Serratia e } \\
\text { Stenotrophomonas }\end{array}$ & $\begin{array}{l}\text { MOLINA-HENAO et } \\
\text { al., } 2019 .\end{array}$ \\
\hline 6 & Independente & $\begin{array}{l}\text { Filos: Actinobacteria, Bacteroidetes, } \\
\text { Proteobacteria (Gammaproteobacteria, } \\
\text { Betaproteobacteria e Alphaproteobacteria) e } \\
\text { Firmicutes }\end{array}$ & MUTURI et al., 2019 \\
\hline 7 & Independente & $\begin{array}{l}\text { Actinobacteria, Firmicutes, Flavobacteria e } \\
\text { Proteobacteria. }\end{array}$ & $\begin{array}{l}\text { COATSWORTH et al., } \\
2018 .\end{array}$ \\
\hline 8 & Independente & $\begin{array}{l}\text { Gênero: Aeromonas, Enterobacter, Flavobacterium, } \\
\text { Intestinibacter, Luteibacter, Marinomonas, } \\
\text { Methylobacterium, Microbacterium, Pseudomonas, } \\
\text { Pseudoalteromonas, Rhodanobacter e } \\
\text { Stenotrophomonas }\end{array}$ & DICKSON et al., 2018 \\
\hline 9 & Independente & $\begin{array}{l}\text { Filos: Actinobacteria, Bacteroidetes, Firmicutes e } \\
\text { Proteobacteria }\end{array}$ & MANCINI et al., 2018 \\
\hline 10 & Independente & Gammaproteobacteria e Firmicutes & CHARAN et al., 2016. \\
\hline 11 & $\begin{array}{l}\text { Dependente e } \\
\text { Independente }\end{array}$ & $\begin{array}{l}\text { Gêneros: Acinetobacter, Aeromonas Pseudomonas } \\
\text { e Stenotrophomonas } \\
\text { Família: Comamonadaceae, Enterobacteriaceae e } \\
\text { Oxalobacteraceae }\end{array}$ & DAVID et al., 2016 \\
\hline 12 & Dependente & Filos: Proteobacteria, Firmicutes e Actinobacteria & YADAV et al., 2015 \\
\hline 13 & Independente & $\begin{array}{l}\text { Filos: Bacteriodetes, Gammaproteobacteria e } \\
\text { Betaproteobacteria }\end{array}$ & CHARAN et al., 2013. \\
\hline 14 & Dependente & $\begin{array}{l}\text { Gêneros: Bacillus, Elizabethkingia, } \\
\text { Enterococcus, Klebsiella, Pantoea, Serratia e } \\
\text { Sphingomonas }\end{array}$ & TERENIUS et al., 2012 \\
\hline 15 & Dependente & Serratia odorifera & $\begin{array}{l}\text { APTE-DESHPANDE et } \\
\text { al., } 2011\end{array}$ \\
\hline 16 & Dependente & Enterobacter asburiae & OLIVEIRA et al. 2011 \\
\hline 17 & & Gêneros: Enterobacter sp., Serratia sp. & GAIO et al., 2011. \\
\hline 18 & Dependente & $\begin{array}{l}\text { Classes: Alphaproteobacteria, Bacilli, } \\
\text { Betaproteobacteria e Gammaproteobacteria }\end{array}$ & RAMIREZ et al., 2012 \\
\hline 19 & Independente & $\begin{array}{l}\text { Classe: Alphaproteobacteria, Flavobacteria e } \\
\text { Gammaproteobacteria. }\end{array}$ & $\begin{array}{l}\text { OSEI-POKU et al., } \\
2012\end{array}$ \\
\hline 20 & $\begin{array}{l}\text { Dependente e } \\
\text { Independente }\end{array}$ & $\begin{array}{l}\text { Gêneros: Asaia, Bacillus, Enterococcus, } \\
\text { Klebsiella, Kluyvera, Pantoea e Serratia }\end{array}$ & GUSMÃO et al., 2010 \\
\hline
\end{tabular}

Em geral, o intestino dos mosquitos abriga uma ampla variedade de microorganismos, como fungos (FRANKEL-BRICKER, 2020) e bactérias, principalmente 
(COON et al., 2014; DADA et al., 2018). Na tabela 1, observa-se a diversidade de filos de comunidades bacterianas associadas ao intestino de Ae. aegypti e, certa similaridade dos grupos é observada nos achados de YADAV et al. 2015, que catalogou por métodos dependentes de cultivo, bactérias pertencentes aos filos Actinobacteria, Bacteroidetes e Proteobacteria, assim como MÖHLMANN et al. 2020, utilizando métodos independentes de cultivo.

A colonização do intestino via ambiente / habitat nas primeiras fases de desenvolvimento larval é imprescindível, pois em condições assépticas não sobrevivem (COON et al., 2014; AKORLI et al., 2019). Bactérias simbiontes do gênero Asaia, por exemplo, influenciam no tempo de desenvolvimento larval de Anopheles gambiae (MITRAKA et al., 2013) e Escherichia, levam à hipóxia no intestino de Ae. aegypti, interpretada como um sinal para o crescimento e indução de muda pelo hormônio ecdisona (VALZANIA et al., 2018). Não obstante, a adição de bactérias inativadas no ambiente de desenvolvimento larval não produz o mesmo efeito, confirmando-se a necessidade de microrganismos nos criadouros (MITRAKA et al., 2013).

A função das bactérias intestinais, ainda são em boa parte, desconhecidas. Gaio et al. (2011) após verificarem a contribuição de bactérias do intestino médio de Ae. aegypti na digestão de sangue e na produção de ovos, observaram em fêmeas tratadas com antibióticos que a redução de bactérias afetava a lise das hemácias, retardava a digestão das proteínas do sangue e reduzia a produção de ovos. Os autores inferiram que o Ae. aegypti e suas bactérias do intestino médio trabalham em sinergia para digestão do sangue. Em outros gêneros, como o Anopheles, a bactéria Serratia marcescens reduz a carga parasitária de Plasmodium e quando tratados com antibióticos apresentam maior suscetibilidade à infecção por P. berghei (KALAPPA et al., 2018).

Os mosquitos vetores de doenças podem se alimentar de sangue em vários hospedeiros vertebrados dentro do mesmo ciclo gonotrófico e a fonte de alimentação de sangue pode ter um forte impacto sobre a microbiota do vetor (GONZALEZ et al., 2015). Muturi et al. (2021) observaram que a alimentação mista de sangue é determinante na composição da comunidade bacteriana do intestino em mosquitos. Em outro estudo, Muturi et al., (2018) detectaram 284 unidades taxonômicas operacionais bacterianas (OTUs), pertencentes a 14 filos em nove espécies de mosquitos, como Actinobacteria, Firmicutes e Proteobacteria, representando 95\% do total de sequências. De acordo com os autores a diversidade microbiana é influenciada pelo local de coleta do mosquito, sugerindo que a localização do hospedeiro desempenha um papel importante na formação da própria microbiota.

Diante da importância das comunidades bacterianas intestinais do mosquito Ae. aegypti, vale salientar os fatores que determinam a composição dessa microbiota em mosquitos, como: (1) características fisiológicas ou bioquímicas do intestino - $\mathrm{pH}$, potencial redox e enzimas digestivas (DILLON e DILLON, 2004); (2) sistema imunológico - vias de sinalização: Toll, Immune Deficiency (IMD) e Janus Kinase/Signal Transducer and Activator of Transcription (JAK-STAT) (LEMAITRE e HOFFMAN, 2007); (3) infecção por arbovírus - Chikungunya (CHIKV), vírus do Oeste do Nilo (WNV) (ZOUACHE et al., 2012; ZINK et al., 2015); (4) estágio de vida - ovo, larva, pupa, adulto (KIM et al., 2015); (5) sexo - macho/fêmea (ZOUACHE et al., 2011); (6) dieta - micro-organismos, matéria orgânica, sangue/néctar (GUSMÃO et al., 2010; WANG et al., 2011) e; (7) hábitat aquático/terrestre (MINARD et al., 2013). Considerando estas variáveis, pesquisas têm sido realizadas, tendo como alvo a microbiota intestinal, para compreender a relação parasito-vetor. 
Até o momento, estudos independentes mostram que os intestinos de mosquitos do gênero Aedes, Anopheles e Culex apresentam um conjunto consistente de bactérias dos gêneros Acinetobacter, Aeromonas, Alcaligenes, Asaia, Bacillus, Brevibacterium, Brevibacillus, Citrobacter, Chryseobacterium, Corynebacterium, Delftia, Enterobacter, Enterococcus, Ehrlichia, Elizabethkingia, Escherichia, Exiguobacterium, Flavobacterium, Janibacter, Klebsiella, Kocuria, Leucobacter, Lisinibacillus, Microbacterium, Micrococcus, Neisseria, Nocardia, Paenibacillus, Pantoea, Providencia, Pseudomonas, Serratia, Shewanella, Shigella, Sphingomonas, Staphylococcus, Stenotrophomonas, Thorsellia, Xanthomonas e Wolbachia, as quais estão sendo melhor investigadas quanto aos seus efeitos na fisiologia, transmissão vertical/horizontal à prole, longevidade, fertilidade, e desintoxicação de agentes xenobióticos (GUSMÃO et al., 2010; ZOUACHE et al., 2011; TERENIUS et al., 2012; COON et al., 2014; MINARD et al., 2015; DADA et al., 2018; MUTURI et al., 2018, 2021).

Dentre os gêneros supracitados, o simbionte intracelular mais prevalente é do gênero Wolbachia, transmitido verticalmente e presente em cerca de $60 \%$ dos insetos (OLIVEIRA et al., 2015). A descoberta de que cepas específicas de Wolbachia são capazes de reduzir a sobrevivência dos mosquitos (MIN e BENZER, 1997) e bloquear infecções por vírus de RNA em drosófilas (HEDGES et al., 2008), estimulou o emprego desta bactéria em estratégias de controle de arboviroses, como a dengue (MCGRAW e O'NEILL, 2013).

Em resumo, a literatura mostra que a microbiota associada aos mosquitos está restrita aos gêneros de importância médica: Aedes, Anopheles e Culex, com a finalidade de identificar seu papel no comportamento desses mosquitos, biologia e transmissão de patógenos (MINARD et al., 2013; YADAV et al., 2015; DADA et al., 2018). As técnicas utilizadas para acessar essa diversidade microbiana, são baseadas em métodos dependentes ou independentes de cultivo. No entanto, em termos de cultivo bacteriano, ainda é difícil prover todas as condições apropriadas para o crescimento de microorganismos.

\section{CONCLUSÃO}

Esta revisão apresenta os principais dados sobre a composição e função de bactérias intestinais associadas ao Ae aegypti. A literatura dispõe de dados que abrem caminhos de pesquisa para entender melhor as interações entre comunidades microbianas e coinfecção de patógenos, e ainda, para decifrar a interação entre as bactérias e os traços da história de vida do mosquito. Portanto, conhecer as funções dessas comunidades microbianas simbiontes é importante para compreender suas relações e dinâmica entre microrganismos-hospedeiro.

\section{AGRADECIMENTOS}

Agradecemos à Coordenação de Apoio à Formação de Pessoal de Nível Superior (CAPES), Conselho Nacional de Desenvolvimento Científico e Tecnológico (CNPq) pela bolsa de fomento, ao Projeto número 465540 / 2014-7 (CNPq), Coordenador Dr. Adalberto Luis Val e FAPEAM / SEPLANCTI / Governo do Estado do Amazonas, POSGRAD, projeto número 002/2016. 


\section{REFERÊNCIAS}

AHMAD NA, MANCINI M-V, ANT TH, MARTINEZ J, KAMARUL GMR, NAZNI WA, HOFFMANN AA, SINKINS SP. Wolbachia strain wAlbB maintains high density and dengue inhibition following introduction into a field population of Aedes aegypti. Phil. Trans. R. Soc. B 376: 20190809. 2021.

AKORLI, J.; NAMAALI, P. A.; AMETSI, G. W.; EGYIRIFA, R. K.; PEL, N. A. P. Generational conservation of composition and diversity of field-acquired midgut microbiota in Anopheles gambiae (sensu lato) during colonization in the laboratory. Parasit Vectors. 12: 27. 2019.

ALVARADO, W. A.; AGUDELO, S. O.; VELEZ, I. D.; VIVERO, R. J. Description of the ovarian microbiota of Aedes aegypti (L) Rockefeller strain. Acta Tropica. 214: 105765. 2021.

APTE-DESHPANDE, A.; PAINGANKAR, M.; GOKHALE, M. D.; DEOBAGKAR, D. N. Serratia odorifera a midgut inhabitant of Aedes aegypti mosquito enhances its susceptibility to dengue-2 virus. PLoS ONE. 7: e40401. 2012.

ARÉVALO-CORTÉS, A.; MEJIA-JARAMILLO, A. M.; GRANADA, Y.; COATSWORTH, H.; LOWENBERGER, C.; TRIANA-CHAVEZ, O. The Midgut Microbiota of Colombian Aedes aegypti Populations with Di erent Levels of Resistance to the Insecticide Lambda-cyhalothrin. Insects. 11: 584. 2020.

BOISSIÈRE, A.; TCHIOFFO, M. T.; BACHAR, D.; ABATE, L.; MARIE, A.; NSANGO, S. E.; SHAHBAZKIA, H. R.; AWONO-AMBENE, P. H.; LEVASHINA, E. A.; CHRISTEN, R.; et al. Midgut microbiota of the malaria mosquito vector Anopheles gambiae and interactions with Plasmodium falciparum infection. PLoS Pathog. 8:e1002742. 2012.

BRASIL. Boletim Epidemiológico, Secretaria de Vigilância em Saúde, Ministério da Saúde. 13 Volume 51 | № 51 | Dez. 2020. Acessado em 21/03/2021. file://C:/Users/Sabrina/Documents/Publica\%C3\%A7\%C3\%B5es/E-

Book\%20multidisciplinar/boletim_epidemiologico_svs_51-2020.pdf

CIRIMOTICH, C. M.; DONG, Y.; CLAYTON, A. M.; SANDIFORD, S. L.; SOUZA-NETO, J. A.; MULENGA, M.; DIMOPOULOS, G. Natural microbe-mediated refractoriness to Plasmodium infection in Anopheles gambiae. Science. 332: 855-858. 2011.

COATSWORTH, H.; CAICEDO, P. A.; VAN ROSSUM, T.; OCAMPO, C. B.; LOWENBERGER, C. The Composition of Midgut Bacteria in Aedes aegypti (Diptera: Culicidae) That Are Naturally Susceptible or Refractory to Dengue Viruses. J. Insect Sci. 18. 2018.

COON, K. L.; VOGEL, K. J.; BROWN, M. R.; STRAND, M. R. Mosquitoes rely on their gut microbiota for development. Mol Ecol. 23: 2727-2739. 2014.

CONSOLI, R. A. G. B.; LOURENÇO-DE-OLIVEIRA, R. Principais Mosquitos de Importância Sanitária no Brasil. Rio de Janeiro - Fiocruz. 228p. 1994.

CHARAN, S. S.; PAWAR, K. D.; SEVERSON, D. W.; PATOLE, M. S.; SHOUCHE, Y. S. Comparative analysis of midgut bacterial communities of Aedes aegypti mosquito strains varying in vector competence to dengue virus. J Parasitol Res. 112: 2627-2637. 2013. 
CHARAN, S. S.; PAWAR, K. D.; GAVHALE, S. D.; TIKHE, C. V.; CHARAN, N. S.; ANGEL, B.; JOSHI, V.; PATOLE, M. S.; SHOUCHE, Y. S. Comparative analysis of midgut bacterial communities in three aedine mosquito species from dengue-endemic and non-endemic areas of Rajasthan, India. Med Vet Entomol. 30 (3): 264-77. 2016.

CHAVSHIN, A. R. et al. Isolation and identification of culturable bacteria from wild Anopheles culicifacies, a first step in a paratransgenesis approach. Parasites \& Vectors. 7: 419. 2014.

DADA, N.; SHETH, M.; LIEBMAN, K.; PINTO, J.; LENHART, A. Whole metagenome sequencing reveals links between mosquito microbiota and insecticide resistance in malaria vectors. SCiEntifiC RePortS. 8:2084. 2018.

DAVID, M. R.; DOS SANTOS, L. M. B.; VICENTE, A. C. P.; MACIEL-DE-FREITAS, R. Effects of environment, dietary regime and ageing on the dengue vector microbiota: evidence of a core microbiota throughout Aedes aegypti lifespan. Mem. Inst. Oswaldo Cruz. 111: 9. 2016.

DICKSON, L. B.; GHOZLANE, A.; VOLANT, S.; BOUCHIER, C.; MA, L.; VEGA-RÚA, A.; DUSFOUR, I.; JIOLLE, D.; PAUPY, C.; MAYANJA, M.; et al. Diverse laboratory colonies of Aedes aegypti harbor the same adult midgut bacterial microbiome. Parasit. Vectors.11: 207. 2018.

DILLON, R. J.; DILLON, V. M. The gut bacteria of insects: nonpathogenic interactions. Annu Rev Entomol. 49:71-92. 2004.

DUGUMA, D.; HALL, M. W.; RUGMAN-JONES, P.; STOUTHAMER, R.; TERENIUS, O.; NEUFELD, J. D. WALTON, W. Developmental succession of the microbiome of Culex mosquitoes. BMC Microbiol. 15:140. 2015.

FORATTINI, O. P. Culicidologia médica. São Paulo: EDUSP.v2. 2002.

FRANKEL-BRICKER, J. Shifts in the microbiota associated with male mosquitoes (Aedes aegypti) exposed to an obligate gut fungal symbiont (Zancudomyces culisetae). Scientific Reports.10: 12886. 2020.

GAIO, A. O.; GUSMÃO, D. S.; SANTOS, A.V.; BERBERT-MOLINA, M. A.; PIMENTA, P. F.; LEMOS, F. Contribution of midgut bacteria to blood digestion and egg production in Aedes aegypti (diptera: culicidae) (L.). Parasit Vectors. 4: 105. 2011.

GONZALEZ E, GALLEGO M, MOLINA R, ABRAS A, ALCOVER MM, BALLART C, et al. Identification of blood meals in field captured sand flies by a PCR-RFLP approach based on cytochrome b gene. Acta Trop. 152:96-102. 2015.

GUSMÃO, D. S.; SANTOS, A. V.; MARINI, D. C.; RUSSO, E. S.; PEIXOTO, A. M.; BACCI, JÚNIOR, M. First isolation of microorganisms from the gut diverticulum of Aedes aegypti (Diptera: Culicidae): new perspectives for an insect-bacteria association. Mem Inst Oswaldo Cruz. 102(8): 919-24. 2007.

GUSMÃO, D.S.; SANTOS, A. V.; MARINI, D. C.; BACCI, M. JR.; BERBERT-MOLINA, M. A.; LEMOS, F. J. Culture-dependent and culture-independent characterization of 
microorganisms associated with Aedes aegypti (Diptera: Culicidae) (L.) and dynamics of bacterial colonization in the midgut. Acta Trop. 115: 275-281. 2010.

HEDGES, L. M, BROWNLIE J. C.; O'NEILL, S. L.; JOHNSON, K. N. Wolbachia and virus protection in insects. Science. 322 (5902): 702.2008.

JOBLING, B. Anatomical drawing of biting flies. London: British Museum (Natural History) and the Wellcome Trust Publisher. 119p. 1987.

KALAPPA, D. M.; SUBRAMANI, P. A.; BASAVANNA, S. K.; GHOSH, S. K.; SUNDARAMURTHY, V.; URAGAYALA, S.; TIWARI, S.; ANVIKAR, A. R.; VALECHA, N. Influence of midgut microbiota in Anopheles stephensi on Plasmodium berghei infections. Malar J. 25; 17 (1): 385. 2018.

KIM, C. H.; LAMPMAN, L. R.; MUTURI, E. J. Bacterial communities and midgut microbiota associated with mosquito populations from waste tires in East-Central Illinois. J Med Entomol. 52(1): 63-75. 2015.

KRAEMER, M. U.; SINKA, M. E.; DUDA, K. A.; MYLNE, A. Q.; SHEARER, F. M.; BARKER, C. M.; MOORE, C. G.; CARVALHO, R. G.; COELHO, G. E.; BORTEL, W. V.; HENDRICKX, G.; SCHAFFNER, F.; ELYAZAR, I. R. F.; TENG, H. J.; BRADY, O. J.; MESSINA, J. P.; PIGOTT, D. M.; SCOTT, T. W.; SMITH, D. L.; WINT, G. R. W.; GOLDING, N.; HAY, S. I. The global distribution of the arbovirus vectors Aedes aegypti and Aedes albopictus. eLife. 4: e08347. 2015.

LEMAITRE, B.; HOFFMANN, J. The host defense of Drosophila melanogaster. Annu Rev Immunol. 25: 697-743. 2007.

MANCINI, M. V.; SPACCAPELO R.; DAMIANI, C.; ACCOTI, A.; TALLARITA, M.; PETRAGLIA, E.; ROSSI, P.; CAPPELLI, A.; CAPONE, A.; PERUZZI, G.; VALZANO, M.; PICCIOLINI, M.; DIABATÉ, A.; FACCHINELLI, L.; RICCI, I.; FAVIA, G. Paratransgenesis to control malaria vectors: A semi-field pilot study. Parasit Vectors. 9: 140. 2016.

MANCINI, M. V.; DAMIANI, C.; ACCOTI, A.; TALLARITA, M.; NUNZI, E.; CAPPELLI, A.; BOZIC, J.; CATANZANI, R.; ROSSI, P.; VALZANO, M.; SERRAO, A.; RICCI.; SPACCAPELO, R.; FAVIA, G. Estimating bacteria diversity in different organs of nine species of mosquito by next generation sequencing. BMC Microbiol. 4;18 (1): 126. 2018.

MIN, K. T.; BENZER, S. Wolbachia, normally a symbiont of Drosophila, can be virulent, causing degeneration and early death. Proc Natl Acad Sci USA. 94(20):10792-6. 1997.

MINARD, G.; MAVINGUI, P.; MORO, C. V. Diversity and function of bacterial microbiota in the mosquito holobiont. Parasit Vectors. 6: 146. 2013.

MOLINA-HENAO, E. H.; GRAFFE, M. I.; DE LA CADENA, E. P.; SERRATO, I. M.; CORREA, A.; ROMERO, L. V.; CAICEDO, P. A.; OCAMPO, C. B. Culturable microbial composition in the midgut of Aedes aegypti strains with different susceptibility to dengue-2 virus infection. Simbiose. 80: 85-93. 2020. 
MUTURI, E. J.; BARA, J. J.; ROONEY, A. P.; HANSEN, A. K. Midgut fungal and bacterial microbiota of Aedes triseriatus and Aedes japonicus shift in response to La Crosse virus infection. Mol Ecol. 25, 4075-4090. 2016.

MUTURI, E. J.; DUNLAP, C.; RAMIREZ, J. L.; ROONEY, A. P.; KIM, C. H. Host blood meal source has a strong impact on gut microbiota of Aedes aegypti. FEMS Microbiol Ecol. 95 (1): fiy213. 2019.

MUTURI, E. J.; NJOROGE, T. M.; DUNLAP, C.; CÁCERES, C. A. Blood meal source and mixed blood-feeding influence gut bacterial community composition in Aedes aegypti. Parasites Vectors.14: 83. 2021.

MITRAKA, E.; STATHOPOULOS, S.; SIDEN-KIAMOS, I.; CHRISTOPHIDES, G. K.; LOUIS, C. Asaia accelerates larval development of Anopheles gambiae. Pathogens and global health. 107 (6): 305-311. 2013.

MCGRAW, E. A.; O'NEILL, S.L. Beyond insecticides: new thinking on an ancient problem. Nat Rev Microbiol. 11(3): 181-93. 2013.

OLIVEIRA, J. H. M.; GONÇALVES, R. L. S.; LARA, F. A.; DIAS, F. A.; GANDARA, A. C. P.; et al. Correction: Blood Meal-Derived Heme Decreases ROS Levels in the Midgut of Aedes aegypti and Allows Proliferation of Intestinal Microbiota. PLOS Pathogens 9(2): 10.1371. 2011.

ONYANGO, G. M.; BIALOSUKNIA, M. S.; PAYNE, F. A.; MATHIAS, N, T.; CIOTA, A.; KRAMER, D. L. Increase in temperature enriches heat tolerant taxa in Aedes aegypti midguts. Relatórios Científicos. 2020.

OSEI-POKU, J.; MBOGO, C. M.; PALMER, W. J.; JIGGINS, F. M. Deep sequencing reveals extensive variation in the gut microbiota of wild mosquitoes from Kenya. Mol Ecol. 2012.

RAMIREZ, J. L.; SOUZA-NETO, J.; TORRES COSME, R.; ROVIRA, J, ORTIZ, A.; PASCALE, J. M.; DIMOPOULOS, G. Reciprocal tripartite interactions between the Aedes aegypti midgut microbiota, innate immune system and dengue virus influences vector competence. PLoS Negl Trop Dis 6:e1561. 2012.

RAMIREZ, J. L. et al. Chromobacterium Csp_P Reduces Malaria and Dengue Infection in Vector Mosquitoes and Has Entomopathogenic and In Vitro Anti-pathogen Activities. PLoS Pathog. 10:1-13. 2014.

SHARMA, P.; SHARMA, S.; MAURYA, R. K.; THOMAS, T.; LATA, S. Salivary glands harbor more diverse microbial communities than gut in Anopheles culicifacies. Parasit Vectors. 7:235. 2014.

SOUZA-NETO, J. A.; POWELL, J. R.; BONIZZONI, M. Aedes aegypti vector competence studies: A review. Infect Genet Evol. 67: 191-209. 2019.

STRAND, M. R. The gut microbiota of mosquitoes: Diversity and function. Arthropod Vector: Controller of Disease Transmission, eds Wikel SK, Aksoy S, Dimopoulos G (Academic Press, London). 1:185-199. 2017. 
TERENIUS, O.; LINDH, J. M.; ERIKSSON-GONZALES, K.; BUSSIÈRE, L.; LAUGEN, A. T.; BERGQUIST, H. Midgut bacterial dynamics in Aedes aegypti. FEMS Microbiol Ecol. 80 (3): 556-65. 2012.

VALLE, D.; BELLINATO, D. F.; VIANA-MEDEIROS, P. F.; LIMA, J. B. P.; MARTINS-JUNIOR, A. D. J. Resistance to temephos and deltamethrin in Aedes aegypti from Brazil between 1985 and 2017. Mem Inst Oswaldo Cruz. 114 (3): e180544. 2019.

VALZANIA, L. K. L.; COON, K. J. V.; MARK, R. B.; MICHAEL, R. S. Hypoxia-induced transcription factor signaling is essential for larval growth of the mosquito Aedes aegypti. PNAS. 16; 115 (3): 457-465. 2018.

VIANA, J. L. et al. Isolados de Bacillus thuringiensis de biomas maranhenses com potencial ação inseticida contra larvas de Aedes aegypti (Diptera, Culicidae). Braz. J. Biol. 81 (1):114-124. 2021.

WANG, Y.; GILBREATH, T. M.; KUKUTLA, P.; YAN, G.; XU, J. Dynamic gut microbiome across life history of the malaria mosquito Anopheles gambiae in Kenya. PLoS One. 6 (9): e24767. 2011.

WANG, S.; JACOBS-LORENA, M. Genetic approaches to interfere with malaria transmission by vector mosquitoes. Trends Biotechnol. 31 (3): 185-93. 2013.

YADAV, K. K.; BORA, A.; DATTA, S.; CHANDEL, K.; GOGOI, H. K.; PRASAD, G. B. K. S.; VEER, V. Molecular characterization of midgut microbiota of Aedes albopictus and Aedes aegypti from Arunachal Pradesh, India. Parasit Vectors. 8: 641. 2015.

YADAV, S.; KUMAR, A.; GUPTA, M. Curr Microbiol. 75: 1038. 2018.

ZINK, S. D.; VAN SLYKE, G. A.; PALUMBO, M. J.; KRAMER, L. D.; CIOTA, A. T. Exposure to West Nile virus increases bacterial diversity and immune gene expression in Culex pipiens. Viruses. 7 (10): 5619-31. 2015.

ZOUACHE, K.; RAHARIMALALA, F. N.; RAQUIN, V.; TRAN-VAN, V.; RAVELOSON, L. H.; RAVELONANDRO, P.; MAVINGUI, P. Bacterial diversity of field-caught mosquitoes, Aedes albopictus and Aedes aegypti, from different geographic regions of Madagascar. FEMS Microbiol Ecol. 75 (3): 377-89. 2011.

ZOUACHE, K.; MICHELLAND, R. J.; FAILLOUX, A. B.; GRUNDMANN, G. L.; MAVINGUI, P. Chikungunya virus impacts the diversity of symbiotic bacteria in mosquito vector. Mol Ecol. 21 (9): 2297-309. 2012. 


\section{Capítulo 19}

Detecção de criadouros de Aedes aegypti e Aedes Albopictus (Diptera: Culicidae) em cemitério de Manaus, Amazonas

\section{Fabiane Monteiro da Silva}

\section{Luiz Henrique Fonseca dos Santos}

Gabay Manuel Marques Reis da Silva

Sabrina da Fonseca Meireles

\section{Francimeire Gomes Pinheiro}

Resumo: É comum a infestação de culicídeos em ambientes que fazem parte da nossa convivência. Os cemitérios em particular têm um número elevado de recipientes cheios de água, flores, e fontes permanentes de sangue humano (visitantes e trabalhadores). Nesse contexto, foi realizado a identificação de potenciais criadouros de Aedes aegypti e Aedes albopcitus no cemitério de Nossa Senhora Aparecida, em Manaus, por meio da análise de recipientes dispostos nas sepulturas. Das 33 quadras inspecionadas, foram coletadas amostras em 43.577 túmulos, totalizando 3.487, obtidas nos criadouros no período seco (1.531) e no chuvoso (1.956). Destes, 21 (1,07\%) foram positivos para larvas, apresentando ITR: cerâmica 9 (43,0\%); cimento 5 (23,8\%); granito $4(19,0 \%)$ e plástico $3(14,2 \%)$; e no período seco, 1.531 , com apenas um $(0.06 \%)$ exemplar. No período chuvoso, um total de 1.956 criadouros foram analisados, sendo os recipientes de plásticos mais frequentes (1.034) 52,87\% e os menos frequentes foram de MDF (03) $0,15 \%$ e isopor (02) $0,1 \%$. Já no período de seca, foi obtido cerca de 1.531 vasos, sendo o mais frequente nas sepulturas os vasos de plásticos com 48,67\% (745). Este estudo corrobora com a literatura sobre os criadouros de mosquitos de importância sanitária em cemitérios das grandes cidades. Apenas um cemitério em Manaus foi alvo desta pesquisa. No entanto, estender esta pesquisa para outros cemitérios da cidade é necessário, para compreender melhor a dinâmica e alocação dos criadouros de mosquitos vetores de doenças em cemitérios de Manaus.

Palavras-chave: Aedes, Insetos, Entomologia Médica, Necrópoles. 


\section{INTRODUÇÃO}

A dengue é uma das doenças mais importantes causada por arbovírus que infecta os seres humanos, causando alta taxa de mortalidade em diferentes regiões no mundo (FIGUEIREDO et al., 2004). É uma doença febril aguda, causada por um vírus do gênero Flavivirus, com antigenicidade para quatro sorotipos virais: DENV-1, DENV-2, DENV-3 e DENV-4. Estima-se que entre 2,5 e 3,6 bilhões de pessoas vivem sob ameaça de infecções pelo vírus da dengue. Mais de 50 milhões de pessoas são infectadas no mundo, dois milhões podem evoluir para os estágios mais graves e 21 mil resultam em mortes, anualmente (FERREIRA, 2012).

0 vírus dengue, assim como os arbovírus de importância médica zika, chikungunya e febre amarela urbana, são transmitidos de uma pessoa a outra, principalmente, pela picada da fêmea do mosquito do gênero Aedes durante o repasto sanguíneo. É comum a infestação desses mosquitos em vários ambientes que fazem parte da nossa convivência, como os cemitérios - ambiente semi-isolado, com estruturas propícias para desenvolvimento de vários mosquitos (NATAL; GONÇALVES e TAVEIRA, 1997).

Os cemitérios geralmente estão localizados em áreas urbanas ou periurbanas e, apresentam várias características que facilitam a proliferação de insetos, a saber: os ornamentos e arquitetura rebuscada dos túmulos, que podem permitir o acúmulo de água da chuva; a presença de tanques, destinados ao armazenamento de água para limpeza dos jazigos e; o acúmulo de detritos orgânicos, como restos de folhas e flores, responsáveis pelo entupimento de drenos, propiciando a formação criadouros artificiais, contendo água e matéria orgânica, condições ideais para a criação desses mosquitos (CATÃO, 2011; TEIXEIRA et al., 2009); NATAL; GONÇALVES e TAVEIRA, 1997).

0 controle eficaz de mosquitos de importância médica, como o Ae. aegypti e Ae. albopictus é comprometido pela ineficiência de alguns inseticidas químicos que tem causado resistência, como temefós e deltametrina, além do fator "versatilidade" dessa espécie, na busca de criadouros para depositar seus ovos, que são altamente resistentes ao dessecamento, podendo resistir por vários meses até o momento propício para a eclosão (FRANKIE e EHLER, 1978).

A cidade de Manaus, capital do Amazonas contém seis cemitérios, áreas consideradas vulneráveis para a proliferação de insetos. Estas áreas são conhecidas como Pontos Estratégicos (PEs) e carecem de estudos entomológicos. Nesse contexto, propôs-se a realização do presente trabalho, tendo como objetivo principal, a identificação de potenciais criadouros de Ae. aegypti e Ae. albopictus no cemitério de Nossa Senhora Aparecida, no município de Manaus, AM, por meio da análise de recipientes dispostos nas dependências de sepulturas, com a finalidade de prover dados para ações direcionadas ao controle desse mosquito vetor de doenças. 


\section{REFERENCIAL TEÓRICO}

\subsection{CARACTERÍSTICAS IMPORTANTES DO Aedes aegypti E Aedes albopictus}

O Ae. aegypti (aedes, do grego, odioso e aegypti, do latim, do Egito) é oriundo do Velho Mundo, provavelmente da Etiópia. É possível que sua chegada ao Novo Mundo tenha ocorrido durante o século XV ao XIX, por meio do tráfego marítimo. Está distribuído nas regiões Tropicais e Subtropicais, entre os paralelos de 45ํำ de latitude Norte e $40^{\circ}$ de latitude Sul, sendo raramente encontrado além destes limites (FORATTINI, 2002).

Ae.aegypti pertence à família Culicidae, subfamília Culicinae, gênero Aedes e subgênero Stegomyia. Morfologicamente, a forma adulta apresenta escamas de cor escura, com faixas brancas nas bases dos segmentos tarsais e um desenho em forma de lira no mesonoto. 0 macho se distingue da fêmea por possuir antenas plumosas e palpos mais longos (FORATTINI, 2002).

Já o Aedes (Stegomyia) albopictus Skuse, 1894, conhecido como Tigre asiático, devido sua origem asiática (FORATTINI et al., 1997), tem ocorrência desde o sudeste do continente até os limites com a Cordilheira do Himalaia (FORATTINI, 2002). No mundo sua dispersão ocorreu a partir de 1980 (GOMES, 1999), começando pelos Estados Unidos da América (SPRENGER e WUITHIRANYAGOOL, 1986).

No Brasil, o primeiro registro de Ae. albopictus foi em 1986 no Rio de Janeiro e Minas Gerais (FORATTINI 1986). A inserção desse mosquito no país pode ter ocorrido por meio de transporte passivo de ovos, provavelmente em pneus comercializados do Japão, de acordo com o resultado da análise genética populacional feita por Kambhampati et al. (1991).

No estágio adulto o Ae. albopictus apresenta morfologicamente, no corpo a coloração negra com tarjas claras, e um desenho de escamas branco-prateada, formando uma linha reta e longitudinal ao longo do tórax, características essenciais para sua identificação taxonômica, diferenciando-se do Ae. aegypti que apresenta na mesma estrutura, escamas claras em formato de uma lira (FORATTINI, 2002).

\subsection{CICLO DE VIDA}

Esses mosquitos se desenvolvem em metamorfoses completas, razão pela qual são designados por holometábolos. Apresentam o ciclo de vida composto por quatro fases, a saber: ovo, larva (L1- L4), pupa e adultos (figura 1). Esses insetos apresentam duas etapas de desenvolvimento: uma etapa aquática, que compreende as fases do ovo, larva e pupa, e uma etapa terrestre, que corresponde à vida adulta do mosquito (ROZENDAAL, 1997). 
Figura 1. Representação esquemática do ciclo de vida do Aedes aegypti.

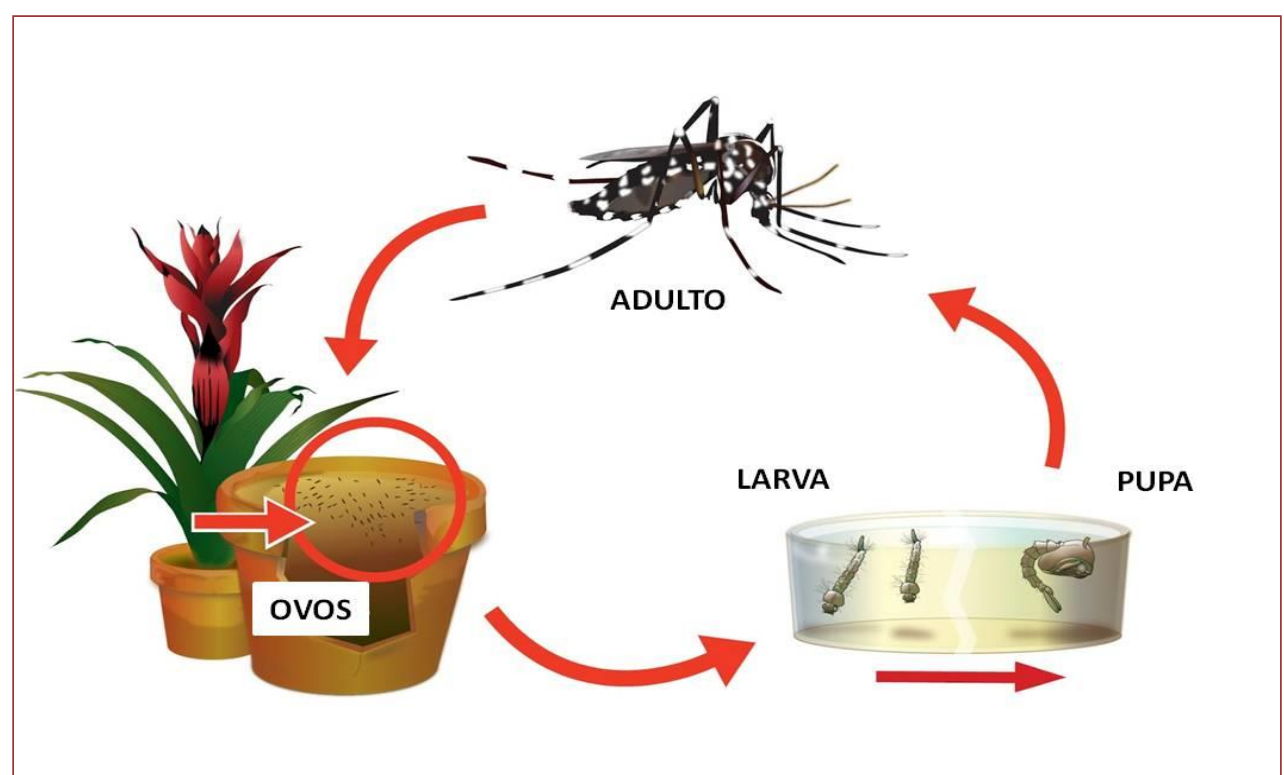

Fonte: SKPTM (2015), adaptado.

\subsubsection{CARACTERÍSTICAS DOS OVOS DE Aedes spp.}

No início do ciclo de vida, as fêmeas ovipõem cerca de 30-300 ovos por postura, dependendo da espécie. Os ovos são colocados isoladamente e fixados nas laterais dos criadouros acima da linha de água em substratos úmidos que, embora não tenham água, poderão ser posteriormente inundados (FORATTINI, 2002). Morfologicamente, os ovos chegam a medir em média $0,4 \mathrm{~mm}$ ou menos de comprimento e apresentam formato aproximadamente ovóide. Inicialmente os ovos são brancos, mas rapidamente adquirem uma cor negra brilhante, que escurecem devido ao contato com o oxigênio. Após o desenvolvimento embrionário, os ovos tornam-se resistentes a dessecação, sendo capazes de resistir por vários anos (CONSOLI e LOURENÇO-DE-OLIVEIRA, 1994).

\subsubsection{LARVAS DE Aedes spp.}

A fase larvária compreende o período de alimentação e crescimento. A alimentação é baseada em matéria orgânica acumulada nas paredes e nos fundos dos criadouros (BRASIL, 2001). O período larvário dos culicídeos em geral, é de quatro estádios (L1-L4), ou seja, ocorrem três mudas, até que a larva de $4^{\circ}$ estádio, o mais longo, que originará a pupa. Em média, a fase larvária ocorre em cinco dias, sendo influenciada pela temperatura, luz, densidade larvária do criadouro e da disponibilidade de alimentos (BRASIL, 2001; FORATTINI, 2002).

\subsubsection{PUPAS DE Aedes spp.}

O estágio de pupa dura de dois a três dias. É nessa fase que ocorre a metamorfose no mosquito. As pupas possuem forma de vírgula, não se alimentam, são bastantes móveis e ficam próxima a superfície da água, para facilitar a emergência do inseto adulto. Inicialmente, as pupas possuem a mesma coloração das larvas, mas vão escurecendo à medida que se aproxima o momento do surgimento do adulto (CONSOLI e LOURENÇO-DE-OLIVEIRA, 1994; BRASIL, 2001). 


\subsubsection{ADULTOS DE Aedes spp.}

Após o endurecimento do tegumento corporal, que ocorre depois da emergência, a fêmea se encontra apta à cópula, sendo necessário apenas uma cópula para à inseminação. Com algumas exceções, a fêmea hematófaga, deve picar um hospedeiro e efetuar uma refeição sanguínea de forma a obter os nutrientes necessários para o desenvolvimento dos ovos (CONSOLI e LOURENÇO-DE-OLIVEIRA, 1998; FORATTINI, 2002).

\subsection{CEMITÉRIO COMO FOCO DE PROLIFERAÇÃO DE MOSQUITOS}

Os cemitérios geralmente são inseridos em áreas populosas que possuem várias características que facilitam a proliferação de mosquitos. Possuem uma elevada densidade de sepulturas, muitas vezes ornamentadas com túmulos de arquitetura rebuscada. A própria forma de construção pode gerar pontos que acumulam água de chuva, formando criadouros. 0 hábito religioso e cultural que levam as pessoas a enfeitarem com flores os túmulos em homenagem aos mortos é outro fator a propiciar o estabelecimento de pontos de proliferação. Numerosos vasos são colocados sobre os túmulos, no terreno, ou nos pequenos jardins que ornamentam os jazigos (VEZZANI, 2007).

Segundo McPherson e Nilon (1987), normalmente, as flores são colocadas nos vasos, os quais são preenchidos com água até um pouco abaixo do transbordamento. Se o conteúdo não é removido depois do murchamento, a própria matéria orgânica das hastes, junto com folhas e fragmentos das flores, acaba caindo no interior do vaso, passando por um processo de apodrecimento. 0 líquido fica rico em microrganismos e matéria orgânica em decomposição. Entende-se que o conteúdo dos vasos passa por diferentes estágios de evolução, envolvendo a degradação do material em seu interior e, por conseguinte, pode ocorrer uma sucessão ecológica relativa às espécies que vão ocupando este habitat.

Em períodos sem chuvas, quando os criadouros normalmente secam, muitos vasos são mantidos com água colocada pelos visitantes que, constantemente, renovam as flores. Em se tratando desta atividade humana, os cemitérios apresentam-se sempre ativos em relação à produção de mosquitos, mesmo em épocas desfavoráveis. Jardins com arvoredos, interiores de capelas, gavetas abertas, frestas e rachaduras são pontos favoráveis ao abrigo de mosquitos adultos (NATAL, GONÇALVES e TAVEIRA, 1997).

\section{MATERIAL E MÉTODOS}

\subsection{LOCAL DE ESTUDO}

0 estudo foi realizado nas dependências do cemitério Nossa Senhora Aparecida, localizado no bairro Tarumã, na Avenida do Turismo, Zona Oeste de Manaus, nos meses de novembro e dezembro de 2016 e; janeiro, junho, julho e agosto de 2017. A área, corresponde ao maior cemitério urbano de Manaus em extensão. Possui 800 mil metros quadrados, contendo 64 quadras e um total de 97.570 sepulturas.

A área foi escolhida por estar circundada por um fragmento florestal, pela existência de substâncias açucaradas (flores das jarras e outra vegetação) e fontes permanentes de sangue humano (visitantes e trabalhadores). 


\subsection{COLETAS DE OVOS E LARVAS}

Foi instalado um total de 25 armadilhas do tipo ovitrampa, composta por recipiente de plástico preto de aproximadamente 1,5 litros, contendo água potável sem atrativo e uma palheta de oviposição de 30 centímetros. As armadilhas foram distribuídas em 17 quadras aleatoriamente e recolhidas após 15 dias. 0 procedimento foi repetido duas vezes no mesmo ponto de coleta.

As palhetas recolhidas foram acondicionadas em sacolas de plástico, para maior proteção dos ovos e transferidas para o Laboratório do INPA. Os ovos, após eclosão tiveram seu desenvolvimento acompanhado por meio de alimentação à base de ração de peixe e, na fase adulta, foram identificados segundo a chave de identificação taxonômica de CONSOLI e LOURENÇO-DE-OLIVEIRA (1994).

Figura 7. Montagem e retirada das armadilhas do tipo ovitrampa: A - Reposição de água; B - Retirada da palheta; C - Palheta acondicionada em saco plástico para transporte; D -

Palhetas imersas para eclosão dos ovos; E - Larvas a espera de emergir o adulto.
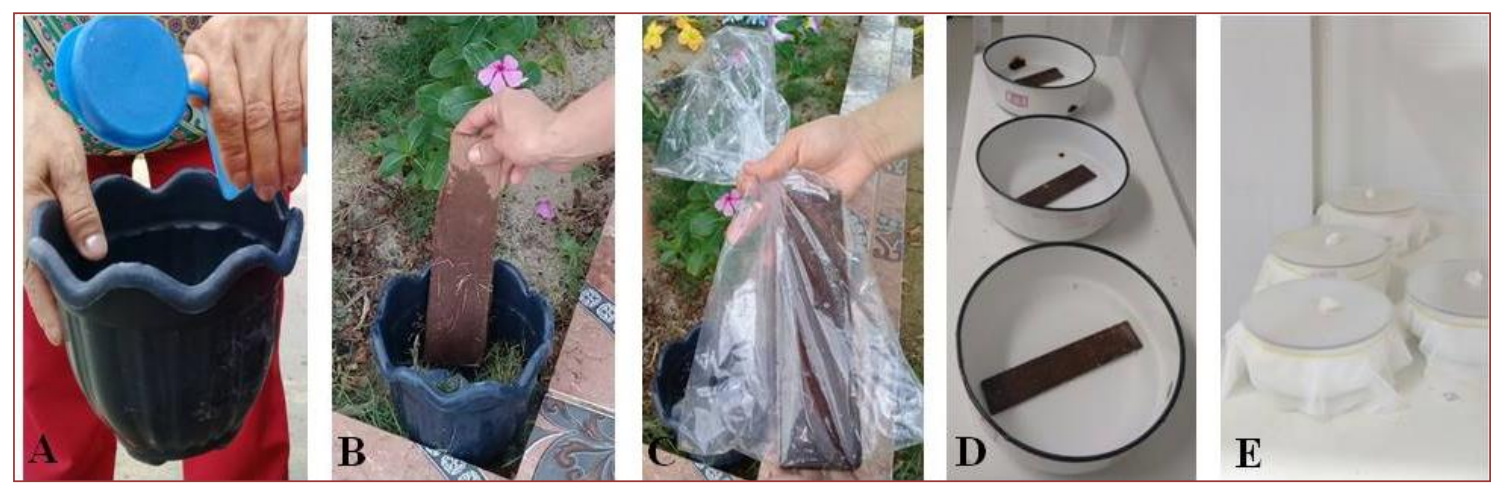

Fonte: Silva, 2017

As larvas foram coletadas em jarros de cerâmica, cimento, granito e plástico sobre as sepulturas. 0 material foi coletado com o auxílio de uma pipeta Pasteur de plástico e acondicionado em tubo Falcon $®$. Em seguida foi feito a triagem dos tubos por quadra e a transferência das amostras para o laboratório do INPA, para acompanhamento do desenvolvimento das larvas, até a sua identificação.

\subsection{CRITÉRIOS DE INCLUSÃO E EXCLUSÃO}

Foram analisadas apenas as dependências internas das sepulturas, incluindo as flores artificiais e os vasos ou vasilhames para acondicionar as flores. Já os utensílios como copos descartáveis e outros objetos que possam acumular água existente na área de estudo que não estavam relacionados à ornamentação das sepulturas, foram excluídos.

\subsection{ANÁLISE DOS DADOS}

Os dados foram mensurados baseados nas informações das armadilhas de oviposição e prospecção dos criadouros. Para isso, foi avaliado o Índice por Tipo de Recipiente (ITR), conforme Brasil (2013). Este índice ressalta a eventual importância de determinado criadouro dentre os positivos e, consequentemente, indica a necessidade de adoção de medidas específicas de controle. 


$$
I T R=\frac{\text { № de tipos de recipientes positivos }}{\text { Total de recipientes positivo }} \mathrm{X} 100
$$

Já os índices de densidade larval (IDL) e de densidade de ovos (IDO), foram calculados para identificar os níveis de densidade e distribuição do vetor nas quadras visitadas. Os IDL e IDO representam o número de larvas e ovos, segundo Gomes (1998), calculados por meio das fórmulas:

$$
\begin{gathered}
I P O=\frac{\text { № de armadilhas positivas }}{\text { № de armadilhas expostas }} \times 100 \\
I D O=\frac{\text { № de ovos eclodidos na palheta por espécies no mês }}{\text { № de armadilhas positivas }} \times 100 \\
I D L=\frac{\text { № de larvas coletadas por espécie no mês }}{\text { № de armadilha positivas }} \times 100
\end{gathered}
$$

\section{RESULTADOS E DISCUSSÃO}

Na primeira coleta de ovos de mosquitos no cemitério Nossa Senhora Aparecida no período chuvoso, das 25 ovitrampas dispostas nas sepulturas, 15 foram positivas, com IPO (Índice de Positividade em Ovitrampa) de 60\%. Na segunda coleta, considerado o intervalo de 15 dias, obteve-se 10 armadilhas positivas com IPO de 40\%. Já no período seco, foram obtidas 10 positivas na primeira coleta com IPO de $40 \%$ e na segunda 14 , com IPO de 56\%. Após o acompanhamento da eclosão dos ovos e desenvolvimento das larvas, foram identificados na fase adulta os mosquitos, prevalecendo a espécie Ae. albopictus.

Nas 33 quadras do cemitério Nossa Senhora Aparecida inspecionados, foram vistoriados 43.577 túmulos, resultando na detecção de 3.487 criadouros de mosquitos, sendo 1.531 no período seco e 1.956 no chuvoso. Destes, 21 (1,07\%) foram positivos para larvas, apresentando os ITR: cerâmica 9 (43,0\%); cimento 5 (23,8\%); granito 4 $(19,0 \%)$ e plástico $3(14,2 \%)$; e no período seco, 1.531 , com apenas um $(0.06 \%)$ exemplar.

Os recipientes, considerados possíveis criadouros de mosquitos foram quantificados. Nos meses de novembro, dezembro (2016) e janeiro (2017), período chuvoso, um total de 1.956 criadouros foram analisados (figura 3). Destes, os recipientes de plásticos foram os mais frequentes, com 52,87\% (1.034), e os menos frequentes foram de MDF (03) 0,15\% e isopor (02) 0,1\%. Já nos meses de junho, julho e agosto de 2017, período de seca, foi obtido cerca de 1.531 vasos, sendo o mais frequente nas sepulturas os vasos de plásticos com 48,67\% (745). Os recipientes MDF e isopor não foram detectados nesse período. 
Figura 8. Quantificação dos diferentes tipos de criadouros analisados conforme estação chuvosa e seca.

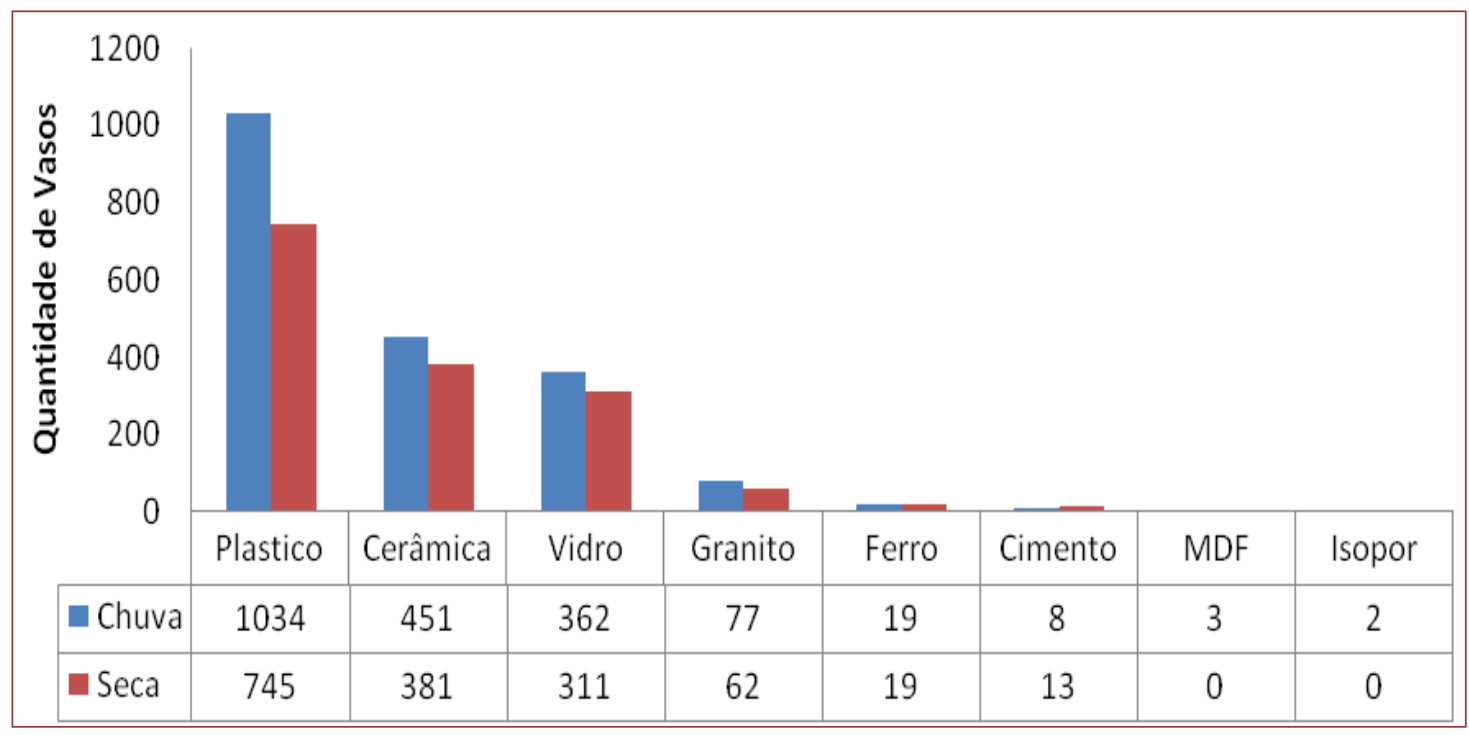

Fonte: dados dos autores

A tabela 1 mostra o percentual de larvas por tipos de recipientes, onde, das 33 quadras inspecionadas na estação chuvosa, 125 larvas foram obtida, sendo 124 para Ae. albopictus e apenas um exemplar de Ae. aegypti. Deste total, 42 (33,6\%) foram encontradas em criadouros de cerâmica; 38 (30,4\%) de cimento; 27 (21,6\%) de plástico e $18(14,4 \%)$ de granito. Os demais criadouros (vidro, ferro, MDF e isopor) não foram observadas larvas.

Tabela 1 - Percentual de ocorrência de formas imaturas em relação ao criadouro artificial prospectado no periodo chuvoso (novembro e dezembro de 2016 e janeiro de 2017).

\begin{tabular}{|c|c|c|c|c|c|}
\hline Criadouros & $\begin{array}{c}\text { No de } \\
\text { criadouros } \\
\text { encontrados }\end{array}$ & $\begin{array}{c}\text { No de } \\
\text { criadouros } \\
\text { positivos }\end{array}$ & No de larvas & ITR (\%) & $\begin{array}{c}\% \text { de } \\
\text { larvas/criadouro }\end{array}$ \\
\hline Plástico & 1034 & 03 & $27(21,6 \%)$ & 14,2 & 2,6 \\
\hline Cerâmica & 451 & 09 & $42(33,6 \%)$ & 43,0 & 9,3 \\
\hline Vidro & 362 & - & - & - & - \\
\hline Granito & 77 & 04 & $18(14,4 \%)$ & 19,0 & 23,3 \\
\hline Ferro & 19 & - & - & - & - \\
\hline Cimento & 08 & 05 & $38(30,4 \%)$ & 23,8 & 475 \\
\hline MDF & 03 & - & - & - & \\
\hline Isopor & 02 & - & - & - & \\
\hline Total & 1956 & 21 & 125 & & \\
\hline
\end{tabular}

Na tabela 2 observa-se o percentual de larvas por tipos de recepientes, inspecionadas na estação seca, onde foram obtidos um total de 22 larvas de Ae. albopictus encontradas apenas em criadouros de cerâmica. Em relação ao ITR, obteve-se em criadouros de cerâmica $1 \%$. 
Tabela 2 - Percentual de ocorrência de formas imaturas em relação ao criadouro artificial prospectado no período seco (junho, julho e agosto de 2017).

\begin{tabular}{|c|c|c|c|c|c|}
\hline Criadouros & $\begin{array}{l}\text { No de criadouros } \\
\text { encontrados }\end{array}$ & $\begin{array}{c}\text { No de } \\
\text { criadouros } \\
\text { positivos }\end{array}$ & $\begin{array}{l}\text { No de } \\
\text { larvas }\end{array}$ & ITR (\%) & $\begin{array}{c}\% \text { de } \\
\text { larvas/criadouro }\end{array}$ \\
\hline Plástico & 745 & - & - & - & - \\
\hline Cerâmica & 381 & 01 & $22(100 \%)$ & $100 \%$ & 5,77 \\
\hline Vidro & 311 & - & - & - & - \\
\hline Granito & 62 & - & - & - & - \\
\hline Ferro & 19 & - & - & - & - \\
\hline Cimento & 13 & - & - & - & - \\
\hline MDF & - & - & - & - & - \\
\hline Isopor & - & - & - & - & - \\
\hline Total & 1.531 & 01 & 22 & & \\
\hline
\end{tabular}

A dengue é uma arbovirose que se tornou um problema de saúde pública mundial, sendo responsável por causar epidemias principalmente em regiões tropicais, onde condições sociais, climáticas, ecológicas e ambientais favorecem a proliferação dos vetores Ae. aegypti e Ae. albopictus, contribuindo com a circulação viral (TEIXEIRA, 2008; SOUZA e LEITE, 2010).

Os cemitérios são considerados fortes fontes de mosquitos, principalmente por dispor de recursos úteis para o desenvolvimento do mesmo (VEZZANI, 2007). Os cemitérios geralmente têm números elevados de recipientes cheios de água e fontes permanentes de sangue humano (visitantes e trabalhadores). Essas características os tornam habitats urbanos favoráveis para a proliferação de Aedes. Estudos realizados em cemitérios da Flórida (O'MEARA et al., 1992), Manila (SCHULTZ, 1989) e Caracas (BARRERA-R, MACHADO-ALLISON E BULLA, 1979) demonstraram alta densidade de mosquitos desse gênero nesses locais.

O cemitério Nossa Senhora Aparecida está localizado próximo a um fragmento florestal, local favorável para o desenvolvimento de culicídeos. Além disso, nesse ambiente é necessário o armazenamento de água para limpeza dos jazigos e; por ser um ambiente com circulação de trabalhadores e visitantes, serve acidentalmente de alimento para as fêmeas dos mosquitos, que são hematófagas, e permitem a conclusão do seu ciclo de vida (NATAL; GONÇALVES \& TAVEIRA, 1997; ABE et al., 2005).

$\mathrm{Na}$ primeira etapa deste trabalho foi caracterizado e quantificado os tipos de recipientes mais comuns no cemitério para ornamentação das sepulturas. 0 plástico foi o tipo de recipiente mais encontrado com 52,87\%. Já o recipiente mais propício ao desenvolvimento das larvas de Aedes foi o de cerâmica com o ITR (43,0\%). No entanto, estudo semelhante realizado em cemitérios na Venezuela por Abe et al. (2005), observaram a maior frequência de imaturos em recipientes de cimento.

Silva et al. (2006) na cidade do Rio de Janeiro, também mostraram a presença das fêmeas de Ae. albopictus e Ae. aegypti em vários tipos de criadouros. Os autores concluíram que a densidade desses recipientes pode refletir diretamente na contribuição para a produção de indivíduos adultos e, portanto, assumir importância distinta em determinada região.

A predominância de Ae. albopictus neste trabalho já era esperada, em virtude de o cemitério estar localizado próximo a um fragmento florestal, habitat preferencial dessa 
espécie. Tal fato também foi observado por Lopes et al. (2004) onde o Ae. albopictus apresentou-se em maior quantidade em Jacarezinho - PR, município com maior porcentagem de população na área rural.

No ambiente natural, as populações de mosquitos estão sujeitas à influência de diversos fatores bióticos e abióticos, dentre elas a disponibilidade de recursos, microhabitats e a pluviosidade (GLASSER e GOMES, 2002; SERPA et al., 2006), tendo o Ae. aegypti preferência por ambientes urbanos e o Ae. albopictus por ambientes silvestres (GOMES et al., 2005; SILVA et al., 2004).

Neste estudo, foram distribuídas 25 armadilhas ao longo do cemitério, com duplicata a cada 15 dias. No período chuvoso, foi registrado o IPO médio de $50 \%$ e no seco de 48\%. Para Gomes (1998; 2002), o ovo detectado nas palhetas permite calcular a infestação de um local por meio do IPO, o qual traduz a distribuição espacial da infestação em uma localidade. Por outro lado, por meio da contagem dos ovos de cada palheta foi possível calcular ainda o Índice de densidade de ovos (IDO), que indica os períodos de maior e menor reprodução das fêmeas.

A primeira coleta no período chuvoso resultou no IDO de $34,2 \%$ e no IDL de 29,3\%. Enquanto na duplicata não foram encontradas palhetas positivas para ovos, mas para larvas o IDL foi de 33,8\%. De acordo com o trabalho de Monteiro (2014), em Macapá, a correlação do IPO e IDO com a pluviosidade foi significativa após duas semanas, pois este é o período necessário para que as formas imaturas se desenvolvam até a fase adulta e posterior oviposição, positivando as armadilhas. Outro fator que pode contribuir para não relação entre a pluviosidade com o IPO e IDO é quando estes índices entomológicos são elevados, mantido por condições ambientais favoráveis, principalmente a presença de criadouros permanentes, a pluviosidade pode não influenciar na presença e densidade do vetor.

\section{CONCLUSÃO}

Os recipientes oriundos de sepulturas do cemitério Nossa Senhora Aparecida, localizado em Manaus, foram caracterizados e quantificados. Os recipientes de plástico, granito, cerâmica e cimento, foram propícios para o desenvolvimento da fase aquática de mosquitos do gênero Aedes. E, a espécie predominante nesses criadouros foi o Ae. albopictus. Estes resultados trazem a problemática sobre a disponibilidade de vasos nos jazigos, hábito intrínseco da sociedade. Estes dados são de apenas um cemitério em Manaus, considerando a disponibilidade de outros cinco cemitérios, mais estudos são necessários, para se ter uma visão geral do papel desses recipientes na proliferação dos vetores da dengue, zika e chikungunya. 


\section{REFERÊNCIAS}

ABE, M.; MCCALL, P.J.; LENHART, A.; VILLEGAS, E.; KROEGER, A. The Buen Pastor Cemetery in Trujillo, Venezuela: measuring dengue vector output from a public area. Tropical Medicine and International Health. 10: 597-603. 2005.

BARRERA-R; MACHADO-ALLISON, C. E.; BULLA, L. A. Criaderos, densidad larval y segregacion de nicho en tres Culicidaes urbanos (Culex fatigans WIED., C. corniger THEO. y Aedes aegypti L.) en el cemeterio de Caracas. Acta Cient Venez. 30: 418-424. 1979.

BRASIL. Ministério da Saúde. Dengue instruções para pessoal de combate ao vetor: manual de normas técnicas. FUNASA. Brasília. 84p. 2001.

BRASIL. Ministério da Saúde. Levantamento rápido de índices para Aedes aegypti LIRAa - para vigilância entomológica do Aedes aegypti no Brasil, Brasília. 2013.

CATÃO, R. C. Dengue no Brasil: Abordagem geográfica na escala nacional. Dissertação (Mestrado em Geografia) - Faculdade de Ciências e Tecnologia, Universidade Estadual Paulista “Júlio Mesquita Filho", Presidente Prudente. 169p. 2011.

CONSOLI, R. A. G. B.; LOURENÇO-DE-OLIVEIRA, R. Principais Mosquitos de Importância Sanitária no Brasil (1. ${ }^{a}$ Reimpressão), Editora Fiocruz, Rio de Janeiro, 228p. 1994.

FIGUEREDO, R. M. P. DE.; THATCHER, B. D.; LIMA, M. L. DE.; ALMEIDA, T.C.; ALECRIM, W. D.; GUERRA, M.V. DE F. Doenças exantemáticas e primeira epidemia de dengue ocorrida em Manaus, Amazonas, no período de 1998-1999. Rev da Soc Bras de Med Trop, 37(6): 476-479. 2004.

FORATTINI, O. P. Identificação de Aedes (Stegomyia) albopictus (Skuse) no Brasil. Rev Saúde Pública. 20: 244-5. 1986.

FORATTINI, O. P.; SALlUM, M. A. M.; MARQUES, G. R.; FLORES, D. C. Description of the eggs of Anopheles (Kerteszia) laneanus and Anopheles (Nyssorhynchus) antunesi (Diptera: Culicidae) by scanning electron microscopy. J Am Mosq Control Assoc. 13: 368374. 1997.

FORATTINI, O. P. Culicinae: Aedini in Culicidologia Médica. São Paulo: editora da USP. 2: 403-484. 2002.

FRANKIE, G. W.; EHLER, L.E. Ecology of insects in urban environments. Ann Rev Entomol. 23: 367-387. 1978.

GLASSER, C. M.; GOMES, A. C. Clima e sobreposição da distribuição de Aedes aegypti e Aedes albopictus na infestação do Estado de São Paulo. Revista Saúde Pública. 36: 166172. 2002.

GOMES, A. C. Medidas dos níveis de infestação urbana para Aedes (Stegomyia) aegypti e Aedes (Stegomyia) albopictus. Informe Epidemiológico do SUS. 7 (3): 49-57. 1998.

GOMES, A. C.; BITTENCOURT, M. D.; NATAL, D.; PINTO, P. L. S.; MUCCI.; L. F.; PAULA.; M. B. Aedes albopictus em área rural do Brasil e implicações na transmissão de febre amarela silvestre. Rev Saúde Pública. 33: 95-7. 1999. 
GOMES, A. C. Vigilância Entomológica. Informe Epidemiológico do Sistema Único de Saúde. 11: 79-90. 2002.

GOMES, A. C.; SOUZA, J. M.; BERGAMASCHI, D. P.; SANTOS, J. L.; ANDRADE, V. R.; LEITE, O. F. Anthropophilic activity of Aedes aegypti and of Aedes albopictus in area under control and surveillance. Revista Saúde Pública. 39: 206-210. 2005.

KAMBHAMPATI, S.; BLACK IV, W. C.; RAI, K. S. Geographic origin of the US and Aedes albopictus inferrede from allozyme analysis. Heredity. 67: 85-93. 1991.

LOPES, J.; MARTINS, E. A. C.; OLIVEIRA, O.; OLIVEIRA, V.; OLIVEIRA NETO, B. P.; OLIVEIRA, J. E. Dispersion of Aedes aegypti (Linnaeus, 1762) and Aedes albopictus (Skuse, 1894) in the rural zone of north Paraná State. Braz. Arch. Biol. Technol. 47: 739-746. 2004

MCPHERSON, E. G.; NILON, C. H. A habitat suitability index model for a Gray Squirrel in an urban cemetery. Lands. J. 6: 21-30. 1987.

MONTEIRO, F. J. C. Monitoramento da dispersão de Aedes (Stegomyia) aegypti (Linnaeus, 1762) (Diptera: Culicidae) e da dengue no munícipio de Macapá, Amapá, Brasil. Tese apresentada ao Programa de Pós-Graduação em Biodiversidade Tropical da Universidade Federal do Amapá/ Embrapa-Amapá /IEPA/ Conservação Internacional, para obtenção do título de Doutor em Biodiversidade Tropical, área de concentração Ecologia e Meio Ambiente. 2014.

NATAL, D.; GONÇALVES, E. F. B.; TAVEIRA, L. A. Proliferação de mosquitos (Diptera, Culicidae) em cemitérios e perspectivas de controle. Informe Epidemiológico do SUS. 6: 103-110.1997.

O'MEARA, G. F.; GETTMAN, A. D.; EVANS JR., L. F.; SCHEEL F. D. Invasion of cemeteries in Florida by Aedes albopictus. Journal of the American Mosquito Control Association. 8 (1): 1-10. 1992.

ROZENDAAL, J. A. Vector Control: Methods for Use by Individuals and Communities. World Health Organization, Geneva. 412p. 1997.

SERPA, L. L. N.; COSTA, K. V. R. M.; VOLTOLINI, J.C.; KAKITANI, I. Variação sazonal de Aedes aegypti e Aedes albopictus no município de Potim, São Paulo. Revista de Saúde Pública. 1-6. 2006.

SILVA, H. H. G.; SILVA, I.; SANTOS, R. M. G.; FILHO, E. R.; ELIAS, C. N. Atividade larvicida de taninos isolados de Magonia pubescens St. Hil. (Sapindácea) sobre Aedes aegypti (Diptera, Culicidae). Rev. Soc. Bras. Med. Trop. 37: 396-399. 2004.

SILVA, V. C.; SCHERER, P. O.; FALÇÃO, S. S.; ALENCAR, J.; CUNHA, S. P.; RODRIGUES, I. M.; PINHEIRO, N. L. Diversidade de criadouros e tipos de imóveis frequentados por Aedes albopictus e Aedes aegypti. Rev. Saúde Pub.40: 6. 2006.

SOUZA, A.; LEITE, J. C. J. A dengue no município de Santo Amaro: aplicação de geoprocessamento para diagnóstico e análise dos casos. In: Congresso de pesquisa e 
inovação da rede norte nordeste de educação tecnológica. 2010, Salvador. Resumos. Salvador: CONNEPI. 2010.

SCHULTZ, G. W. Cemetery vase breeding of dengue vectors in Manila, Republic of the Philippines. J.Amer. Mosq. Control Assoc. 5: 508-513. 1989.

SPRENGER, D. \& WUITHIRANYAGOOL, T. The discovery and distribution of Aedes albopictus in Harris County, Texas. J. Amer. Mosq. Control. Assoc. 2: 217-9. 1986.

TEIXEIRA, M. G.; COSTA, M. D. C. N.; BARRETO, F.; BARRETO, M. L. Dengue: twenty-five years since reemergence in Brazil. Cadernos de Saúde Pública. 25: S7-S18. 2009.

VEZZANI, D. Artificial container-breeding mosquitoes and cemeteries: a perfect match. Trop. Med. Int. Hlth.12: 199-313. 2007. 


\section{Capítulo 20}

Construção de um banco de cDNA de Aedes albopictus (Diptera: Culicidae) contaminado com semissintéticos do dilapiol

\section{Sabrina da Fonseca Meireles}

Ana Cristina da Silva Pinto

Míriam Silva Rafael

Resumo: 0 Aedes albopictus é um mosquito invasor que se tornou um vetor importante dos vírus Dengue, Zika e Chikungunya. Na ausência de terapia antiviral específica ou vacina, a intensiva aplicação de inseticidas químicos tem causado preocupação, devido aos relatos de resistência. Neste estudo foi feito a construção de um banco de cDNA a partir do RNA total de larvas de 30 estádio de Ae. albopictus submetidas aos derivados semissintéticos do dilapiol: éter etil dilapiol (EED) e éter $n$-butil dilapiol (EBD), por duas gerações consecutivas. O RNA total de Ae. albopictus foi extraído e validado a partir da amplificação do cDNA (cópia filamentar do RNA mensagem) com o primer da Glutationa S-transferase (GSTe2), tendo bom rendimento e qualidade, por meio da PCR clássica. Este banco de cDNA permitirá a quantificação dos níveis de genes de resistência a inseticidas de origem vegetal aplicados em Ae. albopictus posteriormente, como um potencial alternativo ao controle desse mosquito.

Palavras-Chave: Arbovírus, Dengue, GSTe2, RNA total, PCR clássico. 


\section{INTRODUCĈ̃O}

O Aedes (Stegomyia) albopictus, Skuse, 1894, tem competência vetorial para cerca de 26 arbovírus (PAUPY et al., 2009.) Dentre estes, os de maior importância no Brasil são os vírus da Dengue, Febre amarela e Febre chikungunya (ALENCAR et al., 2008). No Brasil não há relatos de surtos envolvendo a transmissão da dengue pelo Ae. albopictus, mas este é considerado um importante vetor envolvido na transmissão dessas arboviroses na Ásia e na África (GUZMÁN e KOURI 2001, ISHAK et al., 2016).

A dengue é transmitida por meio da picada da fêmea do mosquito do gênero Aedes, infectada com o vírus do gênero Flavivirus da familia Flaviridae (KUHN et al., 2002). São registrados cerca de 500.000 casos de dengue por ano, dos quais aproximadamente 22.000 levam os indivíduos infectados a óbito, em uma área de risco de infecção que engloba mais de 2,5 bilhões de pessoas, nas regiões tropicais e subtropicais do Mundo (WHO, 2010).

O controle vetorial de mosquitos de importância médica atualmente, é baseado na utilização dos inseticidas químicos, temefós e deltametrina. No entanto, os mosquitos têm apresentado resistência, o que pode estar relacionado a uma redução na taxa de penetração do inseticida ou em seu metabolismo (VALLE et al., 2019). Nesse sentido, pesquisas alternativas, utilizando compostos naturais à base de plantas, óleos essenciais e/ou seus derivados, têm emergido, para o controle de mosquitos vetores de doenças (MEIRELES et al., 2016; SANTOS et al., 2020).

Estudos toxicológicos e de genotoxicidade de biomarcadores, voltados ao controle de mosquitos, têm apresentado resultados promissores (DOMINGOS et al., 2014, SANTOS et al., 2020). Meireles et al. (2016) observaram alta mortalidade de larvas de Ae. albopictus, após exposição aos derivados do dilapiol éter etil dilapiol (EED) e éter $n$-butil dilapiol (EBD). Nesse sentido, foi construído uma biblioteca de cDNA de larvas de Ae. albopictus contaminadas com o EED e EBD, por duas gerações, para posterior quantificação dos níveis de expressão de genes de resistência, ainda não confirmado nessa espécie.

\section{REFERÊNCIAL TEÓRICO}

\subsection{ASPECTOS BIOLÓGICOS DO Ae. albopictus}

O Ae. albopictus tem sua origem na Ásia e se propagou pelo mundo a partir de 1980 (GOMES et al., 1999). No Brasil o primeiro relato de sua presença foi em 1986 no Rio de Janeiro (FORATTINI, 1986) e, em 1996 na região amazônica, (VÉLEZ et al., 1998), onde obteve sucesso adaptativo às condições ecológicas locais. Esses mosquitos são encontrados principalmente nas regiões periurbanas, relacionado geralmente a áreas com vegetação conservada (FORATTINI, 2002), que o torna um risco em potencial, perante a inserção da população nessas áreas.

Os culicídeos em geral, tem o ciclo de vida constituído por quatro estágios: ovo, larva (L1-L4), pupa e adulto. 0 adulto apresenta no corpo a coloração negra com tarjas claras, e um desenho de escamas branco-prateada, formando uma linha reta e longitudinal ao longo do tórax, características morfológicas importantes na identificação taxonômica (Figura 1) (CONSOLI e LOURENÇO-DE-OLIVEIRA, 1994). 
Figura 9. Fêmea de Ae. albopictus realizando o repasto sanguíneo em humano.

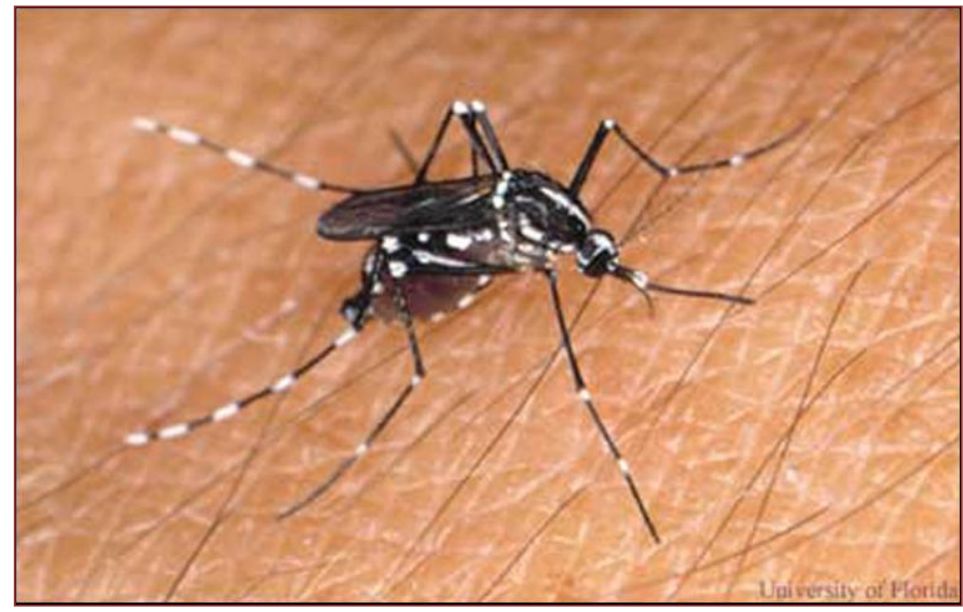

Fonte: CASTNER, UF/IFAS (2018).

A fêmea apresenta hábito alimentar eclético, podendo ser crepuscular ou diurno, tendo como principais hospedeiros, as aves e o homem (CONSOLI e LOURENÇO-DEOLIVEIRA, 1994). A fêmea do mosquito adulto, fase na qual transmite as cepas virais, geralmente faz o primeiro repasto sanguíneo após dois dias de emersão, uma dieta importante para a maturação dos ovos (CONSOLI e LOURENÇO-DE-OLIVEIRA, 1994).

Após a cópula, as fêmeas ovipõem seus ovos em pequenas coleções de água parada de recipientes artificiais como pneus, tampinhas de garrafas, garrafas plásticas, de vidro ou outros recipientes artificiais, ou em habitat natural como: troncos ocos de árvores, tocos de bambu e tanques de bromélias (FORATTINI, 2002). Os ovos são colocados na parede de recipientes e podem permanecer viáveis por pelo menos dois anos, até que o ambiente seja favorável para a eclosão (SILVA et al., 1998).

\subsection{CONTROLE VETORIAL E RESISTÊNCIA A INSETICIDAS}

O controle de insetos causadores de doenças em humanos ou de pragas agrícolas é realizado por meio da aplicação de agentes químicos ou biológicos, como: inseticidas, pesticidas ou praguicidas (RITTER, 1997). O primeiro inseticida utilizado em grande escala comercial para o controle de populações de mosquitos foi o organoclorado DDT (dicloro fenil tricloroetano) em 1946 (BEATY e MARQUARDT, 1996).

Outras classes de inseticidas com atividades neurotóxicas surgiram, como os organofosforados, utilizados de forma contínua no Brasil desde 1967 e, o temefós larvicida aplicado na água potável mais utilizado no período de 2003 a 2014, em praticamente todas as regiões brasileiras, selecionando indivíduos resistentes (VALLE et al., 2019). Após a confirmação do desenvolvimento de resistência ao temefós outros compostos contra larvas foram adotados, como Bacillus thuringiensis var. israelensis (Bti) e reguladores de crescimento de insetos (IGRs) (OMS, 2017; VALLE et al., 2019).

A busca por novos inseticidas para o controle de pragas e vetores de doenças que causem menos impactos à saúde humana e ao meio ambiente tem sido amplamente estudada, utilizando extratos de plantas e seus derivados (PARK et al., 2002). Exemplos de bioenseticidas com eficácia comprovada para o controle de vetores são os constituintes químicos extraídos de plantas do gênero Piper, como as do grupo amina: isobutilamidas, piperidina e pirrolidina (SENGUPTA e RAY, 1987), e do grupo da 
fenilpropanóides: monolignólides como o apiol, miristicina, eugenol, safrol, dímeros de fenilpropanoides e dilapiol (BERNARD et al., 1995; RAFAEL et al., 2008).

O dilapiol, obtido do óleo essencial da planta Piper aduncum é um éter fenílico que tem atividade fungicida, moluscicida, acaricida, bactericida e larvicida comprovada (Figura 2) (SILVA, 2004). Estudos com dípteros utilizando o óleo essencial de dilapiol tem apresentado toxicidade em Drosophila melanogaster, e em algumas espécies do gênero Aedes como em Ae. atropalpus (BELZILE et al., 2000) e Ae. aegypti (RAFAEL et al., 2008).

Figura 10. Fórmula química do dilapiol.

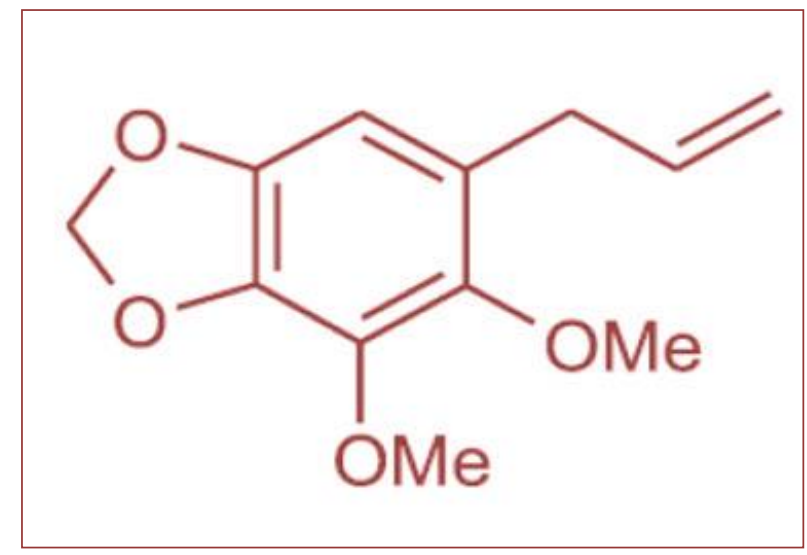

Oliveira et al. (2005).

Os derivados semissintéticos do dilapiol: isodilapiol, éteres metil, etil, propil, butil e octil dilapiol e o epóxido dilapiol tem atividade adulticida em Ae. aegypti comprovada (PINTO, 2012). Já os semissintéticos: E-isodilapiol (ED), éter metil dilapiol (EMD), éter etil dilapiol (EED) e éter $n$-butil dilapiol (EBD) têm atividade ovicida, larvicida e mutagênica em ovos e larvas de Ae. aegypti (DOMINGOS et al., 2014; SANTOS et al., 2020) e em Ae. albopictus (MEIRELES et al., 2016).

\subsection{GENES DE DESINTOXICAÇÃO}

A definição de resistência é a tolerância de uma população de mosquitos a certas doses de inseticidas, que em circunstâncias normais causaria sua morte. Os mecanismos de resistência dos mosquitos aos inseticidas favorecem o significativo aumento do metabolismo dos produtos não tóxicos ou a diminuição dos sítios alvo da sensibilidade, além da redução das taxas de penetração do inseticida e o aumento das taxas de excreção do inseticida (FERRARI et al., 1996).

Estudo realizado na mosca doméstica sobre o mecanismo de redução das taxas de penetração do inseticida pela cutícula, mostrou baixo nível de resistência quando comparado com outros tipos de mecanismos de resistência (OPPENOORTH, 1985). Nesse sentido, há enzimas produzidas por insetos, que degradam, solubilizam e metabolizam compostos xenobióticos (HEMINGWAY, 2000; HEMINGWAY et al., 2004; BRAGA e VALLE, 2007; RUSSELL, 2011).

Os mosquitos vetores de doenças tem apresentado resistência a praticamente todas as classes de inseticidas (BROGDO et al., 1998). E podem sofrer alterações estruturais para aumentar a capacidade de detoxificar diversos inseticidas. Estudos 
mostram que os genes ortólogos de detoxificação de mosquitos envolvidos em processos metabólicos estão em constante evolução (RANSON, 2002; STRODE, 2008). Provavelmente a diversidade desses genes de detoxificação facilita a adaptação de mosquitos em seus nichos e possibilita a sua sobrevivência após exposição aos agentes xenobióticos (STRODE, 2008).

A família das Glutationa S-transferases (GST) é um grupo de diversas enzimas encontradas na natureza, com função de detoxificação de vários xenobióticos e proteção contra o estresse oxidativo (PREPANTHADARA et al., 1996; YANG et al., 2001). Em estudos de resistência aos inseticidas sintéticos: organoclorados, organofosforados, carbamatos e piretróides através das enzimas GSTs, esterases e citocromo P450 tem mostrado aumento da detoxificação em D. melanogaster (TANG e TU, 1994) e em Nilaparvata lugens (VONTAS et al., 2002). Em mosquitos vetores de doenças, foi registrado resistência aos organoclorados a partir da análise da expressão do gene epsilon da GST em An. gambiae (RANSON et al., 2001) e em Ae. aegypti (LUMJUAN et al., 2005).

\section{MATERIAL E MÉTODOS}

\subsection{CAPTURA DE MOSQUITOS E FORMAÇÃO DE COLÔNIA F1}

Espécimes de Ae. albopictus foram coletados com o auxílio de ovitrampas no bairro Aleixo, (03 05'730" S, 59 o 59'183" W), em Manaus, Amazonas e, encaminhados para o insetário da Coordenação de Sociedade, Ambiente e Saúde COSAS-INPA. As larvas foram alimentadas com ração balanceada para peixe Tetra Cichlid; os adultos após emergidos foram identificados com a chave taxonômica de Consoli e Lourenço-deOliveira (1994); alimentados com solução açucarada a 10\% (H20 + açúcar comercial) e com sangue de Hamster (Mesocricetus aureatus), este último somente para as fêmeas. Em seguida, casais foram formados para cruzamento e obtenção da colônia F1.

\subsection{SÍNTESE DOS DERIVADOS DO DILAPIOL}

Os semissintéticos: éter etil dilapiol (EED) e éter $n$-butil dilapiol (EBD) (Figura 3), são derivados semissintéticos do dilapiol, obtidos por reação de oximercuriação realizado por Pinto (2008), no Laboratório de Pesquisa em Produtos Naturais (CPPN) do Instituto Nacional de Pesquisas da Amazônia (INPA) em Manaus, Estado do Amazonas.

Figura 11. Estrutura química dos derivados semissintéticos. A - Éter etil dilapiol; B - Éter n-butil dilapiol.

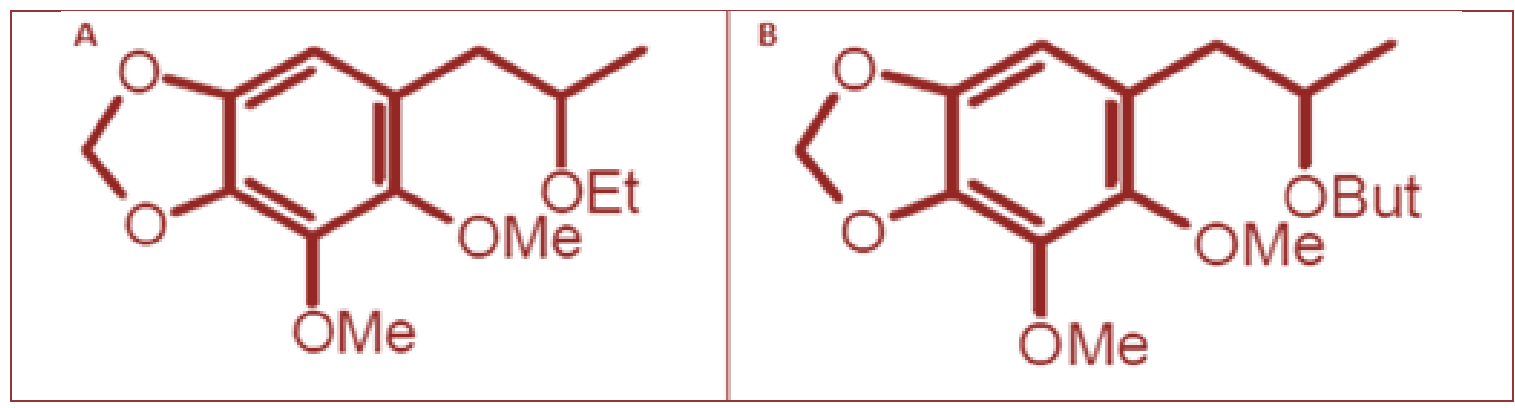

Pinto (2008). 


\subsection{BIOENSAIO}

As concentrações utilizadas de cada composto foram baseadas na concentração letal para 50\% dos expostos ( $L_{50}$ ), sendo escolhidas duas concentrações inferiores a $\mathrm{CL}_{50}$ para cada composto. A escolha de concentrações menores e por curtos períodos de exposição (4 horas) foi adotada para viabilizar a sobrevivência das larvas após o bioensaio para congelamento.

Foram utilizadas 250 larvas de $3^{\text {o }}$ estádio para cada tratamento da geração $\mathrm{F} 1$, divididas em três réplicas, nas concentrações 50 e $70 \mu \mathrm{g} / \mathrm{mL}$ do EED e 12, 5 e $20 \mu \mathrm{g} / \mathrm{mL}$ do EBD, além de um controle negativo $\left(\mathrm{H}_{2} \mathrm{O}+\mathrm{DMSO}\right)$. As larvas foram expostas por quatro horas, em ambiente com temperatura e umidade controladas $\left(26-28{ }^{\circ} \mathrm{C} / 70-80 \%\right.$ de umidade).

\subsection{CONGELAMENTO E FORMAÇÃO DA COLÔNIA F2}

Após o bioensaio, 60 larvas em triplicata (sendo 3 pools com 20 larvas), para cada tratamento, foram congeladas em nitrogênio líquido e armazenadas em freezer $80{ }^{\circ} \mathrm{C}$ negativos, para posterior extração de RNA total. As outras 190 larvas sobreviventes foram transferidas para água potável; alimentadas e; na fase adulta, foram formados casais para cruzamento e produção da próxima geração (F2).

\subsection{EXTRAÇÃO DE RNA TOTAL}

Na extração de RNA total, foi utilizado o kit RNeasy® Plant Mini (Quiagen® cat. № 74904 adaptado para Ae. albopictus), seguindo as instruções do fabricante. Em seguida foi feito a quantificação do RNA total extraído em aparelho espectrofotômetro, que gerou aproximadamente $500 \mathrm{ng} / \mathrm{uL}$ de RNA de cada extração. Para eliminar os contaminantes (DNA) das amostras, foi utilizado o kit TURBO DNA-free ${ }^{\circledR}$ Ambion $\AA$ adaptado para Ae. albopictus. E, para verificar a integridade do RNA total, foi feito um gel desnaturante de agarose a 1\% em tampão MOPS 1X.

\subsection{SÍNTESE DA FITA DE CDNA E VALIDAÇÃO DO BANCO DE cDNA}

No procedimento para a síntese da fita complementar de RNA mensageiro (cDNA) foi utilizado o kit Promega, segundo as instruções do fabricante. A integridade do cDNA foi verificada através de gel de agarose a 1\% em tampão TEB 1X, por eletroforese horizontal a 70V, 80 ma., por 45 minutos, seguida de fotodocumentação. E, a validação foi feita por meio da PCR clássica, utilizando o primer GSTe2.

\section{RESULTADOS E DISCUSSÃO}

Um total de 20 pools de RNA total foram extraídos, obtendo-se na maioria das amostras mais de 500 ng de RNA total com absorbâncias 260/280 (>2) e 260/230 (>1). A figura 4 mostra a integridade do RNA total extraído do Ae. albopictus de uma das três réplicas, contendo as subunidades ribossômicas $18 \mathrm{~S}$ e $32 \mathrm{~S}$ visíveis desse mosquito. 
Figura 12. Eletroforese da extração de RNA total em gel de agarose a 1\% de amostras quantificadas de Ae. albopictus, mostrando a integridade do RNA total extraído.

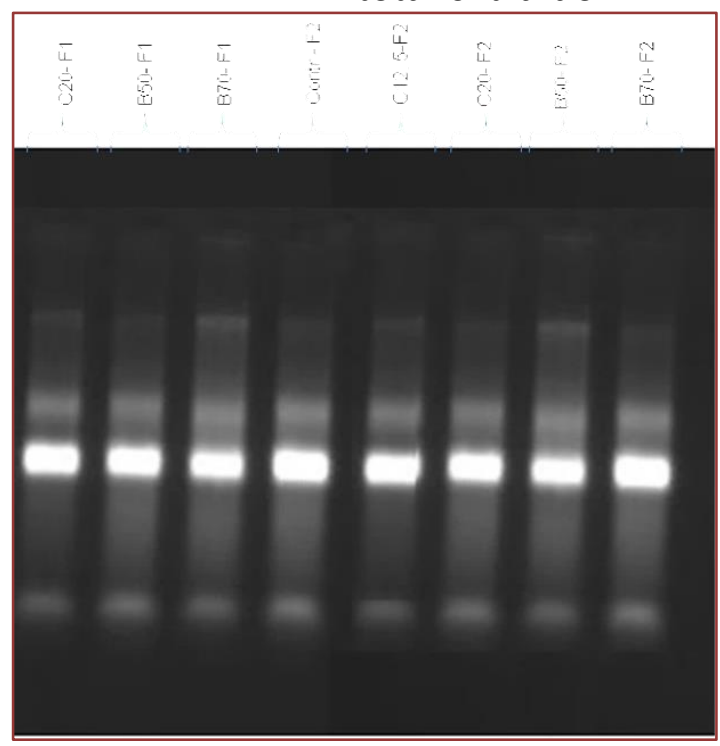

Os cDNAs sintetizados a partir do RNA total foram sintetizados com o oligo dT, os fragmentos da primeira fita de cDNA ou RNA mensageiros obtidos são de pequeno tamanho, menos que $100 \mathrm{pb}$. Na figura 5 é possível ver a qualidade da síntese dos cDNAs de Ae. albopictus, como um rastro (smear) de cDNA, obtidos a partir do RNA total extraído e tratado com DNase, observado em gel de agarose a 1\%.

Figura 13. Representação do cDNA em gel de agarose a 1\%. As colunas indicam as bandas (arraste) das fitas de cDNA de larvas de 3ํㅜㄹódio de Ae. albopictus submetidos ao EED e EBD por duas gerações.

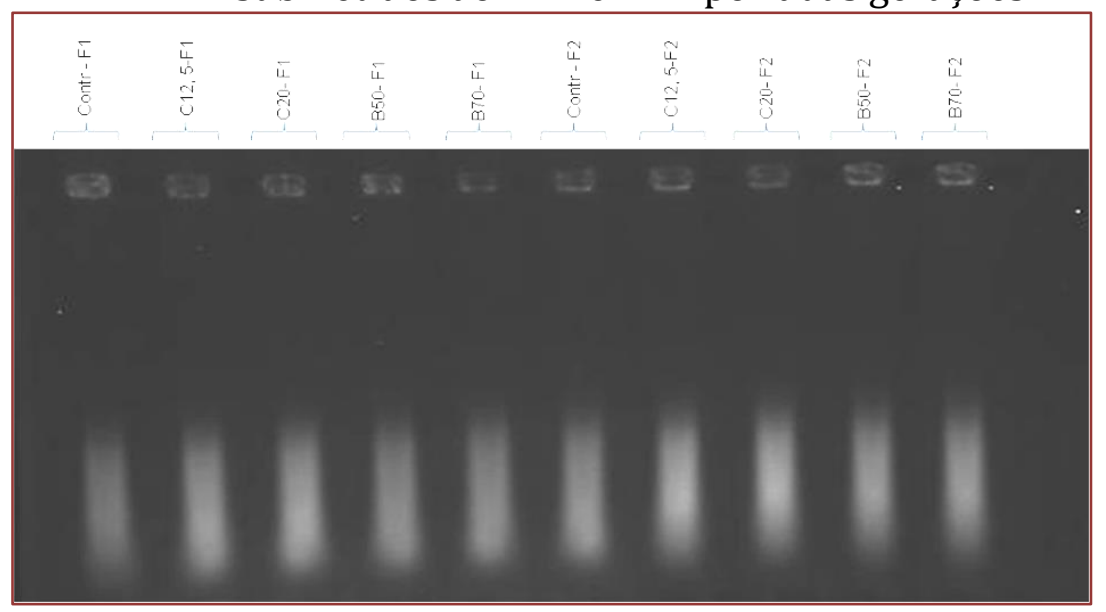

Foi realizado a validação do primer GSTe2 (heterólogo de 118 pb de Ae. aegypti), um gene de resistência a inseticida, que anelou na temperatura de $59.5{ }^{\circ} \mathrm{C}$, por meio da PCR clássica, em amostras do banco de cDNA de Ae. albopictus (gerações F1 e F2), previamente submetidas ao EED e EBD (Figura 6). 
Figura 14. Eletroforese dos produtos de PCR do par de primers da GSTe2 de Ae. aegypti no cDNA de Ae. albopictus em gel de agarose a 1\%. M1= Marcador 1KB plus Leader de 1000 pares de base $(\mathrm{pb})$.

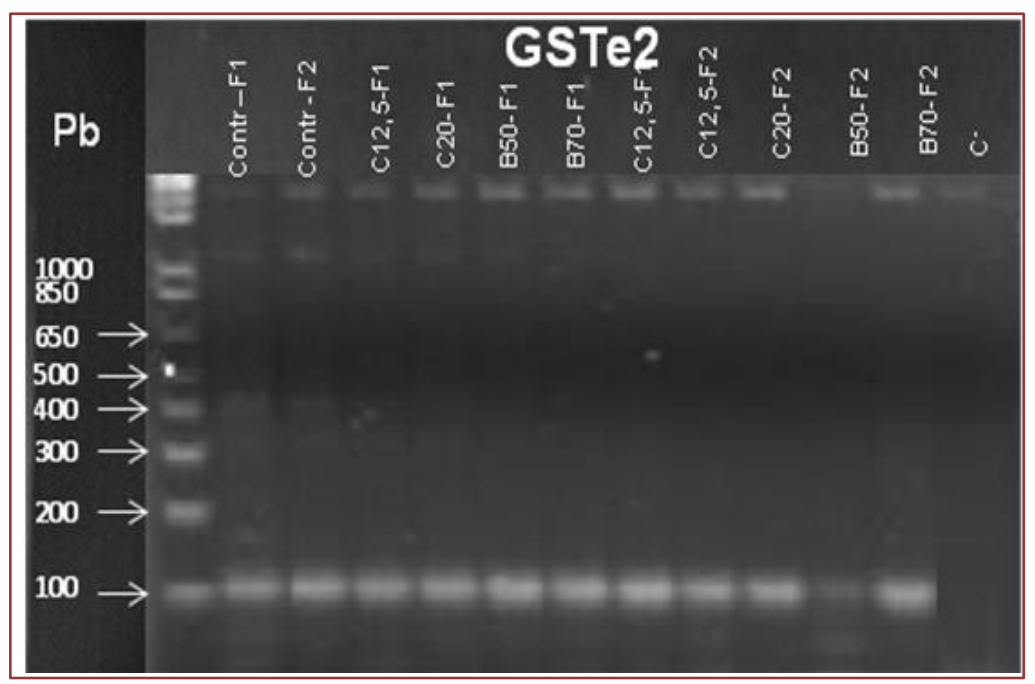

A aplicação mais comum de bibliotecas de cDNA é a identificação de genes de interesse e a quantificação de genes associados a mudanças estruturais e funcionais de alta relevância, para controles de doenças ou de moléculas específicas (YING, 2004). No controle populacional de vetores envolvidos no processo de resistência a compostos xenobióticos, a expressão diferencial de diversos genes tem sido uma ferramenta muito útil (HEMINGWAY et al., 2004).

O emprego dessa técnica em estudos moleculares tem permitido avanços na compreensão da dinâmica de resistência a pesticidas e seus mecanismos associados em populações de Aedes (STRODE et al., 2012). Em Ae. albopictus oriundos da Malásia, foi observado a super expressão dos genes CYP6P12 fortemente associada à resistência a piretróides e, CYP6N3 ao carbamato e DDT (ISHAK et al., 2016). No Brasil, as populações de vetores da dengue têm sido submetidas a pressões de seleção por diferentes classes de inseticidas. Valle et al. (2019) mostraram o caráter multifatorial da resistência de Ae. aegypti baseado nos dados disponíveis entre 1985 e 2017 de resistência contra os principais compostos inseticidas usados em nível nacional, incluindo o larvicida temefós e o adulticida deltametrina.

Rodriguez et al. (2012), utilizando os métodos de microarray e qPCR, demonstraram que cinco genes (GSTs) de resistência a permetrina foram expressos em populações de Ae. aegypti. Já Lumjuan et al. (2005), identificaram oito genes GST em Ae. aegypti resistentes aos inseticidas DDT e permetrina. A atividade precisa dessas enzimas de desintoxicação de inseticidas em Ae. albopictus ainda precisam ser investigadas.

Dados de resistência de biocompostos sobre populações de Ae. albopictus são escassas. No entanto, populações de Ae. aegypti tratadas com o derivado do dilapiol Isodilapiol, em diferentes concentrações ao longo de quatro gerações, apresentaram mortalidade de larvas em bioensaios, durante 4 horas e níveis de expressão elevados dos genes GSTE7 e P450-12. Esses dados mostraram que o composto Isodilapiol pode ter desencadeado estresse oxidativo e mortalidade dessas larvas de Ae. aegypti, revelandose um composto de potencial efeito no controle de Ae. aegypti, vetor da dengue (LIMA, 2015). 


\section{CONCLUSÃO}

A construção da biblioteca de cDNA (cópia filamentar do RNA mensagem) foi amplificada com bom rendimento e qualidade, utilizando-se o par de primer do gene da Glutationa S-Tranferase (GSTe2), por meio do método da PCR clássica. Estes resultados permitirão a realização da quantificação dos níveis de expressão de genes de resistência a inseticidas de interesse em Ae. albopictus, como um potencial alternativo, ao controle desse mosquito, pois ainda não há registros de resistência a esse biocomposto e nem de danos deste ao meio ambiente.

\section{AGRADECIMENTOS}

Agradecemos à Coordenação de Apoio à Formação de Pessoal de Nível Superior (CAPES), Conselho Nacional de Desenvolvimento Científico e Tecnológico (CNPq) pela bolsa de fomento, ao Projeto número 465540 / 2014-7 (CNPq), Coordenador Dr. Adalberto Luis Val e FAPEAM / SEPLANCTI / Governo do Estado do Amazonas, POSGRAD, projeto número 002/2016.

\section{REFERÊNCIAS}

BEATY, B. J.; MARQUARDT, W. C. The biology of diseases vectors. University Press of Colorado. 1996.

BELZILE, A. S.; MAJERUS, S. L.; PODESZFINSKI, C.; GUILLET, G.; DURST, T.; ARNASON, J. T. Dilapiol Derivatives as Synergists: Structure-Activity Relationship Analysis. Pestic Biochem Phys. 66: 33-40. 2000.

BERNARD, C. B.; KRISHINAMURTY, H. G.; CHAURET, D.; DURST, T.; PHILOGENE, B. J. R.; SANCHÉS - VINDAS, P. C.; HASBAUN, L.; POVEDA, L. S.; ROMAN AND ARNASON, J.T. Insecticidal defenses of Piperaceae from the neotropics. J Chem Ecol 21: 801-814. 1995.

BRAGA, I.A.; VALE, D. Aedes aegypti: inseticidas, mecanismo de ação e resistência. Epidemiologia e Serviços de Saúde, Brasília.16 (4): 279-293. 2007.

BROGDON, W. G.; MCALLISTER, J. C. Insecticide resistance and vector control. Emerg Infect Dis. 4 (4): 605-613. 1998.

CONSOLI, R. A. G. B.; OLIVEIRA, R. L. Mosquitos de importância sanitária do Brasil. Rio de Janeiro: Fiocruz. 228p. 1994.

DOMINGOS, P. R. C.; PINTO, A. C. S.; SANTOS J. M. M.; RAFAEL, M. S. Insecticidal and genotoxic potential of two semi-synthetic derivatives of dillapiole for the control of Aedes (Stegomyia) aegypti (Diptera: Culicidae). Mutat Res Genet Toxicol Environ Mutagen. 772: 42-54. 2014.

FERRARI, J. A. Insecticide resistance In: The Biology of Disease Vectors. Colorado: University Press of Colorado. 1996.

FORATTINI, O. P. Culicinae: Aedini in Culicidologia Médica. São Paulo: editora da Universidade de São Paulo.2: 403-484. 2002. 
FORATTINI, 0. P. Identificação de Aedes (Stegomyia) albopictus (Skuse) no Brasil. Rev Saúde Pública. 20: 244-5. 1986.

GOMES, A. C.; BITTENCOURT, M. D.; NATAL, D.; PINTO, P. L. S.; MUCCI, L. F.; PAULA, M. B.; URBINATTI, P. B.; BARATA, J. M. S. Aedes albopictus em área rural do Brasil e implicações na transmissão de febre amarela silvestre. Rev Saúde Pública. 33: 95-7. 1999.

GUZMÁN, M. G.; KOURÍ, G. 2001. Dengue: an update. Lancet Infecti Dis. 2: 33-42.

HEMINGWAY, J. The molecular basis of two contrasting metabolic mechanisms of insecticide resistance. Ins Biochem Molr Biol, Oxford. 30 (11): 1009-1015. 2000.

HEMINGWAY, J.; HAWKES, N. J.; MCCARROL, L.; RANSON, H. Mini Review: The molecular basis of insecticide resistance in mosquitoes. Ins Biochem Mol Biol, Oxford. 34 (7): 653 665. 2004.

ISHAK, I. H.; RIVERON, J. M.; IBRAHIM, S. S.; STOTT, R.; LONGBOTTOM, J.; IRVING, H.; WONDJI, C. S. The Cytochrome P450 gene CYP6P12 confers pyrethroid resistance in kdrfree Malaysian populations of the dengue vector Aedes albopictus. Scient Reports. 6:24707. 2016.

KUHN, R.J.; ZHANG, W.; ROSSMANN, M.G.; PLETNEV, S.V.; CORVER, J.; LENCHES, E.; JONES, C.T.; MUKHOPADHYAY, S.; CHIPMAN, P.R.; STRAUSS, E. G.; BAKER, T.S.; STRAUSS, J.H. 2002. Structure of Dengue Virus: Implications for Flavivirus Organization, Maturation, and Fusion. Cell. 108: 717-725.

LIMA, V. S.; PINTO, A. C.; RAFAEL, M. S. Effect of isodillapiole on the expression of the insecticide resistance genes GSTE7 and CYP6N12 in Aedes aegypti from central Amazonia. Genet Mol Res. 14(4): 16728-35. 2015.

LUMJUAN, N.; MCCARROLL, L.; PRAPANTHADARA, L. A.; HEMINGWAY AND RANSON, H. Elevated activity of an Epsilon class glutathione transferase confers DDT resistance in the dengue vector, Aedes aegypti. Ins Biochem Mol Biol 35: 861 - 871. 2005.

MEIRELES, S.F.; DOMINGOS, P.R.C.; PINTO, A.C.S.; RAFAEL, M.S. Toxic effect and genotoxicity of the semisynthetic derivatives dillapiole ethyl ether and dillapiole n-butyl ether for control of Aedes albopictus (Diptera: Culicidae). Mutat Res. 807: 1-7. 2016.

OPPENOORTH, F. J. Biochemical and genetic in insecticide resistance. In: Kerkut GA, Gilbert LI, editors. Comprehensive Ins Phys Biochemi Pharmac.12:731-773. 1985.

PARK, B. S.; LEE, S. E.; CHOI, W. S.; JEONG, C. Y.; SONG, C. AND CHO, K. Y. Insecticidal and acaricidal activity of pipernonaline and piperoctadecalidine derived from dried fruits of Piper longum L. Crop Prot. 21: 249 - 251. 2002.

PAUPY, C.; DELATTE, H.; BAGNY, L.; CORBEL, V.; FONTENILLE, D. Aedes albopictus, an arbovirus vector: from the darkness to the light. Microbes and Infect. Paris, 11(14-15): 1177-1185. 2009. 
PRAPANTHADARA, L.; KOOTTATHEP, S.; PROMTET, N. Purification and characterization of a major glutathione-S-transferase from the mosquito Anopheles dirus. Ins Biochem Mol Biol. 26: 277-285. 1996.

PINTO, A. C. S. Desenvolvimento de substâncias semi-sintéticas e bioativas a partir de 4nerolidilcatechol e dilapiol. Tese de Doutorado. Biotecnologia, área de Saúde, Universidade Federal do Amazonas. 296 p. 2008.

PINTO, A.C.S.; NOGUEIRA, K.L.; CHAVES, F.C.M.; SILVA, L.V.S.; TADEI, W.P.; POHLIT, A.M. Adulticidal Activity of Dillapiol and Semi-synthetic Derivatives of Dillapiol against Aedes aegypti (L.) (Culicidae). J Mosq Res. 2: 1-7. 2012.

RAFAEL, M. S.; HEREIRA-ROJAS, W. J.; ROPER, J. J.; NUNOMURA, S. M.; TADEI, W. P. Potential control of Aedes aegypti (Diptera: Culicidae) with Piper aduncum L. (Piperaceae) extracts demonstrated by chromosomal biomarkers and toxic effects on interphase nuclei. Genet Mol Res. 7(3): 772-781. 2008.

RANSON, H. Evolution of supergene families associated with insecticide resistance. Sci, Washington. 298 (5591): 179 - 181.2002.

RITTER, L. Report of a panel on the relationship between public exposure to pesticides and cancer. Cancer. 80: 2019. 1997.

RUSSELL, T. L. Increased proportions of outdoor feeding among residual malaria vector populations following increased use of insecticide-treated nets in rural Tanzania. Malar J, London. 10: 80. 2011.

SANTOS, L. H. F.; DOMINGOS, P. R. C.; MEIRELES, S. F.; BRIDI, L. C.; PINTO, A. C. S.; RAFAEL, M. S. Genotoxic effects of semi-synthetic isodillapiole on oviposition in Aedes aegypti (Linnaeus, 1972) (Diptera: Culicidae). Rev Soc Bras Med Trop. 53. 2020.

SENGUPTA, S. AND RAY, A. B. The chemistry of Piper species: A review. Fitoterapia 58: 147-166. 1987.

SILVA, H. H.; SILVA, G.; LIRA, I. G. Metodologia de criação, manutenção de adultos e estocagem de ovos de Aedes aegypti (Linnaeus, 1762) em laboratório. Rev Pat Trop. 27: $53-63.1998$.

SILVA, H. H. G.; SILVA, I. G.; SANTOS, R. M. G.; FILHO, E. R.; ELIAS, C. N. Atividade larvicida de taninos isolados de Magonia pubescens St. Hil. (Sapindaceae) sobre Aedes aegypti (Diptera, Culicidae). Rev Soc Bras Med Trop. 37: 396 - 399. 2004.

STRODE, C. Genomic analysis of detoxification genes in the mosquito Aedes aegypti. Ins Biochem Mol Bio, Oxford. 38 (1): 113-123. 2008.

STRODE, C.; DE MELO-SANTOS, M.; MAGALHÃES, T.; ARAÚJO, A.; AYRES, C. Expression Profile of Genes during Resistance Reversal in a Temephos Selected Strain of the Dengue Vector, Aedes aegypti. PLoS ONE 7(8): e39439. 2012.

TANG, A. H.; TU, C. P. Biochemical caracterization of Drosophila glutathione Stransferase D1 and D2. J Biol Chem. 269: 27876-27884. 1994. 
VALLE, D.; BELLINATO, D. F.; VIANA-MEDEIROS, P. F.; LIMA, J. B. P.; MARTINS-JUNIOR, A. D. J. Resistance to temephos and deltamethrin in Aedes aegypti from Brazil between 1985 and 2017. Mem Inst Oswaldo Cruz. 114 (3): e180544. 2019.

VÉLEZ ID, QUIÑONES ML, SUÁREZ MO, OLINO L, MÚRCIA LM, CORREA E, [ET AL.] AREVELO C, PÉREZ L, BROCHERO H, MORALE A. Presença de Aedes albopictus em Letícia Amazonas, Colombia Biomédica. 18(3): 192-8. 1998.

VONTAS, J. G.; SMALL, G. J.; NIKOU, D. C.; RANSON, H.; HEMINGWAY, J. Purification, molecular cloning and heterologous expression of a glutathione S-transferase involved in insecticide resistance from the rice brown planthopper, Nilaparvata lugens. Biochem. J. 362: 329 - 337. 2002.

YANG, Y.; CHENG, J. Z.; SINGHAL, S. S.; SAINI, M.; PANDYA, U.; AWASTHI, S. Role of glutathione S-transferases in protection against lipid peroxidation. J Biol Chem. 276 (22): 19220-19230. 2001.

YING, S.Y. Complementary DNA Libraries: An Overview. Mol Biotech 27: 245-252. 2004.

WHO - World Health Organization. Dengue transmission research in WHO Bulletin. TDR: For research on diseases of poverty. Geneva, Switzerland. 2010. Disponível em: http://apps.who.int/tdr/svc/news-events/news/dengue-transmission. 2010.

WHO - World Health Organization. WHOPES - recommended compounds and formulations for control of mosquito larvae. 2017. Disponível em: http://www.who.int/whopes/Mosquito_larvicides_28_July_2017.pdf. 


\section{Capítulo 21}

\section{Avaliação de dois métodos de extração de RNA total de Aedes aegypti Linnaeus, 1762 (Diptera: Dulicidae)}

\section{Joaquim Ferreira do Nascimento Neto}

Sabrina da Fonseca Meireles

Thamiles das Chagas Gonçalves

Miriam Silva Rafael

Rosemary Aparecida Roque

Wanderli Pedro Tadei

Resumo: A família Culicidae alberga mosquitos de grande importância para a saúde pública, pois estão envolvidos na transmissão de múltiplos agentes etiológicos. 0 Aedes aegypti é o principal vetor dos arbovírus dengue, Zika e chikungunya. Considerando as diferentes fases do ciclo de vida desse mosquito (ovo, larva, pupa e adulto) e sua potencialidade na transmissão de doenças, foi realizada a extração de RNA total de larvas e adultos de Ae. aegypti, utilizando o reagente TRIzolTM (Invitrogen ${ }^{\mathrm{TM}}$ ) e o kit RNeasy® Plant Mini (Quiagen®), a fim de avaliar a eficiência desses métodos. O RNA total de quatro amostras (pools de 20 larvas e adultos) foi extraído com sucesso. Os dois métodos apresentaram eficácia, obtendo-se mais de 500 ng em cada extração de RNA total com absorbâncias 260/280 (>2) e 260/230 (>1). Desse modo, o reagente TRIzol mostrou-se mais acessível. Estes resultados são importantes, pois a obtenção de RNA com alta concentração, boa qualidade, puro e íntegro, é essencial para a realização de análises moleculares de alta sensibilidade.

Palavras-chave: Arbovírus, cDNA, Dengue, Inseto, qPCR. 


\section{INTRODUÇÃO}

Os mosquitos pertencentes à família Culicidae possuem grande importância para a saúde pública, pois estão envolvidos na transmissão de múltiplos agentes etiológicos (TERRA et al., 2017, FRITZELL et al., 2018). Dentre esses, o Aedes aegypti Linnaeus 1762 destaca-se por ser o principal transmissor dos vírus que causam dengue, febre amarela, chikungunya e Zika, responsáveis por elevados números de internações e óbitos (MARCONDES e XIMENES, 2015; OMS, 2021).

Um tema preocupante, é a relação das mudanças climáticas e o favorecimento da reprodução de insetos vetores de doenças, como o Ae. aegypti (WILKE et al., 2019; FERREIRA et al., 2020). Sabe-se que os países de clima tropical e subtropical de temperaturas naturalmente elevadas, propiciam condições favoráveis à reprodução e permanência do Ae. aegypti nesses ambientes, tornando as arboviroses mais frequentes (LIMA-CAMARA, 2016).

As mudanças climáticas podem influenciar significativamente na taxa de desenvolvimento e crescimento dessa espécie, desde as formas larvais até a longevidade dos adultos (MOHAMMED e CHADEE, 2011). A temperatura influencia diretamente o tempo de maturação das larvas e o $\mathrm{CO}_{2}$ na localização do mosquito ao seu hospedeiro (FORATTINI, 2002; SMITH et al., 2013). A capacidade de regular a expressão de genes essenciais para sua sobrevivência e reprodução podem estar relacionados ao sucesso de sobrevivência do Ae. aegypti a estes ambientes antrópicos (NASCIMENTO-NETO et al., 2020; SHARMA et al., 2020).

Análises moleculares, como investigação dos padrões de expressão gênica, podem fornecer indícios importantes para entender os mecanismos por trás do comportamento da população. A eficácia dos estudos depende da metodologia aplicada. A análise de RNA é capaz de fornecer informações de expressão gênica relevantes, que podem ser utilizadas para diferentes objetivos. Porém, é necessário que os métodos de extração gerem produtos de boa qualidade e em quantidades adequadas (DETTOGNI e LOURO, 2017).

Diferentes metodologias de extração de RNA, específicas para cada tipo de amostra estão disponíveis na literatura. Em todos os métodos as etapas básicas de: (1) lise e desnaturação das células; (2) purificação do RNA e; (3) precipitação, são as mesmas (BASTOS et al., 2016; DETTOGNI e LOURO, 2017). Considerando as diferentes fases do ciclo de vida do Ae. aegypti (ovo, larva, pupa e adulto) e sua potencialidade na transmissão de doenças, propôs-se a avaliação de dois métodos distintos de extração de RNA total de larvas e adultos desse mosquito, a fim de obter RNA com alta concentração, boa qualidade de pureza, íntegro e menos oneroso, visando posteriores análises moleculares de alta sensibilidade.

\section{REFERÊNCIA TEÓRICO}

\subsection{DISTRIBUIÇÃO E BIOLOGIA DO Aedes aegypti}

O Ae. aegypti é nativo do continente africano, originalmente descrito no Egito (CHRISTOPHERS, 1960; BRAGA e VALLE, 2007). A propagação desse mosquito para outros continentes ocorreu durante as explorações europeias ao Novo Mundo, por meio de navios tumbeiros. Atualmente, ocorre nas regiões tropicais e subtropicais do mundo, onde o clima é favorável ao seu desenvolvimento (KRAEMER et al., 2015). 
No Brasil, há registros desse mosquito desde o final do século XIX, mas devido ao intenso combate à febre amarela urbana no país foi considerado erradicado em 1955 . No entanto, diversos fatores contribuíram para a reintrodução desse vetor a partir de países adjacentes: como o aumento populacional na década de 70; o crescimento desordenado das cidades e; falhas na vigilância epidemiológica, o que favoreceu sua distribuição para todos os estados e Distrito Federal (BRAGA e VALLE 2007; CARVALHO e MOREIRA, 2017; TERRA et al., 2017).

O ciclo de vida do Ae. aegypti é do tipo holometábolo, ou seja, compreende os estágios de ovo, larva, pupa e adulto, podendo durar de sete a 14 dias, dependendo da quantidade de alimento disponível e temperatura (FORATTINI, 2002, CARVALHO e MOREIRA, 2017). As fêmeas possuem preferência por ovipor em criadouros naturais ou artificiais úmidos com parede rugosa, normalmente dois milímetros acima do menisco da água (FORATTINI, 1995; FORATTINI et al., 1997, CONSOLI e OLIVEIRA, 1998). Em média, as fêmeas de Ae. aegypti podem ovipor entre 80 a 120 ovos por postura e podem viver em média 45 dias (MARQUES et al., 2013; AMARAL et al., 2020).

O Ae. aegypti tem ciclo de atividade diurno, com picos no amanhecer e crepúsculo, podendo o tempo de atividade de busca da espécie ser alterado em função das condições ambientais as quais está inserido (SMITH et al., 2013, RODRIGUES et al., 2018). Os machos e as fêmeas do mosquito se alimentam de seiva de plantas e soluções açucaradas no ambiente natural; enquanto as fêmeas se alimentam de sangue de vertebrados, para a maturação dos ovos (FORATTINI 2002; FARJANA e TUNO, 2013).

\subsection{EPIDEMIOLOGIA E CONTROLE}

No Brasil, em 2020, ocorreram 987.173 casos prováveis de dengue, conforme os boletins epidemiológicos do Ministério da Saúde. Com relação à chikungunya, foram notificados 82.419 casos e 7.387 de Zika (figura 1). No primeiro mês de 2021, foram registrados 22.332 casos de dengue, 1.459 de chikungunya e 58 de Zika (OMS, 2021).

Figura 1. Identificação de sorotipos DENV (A), CHIKV (B) e ZIKV (C), por unidade federada.

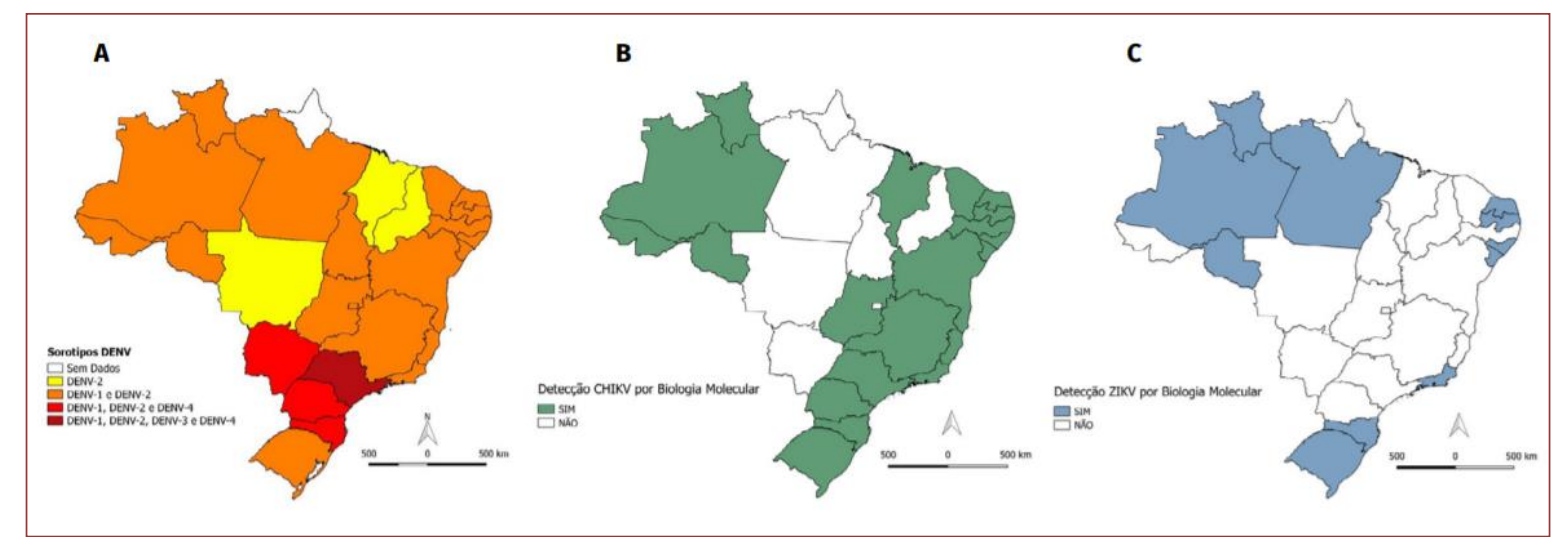

Fonte: Coordenação-Geral de Laboratórios de Saúde Pública (CGLAB). Dados atualizados em 14/12/2020.

A principal estratégia para reduzir os casos de doenças é a partir do controle vetorial em diferentes fases do seu ciclo de vida. A aplicação de inseticidas químicos é o método mais aplicado há muitos anos em diferentes países. Entretanto, apesar de eficientes, muitas consequências negativas foram provocadas pela elevada e contínua 
utilização desses produtos, como a contaminação ambiental, a eliminação de espécies não-alvo, o acúmulo na cadeia alimentar e a seleção da resistência nos mosquitos (NASCIMENTO e MELNYK, 2016; CARVALHO e MOREIRA, 2017; OLIVEIRA et al., 2017; SOUZA et al., 2017).

Uma alternativa a esse método é o controle biológico, como algumas espécies de peixes e outros invertebrados aquáticos que se alimentam de larvas e pupas; além de extratos botânicos e patógenos, como fungos e bactérias que liberam substâncias tóxicas para os mosquitos (BENELLI et al., 2016; ZARA et al., 2016; CARVALHO e MOREIRA, 2017). Outra abordagem, é o controle mecânico - eliminação dos criadouros, além de ações educativas voltadas à população, geralmente empregadas por programas do governo para conter a proliferação do Ae aegypti (ZARA et al., 2016; CARVALHO e MOREIRA, 2017)

\section{MATERIAL E MÉTODOS}

\subsection{COLÔNIA DE Aedes aegypti}

As amostras de Ae. aegypti foram obtidas a partir de colônia pré-estabelecida no laboratório de Malária e Dengue (LMD) do INPA, oriundas de coletas realizadas em seis zonas da cidade de Manaus-AM, por meio de armadilhas de oviposição (ovitrampas) com palhetas de Duratree ${ }^{\circledR}$, embebidas em recipiente de plástico escuro com água sem cloro (FAY e ELIASON, 1966). Em insetário, as larvas foram alimentadas com ração para ratos e roedores na proporção 1:1; as pupas foram transferidas para copo de plástico de 50 $\mathrm{mL}$ e inseridas dentro de gaiolas teladas para emergência dos adultos; os machos e fêmeas foram alimentados com solução açucarada; e o repasto sanguíneo para as fêmeas foi realizado em Hamster Mesocricetus auratus anestesiados por $30 \mathrm{~min}$ (CEUA/INPA 033/2018).

\subsection{PREPARO DOS GRUPOS AMOSTRAIS}

A partir da colônia estabelecia em insetário, 25 larvas de $3^{\circ}$ estádio e 25 adultos foram armazenados em microtubos de $2 \mathrm{~mL}$, sem resíduo de água em três réplicas biológicas para os dois testes. Os microtubos contendo larvas e adultos foram imediatamente congelados a $80{ }^{\circ} \mathrm{C}$ negativos em nitrogênio líquido $\left(\mathrm{N}_{2}\right)$, para evitar variações na expressão gênica que, eventualmente, o estresse da coleta poderia provocar às amostras (GONÇALVES, 2019, NASCIMENTO NETO et al., 2020).

Após o congelamento, as amostras para teste com TRIzol ${ }^{\mathrm{TM}}$ (Invitrogen) foram processadas da seguinte forma: larvas e adultos foram transferidos com auxílio de uma pinça para microtubos de $2 \mathrm{~mL}$ contendo $1 \mathrm{~mL}$ e $500 \mu \mathrm{L}$ do reagente, respectivamente; as amostras foram homogeneizadas por sucção com movimentos up-down, com ponteiras de $1 \mathrm{~mL}$ com filtro, livres de RNAse; após homogenizados, os microtubos foram armazenados em ultracongelador a $80{ }^{\circ} \mathrm{C}$ negativos até a etapa de extração do RNA (WANG et al., 2011, da COSTA et al., 2017). 


\subsection{EXTRAÇÃO DE RNA TOTAL COM O REAGENTE}

O RNA total foi extraído utilizando o reagente TRIzolTM (Invitrogen $^{\mathrm{TM}}$ ), seguindo as recomendações do fabricante em cabine de segurança previamente preparada, com consumíveis livres de RNAse (NASCIMENTO NETO et al., 2020). Em temperatura ambiente foi adicionado 0.1 e $0.2 \mathrm{~mL}$ de clorofórmio Merk® gelado nas amostras de larvas e adultos, respectivamente. Os tubos foram homogeneizados em vórtex com pulsos de 2 a 4 segundos, seguido de repouso por 2 minutos à temperatura ambiente e centrifugação a $12.000 \mathrm{~g}$ por 15 min. a $4{ }^{\circ} \mathrm{C}$. Após centrifugação, foram observadas três fases no microtubo, saber: (1) no fundo do tubo, o lisado de tecido contendo o TRIzol em vermelho; (2) uma interfase branca com aspecto de nuvem; (3) na fase superior, uma fase aquosa transparente. Esta última (sobrenadante), foi transferida cuidadosamente para um novo microtubo.

Foi adicionado sobre o sobrenadante das amostras de larvas e adultos, $500 \mu \mathrm{L}$ e 1 mL de álcool isopropílico Merk® gelado, respectivamente, seguido de homogeneização, suavemente com as mãos. Os microtubos foram incubados em gelo por 10 minutos e centrifugados a $12.000 \mathrm{~g}$ por 10 minutos a $4{ }^{\circ} \mathrm{C}$. 0 sobrenadante foi removido, preservando o pellet formado no fundo do tubo, que foi ressuspenso com $1 \mathrm{~mL}$ de etanol $75 \%$ gelado, seguido de vórtex e centrifugação a $7.500 \mathrm{~g}$ por 5 minutos a $4{ }^{\circ} \mathrm{C}$. Cerca de $200 \mu \mathrm{L}$ de sobrenadante foi retirado e os tubos foram acomodados abertos em uma raque apropriada, cobrindo-os com papel alumínio por até 2 minutos, para evaporação do etanol residual em temperatura ambiente, evitando secar completamente o pellet. Após a secagem, o pellet foi ressuspenso em $30 \mu \mathrm{L}$ de água RNAse-free, agitando brevemente com as mãos para a hidratar o pellet de RNA.

\subsection{EXTRAÇÃO DE RNA TOTAL COM O KIT RNeasy® Plant Mini (QUIAGEN®)}

A extração de RNA total, com o kit RNeasy® Plant Mini (Quiagen®) cat. № 74904 adaptado para Ae. aegypti, seguiu as instruções do fabricante. Na primeira etapa, os microtubos contendo 25 larvas e 25 adultos foram macerados em $450 \mu \mathrm{L}$ de tampão RLT ou Buffer RLC, dentro de isopor com nitrogênio líquido. 0 material lisado foi transferido para a coluna spin QIAshredder acoplada ao microtubo de $2 \mathrm{~mL}$ e centrifugado por $2 \mathrm{~min}$. na velocidade máxima. 0 sobrenadante foi transferido para novo microtubo e adicionado 0,5 volume de etanol (96-100\%), misturado por pipetagem. A amostra foi transferida para uma coluna de spin RNeasy, colocada em outro tubo de coleta de $2 \mathrm{~mL}$, seguido de centrifugação por 15 segundos a ( $\geq 10.000 \mathrm{rpm})$.

Foi adicionado $700 \mu \mathrm{L}$ de tampão RW1 (fornecido pelo fabricante) à coluna spin RNeasy, seguido de centrifugação por $15 \mathrm{~s}$ a $(\geq 10.000 \mathrm{rpm})$ e descarte do material escoado. Essa lavagem foi repetida na mesma coluna, com adição de $500 \mu \mathrm{L}$ de tampão RPE, em um novo tubo de coleta de $1,5 \mathrm{~mL}$. Foi adicionado na coluna spin RNeasy $30 \mu \mathrm{L}$ de água livre de DNA diretamente à membrana dessa coluna, que foi centrifugada por 1 minuto $(\geq 10.000 \mathrm{rpm})$. 0 microtubo contendo o RNA total foi estocado em $80{ }^{\circ} \mathrm{C}$ negativos. 


\subsection{QUANTIFICAÇÃO E TRATAMENTO COM DNase}

A quantificação prévia e pureza da extração do RNA foi realizada no equipamento NanoDrop 2000c (Thermo Scientific ${ }^{\mathrm{TM}}$ ) nos comprimentos de onda 260/280 e 260/230. A integridade do RNA foi verificada em 1\% gel de agarose, corado com brometo de etídio $5 \mu \mathrm{g} / \mathrm{ml}$, em tampão TBD diluído em água tratada com DEPC. Todas as amostras de RNA total para a construção de bibliotecas de cDNA foram tratadas com DNase I (Invitrogen ${ }^{\mathrm{TM}}$ by Thermo) seguindo as recomendações do fabricante. Após tratadas, o RNA total foi quantificado utilizando Qubit 2.0 com o químico RNA BR Assay Kit (Invitrogen ${ }^{\mathrm{TM}}$ ) e diluído para a concentração de $1000 \mathrm{ng} / \mu \mathrm{L}$.

\subsection{SÍNTESE DE cDNA}

Na construção das bibliotecas de cDNA, foi utilizado o kit de transcrição HighCapacity cDNA Reverse (Applied Biosystems ${ }^{\mathrm{TM}}$ ), seguindo as recomendações do fabricante, com concentração final de RNA total a $100 \mathrm{ng} / \mu \mathrm{L}$.

\subsection{VALIDAÇÃO DO cDNA}

Após a síntese de cDNA, foi utilizado o kit GoTaq ${ }^{\circledR}$ DNA Polymerase (Promega) para a amplificação do gene endógenos actin. Em volume final de $10 \mu \mathrm{L}$, o mix consistia em $2 \mu \mathrm{L}$ de tampão 5X; 0,8 $\mu \mathrm{L}$ de $\operatorname{MgCl}_{2}(2 \mathrm{mM}) ; 0,2 \mu \mathrm{L}$ de dNTP $(0,2 \mathrm{mM}) ; 0,2 \mu \mathrm{L}$ de primer foward $(2 \mathrm{mM}) ; 0,2 \mu \mathrm{L}$ de primer reverse $(2 \mathrm{mM}) ; 0,05 \mu \mathrm{L}$ de Taq DNA Polimerase $(0,25 \mathrm{U} / \mu \mathrm{L})$ e $1 \mu \mathrm{L}$ de cDNA $(100 \mathrm{ng} / \mu \mathrm{L})$. Os genes foram amplificados em um termociclador Swift ${ }^{\mathrm{TM}}$, seguindo os parâmetros de ciclagem: pré-corrida a $95{ }^{\circ} \mathrm{C}$ por 3 min., 40 ciclos de $95{ }^{\circ} \mathrm{C}$ por 15 seg., pareamento a $60{ }^{\circ} \mathrm{C}$ por 30 seg., extensão a $72{ }^{\circ} \mathrm{C}$ por 30 seg., pós-corrida de $72{ }^{\circ} \mathrm{C}$ por $3 \mathrm{~min}$. (GONÇALVES, 2019, NASCIMENTO NETO et al., 2020).

Após amplificação, o produto de PCR passou por eletroforese preparado com tampão TBD tratado com DEPEC, em gel de agarose a 2\%, corado com brometo de etídio $5 \mu \mathrm{g} / \mathrm{mL}$. A eletroforese foi visualizada e quantificada em transiluminador Benchtop $U V$.

\section{RESULTADOS E DISCUSSÃO}

\subsection{EXTRAÇÃO DE RNA TOTAL COM O REAGENTE TRIzol}

Foram observados durante a condução dos experimentos de extração de RNA total de larvas e adultos de Ae. aegypti com o reagente TRIzol, padrões distintos para as amostras extraídas a partir de larvas e adultos. Na extração das amostras de larvas, observou-se que o produto homogeneizado teve um aspecto de cor creme e limpo, enquanto o mix formado a partir do adulto total teve um aspecto mais escuro e opaco. Ao final do processo de extração e ressuspensão do pellet, as amostras de larvas tiveram um aspecto mais transparente, enquanto as amostras de adultos permaneceram com a cor próximo ao cinza-avermelhado. 
Tabela 01. Quantificação relativa e pureza de RNA avaliada em espectofotômetro NanoDrop 2000c.

\begin{tabular}{|c|c|c|c|}
\hline Amostra & Concentração ng/uL & $\mathbf{A}_{260 / 280}$ & $\mathbf{A}_{260 / 230}$ \\
\hline Larva & 2138,6 & 1,97 & 2,15 \\
\hline Adulto & $3.117,3$ & 2.03 & 1.33 \\
\hline
\end{tabular}

As relações de pureza entre larva e adulto em 260/280 se mantiveram satisfatórias, entretanto em 260/230 foram distintas. A integridade do produto de extração no gel de agarose ficou dentro dos padrões esperados, com bandas uniformes e integras em ambas as amostras (figura 2). Apesar das relações de pureza entre as amostras no comprimento de onda 260/230 não apresentarem relação, a intensidade de banda entre as amostras amplificadas foi semelhante, não afetando, aparentemente, de forma significativa a reação de PCR.

Figura 02. (A) Extração do RNA de Aedes aegypti através do método de extração orgânica usando reagente TRIzoltm. (B) Produto de PCR oriundo da amplificação do gene actin a partir de cDNA. Foram aplicados 3uL de RNA total e produto de PCR em gel de agarose a $1 \%$, corado com brometo de etídio $5 \mu \mathrm{g} / \mathrm{mL}$.

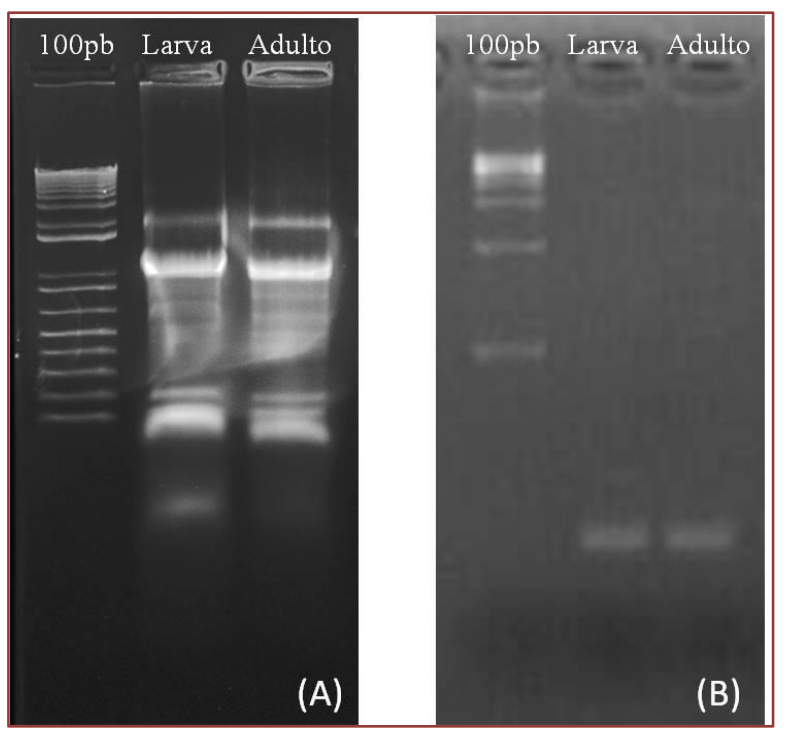

\subsection{EXTRAÇÃO DE RNA TOTAL COM O KIT RNeasy® Plant Mini}

A extração do RNA total de larvas e adultos de Ae. aegypti o kit RNeasy® Plant Mini, foi realizada com sucesso. Nas duas extrações foram obtidos mais de $500 \mathrm{ng}$ de RNA total, com absorbâncias consideradas ideais $>1<2$ de acordo com o quadro abaixo.

Tabela 02. Quantificação relativa e pureza de RNA avaliada em espectofotômetro NanoDrop 2000c.

\begin{tabular}{|l|c|c|c|}
\hline \multicolumn{1}{|c|}{ Amostra } & Concentração ng/uL & A 260/280 & A 260/230 \\
\hline Larva & $1.272,1$ & 1,99 & 1,83 \\
\hline Adulto & $1.161,9$ & 2.02 & 1.67 \\
\hline
\end{tabular}


A integridade do produto de extração no gel de agarose ficou dentro dos padrões esperados, com bandas uniformes e integras em ambas as amostras (figura 3).

Figura 03. (A) Extração do RNA total de Aedes aegypti como kit RNeasy® Plant Mini. (B)

Produto de PCR oriundo da amplificação do gene actin a partir de cDNA. Foram aplicados $3 \mathrm{uL}$ de RNA total e produto de PCR em gel de agarose a 1\%, corado com brometo de etídio $5 \mu \mathrm{g} / \mathrm{mL}$.

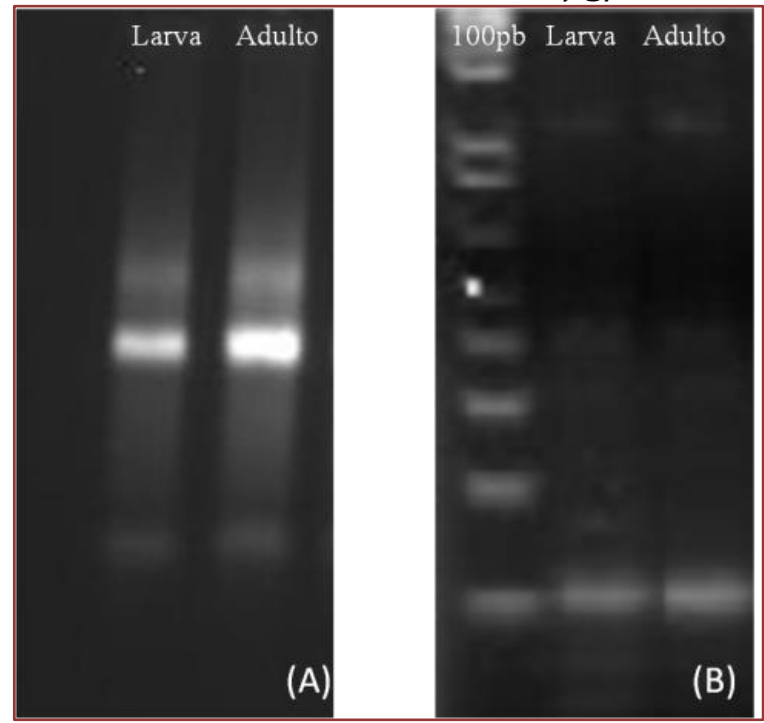

Atualmente, espécies vetoras de doenças tropicais são um dos grandes problemas na saúde pública, especialmente aquelas que apresentam facilidade de viver próximo ao homem como o Ae. aegypti (JORGE et al., 2019). Estudos moleculares, em especial os utilizando RNA, possibilitam a investigação de uma gama de aspectos sobre as respostas do mosquito a ambientes nos quais está inserido (SIM et al., 2007). Com isso, possibilita uma investigação rica em detalhes dos processos adaptativos e respostas do Ae. aegypti a determinada condição de estresse, ou a uma resposta fisiológica específica (POOLESMITH et al., 2015, WILL et al., 2017).

O uso da técnica de extração de RNA com TRIzol é amplamente empregado em diversos trabalhos na literatura (LUZ et al., 2016, NASCIMENTO NETO et al., 2020). Essa técnica, com amplo leque de aplicações e ajustes, depende do tipo de amostra que será extraído o RNA, seja para análises de expressão gênica em PCR em tempo real ou sequenciamento de nova geração (NGS) (BARBOSA, 2016). No entanto, por se tratar de uma técnica clássica, apresenta diversos requisitos que devem ser seguidos para possibilitar uma rotina (KÖHRER e DOMDEY 1991; GOUVEIA et al., 2011). Além do método clássico com TRIzol, a extração utilizando kits comerciais constituídos principalmente de coluna de sílica, garantem concentrações satisfatórias e alto grau de pureza, permitindo melhor reprodutividade (BARBOSA, 2016; PRASAD et al., 2017).

Apesar do método clássico de extração de RNA ser amplamente utilizado para extração de amostras frescas, ele não apresenta bom desempenho de extração para amostras armazenadas em condições com elevada quantidade de RNAses, inibidores ou métodos de preservação inadequados (GOUVEIA et al., 2011). Por apresentar extração eficiente para a obtenção de RNA viral, o método clássico ainda é usado como um dos métodos amplamente empregados para a detecção de vírus em amostras de campo e de laboratório com a finalidade de pesquisa (BONIZZONI et al., 2012). Os métodos utilizando kits comerciais também são amplamente utilizados em ensaios com objetivo 
de análise e pesquisa, entretanto é observado uma preferência maior aos métodos utilizando kit comercial para aplicações de diagnóstico (TOZATO, 2014; DA COSTA et al., 2017). Ambos os protocolos apresentam, a depender da aplicação, bons resultados se forem observados as suas principais aplicações e cuidados com o armazenamento, preparo de materiais e ambiente prévio para a extração.

Ao longo da extração de mosquitos adultos pelo método TRIzol foi observado que a fase formada após a adição do clorofórmio apresentou um aspecto mais escuro/cinza, enquanto o produto formado das larvas se manteve mais transparente. 0 aspecto mais escuro das amostras de adulto total possivelmente se deu em função da presença do exoesqueleto rico em quitina nos adultos, enquanto que as larvas não apresentam esse composto em grande quantidade no seu revestimento (BRAGA e VALLE, 2007). Nesse sentido, mais análises devem ser feitas para confirmar a presença de compostos residuais referentes ao exoesqueleto do mosquito no produto de extração de RNA com TRIzol.

Em resumo, o RNA, por ser uma molécula de fita simples, instável e de fácil degradação por ribonucleases (RNases) presentes em grande quantidade nos tecidos, requer cuidados específicos na coleta e no armazenamento das amostras (BITENCOURT et al., 2011, DETTOGNI e LOURO 2017). Os tampões utilizados devem conter água livre de RNases ou tratadas com dietilpirocarbonato (DEPEC), que atua inativando RNases presentes. As ponteiras e microtubos devem ser livres de RNases. A bancada e as micropipetas devem ser exclusivas para o trabalho com RNA e a manipulação, deve ser realizada com o auxílio de equipamentos de proteção individual, principalmente luvas, mantendo-as livre de RNAses (BASTOS et al., 2016).

\section{CONCLUSÃO}

Na extração de RNA, os cuidados na preparação das amostras desde a coleta até o armazenamento são fundamentais. Neste estudo, as duas metodologias utilizadas na extração de RNA total de larvas e adultos de Ae. aegypti mostraram-se eficazes, apresentando RNA com alta concentração, boa qualidade, puro e íntegro, essencial para a realização de análises moleculares de alta sensibilidade.

\section{AGRADECIMENTOS}

Agradecemos à Coordenação de Apoio à Formação de Pessoal de Nível Superior (CAPES), Conselho Nacional de Desenvolvimento Científico e Tecnológico (CNPq) pela bolsa de fomento e ao Projeto número 465540 / 2014-7 (CNPq), Coordenador Dr. Adalberto Luis Val.

\section{REFERÊNCIAS}

BARBOSA, P. P. Otimização da RT-PCR Multiplex para detecção de vírus dengue em amostras de Aedes aegypti infectados artificialmente. 2016.

BASTOS, C. R.; DESIDÉRIO, J. A., et al. V. Estudo da variabilidade genética aplicado à genômica animal. 2016.

BENELLI, G.; JEFFRIES, C.; WALKER, T. Biological Control of Mosquito Vectors: Past, 
Present, and Future. Insects 7: 52. 2016.

BITENCOURT, G. A.; CHIARI, L., et al. Avaliação de diferentes métodos para extração de RNA total de folhas e raízes de braquiária. Boletim de Pesquisa e Desenvolvimento 29: 22. 2011.

BONIZZONI, M.; DUNN, W. A., et al. Complex Modulation of the Aedes aegypti Transcriptome in Response to Dengue Virus Infection. PLoS ONE 7. 2012.

BRAGA, I. A.; VALLE, D. Aedes aegypti: inseticidas, mecanismos de ação e resistência. Epidemiologia e Serviços de Saúde. 16: 279-293. 2007.

CONSOLI, R. A. G. B.; OLIVEIRA, R. L. Principais Mosquitos de Importância Sanitária No Brasil. 1st ed. Fiocruz, Rio de Janeiro, 228p. 1998.

DA COSTA, C. F., et al. Transovarial transmission of DENV in Aedes aegypti in the Amazon basin: a local model of xenomonitoring. Parasites \& Vectors 10: 249. 2017.

COSTA, L. H. Avaliação de infoquímicos presentes em ovos e larvas de Aedes (Stegomyia) aegypti ( Linnaeus, 1762 ) ( Diptera: Culicidae ) como atraentes e / ou estimulantes de oviposição para grávidas co-específicas Laila Heringer Costa Avaliação de infoquímicos pr. : 129. 2010.

DETTOGNI, R. S.; LOURO, I. D. Desafios da extração do RNA do vírus da dengue. January. In: Biotecnologia Aplicada à Agro\&Indústria - Vol. 4, Editora Blucher, p.937-966. 2017.

[10] FARJANA, T.; TUNO, N. Effect of body size on multiple blood feeding and egg retention of Aedes aegypti (L.) and Aedes albopictus (Skuse) (Diptera: Culicidae). Medical Entomology and Zoology 63: 123-131. 2012.

FARJANA, T.; TUNO, N. Multiple Blood Feeding and Host-Seeking Behavior in Aedes aegypti and Aedes albopictus (Diptera: Culicidae). Journal of Medical Entomology 50: 838-846. 2013.

FAY, R. W.; ELIASON, D. A. A preferred oviposition site as a surveillance method for Aedes aegypti. Mosquito News 26: 531-535. 1966.

FERREIRA, P. G.; TESLA, B., et al. Temperature Dramatically Shapes Mosquito Gene Expression With Consequences for Mosquito-Zika Virus Interactions. Frontiers in Microbiology 11. 2020.

FORATTINI, O. P. Principais mosquitos de importância sanitária no Brasil. Cadernos de Saúde Pública 11: 157-158. 1995.

FORATTINI, O. P. Culicidologia médica: Identificação, Biologia e Epidemiologia. In: Edusp (Ed.) II.2nd ed. São Paulo, 864p. 2002.

FRITZELL, C.; ROUSSET, D., et al.Current challenges and implications for dengue, chikungunya and Zika seroprevalence studies worldwide: A scoping review. PLOS Neglected Tropical Diseases 12: e0006533. 2018.

GONÇALVES, T. DAS C. Análise da transcrição dos genes CYP6N12 e Rdl em Aedes aegypti 
Linnaeus, 1762 (Diptera: Culicidae) em resposta à intoxicação pelo biolarvicida espinosade. 72p. 2019.

GOUVEIA, G. R.; FERREIRA, S. C., et al. Comparação de três protocolos distintos para extração de RNA de amostras fixadas em formalina e emblocadas em parafina. Jornal Brasileiro de Patologia e Medicina Laboratorial 47: 649-654. 2011.

KÖHRER, K.; DOMDEY, H. Preparation of high molecular weight RNA. Methods in enzymology 194: 398-405. 1991.

LIMA-CAMARA, T. N. Emerging arboviruses and public health challenges in Brazil. Revista de Saúde Pública 50: 1-7. 2016.

LUZ, A. C. DA; PRETTI, I. R.; BATITUCCI, M. D. C. P. Comparison of RNA extraction methods for Passiflora edulis. Revista Brasileira de Fruticultura. 38: 226-232. 2016.

MARCONDES, C. B.; XIMENES, M. DE F. F. DE M. Zika virus in Brazil and the danger of infestation by Aedes (Stegomyia) mosquitoes. Revista da Sociedade Brasileira de Medicina Tropical. 49: 4-10. 2015.

MARQUES, G. R. A. M., et al. Água de abastecimento público de consumo humano e oviposição de Aedes aegypti. Revista de Saúde Pública. 47: 579-587. 2013.

NASCIMENTO, L.; MELNYK, A. A química dos pesticidas no meio ambiente e na saúde The chemistry of pesticides in the environment and health. Artigo Revista Mangaio Acadêmico 1: 54-61. 2016.

NASCIMENTO NETO, J. F., et al. Analysis of the transcription of genes encoding heat shock proteins (hsp) in Aedes aegypti Linnaeus, 1762 (Diptera: Culicidae), maintained under climatic conditions provided by the IPCC (Intergovernmental Panel On Climate Change) for the year 2100. Infection, Genetics and Evolution 86: 104626. 2020.

OLIVEIRA DO AMARAL, E.; FELIPE DA SILVA, A., et al. Post-Embryonic Development of Aedes (Stegomyia) aegypti Linnaeus, 1762 at Different Temperatures and $\mathrm{CO}_{2}$ Concentrations, and Their Influences on Hatching and Development of Stabilized Population. In: Life Cycle and Development of Diptera, IntechOpen, p.13. 2020.

OLIVEIRA, S. DE L.; CARVALHO, D. O.; CAPURRO, M. L. Mosquito transgênico: do paper para a realidade. Revista da Biologia 6b: 38-43. 2011.

POOLE-SMITH, B. K.; HEMME, R. R., et al. Comparison of Vector Competence of Aedes mediovittatus and Aedes aegypti for Dengue Virus: Implications for Dengue Control in the Caribbean. PLOS Neglected Tropical Diseases 9: e0003462. 2015.

PRASAD, T. S. K.; MOHANTY, A. K., et al. Integrating transcriptomic and proteomic data for accurate assembly and annotation of genomes. Genome Research 27: 133-144. 2017.

RAMOS JORGE, M., et al. The Yellow Fever Mosquito Aedes aegypti (Linnaeus): The Breeding Sites. tourism. In: Life Cycle and Development of Diptera. 395, Intech0pen, 116-124. 2019. 
RODRIGUES, N. R.; MACEDO, G. E.; MARTINS, I. K., et al. Short-term sleep deprivation with exposure to nocturnal light alters mitochondrial bioenergetics in Drosophila. Free Radical Biology and Medicine 120: 395-406. 2018.

SAÚDE. Monitoramento dos casos de Arboviroses urbanas transmitidas pelo Aedes (dengue, chikungunya e Zika). Boletim Epidemiológico Arboviroses 51: 1-13. 2021.

SAUDE, S. DE V; Em, I. Monitoramento dos casos de arboviroses urbanas causados por vírus transmitidos por Aedes (dengue, chikungunya e zika), semanas epidemiológicas 1 a 53, 2020. 52: 1-31. 2021.

SHARMA, A.; KUMAR, B. V. S.; DASH, S.; SINGH, S.; VERMA, R. Heat shock protein B1 expression is associated with age at sexual maturity in Rhode Island Red and Punjab Red layers under heat stress. International Journal of Biometeorology. 2020.

SIM, C.; HONG, Y. S.; TSETSARKIN, K. A., et al. Anopheles gambiae heat shock protein cognate 70B impedes o'nyong-nyong virus replication. BMC Genomics 8: 231. 2007.

SMITH, C.; BALDWIN, A. H., et al. Effects of Elevated Atmospheric $\mathrm{CO}_{2}$ on Competition Between the Mosquitoes Aedes albopictus and Ae. triseriatus via Changes in Litter Quality and Production. Journal of Medical Entomology 50: 521-532. 2013.

SOUZA, H.M. DE L.; BARRETO, L. R., et al. Tolerance to polycyclic aromatic hydrocarbons (PAHs) by filamentous fungi isolated from contaminated sediment in the Amazon region. Acta Scientiarum - Biological Sciences 39: 481-488. 2017

TERRA, M.R.; SILVA, R.S. DA., et al. Aedes aegypti E as arbovíroses emergentes no brasil Aedes aegypti and emerging arborovers in Brazil. Revista Uningá Review. 30. 2017.

TESLA, B.; DEMAKOVSKY, L. R.; MORDECAI, E. A., et al. Temperature drives Zika virus transmission: evidence from empirical and mathematical models. Proceedings of the Royal Society B: Biological Sciences 285: 20180795. 2018.

TOZAT0, C. de C. Aplicação de conjugado de microesferas de poliestireno para preparo de RNA no diagnóstico da cinomose canina por RT-qPCR. Universidade Estadual Paulista. 2014.

WANG, Y.; GHAFFARI, N., et al. Evaluation of the coverage and depth of transcriptome by RNA-Seq in chickens. BMC Bioinformatics 12: S5. 2011.

WILKE, A. B. B.; CARVAJAL, A.; MEDINA, J., et al. Assessment of the effectiveness of BGSentinel traps baited with $\mathrm{CO}_{2}$ and BG-Lure for the surveillance of vector mosquitoes in Miami-Dade County, Florida. PLoS ONE 14: 1-15. 2019.

WILL, T.; SCHMIDTBERG, H.; SKALJAC, M.; VILCINSKAS, A. Heat shock protein 83 plays pleiotropic roles in embryogenesis, longevity, and fecundity of the pea aphid Acyrthosiphon pisum. Development Genes and Evolution 227: 1-9. 2017.

ZARA, A.L. DE S. A.; MARIA DOS SANTOS, S., et al. Estratégias de controle do Aedes aegypti: uma revisão. Epidemiologia e Serviços de Saúde 25: 1-2. 2016. 
